Universidade de São Paulo

Faculdade de Filosofia, Letras e Ciências Humana

Departamento de Geografia

Programa de Pós-Graduação em Geografia

GEOPOLÍTICA NA FRONTEIRA NORTE DO BRASIL: O PAPEL DAS FORÇAS ARMADAS NAS TRANSFORMAÇÕES SÓCIOESPACIAIS DO ESTADO DE RORAIMA

Altiva Barbosa da Silva

Boa Vista - São Paulo

Junho, 2007 
Universidade de São Paulo

Faculdade de Filosofia Letras e Ciências Humanas

Departamento de Geografia

Programa de Pós-Graduação em Geografia

\title{
GEOPOLÍTICA NA FRONTEIRA NORTE DO BRASIL: O PAPEL DAS FORÇAS ARMADAS NAS TRANSFORMAÇÕES SÓCIO- ESPACIAIS DO ESTADO DE RORAIMA
}

\author{
Altiva Barbosa da Silva
}

Tese apresentada ao Programa de PósGraduação em Geografia Humana da Faculdade de Filosofia, Letras e Ciências Humanas da Universidade de São Paulo, para obtenção do titulo de doutor em Geografia Humana.

Orientador: Prof. Dr. Wanderley Messias da Costa

Boa Vista - São Paulo Junho,2007 
Para meu pai, José Barbosa da Silva (in memoriam)

"Pela oportunidade que tive de realizar um sonho, que sempre foi nosso" 


\section{AGRADECIMENTOS}

Agradeço em particular à minha mãe e à minha irmã Nila, que tão carinhosamente se mantêm presentes em minha vida, apesar de toda distância geográfica que nos separa, bem como a toda a minha família, que também de longe acompanha o meu caminhar.

Agradeço aos grandes amigos que a vida me deu: ao Beto, à Jânia, à Rose, à Cris, ao Christof, à Beth, a Dona Ana, ao Sr. Gil, ao Fernando e às suas famílias.

Aos meus amigos do Departamento de Geografia da USP. Aos grandes mestres que tanto contribuíram na minha formação intelectual, na maneira de ver e interagir com o mundo, em especial ao professor Wanderley, por depositar sua confiança no meu trabalho, por ter-me apoiado e contribuído todas as vezes de que necessitei. E, aos funcionários desta instituição, cujo apoio tem sido fundamental em todas as etapas da pesquisa. Agradeço ao Orlando, ao Marcos, à Cida, à Jurema, à Ana, ao Tião...

Aos novos amigos: à Lói, à Dedé, ao Paulo, ao Veras, ao Marcos, à Paula, à Gersa, ao Stélio, à Goreth, à Niki, à Aline, ao Carlos, à Audrey, ao Jaime (...)

À Universidade Federal de Roraima que tem me proporcionado um espaço de debate e intercâmbio. Aos funcionários desta instituição por todo apoio que sempre nos dedicam. Em especial, aos professores do Centro de Ciências Humanas, cujos debates e documentos cedidos me ajudaram muito nesta caminhada. Ao Jaci, ao Nélvio, ao Cléber, à Maria Luiza, à Rogélia, à Kátia, à Carla (...). Ao professor Fábio Almeida e ao Richarliton que muito contribuíram através, respectivamente, da revisão e formatação final do trabalho. E, e a todos os meus alunos que também contribuíram com este debate.

Sou muito grata a todos os entrevistados que se dispuseram a compartilhar a experiência obtida em Roraima e que me cederam documentos e abriram novas perspectivas para esta investigação. Em especial, ao Sg. Castro, ao Cel. Seabra, ao Sr. Livânio, ao Davi Yanomami, ao Maurice Tomioka, ao Sg. Lewisk, ao Cel Fontoura; a todos os civis e militares que me ajudaram nesta pesquisa, e que acreditam num trabalho compartilhado.

Ao Taimã, que é o maior presente que Deus me deu, quem mais torceu para que eu concluísse esta tese, que lhe privou de minha participação em tantos eventos únicos em sua infância. Que o meu esforço lhe sirva de estímulo para nunca abandonar seus ideais. 


\section{RESUMO}

Esta pesquisa analisa os recentes processos de caráter geopolítico que vêm ocorrendo na Amazônia brasileira e confere especial ao papel desempenhado pelas Forças Armadas nas áreas fronteiriças desta região. A argumentação que desenvolvemos volta seu foco para a atuação dos Pelotões Especiais de Fronteira, no contexto sócioeconômico e político de Roraima, no período que vai desde sua implantação do Território Federal, acontecida nos anos de 1940, até os dias atuais.

Para que possamos traçar a contento esse panorama, investigamos mais detidamente as políticas de governo estabelecidas após os anos 60 , quando as unidades militares assumiram papel central na transformação deste território, definido como estratégico para os eventos que estavam ocorrendo no País e no subcontinente sul americano.

Assim, tivemos que dar ênfase a alguns fatos e eventos importantes para podermos demonstrar o papel específico que as Forças Armadas, notadamente, o Exército e a Aeronáutica, desempenharam no cotidiano de Roraima, através de suas ações, de seu "ethos", e da atuação da administração direta dos oficiais da Aeronáutica, durante o regime militar.

Os resultados que obtivemos nos permitiram constatar que a organização do espaço social de Roraima continua a ser pensada e concebida a milhas de distância deste espaço. Prova disso é que as Forças Armadas ainda desempenham importante papel no Estado, apesar do seu distanciamento corporativo e do antagonismo em conciliar a hierarquia militar com a "gestão participativa", base do discurso hegemônico, desde os anos 90 .

A investigação nos permitiu concluir que as Forças Armadas ainda desfrutam de status e desempenham um papel ainda muito importante na Amazônia. Pode-se a isso acrescentar que, no momento, elas protagonizam um novo e importante papel, que se consubstancia por meio dos Pelotões Especiais de Fronteira/PEF, bem como de outros mecanismos, recentes implantados em áreas importantes à soberania do País, agora também tornadas relevantes pelos seus aspectos ambientais, étnicos e culturais.

Palavras-chave: Amazônia, Roraima, Pelotões Especiais de Fronteira/PEF, Geopolítica, Exército. 


\begin{abstract}
This research analyses recent processes of political feature that are happening in the Brazilian Amazon, with emphasis to the role of the Armed Forces in border areas of this region. Our argumentation focused on the performance of the Border Special Platoons, in the socio-economic and political context of Roraima, since the foundation of the Federal Territory, in the 1940s.

We concentrated, however, on policies established after the 1960s, when military unities start to play central role in the transformation of this territory, defined as strategic for events that were happening in the country and in the South American subcontinent.

We retrieved some facts and events in order to demonstrate the specific role that the Armed Forces, especially, the Army and the Air Force have played in Roraima everyday life, through their activities, their "ethos", and the direct administration of officials belonging to the Air Force, during the military regime.

We found out that the organization of the Roraima social space continues to be conceived from miles away of this space, so much so that the Armed Forces still play important role in the Roraima State, despite its corporative distance, and the antagonism in conciliating the military hierarchy, with the participative administration, since the 1990s.

We concluded that the Armed Forces, with a widened role in the Amazon, represent a new moment through Border Special Platoons/BSP and others recent mechanisms, in important areas to the sovereignty of the country, now also relevant for their environmental, ethnic and cultural aspects.
\end{abstract}

Key-words: Amazon, Roraima, Border Special Platoons/BEP, Geopolitics, Army. 


\section{LISTA DAS ILUSTRAÇÕES}

\section{Tabelas}

1 - Pop. por município em Roraima 2005/2006 42

2 - Pop. Total e percentual - $2000 \quad 43$

3 - Emancipação política dos municípios 44

4 - Governadores de Roraima 49

5 - Processo migratório para Roraima, 1996, 98, 99, 2000

6 - Crescimento Demográfico em Roraima no séc. XX 55

7- Participação dos setores econômicos no PIB de Roraima 56

8 - Pop. Urbana e Rural em Roraima 1950/2000 57

9 - Áreas de Influência da Ouro Verde Agrosilvopastoril 63

\section{Gráfico}

$\begin{array}{ll}1-\text { Recursos recebidos do PCN } & 70\end{array}$

\section{Mapas}

1 - Municípios e Rodovias - Roraima 39

2 - Áreas institucionais de Roraima 53

\section{Figuras}

1 - Eixos de integração na América do Sul 36

2 - Posição estratégica de Roraima 37

3 - Distritos Sanitários Yanomami e Yequana 41

4 - Sistema de energia em Roraima 60

5 - Calha Norte $\quad 68$

6 - SIVAM/SIPAM 81

$\begin{array}{ll}7 \text { - Os PEFs da Amazônia } & 115\end{array}$

8 - PEFs de Roraima 154 


\section{Fotos}

1 - Aeronove Búfalo próxima ao PEF de Auaris 129

2 - Aeronave ALX Supertucano 130



4 - Avenida Ene Garcês - Boa Vista 143

5- Aeroporto Internacional de Boa Vista 145

6 - Ginásio de Esportes “Totozão” 145

7 - Norte Shopping Hotel e residências militares 146

8 - 5ํㅜㄹotão Especial de Fronteira - 5을 BIS - Auaris 152

9 - Visita de alunos Yekana ao PEF de Auaris 161

10 - Comemoração do 7 de setembro - 5 PEF 164

11 - Torre do SIVAM em Auaris 166 


\section{LISTA DE SIGLAS}

ACIR - Associação Comercial Industrial de Roraima

ACPIR - Associação Cultural dos Povos de Roraima

ALID/CIRR - Aliança para a Integração e Desenvolvimento das Comunidades Indígenas

BASA - Banco da Amazônia

BEC - Batalhão de Engenharia e Construção

BIRD - Banco Mundial

BIS - Brigada de Infantaria de Selva

BNDES - Banco Nacional de Desenvolvimento Econômico e Social

C Mil A - Comandos Militares de Área

CADR - Comissão da Amazônia e do Desenvolvimento Regional

CFR - Comando de Fronteira de Roraima

CIMI - Conselho Indigenista Missionário

CIR - Conselho Indígena de Roraima

DLIS - Desenvolvimento Local, Integrado e Sustentável (ou PDLIS)

ECEME - Escola de Comando e Estado Maior do Exército

EME - Estado Maior do Exército

ENID - Eixos Nacionais de Integração e Desenvolvimento

ESG - Escola Superior de Guerra

FA - Forças Armadas

FAB - Força Aérea Brasileira

FECOR - Federação do Comércio do Estado de Roraima

FGV - Fundação Getúlio Vargas

FNO - Fundo Constitucional do Norte

FUNASA- Fundação Nacional de Saúde

GTA - Grupo de Trabalho Amazônico

IAG - International Advisory Group

IBAMA - Instituto Brasileiro do Meio Ambiente e dos Recursos Naturais Renováveis

IBGE - Instituto Brasileiro de Geografia e Estatística

IDH - Índice de Desenvolvimento Humano

IEA - Instituto de Estudos Avançados, Universidade de São Paulo

IGEO - Instituto de Geociências da UFRR

INCRA - Instituto Nacional de Colonização e Reforma Agrária

INPE - Instituto Nacional de Pesquisas Espaciais

IPEA - Instituto de pesquisas Econômicas Aplicadas

ISA - Instituto Sócio Ambiental

ITERAIMA - Instituto de Terras do Estado de Roraima

MCT - Ministério da Ciência e Tecnologia

MD - Ministério da Defesa

MDA - Ministério do Desenvolvimento Agrário

MIN - Ministério da Integração Nacional

MMA - Ministério do Meio Ambiente

MPO - Ministério do Planejamento e Orçamento

NAEA - Núcleo de Altos Estudos da Amazônia. Universidade Federal do Pará

OIT - Organização Internacional do Trabalho

OM - Organização Militar

ONG - Organização não-governamental

OPIR - Organização dos Professores Indígenas de Roraima

OSCIP - Organizações da Sociedade Civil de Interesse Público 
PCN - Programa Calha Norte

PD/A - Projetos Demonstrativos tipo A (PPG-7)

PDN - Política de Defesa Nacional

PDLIS - Planos de Desenvolvimento Local Integrado e Sustentável

PGAEB - Política de Gestão Ambiental do Exército

PIN - Programa de Integração Nacional

PND - Plano Nacional de Desenvolvimento

PNMA - Programa Nacional de Meio Ambiente

PPA - Plano PluriAnual

PPG-7 - Programa Piloto de Proteção das Florestas Tropicais do Brasil

PPTAL - Projeto Terras Indígenas da Amazônia Legal

SCA - Secretaria de Coordenação da Amazônia

SDS - Secretaria de Desenvolvimento Sustentável

SIPAM - Sistema de Proteção da Amazônia

SIVAM - Sistema de Vigilância da Amazônia

SODIUR - Sociedade de Defesa dos Índios Unidos do Norte de Roraima

SPI - Serviço de Proteção ao Índio

SPVEA - Superintendência do Plano de Valorização Econômica da Amazônia

SUDAM - Superintendência de Desenvolvimento da Amazônia

SUFRAMA - Superintendência da Zona Franca de Manaus

TCA - Tratado de Cooperação Amazônica

TF - Território Federal

UnB - Universidade de Brasília

ZEE - Zoneamento Econômico-ecológico

UFRR- Universidade Federal de Roraima 
CAPÍTULO I - BASES TEÓRICO-METODOLÓGICAS DA PESQUISA

$\begin{array}{lll}\text { I.1 Caracterização geral da metodologia } & 18\end{array}$

$\begin{array}{lll}\text { I.1.1 As principais fontes e referências utilizadas na pesquisa } & 21\end{array}$

I.2 Geografia Política e Geopolítica como bases teóricas da pesquisa 23

I.3 Dialogando com as Ciências Sociais 29

CAPÍTULO II - ESPAÇO E PODER NA AMAZÔNIA

II.1 Caracterização de um espaço de singularidades 36

II.2 Recentes processos de estruturação do Estado de Roraima 52

II.3 Os desdobramentos de programas e projetos protagonizados por militares $\quad 67$

II.4 A metamorfose do Programa Calha Norte 68

II.5 As tecnologias do SIVAM/SIPAM conectando os espaços 78

CAPÍTULO III - UMA INTERPRETAÇÃO DO SIGNIFICADO DAS FORÇAS ARMADAS

III.1 A tradição militar no Brasil 91

III.2 De fortes e colônias militares à criação do CMA 105

CAPÍTULO IV - ATUAÇÃO DAS FORÇAS ARMADAS EM RORAIMA

IV.1 O CMA e a atuação das Forças Armadas em Roraima 114

IV.2 Estratégias de ocupação e modernização no vale do rio Branco 133

$\begin{array}{lll}\text { IV.3 A colonização militar na última fronteira } & 137\end{array}$

IV.4 O "Fausto Militar" em Roraima $\quad 143$

IV.5 A criação de unidades militares num novo contexto democrático 148

$\begin{array}{lll}\text { IV.6 A função dos pelotões de fronteira } & 158\end{array}$

$\begin{array}{ll}\text { CONCLUSÃO } & 168\end{array}$

$\begin{array}{ll}\text { REFERÊNCIAS BIBLIOGRÁFICAS } & 173\end{array}$

$\begin{array}{ll}\text { ANEXOS } & 182\end{array}$

1 - PORTARIA № 020 - EME / 2 DE ABRIL DE 2003

2 - DECRETO № 4.412 - 7 DE OUTUBRO DE 2002 


\section{INTRODUÇÃO}

A trajetória desta pesquisa inicia-se com minha vivência na Amazônia, que começou no ano de 1995. Ao todo, esse lapso de tempo perfaz mais de uma década de complexas transformações presenciadas por mim. Em algumas delas, tive participação mais ativa, como aconteceu quando participei do desenvolvimento de projetos sócioambientais e com o trabalho de docência que realizo desde julho/2004 junto à Universidade Federal de Roraima-UFRR.

A escolha do tema a ser pesquisado não foi fácil, uma vez que enquanto a realidade sempre se mostra em seus vários ângulos e contradições, a investigação acadêmica exige um recorte específico do todo. Além disso, tenho consciência de que nem sempre se pode estabelecer uma linha de coerência em relação aos fatos e processos observados.

Posso afirmar que muito contribuiu para minha escolha a participação em vários eventos ao longo desses anos. Durante esse tempo, fui levantando dados que, a partir de 2003, já apontavam para a existência de uma nova realidade na esfera da segurança e defesa da Amazônia.

Somente, em meados de 2004, quando passei a manter uma vivência direta e intensa no Estado de Roraima, minha pesquisa pôde ser mais bem definida. Em vista dos primeiros resultados alcançados, nos voltamos para estudar a nova geopolítica da Amazônia, dando especial destaque a uma porção do seu território, qual seja, ao estado de Roraima.

A partir do momento em que fui podendo fazer uma leitura mais atenta e rigorosa dos fatos cotidianos de Roraima, tive a indicação de que as Forças Armadas ainda desempenham um papel muito importante na geopolítica local, apesar de serem bem poucos os trabalhos científicos que se voltam para estudar este tema.

Com as primeiras visitas ao principal objeto da pesquisa, o Exército, certifiquei-me de que, apesar de toda receptividade que me foi dedicada, não era possível levantar os dados que me interessavam num curto espaço de tempo, uma vez que meu interesse era o de fazer uma análise da atuação das Forças Armadas, Exército e Aeronáutica, no Estado de Roraima, ou por outra, compreender o papel político desses agentes locais para a estruturação espacial de Roraima. 
A realização da pesquisa exigia a existência e a disponibilização de documentos para consulta pública de arquivos nessas instituições, as quais deveriam conter um grau de informação mais abrangente do que pude perceber nas visitas que efetuei. Diante disso, me restava a possibilidade de trabalhar com a "história oral", ou seja, de trabalhar a partir da memória e da experiência de muitos roraimenses e/ou migrantes militares, a exemplo do próprio governador: o Brigadeiro Ottomar Pinto, que veio designado pela Aeronáutica, na década de 70, e ainda hoje permanece no "comando" de Roraima.

Como eu pretendia traçar um panorama minucioso, que abrangesse desde a instalação dos Pelotões Especiais de Fronteira-PEFs em Roraima, passando pelas alterações sócio-espaciais que foram acontecendo em decorrência dessas instalações militares, a alternativa que me pareceu mais viável foi empreender a análise a partir de fatos narrados, além dos documentos existentes a que pudesse ter acesso.

Mas esse também foi um problema de difícil resolução, pois a maioria dos habitantes chegaram a Roraima após a década de 1980. Em se tratando dos militares da ativa, com raras exceções, permanecem na localidade por mais de cinco anos, em vista das sucessivas transferências de trabalho de uma para outra unidade.

Em razão disso, apesar do meu grande interesse por essa abordagem metodológica, o tempo, os recursos e as peculiaridades expostas tornaram este foco que era central no início da pesquisa - secundário. Não obstante, esses dados ainda estão sendo trabalhados em pesquisa de campo com alunos e outros pesquisadores e necessitam ainda de amadurecimento para que possam ser trazidos a um debate mais amplo.

Um outro fator importante é o grau de confiabilidade das informações adquiridas. Em parte, porque os entrevistados não falam tão abertamente da "vida da caserna", como falariam de outros temas. Por outro lado, o nível de informação mais complexa fica restrita a um oficialato mambembe, que não cria raízes e, por isto mesmo, não acompanha o desenrolar da história no Estado. Os diversos tipos de relatórios produzidos também são apresentados diretamente aos comandos, sediados a milhas de distância de Roraima.

Muitos dos alunos com os quais trabalho na UFRR são militares. Isso possibilitou o cruzamento de alguns dados obtidos e o estabelecimento de alguns debates ocorridos em diferentes ocasiões. Mas, como é sabido, para alguns temas, a "aproximação objetual" é bem mais complexa. Por causa disso, tive que redefinir a metodologia da pesquisa para bases mais sólidas e decidi fixar-me em trabalhos e publicações que versam sobre 
segurança e defesa. Esta temática tem adquirido realce na academia, nos últimos anos, notadamente nos cursos de Relações Internacionais e de Ciências Políticas.

Isso permitiu fazer um contraponto mais freqüente com os dados adquiridos em campo. Mesmo assim, há de se considerar as dificuldades de acesso às informações, concentradas em centros distantes como Manaus, Brasília, Rio de Janeiro e outras capitais, que possuem centros de estudos estratégicos.

A centralização de dados é um fator crucial para quem deseja fazer pesquisa in loco sobre a atuação das Forças Armadas. Esta dificuldade não existe por acaso: é herança do Regime Militar, que deixou muitas seqüelas, dentre elas o afastamento dos pesquisadores e da academia, em geral, dos assuntos militares. Isso acarreta que hoje temos uma quantidade de pesquisa muito aquém das necessidades, em relação a este setor. A maioria delas é feita por oficiais da Escola do Comando e Estado Maior do Exército; outras são publicadas por outros militares, em periódicos especializados do setor.

Pode-se dizer que houve um isolamento das idéias e que, apesar do papel tão presente das Forças Armadas no cotidiano da população amazônica, não há registros sistemáticos dessas experiências. Nos antigos Territórios Federais, a presença militar deixou marcas nítidas nas paisagens locais e serviu para estruturar praticamente toda a rede de infra-estrutura existente até hoje, e até mesmo, a rede social e de poder, que se estabeleceu nesses territórios.

A carência da "visão civil" deste importante setor para o organograma político regional da Amazônia é um dos fatores que dificultam uma efetiva parceria para a solução dos problemas de segurança e defesa na região. Não obstante esse estado de coisas, desde meados da década de 80, com a vigência do Regime Democrático, cabe ao poder civil conduzir as políticas em todos os âmbitos da sociedade. Isso torna premente a necessidade de uma maior compreensão deste universo militar, pelo que representou e representa no cotidiano dessas localidades que ficam "de costas" para o Brasil.

Assim, partimos de um levantamento das principais obras que versam sobre o tema, junto a alguns órgãos, sediados em Roraima, Brasília, Manaus e São Paulo. $O$

\footnotetext{
Embora muito pouco conhecidas, há muitas obras escritas por militares, a partir de suas experiências em áreas de fronteiras, mas este material, acaba se constituindo em visões muito interna ao contexto militar, uma vez que não são debatidas, e confrontadas com outras obras e pesquisas, desenvolvidas no âmbito científico mais amplo.
} 
intuito era o de compreender os elos com a economia, a política e a sociedade roraimense. $\mathrm{O}$ fato de residir em Boa Vista tem facilitado 0 acesso às informações, tanto em relação aos contatos com atores locais, quanto em relação ao acesso a teses e publicações, que não são encontradas nas bibliotecas do Estado.

O dado novo é que uma intelectualidade nascente tem produzido obras de excelente qualidade. A maior parte deste novo grupo compõe o quadro de professores e pesquisadores da UFRR. Mas, isto vem ocorrendo, praticamente, a partir deste milênio, até porque a UFRR apenas foi inaugurada em 1989, com um quadro muito pequeno de mestres e doutores, à época.

Por outro viés, os resultados colhidos por meio das entrevistas, das leituras e da vivência em Roraima apontaram para a relevância e a centralidade do elemento étnico para a compreensão da geopolítica local. Isso permite entender os principais desafios que estão postos para o governo local, na medida em que falar de defesa e segurança neste Estado pressupõe entender os conflitos de interesses, que são marcados por uma cisão básica entre dois universos: o indígena e o "ocidental capitalista", apresentados como par antagônico.

Quando se estuda Roraima com foco nas Forças Armadas, que atuam diretamente em áreas indígenas, a questão da etnicidade torna-se absolutamente central para a análise, ao contrário do que se observa na maioria dos Estados brasileiros, onde o elemento étnico fica submerso no regional.

Recentes estudos têm demonstrado que a consciência política dos indígenas está remodelando sua atuação junto ao Estado. Gradativamente os grupos indígenas roraimenses têm assumido sua condição étnica, com demandas específicas, que representam um grande desafio para a gestão política que permeia todas as áreas, inclusive as de segurança e defesa.

Os conflitos de interesse e as diferentes percepções dos processos em curso, segundo a versão dos diferentes atores sociais, são esclarecedores do desafio posto ao Estado e à União.

Para dar conta disso, foram feitas entrevistas com alguns atores e foram recolhidos dados através de visitas de campo. Utilizamos, sobremaneira, as fontes mais recentes de informações, provenientes de jornais, revistas, encontros, seminários e outros documentos de circulação restrita. Não foi possível, porém, formatar todo este material, 
que formaria um capítulo adicional nesta tese. No entanto, nossa compreensão da importância deste objeto da pesquisa nos obriga a fazer estas considerações iniciais, uma vez que cremos que, nas entrelinhas da pesquisa, este viés acaba aparecendo.

Chegamos, assim, a um formato da tese que se inicia com uma discussão sobre a fundamentação teórico-metodológica do tema, cuja base se encontra na Geografia, na Geopolítica, e nos ramos das Ciências Sociais mais afins, como as Ciências Políticas.

O capítulo II tem dois eixos de discussão: a) caracterização de aspectos sociais, econômicos e políticos de Roraima, com destaque para os principais eventos históricos que interferem na nossa análise, e para os recentes processos de estruturação deste território; b) desdobramentos de programas e projetos protagonizados por militares na Amazônia e o significado dos mesmos em Roraima.

No terceiro capítulo desenvolvemos nosso tema também em dois eixos de discussão. No primeiro, procuramos mostrar o percurso militar no País, desde a tradição portuguesa, até a constituição da atual Forças Armadas. Sabedora de que o assunto é pouco debatido na Geografia, ainda que pesquisas desta natureza sejam bastante comum nas Ciências Políticas, fui-me aproximando desse campo. No segundo eixo, completamos o entendimento desta questão, abordando o surgimento das bases militares na Amazônia.

No quarto capítulo, analisamos o fenômeno militar em Roraima desde a instalação das primeiras unidades de fronteira. Procuramos mostrar a importância do fenômeno para a transformação da paisagem local e adentramos um pouco na atuação e vivência dos militares nas áreas dos Pelotões Especiais de Fronteira, para entender que significado possuem no contexto local e mais amplo.

Na conclusão apontamos os elementos considerados centrais na nova geopolítica amazônica, da qual Roraima é parte importante. Nesse passo, damos destaque aos novos signos presentes no discurso ambiental, agora apropriado pelo setor militar como legítimo defensor da causa ambiental, e quiçá étnica, se o processo de aproximação ${ }^{2}$ com essas comunidades, já iniciado, resultar numa incorporação mais sólida dentro da doutrina militar e se o intercâmbio entre os dois pólos for assentado em base consensual. Vale ressaltar sobre as questões ambientais que se pode ler em faixa imensa afixada em

2 Uma aproximação, porém, diferente, do que ocorreu ao longo dos séculos no país, cuja literatura é sobejamente conhecida. 
frente ao prédio do Ibama/Boa Vista ${ }^{3}$ : "defender o meio ambiente é questão de soberania nacional". Como se percebe, o enunciado da faixa é indicial desse processo.

3 Afixada por grevistas deste órgão (desde maio/2007), com o intuito de destacar a importância do meio ambiente para o país. 


\section{CAPÍTULO I}

\section{BASES TEÓRICO-METODOLÓGICAS DA PESQUISA}

\section{I.1 Caracterização geral da metodologia}

A base teórico-metodológica que norteia esta pesquisa está fortemente relacionada à minha vivência acadêmica, iniciada junto ao Departamento de Geografia da Faculdade de Filosofia, Ciências e Letras da USP em 1984. A Geografia desta década tem forte inspiração no movimento intitulado "Geografia Crítica", consolidado no Brasil por ocasião do Congresso AGB, ocorrido em Fortaleza, no ano de 1978, com inspiração no pensamento marxista.

Na sua essência, esta vertente do pensamento geográfico compreende o espaço como "a base material da sociedade", sociedade esta que se transforma a todo instante e que agrega valores e significados ao território, e, ao mesmo tempo, recebe marcas herdadas de passados, com graus variáveis de interferência no presente. Na contínua construção que os geógrafos desta tendência fazem dos espaços sociais, o processo contraditório permeia as relações que se dão entre agentes e instituições, numa teia complexa de significados, na qual "a realidade" é sempre mais dinâmica do que a apreensão momentânea que temos dela.

Nessa abordagem, a complexidade social do espaço somente pode ser apreendida nas suas mediações básicas: sócio-econômicas, políticas, étnicas, culturais e religiosas. Considera-se também que a totalidade dos fenômenos dá-se através de uma dialética entre o todo e parte, o que nos ajuda a situar os fenômenos de escala local presentes no estado de Roraima e que constituem a nossa base de investigação, bem como aqueles que se dão em outras escalas: sejam regionais, nacionais ou globais, e que mantém estreita relação entre si.

O privilégio da formação em Geografia também se apresenta no momento em que, para explicar o real, um grande escopo de várias ciências é requisitado. A Geografia, mais que outros ramos da ciência, opera com elementos sociais e da natureza com relativa "familiaridade" e, à priori, põe acento no aspecto multifacetado do conhecimento.

No caso desta pesquisa, foi decisiva a formação em Ciências Humanas, pois permitiu desde o início, buscar nas "ciências de contato" os conceitos e as 
fundamentações teórico-epistemológicas condizentes com meu objeto de pesquisa e de que a Geografia, em si, não dispunha.

Partindo do instrumental teórico-metodológico da Geografia, detemo-nos no campo da Geografia Política e de sua versão mais pragmática, que é a Geopolítica ${ }^{4}$, justamente por entender que as políticas centralizadoras exercidas no Estado de Roraima até os anos 1980 tiveram (e têm) como pilar central a recorrência ao espaço físico, objeto de tantas reflexões na Geopolítica.

Após uma década, o presente discurso ainda mantém este foco, só que num contexto diferenciado, onde concorrem vários atores, tão ou mais significativos que o Estado (governos estadual e federal). Anteriormente, o controle na região Amazônia, como um todo, era explicado pela necessidade de se preencher o "vazio demográfico"; de integrar a região aos pólos dinâmicos do País; bem como pela "cobiça internacional" por essa área, ainda "intocada", segundo o mito ocidental moderno.

Hoje a Geopolítica de Roraima está mais presente na busca de inserção nos novos cenários estratégicos em nível nacional e global, com destaque para o campo da proteção, da vigilância e do monitoramento ambiental da Amazônia Setentrional. Além disso, contam também os aspectos básicos de segurança e defesa de uma área potencialmente estratégica para o comércio e o intercâmbio geral com países vizinhos, sobretudo pela saída para o Caribe, e também pela possibilidade de conflitos e ilícitos que ocorrem ou podem ocorrer em áreas de fronteira.

Ainda que situados em momento histórico específico, os debates clássicos da Geopolítica, relativos aos conceitos de território, povo, nação, fronteira, Estado, posição, situação, centralidade, cultura, etnia, progresso, dentre outros, fornecem um parâmetro para o desafio de pensar essas questões na "ultima fronteira" do planeta.

Quando os discursos geopolíticos foram produzidos, do final do século XIX a meados do século XX, legitimaram o "domínio da natureza", que se processou impiedosamente sobre as culturas, os povos, as nações, os Estados, e definiram, por assim dizer, as hegemonias posteriores. A idéia de progresso e de culto ao

\footnotetext{
4 Existe uma ampla literatura a respeito do assunto, no Brasil a obra de COSTA,W. (1992), sintetiza os principais eventos, idéias, obras, pontuando seus protagonistas, deste o final do século XIX. Também, MORAES,A.C.R. (1996); CASTRO, T. (1986), MIYAMOTO, S. (1981), dentre outros participam deste debate. Utilizaremos, preferencialmente, o conceito: Geopolítica, compreendido na dimensão proposta no artigo de BECKER, B. (1988): A Geografia e o resgate da Geopolítica. Resta salientar, que nossa dissertação de mestrado, avaliou o uso do conceito na Alemanha: BARBOSA,A. (1996).
} 
empreendedorismo das "raças e culturas superiores" legitimou toda forma de uso e abuso que se processou no "mundo civilizado".

Este debate é mais presente no campo da Sociologia e da Antropologia e é retomado nesta pesquisa sempre que se refere ao modo como se processou a ocupação da Amazônia. É nesse contexto que vêm à tona as análises sobre o processo de ocupação promovido pela população branca, em Roraima.

Embora o enfoque de nosso trabalho não seja a questão étnica de Roraima, este tema tangencia nossa abordagem, dada a necessidade de considerar as contradições mais amplas que explicam a especificidade deste espaço geográfico. Do contrário, não se pode compreender as políticas para as áreas da saúde, da educação, bem como outras políticas que se referem aos grupos indígenas em Roraima, os quais, oficialmente, perfazem mais de $10 \%{ }^{5}$ da população e assumem cada vez mais um protagonismo local.

Para a interface com estas questões, tomamos como base autores já discutidos na dissertação de mestrado, alguns deles citados na bibliografia deste trabalho, além de outras obras mais recentes e,sobretudo, as teses produzidas por docentes da UFRR e por outros pesquisadores brasileiros e estrangeiros que se debruçaram sobre o tema. Diretamente relacionado ao nosso foco de pesquisa, destacamos uma importante e recente tese de Antropologia, produzida na UnB por REPETTO, Maxim (2002), atual professor e coordenador pedagógico do Núcleo Insikiran/UFRR.

Por fim, chamou atenção uma dissertação de mestrado em Direito da UFSC, escrita por MONTANARI JUNIOR, Isaias (2005), professor de Direito/UFRR; que mantém uma importante discussão relativa à demarcação de terras indígenas sob o enfoque da defesa nacional.

Enfim, há ainda um universo de idéias muito recentes que estão sendo debatidas, e nos prova que o caminho a trilhar na busca da interpretação da realidade roraimense esta apenas começando.

\footnotetext{
$5 \quad$ Na última contagem feita pelo IBGE, em maio/2007, Roraima possuía um total de 403.344 habitantes hab. Dados recentes (2005/2006) dos Distritos Sanitários Indígenas, apontam uma população, aproximada de 48.000 indígenas. Neste total, não estão inseridos os indígenas que vivem na cidade, cálculo difícil de se fazer pois muitos indígenas não se reconhecem como tal, outros, estão assumindo cada vez mais a identidade indígena, em vista dos recentes processos afirmativos dessas etnias. Embora não tenhamos conseguido os dados suficientes para concluir a análise, através dos projetos e recursos destinados à assistência a esses grupos, tem-se a indicação que esta população seja bem mais representativa do que aparece nas estatísticas oficiais.
} 


\section{I.1.1 As principais fontes e referências utilizadas na pesquisa}

Um dos grandes problemas apontados pelos que vivem e pesquisam em Roraima é a ausência e a precariedade das fontes, uma vez que a maioria delas não está catalogada e nem está disponível em meio digital. Ainda está em vias de implementação um sistema interligado de bibliotecas, no Estado, em razão de que os municípios são, na maioria, recentes, e em estágio de estruturação. Excetuando-se Boa Vista, que concentra mais de $60 \%$ da população do Estado e praticamente quase todos os recursos científicos locais, restam somente alguns espaços alternativos para pesquisa ${ }^{6}$.

No entanto, há importantes trabalhos dispersos que fazem análises mais amplas sobre a Amazônia e alguns materiais produzidos para o planejamento de políticas públicas locais. A obra intitulada Síntese da Bibliografia sobre Roraima (IMBRÓZIO, 2000), dá uma idéia da produção científica existente até esse ano.

Recentemente, vem ocorrendo um grande empenho no sentido de recuperar a memória, ainda viva, existente em Roraima, a respeito de uma época que deixou marcas importantes em toda a paisagem do Estado. Um dessas formas tem sido a produção de documentários produzidos por alunos do Departamento de Comunicação da UFRR ${ }^{7}$, a partir da narração de antigos moradores, que aqui residem desde os anos 40 , quando ainda Território; além de outras pesquisas em história oral, também iniciadas, recentemente, pelas Ciências Sociais da UFRR.

Dentre as pesquisas de pós-graduação produzidas recentemente, a maioria foi escrita após o ano de 2000 e têm sido de extrema relevância, dentre as quais posso citar a dos professores da UFRR: SANTOS, Nélvio P.D. (2004) GUILHERME Jaci (2002).; FRANLIN, Cléber B. (1996); e, OLIVEIRA, Reginaldo Gomes (2003), além da tese dos professores: AGOSTINHO, Jaime (2000), e MOURÃO, Gersa (2004), SILVA, Paulo Rogério (2007); colegas do IGEO/UFRR.

Merecem destaque, também, os trabalhos acadêmicos de boa qualidade já desenvolvidos por alunos para obtenção dos títulos de bacharelado e licenciatura; além das pesquisas realizadas por alunos dos cursos de especialização e mestrado da UFRR e

6 É comum, no Estado a busca de fontes, através de pessoas influentes, antigos moradores, que possuem acervos particulares sobre o Estado de Roraima. Exemplo é o ex-conselheiro Amazonas Brasil, que reúne documentos de várias épocas sobre a história local. Neste caso, certamente, cada um junta o que interessa para sua versão da história.

Documentários existentes no Núcleo de Rádio e TV da UFRR, produzidos a partir de 2000. 
de outras universidades existentes em Roraima ${ }^{8}$. Como já referido, estes trabalhos ainda não estão catalogados, de modo que, somente quem toma parte dos mesmos pode agregá-los às suas referências bibliográficas.

Há ainda trabalhos de oficiais da Escola de Comando do Estado Maior do Exército-ECEME, muitas deles disponíveis para consulta pública. Esses documentos são frequentemente citados por pesquisadores das Ciências Políticas e das Relações Internacionais. Neste último campo, também foi criado recentemente, na UFRR, um curso de graduação e um de pós-graduação, em convênio com a UnB, com perspectivas promissoras para o nosso campo de investigação.

Um outro recurso de suma importância foram os artigos publicados em jornais e revistas nacionais e internacionais. Estes merecem atenção especial por se constituírem em informações mais recentes e de grande impacto na sociedade. Entendemos que cenários futuros têm forte relação com os discursos presentes nos meios de comunicação de massa. Além disso, estes meios possuem uma eficácia e uma rapidez sem paralelo, própria da "pós-modernidade"'. A esse respeito, nos alerta Santos que a produção da inteligência planetária"

\begin{abstract}
já não necessita dos antigos trâmites legitimadores do passado. Hoje, as mensagens e os dados chegam aos escritórios e lares diretamente, praticamente sem intermediários. Trata-se além disso, da transmissão imediata de imagens, realizada pela televisão. É fato que fotógrafos e cinegrafistas podem, igualmente, agir como atores, interpretando, a seu modo, os acontecimentos, com a escolha do ângulo pelo qual os transmitem. (SANTOS, 1996:159).
\end{abstract}

Dando seqüência à discussão relativa às estratégias utilizadas para a compreensão do nosso tema, nas páginas seguintes demonstraremos como a geopolítica produz e reproduz seu atual discurso sobre o território utilizando-se inclusive do discurso midiático, notadamente, no que se refere à Amazônia configurada como o novo Heartland ambiental.

$8 \quad$ Além da UFRR, foi inaugurada a Universidade Estadual de Roraima/UER, em jan/2006. Duas outras faculdades privadas, também já se consolidaram em Boa Vista, e outros cursos particulares, presenciais e à distância, têm sido constituídos, recentemente.

Uma obra central a respeito do tema, e, amplamente difundida, nos círculos acadêmicos e culturais é a obra Condição Pós-Moderna de HARVEY,D. 1992. Outros autores como BERMANN, M., VIRÍLIO, P. são também expoentes da reflexão sobre a velocidade, a fugacidade e a "fragmentalidade" da pós-modernidade. 


\section{I.2 Geografia Política e Geopolítica como bases teóricas da pesquisa}

Durante a pesquisa, sentimos a necessidade de retomar criticamente o passado da Geografia Política, interrompido pelos "descaminhos" da Geopolítica"10, sob a legitimidade da base natural/física do espaço sobre a sociedade. O texto "A Geografia e o resgate da Geopolítica", da professora Bertha BECKER (1988), mostra o enorme desafio que tem a Geografia de resignificar o espaço presente a partir de novas exigências teóricas, ideológicas e sociais. O trabalho enfatiza a necessidade de uma releitura crítica dessa base teórico-epistemológica da Geografia, que não deve ser negligenciada na compreensão da sociedade contemporânea em suas múltiplas e complexas manifestações.

Para esta releitura do passado da Geopolítica, tomamos como base algumas das obras utilizadas na nossa dissertação do mestrado ${ }^{11}$, haja vista que trazem alguns elementos úteis a esta abordagem, sobretudo no que diz respeito às análises críticas produzidas após meados da década de 1980 por autores alemães que se dedicaram ao estudo da Geopolítica no período considerado na referida dissertação.

No Brasil também foram publicadas várias obras importantes para a compreensão do discurso geopolítico, dentre as quais podemos citar COSTA, W. (1992), CASTRO, T. (1986), MIYAMOTO, S. (a partir de 1981). Estas obras traçam um painel amplo dos temas, autores e conceitos adotados pelos geopolíticos brasileiros, deste as primeiras décadas do século XX.

A geopolítica brasileira clássica, de inspiração basicamente militar e forjada num ambiente de rivalidades internacionais e especialmente regionais, desenvolveuse fortemente calcada nas relações do país com os contextos sul-americano e norte-americano, e teve nos Generais $M$. Travassos nos anos trinta, Golbery nos cinquenta e Meira Mattos nos setenta os seus mais conhecidos formuladores. Analistas desse pensamento geopolítico nacional como Becker (1988) e Costa (1992) examinaram o modo pelo qual tais idéias sustentaram concepções de nação, estado e território e o seu desdobramento prático mediante políticas territoriais (internas e externas) operadas no país desde, principalmente, os anos trinta. (FRANKLIN, 1996:12)

\footnotetext{
10 Há uma ampla literatura crítica à Geopolítica, no período posterior à Segunda Guerra Mundial. As principais críticas na Alemanha foram feitas por SCHOLLER,P.; SANDNER,G.; OSSENBRUGGE,J. e ROSSLER,M. Na França, além de uma inumerável bibliografia a respeito do tema, mencionamos uma importante crítica, feita por KLEINSCHMAGER,R., no final do anos 1980. Nos EUA e Brasil também há uma quantidade significativa de críticas aos "descaminhos da Geopolítica". Para uma visão sintética a respeito do tema consultar BARBOSA, A., in SANTOS,M e SOUZA M.A. (1995).
}

$11 \quad$ Vide BARBOSA, Altiva (1996) 
A relação entre a Geografia Política e os projetos políticos expansionistas está presente nas teorias desenvolvidas por autores como R. Kjellén, Alfred Mahan, Halford Mackinder, K. Haushofer e Nicholas Spykman. Todos elaboraram suas teorias no intervalo entre o início do século XX e o final da II Guerra Mundial, período de intensos conflitos entre as principais potências da época.

No Brasil, essa vertente da geopolítica inicia-se com as obras de Everardo Backheuser e de Mário Travassos, na década de 1930. Esses autores receberam forte influência da geopolítica européia ${ }^{12}$, marcada pela grande preocupação com alguns conceitos ligados ao domínio territorial, como "centralidade", "posição", "fronteira", "espaço vital", dentre outros.

Somos da opinião de que a recorrência aos geopolíticos brasileiros pode auxiliar na compreensão dos eventos que se deram e, em alguma medida, ainda permeiam o discurso da elite roraimense conservadora.

Nesse sentido lembra-se a percepção geopolítica do general Meira Mattos, cuja idéia de uma projeção continental do País vinculava-se à sua posição estratégica e pelo fato de possuir fronteiras com quase todos os países sul-americano. Além disso, no que concerne à noção de "centralidade", acreditava que uma efetiva integração do território nacional só seria possível com a mudança de seu pólo central de poder para o Distrito Federal e, conseqüentemente, de toda uma estrutura nodal de estradas que interligasse os vários pontos do território.

COSTA (1992) e MIYAMOTO (1995) elaboraram uma síntese das idéias desenvolvidas pelos geopolíticos mostrando que, ao longo dos anos 40 e 50 do século passado, os temas centrais da geopolítica nacional foram bastante discutidos. Os autores ressaltam que nesse momento, no final dos anos 40, foi criada a Escola Superior de Guerra, locus da discussão estratégica militar do País. O nome desta Escola seria dado em homenagem ao seu teórico mais conhecido: o general Golbery do Couto e Silva

O General Golbery do COUTO E SILVA foi um grande teórico da geopolítica brasileira a partir de 1950. Sua obra de 1967, "Geopolítica do Brasil", representa um paradigma do pensamento militar da época. A grande novidade de sua obra é a reflexão sobre o sistema internacional e as condições de projeção do Brasil neste cenário. "Eminência parda" do regime militar brasileiro, Golbery é o grande mentor das lhe permitiu publicar artigos na Revista de Geopolítica (1926) 
concepções de Segurança Nacional, dando continuidade, ao mesmo tempo, à "teoria do adensamento", com as propostas de ocupação dos "espaços vazios", tão caras ao meio militar $^{13}$.

Mais preocupado com a integração da Amazônia ao resto do País, o General Carlos MEIRA MATTOS, na obra "Uma Geopolítica Pan-Amazônica", faz um relato histórico da colonização amazônica durante os anos de 1960 e 70, destacando a necessidade de articular as redes internas de transportes entre todas as regiões, bem como preparar as conexões com os países da América do Sul. Essa preocupação também se apresenta entre os setores estratégicos do governo e de outros setores, que vêm na ausência de articulação terrestre, ou qualquer outra articulação eficiente em muitas áreas da Amazônia, um motivo de grande preocupação geopolítica, econômica ou social, dependendo do setor que a considera.

As concepções de Mário TRAVASSOS (1947), Golbery do Couto e Silva, Carlos Meira Mattos, e outros, continuam influenciando concepções geopolíticas atuais. É nossa tarefa entender em que medida essas idéias e conceitos têm alguma conexão com a realidade da Amazônia contemporânea, bem como em que devemos avançar em relação a elas.

No momento atual, e no âmbito acadêmico, BECKER $(1997,1998)$, COSTA (1988, 2002), VESENTINI (1986), dentre outros pesquisadores da geopolítica brasileira, ajudamnos a refletir sobre este âmbito, destacando o modo pelo qual o espaço territorial brasileiro foi-se constituindo através de políticas territoriais bem definidas. Os autores mostram como o Estado assume um papel central, durante um longo período de regime centralizador, que se estendeu até início dos anos de 1980, e, posteriormente, como foi incorporando com mais intensidade outros atores.

No final desta década, ocorreram mudanças significativas em relação aos agentes decisórios da política territorial no Brasil. O Estado, com base na nova Constituição de 1988, repassa uma série de atribuições a outros agentes e instâncias decisórias, tentando torná-los parceiros efetivos e, ao mesmo tempo, agir como "mediador" de processos antes centralizados no governo federal. Foram criados mecanismos constitucionais para a

13 Há uma grande recorrência à importância do espaço físico, enquanto elemento basilar do poder em várias publicações de cunho geopolítico, sobretudo no âmbito das Forças Armadas. O apelo ao território e seus recursos mantém uma série de prerrogativas defendidas pela "Escola Alemã de Geopolítica. Comentários críticos a respeito destas teorias encontram-se, sobretudo, em: KOST, K. (1988); RÖSSLER, M. (1990), SCHÖLLER, P. (1982), e SCHULTZ, H.D. (1989). 
descentralização do poder, ao tempo em que mantém as novas unidades descentralizadas - extremamente frágeis do ponto de vista de suas finanças e de sua infra-estrutura - reféns de um complexo processo que se manifesta, sobretudo, através de restrições de uso em espaços delimitados.

Por outro lado, setores estratégicos clássicos, como o zoneamento, a educação, a saúde, o meio ambiente, dentre outros, estão sendo geridos por diferentes atores, como ONGs, organismos internacionais, sindicatos, associações, cooperativas, empresas, igrejas, com poderes e responsabilidades compartilhadas com o Estado.

Uma obra que retrata esse momento e pode ser considerada uma "obra geopolítica" e de planejamento estratégico foi publicada em 1995 por COSTA, BECKER, MORAES, EGLER, DAVIDOVICH e outros. Trata-se de um atlas geográfico-ambiental, o qual define os novos "macrovetores", através de um conjunto de programas e projetos prioritários do governo, conhecido como "Brasil em Ação".

Os autores desta obra destacam as mudanças que se fazem sentir na postura que o País adota com relação à sua política externa, agora mais flexível, aberta a negociações e parcerias em muitos campos, que anteriormente eram exclusividade do Estado Nacional, e a nova territorialização em forma de "eixos", que se processa a partir dos anos 90 na Amazônia brasileira. O capítulo três mostra alguns desdobramentos dessa proposta, consubstanciada através de "macrovetores" propostos nos Planos de Desenvolvimento Locais e Integrados/PDLIS. Nesse passo é apresentada a tentativa de implantação em municípios roraimenses, nos anos de 2001/2002.

Os "macrovetores" foram concebidos como um novo formato para as políticas públicas brasileiras. A gestão é baseada no uso de alta tecnologia, considerada a base para o "desenvolvimento sustentável", e no compartilhamento de decisões e responsabilidades com toda a sociedade. Parte também do pressuposto de que as ações propostas para o norte do Brasil poderiam impulsionar novas articulações na escala sulamericana.

Sendo impulsionadas por acordos regionais na América do Sul, essas articulações se dão a partir de quatro arranjos territoriais principais: i) Articulações Meridionais com base principal no Mercosul, envolvendo a economia e a infra-estrutura dos países participantes; ii) Articulações Orientais: também vinculadas ao Mercosul priorizando os eixos de circulação das grandes metrópoles do sub-continente: RJ, SP, Curitiba, Porto Alegre, Motevideu, Buenos Aires; iii) Articulações Ocidentais, localizadas na região de 
ocupação e adensamento recentes, do Centro-Oeste brasileiro, e leste da Bolívia, esta sendo uma região com poucos fluxos e potencialmente interessante para os fluxos com países do Pacto Amazônico e, por fim, Articulações Setentrionais. Essas últimas nos interessam mais de perto

As Articulações Setentrionais foram consideradas as de maior potencialidade por possibilitar a abertura de novos fluxos, que vão deste a hidrovia do rio Madeira, entre Manaus e Porto Velho, com conexão com o porto Graneleiro, de Itacoatiara, à exploração de gás e petróleo da província mineral de Urucu; passando pela conexão com o porto peruano de Ilo através do Acre; e pela rede de circulação do "Arco Norte".Esse Arco possibilita novos fluxos na região que vai de Boa Vista, passando por Georgetown e Caiena, e atinge Macapá, do outro lado do Atlântico.

No rol de fluxos que poderão advir dessas articulações, dentre as quais muitas já em curso, têm-se buscado a operacionalização de projetos em várias escalas: a da Amazônia Setentrional; a regional amazônica e aquelas de natureza local. Em todos os projetos desponta como fator de peso a capacidade dos governos de incorporar o componente ambiental como elemento balizador das políticas que estão sendo implementadas.

Isto significa que o debate em torno de impactos ambientais e a efetiva consideração desses aspectos em vários níveis de repercussão no cotidiano das populações afetadas tem levado a uma dura e cara rodada de negociações, cuja solução não se alcança em curto prazo, pois envolve uma série de conceitos e posicionamentos diferenciados e, principalmente, antagônicos. Um dos conceitos caros a essa nova geografia do poder na Amazônia é o de "desenvolvimento sustentável".

BECKER e EGLER (1997:23) interpretam o desenvolvimento sustentável como "um modelo que visa conciliar os conflitos que marcam a transição do final do milênio e implementar uma nova relação sociedade-natureza condizente com o novo modo de produzir. Assim, propõem uma regulação do território de acordo com três princípios básicos: 1) a eficácia de uso dos recursos financeiros e tecnológicos; 2) a potencialidade de cada território; 3) a gestão do território, baseada na parceria público-privado.

A ampla literatura ${ }^{14}$ a respeito do tema mostra, porém, que há várias acepções do conceito de desenvolvimento sustentável, o que dá margem a usos mais ou menos restritivos da natureza. Quase todos, porém, não fogem ao nosso ângulo de abordagem,

14 Vide, p.ex. RATTNER, H. Meio Ambiente e Desenvolvimento Sustentável (2002); SACHS, Ignacy (1986); Relatório Brundtland (1988), dentre outros. Nota-se, porém, que o conceito é multidisciplinar. 
que é justamente a conciliação do discurso ambiental com as recentes políticas de rebatimento territorial na Amazônia, notadamente as de caráter militar.

É importante, ainda, destacar que a base metodológica da Geografia Política, permitirá também uma análise de projetos estratégicos que envolvem a atuação das Forças Armadas no estado de Roraima. Área prioritária do ponto de vista estratégico e militar e um dos pontos centrais na faixa de fronteira do extremo norte do país, Roraima está no centro de projetos estratégicos desde o Calha Norte, criado em 1985.

Sua importância para alavancar o desenvolvimento sustentável, a partir de uma nova estratégia de incorporação das várias etnias presentes neste território, com projetos inovadores, cunhados a partir da utilização sustentável dos recursos aí existentes, pari passo a iniciativas geridas por atores institucionais, a exemplo do SIVAM/SIPAM, constitui um campo de análise bastante promissor também para a Geografia Política.

Considerando a miríade de temas presentes na interpretação dessa realidade e a recorrência conceitual e epistemológica em outros ramos da ciência, procuraremos, a seguir, esclarecer também a recorrência de nossa investigação ao campo da Geografia e das Ciências Sociais. 


\section{I.3 Dialogando com as Ciências Sociais}

As questões de "segurança e defesa" têm sido tratadas em vários âmbitos. Políticos, embaixadores, diplomatas, militares, parlamentares, jornalistas, além dos pesquisadores das Ciências Humanas, de modo geral, têm contribuído para este debate, que se apresenta regido por novos signos e por uma nova lógica, ainda pouco teorizada pela Geografia.

Nos últimos anos, trabalhos importantes, relativos a este tema, têm sido realizados em vários campos da ciência, revelando um novo cenário estratégico na América do Sul e em outras escalas. Algumas dessas obras recentes são centrais na análise que ora se processa.

A primeira delas é a tese de doutorado em Ciência Política de RUDZIT, G. (2003). A segunda é uma dissertação de mestrado em Geografia de MEDEIROS, O. (2004); e a terceira foi escrita pelo professor de Ciências Políticas da Unicamp, OLIVEIRA, Eliézer Rizzo, em 2005. E, por fim, damos destaque às obras do antropólogo Celso CASTRO (2006), do Centro de Pesquisa e Documentação de História Contemporânea do Brasil (CPDOC), vinculada à Fundação Getúlio Vargas, uma das principais recorrências teóricas na nossa análise.

O trabalho de MEDEIROS traz questões paradigmáticas para os "novos tempos" no painel que se esboça no continente americano, com destaque para os acordos de cooperação bi e multilaterais; para a integração e para a atuação conjunta de militares na área da defesa - tradicionalmente peculiar a cada nação. Analisa ainda a importância que passa a assumir a preocupação relativa às novas ameaças no continente americano.

O autor mostra que, a partir da Conferência Especial sobre Segurança, promovida pela Organização dos Estados Americanos (OEA), realizada na Cidade do México, em outubro/2003, o conceito de segurança foi ampliado e passou a conciliar a antiga visão de ameaça militar e de guerras entre estados com as novas preocupações e desafios do continente. Dela resultou a Declaração sobre Segurança das Américas. Conforme Medeiros, Neste documento, problemas como a pobreza, Aids, desastres naturais, meio ambiente, e tráfico de armas e drogas são considerados como as novas ameaças da região das Américas." (MEDEIROS, 2004:112)

Embora não haja uma noção muito clara sobre o significado e mesmo sobre a importância da "segurança" e "defesa", existe um relativo consenso de que, no momento, 
- País precisa concentrar suas bases militares em áreas consideradas frágeis do ponto de vista da segurança e da defesa, tais que as fronteiras do norte, inclusive, pela dificuldade de adequação de outra instituição pública às condições locais. Este pensamento é um consenso entre militares, parlamentares, civis e entre os demais profissionais e especialistas envolvidos no debate.

Após um longo e traumático percurso de vinte anos de regime ditatorial, no qual estas forças obtiveram amplo e irrestrito domínio na vida civil e militar do Brasil, foi proposta, em 1996, uma estrutura de comando integrado das "Armas", similar à existente nos países do centro do sistema capitalista. Após quatro anos de debates, maturação e arranjos institucionais envolvendo essas forças, foi criado, em abril de 1999, o Ministério da Defesa, em substituição aos ministérios singulares: Exército, Marinha e Aeronáutica.

Essa mudança está bem retratada na obra "Democracia e Defesa Nacional", escrita pelo professor Eliézer Rizzo de OLIVEIRA (2005). Trata-se de uma obra fundamental para entender o novo formato que os temas "segurança" e "defesa" vêm assumindo, bem como para entender qual a importância que lhes é atribuída e, ainda, a própria percepção do que seja de fato uma ameaça na atual conjuntura.

Para OLIVEIRA (2005: xxii) a Defesa Nacional é hoje relevante não mais para sustentar os governos, como ocorria na ditadura e no início da redemocratização, mas para assegurar ao Estado brasileiro uma das variáveis da preservação de seus interesses, de apoio ao labor diplomático e, no limite, de sua própria sobrevivência.

Quanto ao distanciamento do tema por parte da academia, a interpretação de OLIVEIRA se baseia na recente história dos países latino-americanos, ou seja, no período que segue após as seqüelas deixadas pelos regimes ditatoriais no continente. No entanto, para o mesmo autor, os partidos políticos, as ONGs e a sociedade civil não avançaram o bastante na direção de uma responsabilidade efetiva pela Defesa Nacional. (2005:54)

Em função dessa situação, a Ciência tem deixado de dar uma contribuição mais efetiva a um tema de suma importância no contexto nacional e internacional. Em razão disso, muitos conceitos e terminologias que envolvem o setor militar têm sido empregados erroneamente, qual seja o caso dos termos "segurança" e "defesa". Para RUDZIT (2003), na academia, a diferença entre os termos poderia passar despercebida, até porque, no Brasil, como diz o autor o termo "segurança" é utilizado para definição de segurança pública, e não externa do país, quando normalmente é usado o termo defesa. (RUDZIT, 2003:7). 
O autor afirma que "a preponderância da correlação entre o conceito e a segurança nacional deu um tom militarizado à interpretação do que vem a ser segurança". Na conclusão de sua análise, RUDZIT sugere que o conceito de segurança, esteja vinculado às novas estratégias de cooperação e integração entre os países, conforme se depreende do trecho abaixo transcrito:

Defesa pressupõe um conjunto de ações relacionadas a conflitos territoriais clássicos. Tais ações são realizadas à sombra da guerra, em um sistema internacional anárquico. As ações de Defesa, majoritariamente, estão relacionadas a um conjunto de ameaças provenientes do exterior. Em outras palavras, as ameaças à Defesa quase sempre possuem origem no "estrangeiro". Tradicionalmente, Defesa tem sido entendido - em última instância - como o direito do uso legítimo da Força por Estados independentes, para defender a integridade de seu povo e de seu território. (Ibidem, P.11)

MEDEIROS reforça esta análise afirmando que

entendemos que, enquanto Defesa pressupõe unidades políticas em disputa no sistema internacional, segurança pressupõe unidades submetidas a regras comuns. Enquanto a primeira sugere competição, a segunda sugere cooperação entre unidades que compõem determinada comunidade de interesses". (MEDEIROS, 2004:63)

$\mathrm{Na}$ visão de muitos autores, para o momento atual, onde muitas decisões são tomadas em conjunto, o conceito mais adequado seria o de "segurança", pois dá a dimensão da integração, do intercâmbio, da cooperação entre países.

$\mathrm{Na}$ atual geopolítica temos a supremacia das questões de Segurança em detrimento das questões de Defesa. Pode-se afirmar que saímos "da contenção para cooperação" - a geopolítica de cooperação e integração, altera a missão tradicional das Forças Armadas. Essa análise tem outras implicações com relação ao papel das Forças Armadas no mundo atual, já que envolve a mudança do seu "ethos" e a procura de uma nova justificação para sua existência, durante anos, apoiada num confronto ideológico da Guerra Fria, não mais existente.

A mudança de foco no setor das Forças Armadas pode ser percebida pelos exercícios em conjunto realizados por militares sul-americanos, as Conferências bilaterais entre Estados-Maiores, as inspeções militares mútuas, as reuniões envolvendo Ministros de Defesa e Estados-Maiores da América do Sul, acordos para a integração setorial de indústrias de Defesa, acordos na área de Inteligência, envio de militares para as missões de assistência humanitária e remoção de campos minados (Peru e Equador). (MEDEIROS, 2004:67) 
Neste sentido, também o conceito de fronteira ${ }^{15}$ adquire nova conotação e permite que novas regras mais flexíveis de intercâmbio sejam implantadas nesses espaços. Abrem-se, ao mesmo tempo possibilidades de respostas conjuntas a grupos de países que se apresentam em desvantagem, quando atuam individualmente no cenário global.

Temos, portanto, um enorme desafio pela frente envolvendo a Geopolítica na Amazônia, pois neste espaço, combinam-se muitas das ameaças temidas por atores hegemônicos no cenário internacional. Os pontos cruciais na Amazônia referem-se à criminalidade transnacional: tráfico, contrabando, garimpo ilegal; depredação ambiental; fogo; desmatamento; invasão de terras indígenas; assassinatos na área rural, para citar os mais expressivos. Também fatores, iminentemente, externos ligados à biopirataria e à gestão da biodiversidade, em vista da fragilidade do Estado frente a poderosos interesses, nem sempre condizentes com um projeto de País, pensado a partir de seus condicionantes internos.

No documento "A National Security Strategy for a New Century", de janeiro de 2000, foi estabelecido como segunda categoria de interesse nacional, "mesmo que não coloque em questão a sobrevivência dos EUA, a proteção do ambiente global contra a destruição da natureza"' (OLIVEIRA, E. R. 2005: 392-393).

Uma vez que em Roraima a "proteção à natureza" e a preservação da etnicidade e da cultura indígenas são faces da mesma moeda, o conceito de "segurança global da natureza", já sentido em várias esferas, parece estar sendo estendido à questão indígena.

Tema de grande interesse, sobretudo por parte de grupos de pressão, que atuam em nível global, a questão indígena esconde, hoje, sob o signo da etnicidade e da sustentabilidade, uma "face primitiva" do debate geopolítico ligado aos recursos naturais, travado desde o final do século XIX até início do século XX. ${ }^{16}$

Parece-nos que a grande nó da questão relaciona-se, por um lado, ao fato de muitos estrategistas, sobretudo militares; recorrerem a velhas teses geopolíticas em

15 Para análise do conceito de fronteira na Geografia, vide MARTIN, A. (1998), e MAGNOLI, D. (1997); SHÄFFER, N.(1995). Podendo ser cotejado ainda com as idéias de COSTA, W. (2002) no que diz respeito à integração sul-americana.

${ }_{16}$ As referências ao tema são amplas, e nós não podemos fugir de uma análise, mais concreta possível, do quadro sócio-econômico, cultural e étnico da Amazônia, nos seus elos com as políticas regionais implantadas, desde as primeiras fases de planejamento estatal para a região. Nesse sentido, refizemos (adiante) o percurso histórico de Roraima, tentando entender o que representa esta sociedade "nos confins do Brasil", quais os agentes hegemônicos, quais os conflitos existentes etc. Devemos reconhecer, que ao final a análise, mesmo se baseando em diferentes fontes - e iremos utilizar, inclusive, muito do que produz a mídia revela apenas "um ponto de vista", de quem viveu, entrevistou, pesquisou um momento desta realidade. 
desuso; por outro, isso se deve a uma ausência de discussão mais ampla na sociedade e entre especialistas de várias áreas.

Os antropólogos são os especialistas que mais têm dado contribuições a esse debate. Sendo o assunto muito amplo e complexo, enfatizamos a ausência generalizada de estudos aprofundados sobre os povos indígenas por parte de outros especialistas. Informações preciosas a respeito do assunto, bem como o acesso às populações indígenas, acabam sendo "domínios exclusivos do saber" (e do poder).

Partimos do pressuposto de que a geopolítica contemporânea nos fornece um bom caminho para refletir sobre estas questões e que as Forças Armadas vêm, paulatinamente, incorporando os seus princípios e concepções em sua agenda a partir do viés sócio-ambiental. Isso se dá na medida em que sociedade, ambiente, etnicidade, segurança e defesa revelaram-se faces da mesma moeda.

Durante o curso Geografia Política e Meio Ambiente ${ }^{17}$, foram feitas algumas reflexões sobre o vínculo entre as questões ambientais e os assuntos militares. Discutimos alguns autores como DABELKO, (1995); ALBAGLI, S. (2001); (CANO, J. S. (1998), que nos apresentam importantes subsídios para pensar este tema. DABELKO (1995) afirma serem várias as concepções propostas quando se discute o emprego militar em questões ambientais, "desde as que consideram que a pressão ambiental é uma ameaça adicional para o modelo clássico de conflito, até as que situam a ameaça ambiental como elemento chave na elaboração de modelos cooperativos de segurança global".

Entende-se que a participação das Forças Armadas nas chamadas "missões verdes" tende a aumentar como conseqüência da própria valorização social crescente dos aspectos ambientais. Neste caso, as possibilidades de emprego do militar nas questões ambientais variam desde a função de "Guardas Florestais" (protetores do meio ambiente), até a de "Guerreiros de Selva" (defensores dos recursos naturais e da integridade territorial)." (MEDEIROS, 2004:39).

A recorrência a esta temática no meio militar tem sido ampliada nos últimos anos. Especificamente, em Roraima, tivemos a oportunidade de entrevistar uma oficial do

17 Curso de Pos-Graduação Oferecido pelo prof. Dr. Wagner Ribeiro, no Departamento de Geografia/USP. 
Exército ${ }^{18}$ que acumula funções na Seção de Saúde e na Seção de Meio Ambiente desta instituição - esta última, recém criada em Roraima.

A oficial atua também diretamente junto aos pelotões de fronteira, na implementação de pequenos projetos voltados à psicultura, à agricultura orgânica, à orientação quanto à manutenção da biodiversidade das áreas do $\mathrm{PEFs}{ }^{19}$. Sua atuação, ainda que incipiente na área de controle e manejo dos recursos naturais, é um exemplo do interesse que o tema desperta e revela a preocupação do setor com uma atuação mais efetiva na área ambiental.

Há também uma grande quantidade de artigos e matérias divulgadas sobre a participação dos militares nas "missões verdes". Embora não tenhamos tido a oportunidade de fazer uma análise mais ampla desse material que foi selecionado durante a pesquisa, os mesmos agregam-se à nossa percepção sobre o assunto.

O que vem ocorrendo neste campo conduz o estabelecimento de políticas de Segurança e Defesa a um novo patamar, que vem se delineando, sobretudo na Amazônia. Nesse sentido, afirma MEDEIROS (2004:42) que "pensar em Segurança vai além das questões de Defesa Interna, e pensar em Defesa não pode mais se resumir a simples percepção egoísta de que o vizinho é sempre uma ameaça e um inimigo em potencial."

Diante desta realidade, temos claro que vivenciamos o surgimento de novos paradigmas nos assuntos de Defesa e Segurança. Nesse cenário, o papel das Forças Armadas é fundamental, sobretudo por sua atuação privilegiada em espaços amazônicos, onde elas são, senão as únicas, pelo menos as mais equipadas para atuar nessas áreas.

Acrescente-se também o evento da criação do Ministério da Defesa, em 1999, que transformou a estrutura institucional de setores militares e abriu espaço para o estabelecimento de parcerias com a esfera civil em projetos e programas antes conduzidos unicamente por atores desta esfera. Este acontecimento é um marco nas transformações operadas no meio militar e reflete em todos os âmbitos do chamado "ethos militar", como veremos no capítulo IV.

Para compreendermos esta questão, focalizamos o processo histórico da instituição militar no Brasil, desde suas origens, em Portugal, com seus desdobramentos

18 Carla A. S. de Aquino, médica veterinária, entrevistada em abril/2005.

19 A FIGURA 7 mostra os Pelotões Especiais de Fronteira/PEFs da Amazônia. Este tema que será tratado no cap. IV. 
na colônia brasileira, sob várias formas. Recorremos, portanto, à História e a trabalhos sociológicos como os de FAORO $(1975,1979)$, além dos trabalhos do antropólogo CASTRO (2006), dentre outros autores citados no capítulo III.

Com esta recorrência histórica, tivemos a preocupação de esclarecer alguns equívocos encontrados em várias obras que consideram que a ocupação da Amazônia, e, consequentemente, do vale do rio Branco, foi eminentemente militar e que centram o foco nos vínculos que existiam entre os grupos armados e o militar, propriamente dito.

Por outro lado, interessou-nos também compreender melhor o universo militar, por ser tão presente em Roraima, embora análises sociológicas desta questão ainda sejam muito incipientes, tendo o nosso trabalho apenas apontado algumas questões que mereceriam tratamento mais minucioso.

Diante de uma realidade extremamente multifacetada como a que nos propomos abordar, têm as ciências humanas um grande desafio para compreender tão grandes transformações sócio-espaciais, que além disto, operam numa velocidade cada vez mais acentuada. 


\section{CAPÍTULO II - Espaço e poder na Amazônia}

\section{II.1. Caracterização de um espaço de singularidades}

O Estado de Roraima destaca-se por sua posição estratégica no norte do Brasil. Localizado a $850 \mathrm{~km}$ de Manaus, pode-se configurar como um mercado potencialmente capaz de abastecer três milhões de habitantes do estado do Amazonas, a partir de seus pólos hortigranjeiros e leiteiros, dentre outras conexões importantes como a saída pelo Porto de Itacoatiara - a 800 km da capital Boa Vista - através do Porto de Caracaraí/RR. Destaca-se, também, a saída pelo Porto de Georgetown, distante 550 km de Boa Vista.

O Porto de Itacoatiara faz parte de um corredor fluvial que liga os rios Amazonas e Madeira ao Oceano Atlântico permitindo o transporte de grãos da região norte para Roterdã na Holanda. Através deste Porto Roraima poderá exportar soja para Europa. ${ }^{20}$ (GOVERNO DO ESTADO DE RORAIMA, 2003:69)

\section{FIGURA 1}

\section{EIXOS DE INTEGRAÇÃO AMÉRICA DO SUL SETENTRIONAL}

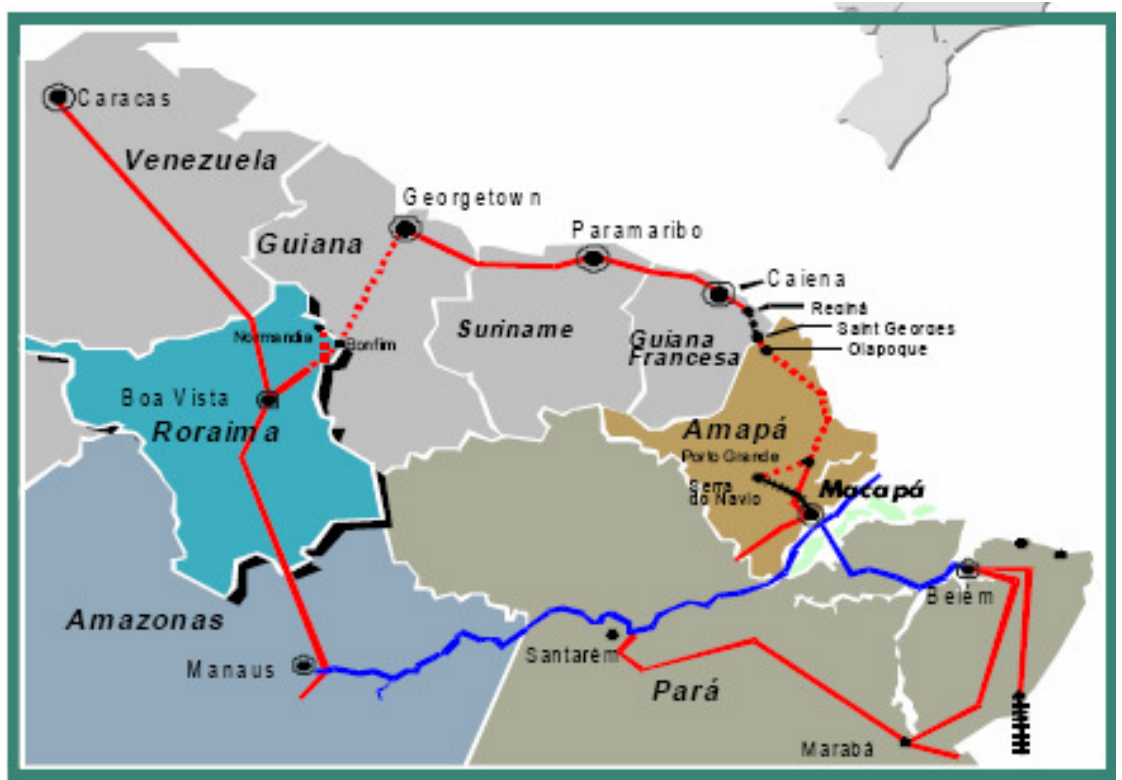

Fonte: MINISTÉRIO DA DEFESA, FGV/ISAE, 2000:22 
Outro eixo com grande potencialidade de alavancar a economia local deste Estado está situado a $541 \mathrm{~km}$ de Boa Vista e a $88 \mathrm{~km}$ de Georgetown e se dá através do Porto de Berbice, localizado na República Cooperativista da Guiana. Através deste porto, o Estado de Roraima poderá estabelecer relações comerciais com grandes mercados mundiais como Caribe, Estados Unidos e Europa. Isso permite superar um dos principais entraves na área de importação e exportações de produtos, representado pelo alto custo do transporte, como fica claro no trecho a seguir transcrito:

O Porto de Berbice propiciará, através de integração de sistemas multimodais a interligação do Brasil (estados de Roraima e Amazonas), com a Guiana, Suriname, Leste do Peru, Sul da Colômbia, Sul da Venezuela, bem com a Guiana Francesa, e estado do Amapá, através de rodovia já implantada. Facilitara, ainda a implementação de Áreas de Livre Comércio em diversos países e Estados. ${ }^{21}$

FIGURA 2

\section{POSIÇÃO ESTRATÉGICA DE RORAIMA}

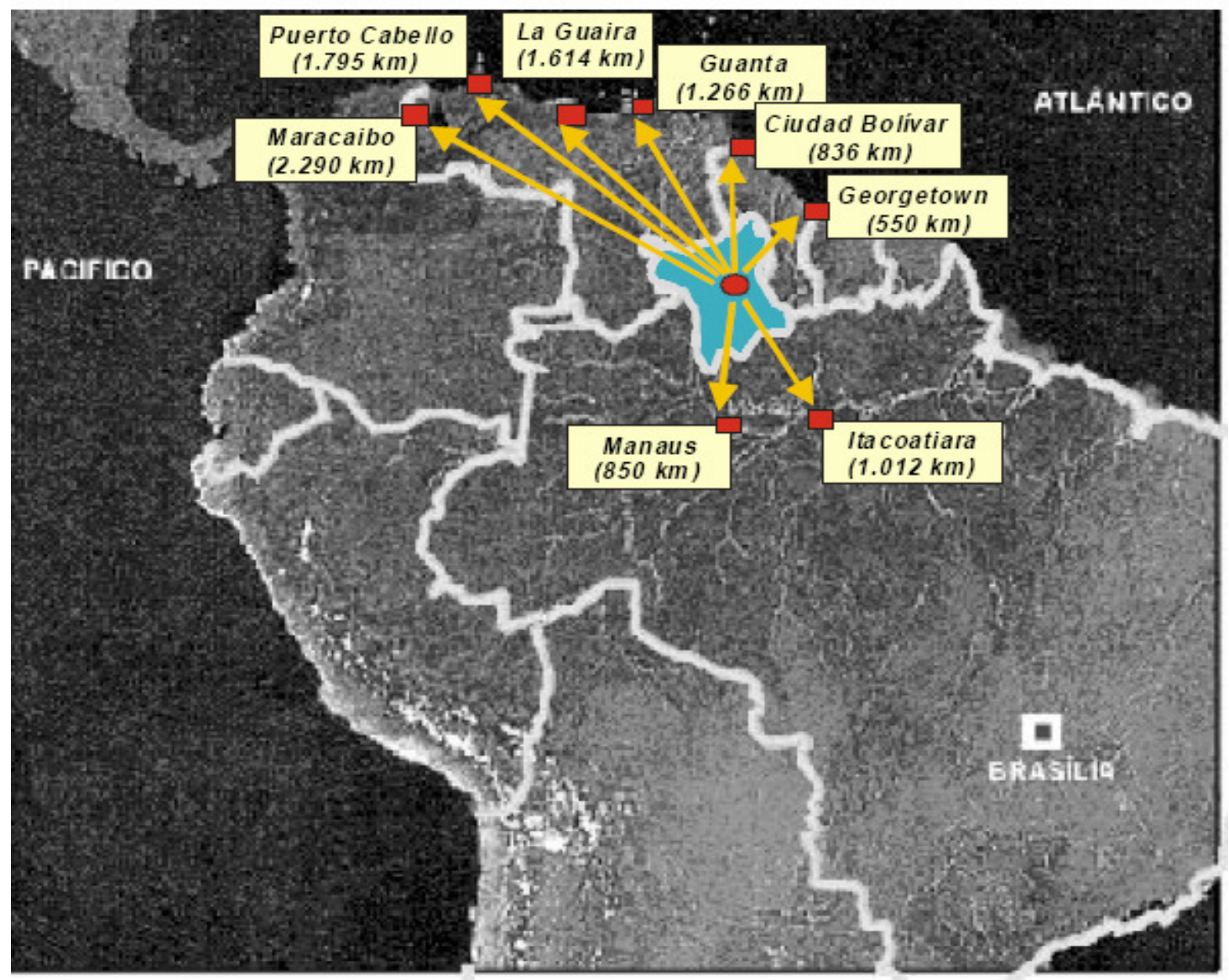

Fonte: MINISTÉRIO DA DEFESA, FGV/ISAE, 2000:22

21

Ibidem 
Para Estabelecer a comunicação com as vias de acesso apontadas nas figuras anteriores três importantes rodovias federais cortam o território roraimense: a BR-174, que liga o Estado à Venezuela, ao Norte, e ao Estado do Amazonas, ao Sul; a BR-210 (Perimetral Norte); e a BR-401, que liga Boa Vista à Lethem, na fronteira com a Guiana, ao Leste. Acrescenta-se ainda cerca de 1.380 quilômetros de estradas federais, além das dezenas de estradas estaduais e vicinais resultante dos projetos de assentamento agrícola.

Na concepção de SANTOS (2004:185):

O valor da colonização de Roraima pode ser dado não só porque oito de seus quinze municípios tiveram origem em colônias oficiais, mas pelo fato de que foi a partir desses pontos de fixação, junto a estradas denominadas de integração, que a maior parte de seu território foi efetivamente ocupado e paulatinamente explorado.

Estas vias foram construídas segundo a lógica de ocupação do território dominante na década de 1970 e possibilitaram a vinda de migrantes de várias partes do país. Ainda que no início desta década os núcleos agrícolas não fossem considerados programas do governo de Roraima, nos anos posteriores, sob impulso do governador Ottomar de Souza Pinto, a política de assentamentos rurais foi efetivamente incorporada à vida do então território federal.

O mapa a seguir ilustra a proximidade das sedes de municípios às vias de acesso existentes atualmente em Roraima. 
MAPA 1

Rodovias Federais em Roraima e a localização das sedes de municípios

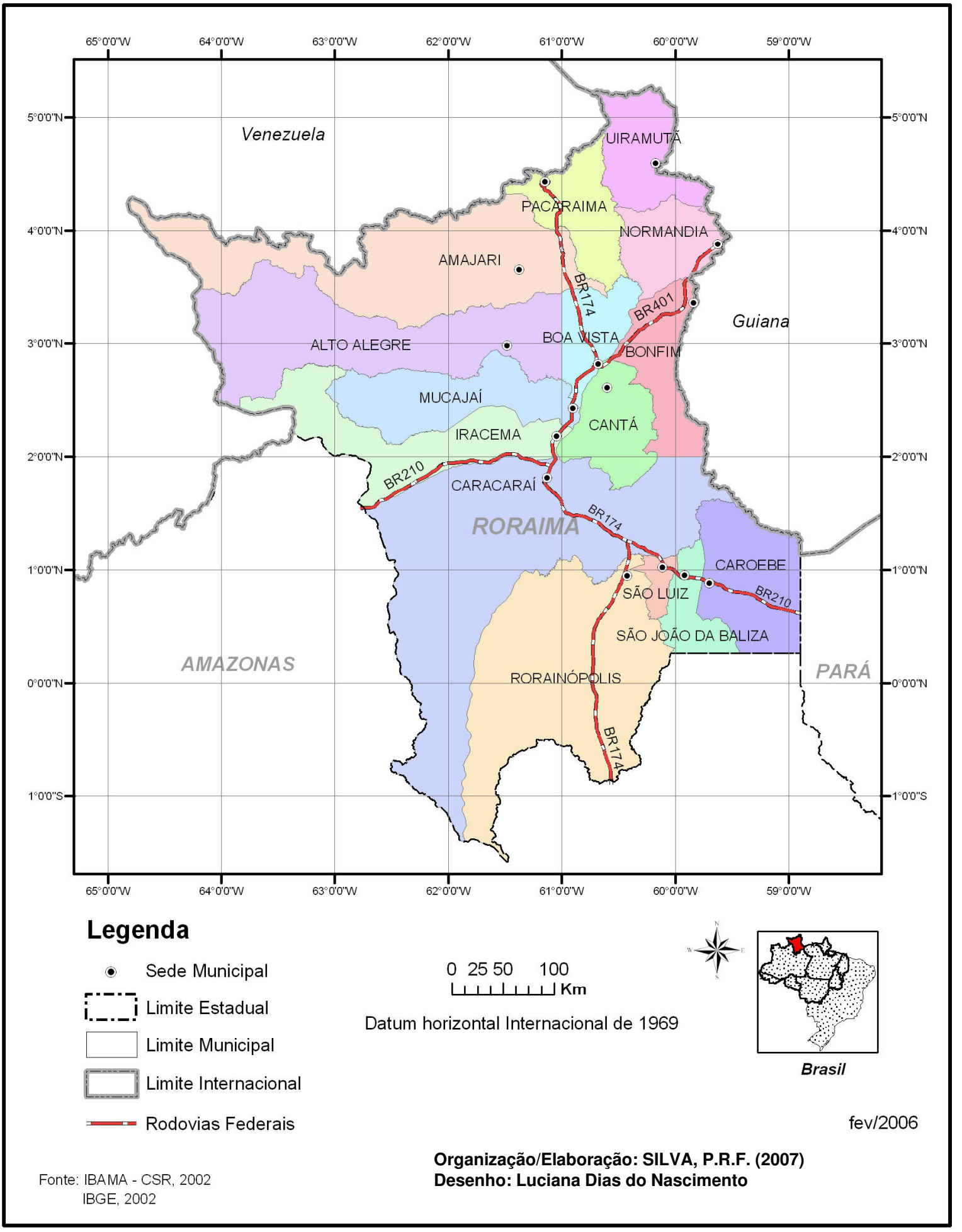


Com mais de 225 mil quilômetros quadrados de área e uma população estimada em 2007 em 403.344 habitantes $^{22}$, Roraima apresenta, em sua composição, a maior percentagem de indígenas em relação a outras áreas do País. As etnias predominantes são Macuxi, Wapixana, Ingaricó, Patamona, Wai Wai e Taurepang. O Censo promovido pelo Distrito Sanitário Leste de Roraima, em 2005, apresenta um total de 33.169 indivíduos. Deste total, aproximadamente 28.000 indígenas são classificados como Macuxi, os quais vivem espalhados por 250 comunidades em toda parte leste do Estado. $^{23}$

Somam-se ainda, os grupos Yanomami e Yekuana, contabilizados pelo Distrito Sanitário Yanomami/Dsei em 15.896 indígenas, espalhados, em aproximadamente 200 aldeias $^{24}$, numa área que abrange uma grande extensão da fronteira do Brasil com a Venezuela. A maioria desta população em território brasileiro. (FIGURA 3)

22 Estimativa fornecida pelo IBGE-RR em maio/2007.

23 Distrito Sanitário Indígena do Leste de Roraima-DSL. Censos 2005 e 2006.

$24 \quad$ Fonte: Dsei Yanomami/Funasa/CR/RR. Censo populacional atualizado em julho de 2006. 
FIGURA 3

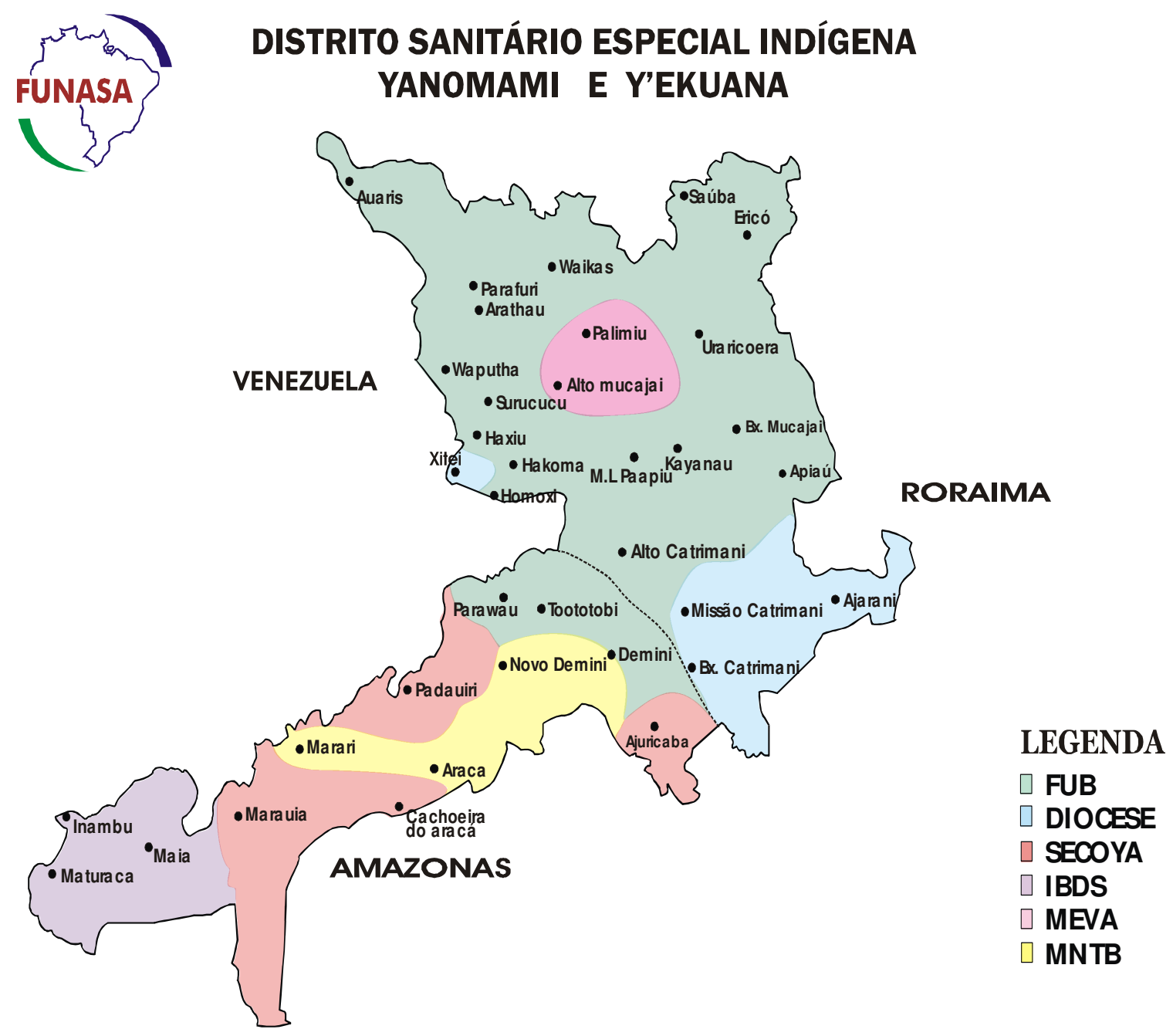

As diferenças existentes no Estado de Roraima em relação ao resto do país também são visíveis tanto na estrutura de sua economia, totalmente dependente da União, como ainda no que diz respeito aos aspectos sociais de suas populações ${ }^{25}$, formadas em sua maioria por migrantes de outros Estados brasileiros. Parte destes migrantes é composta de funcionários públicos que mantém fracos elos de integração local e é transferida após poucos anos de permanência no Estado.

$25 \quad$ Além do "ethos militar", já mencionado anteriormente, é evidente na paisagem roraimense uma forte "cultura do garimpo", que se expressa de diferentes maneiras no comportamento da população, no relacionamento com o trabalho, na dificuldade em estabelecer raízes mais sólidas com o local, dentre outros aspectos, muito pouco estudados. Alguns trabalhos apontam certas características sem, no entanto, aprofundalas. Vide: RODRIGUES, 1996. 
Dos seus quinze municípios, somente Boa Vista tem mais de 30.000 habitantes e concentra praticamente toda a infra-estrutura disponível no Estado. A cidade de Boa Vista, com 242.179 habitantes, segundo estimativa do IBGE de 2005, abriga mais de $60 \%$ de sua população. (Conforme TABELAS 1 e 2 abaixo). Alavancar a economia desses municípios, criados numa conjuntura de forte pressão do setor ambiental, concomitante a políticas de inserção à economia global, tem sido um verdadeiro desafio para o Estado.

Atuando em resposta a demandas provenientes, no início, basicamente, do exterior, a favor da preservação das florestas tropicais e de seus povos indígenas, a consolidação da legislação e da burocracia estatal no Brasil em torno do meio ambiente ocorreu, assim, não por via de forças autárquicas interessadas na ampliação do aparato de coerção pública em defesa da soberania nacional nesse setor, mas, antes, reagindo, ou melhor, interagindo com uma das frentes mais expressivas de enfraquecimento das fronteiras nacionais no mundo contemporâneo, constituída em torno das questões ambientais. ${ }^{26}$

TABELA 1

\begin{tabular}{|l|c|c|c|}
\hline \multicolumn{3}{|c|}{ População de Roraima, por município, entre 2005 e 2000 } \\
\hline \multicolumn{1}{|c|}{ Município } & $\begin{array}{c}\text { População em 2005 } \\
\text { (estimativa) }\end{array}$ & População em 2000 & Crescimento absoluto \\
Boa Vista & 242.179 & 200.568 & 41.611 \\
Rorainópolis & 24.615 & 17.393 & 7.222 \\
Alto Alegre & 22.102 & 17.907 & 4.195 \\
Caracaraí & 17.746 & 14.286 & 3.460 \\
Bonfim & 12.626 & 9.326 & 3.300 \\
Mucajaí & 11.649 & 11.247 & 402 \\
Cantá & 10.482 & 8.571 & 1.911 \\
Pacaraima & 8.215 & 6.990 & 1.225 \\
São Luiz do Anauá & 6.490 & 5.311 & 1.179 \\
Uiramutã & 6.430 & 5.802 & 628 \\
Amajari & 6.087 & 5.294 & 793 \\
Iracema & 6.060 & 4.781 & 1.279 \\
Caroebe & 5.869 & 5.692 & 177 \\
São João da Baliza & 5.432 & 5.091 & 341 \\
Normandia & 5.335 & 6.138 & -803 \\
Roraima & 391.317 & 324.397 & 66.920 \\
\hline
\end{tabular}

Fonte: Site: www.ibge.gov.br Cidades@. Acesso em junho/2006 
TABELA 2

\begin{tabular}{|l|c|c|}
\hline \multicolumn{2}{|c|}{ População total e percentual da população de Roraima por municípios - 2000 } \\
\hline Monicípios & $\begin{array}{c}\text { População total } \\
\text { (mil habitantes) }\end{array}$ & $\begin{array}{c}\text { Porcentagem da população } \\
\text { Alto Alegre }\end{array}$ \\
Rorainópolis & 17.907 & $62 \%$ \\
Caracaraí & 17.393 & $6 \%$ \\
Mucajaí & 14.286 & $5 \%$ \\
Bonfim & 11.247 & $4 \%$ \\
Cantá & 9.326 & $3 \%$ \\
Pacaraima & 8.571 & $3 \%$ \\
Normandia & 6.990 & $3 \%$ \\
Uiramutã & 6.138 & $2 \%$ \\
Caroebe & 5.802 & $2 \%$ \\
São Luiz do Anauá & 5.692 & $2 \%$ \\
Amajari & 5.311 & $2 \%$ \\
São João da Baliza & 5.294 & $2 \%$ \\
Iracema & 5.091 & $1 \%$ \\
Roraima & 4.781 & $2 \%$ \\
\hline
\end{tabular}

Fonte: Censo Demográfico do IBGE (2000).

$\mathrm{Na}$ sua maioria, os municípios roraimenses foram impulsionados por projetos de colonização agrícola sem sucesso e sem continuidade no presente. Seis deles foram criados em 1982 e sete entre 1994 e 1995, numa conjuntura de descentralização, instituída pela Constituição de 1988 que não garantiu as mínimas condições para a realização do chamado desenvolvimento sustentável, adotado discursivamente pela maioria dos atores que interferem nas políticas do Estado de Roraima. (TABELA 3) 
TABELA 3

\begin{tabular}{|l|c|}
\hline \multicolumn{2}{|c|}{ A emancipação política dos municípios de Roraima } \\
Boa Vista & Ano da emancipipação política \\
Caracaraí & $1890^{*}$ \\
Alto Alegre & $1955^{\star *}$ \\
Mucajaí & $1982^{* *}$ \\
Bonfim & $1982^{\star *}$ \\
Normandia & $1982^{* *}$ \\
São Luiz do Anauá & $1982^{* *}$ \\
São João da Baliza & $1982^{* *}$ \\
Iracema & $1982^{* *}$ \\
Caroebe & $1994^{* * *}$ \\
Amajari & $1994^{* * *}$ \\
Uiramutã & $1995^{\star * *}$ \\
Pacaraima & $1995^{\star * *}$ \\
Rorainópolis & $1995^{\star * *}$ \\
Cantá & $1995^{* * *}$ \\
\hline
\end{tabular}

OBS.: ${ }^{*}$ Como parte do estado do Amazonas. / ${ }^{* \star}$ Como Território Federal. $/{ }^{* \star *}$ Como Estado Fonte: FREITAS (1996). Elaboração: SILVA, P.R.F (2007)

Do ponto de vista sociológico, chama atenção uma elite local, composta, em sua maioria, por servidores federais vindos de outras áreas do Brasil, muitos dos quais militares, o que certamente contribui para este "ethos militar"27 percebido neste espaço especial do Brasil.

Nilson Crócia de Barros, geógrafo que realizou durante cinco anos extensa pesquisa sobre Roraima e áreas fronteiriças da Guiana e Venezuela, analisa a questão da seguinte maneira:

Com a fundação do forte de São Joaquim e a implantação das fazendas reais, os campos do rio Branco estavam incorporados ao projeto amazônico de Pombal de ocupação e domínio. A cultura do gado e a fortaleza fixaram ali um pequeno grupo de origem européia, que se impôs ao indígena e deu origem a um setor social e político de relevância no futuro. Membros do contingente militar foram se

$27 \quad$ É difícil precisar a participação de militares no Estado de Roraima, pois no geral, o militar que vem transferido, não permanece mais que dois anos no Estado, mas o contato com a população local permite perceber, que alguns militares voltam depois de alguns anos, em especial, quando já estão na reserva. 
casando com índias e formando famílias, o que era facilitado pelas autoridades, enquanto os militares mais graduados, quase sempre oriundos no Nordeste, trouxeram suas famílias. Seus descendentes se tornaram fazendeiros, privatizando as terras das fazendas reais e, incorporando elementos chegados mais recentemente, como na passagem do século XIX para o XX, originaram grupos familiares que ainda têm projeção social em Roraima. (BARROS, 1995, apud SANTOS, 2004:82).

Outra característica destacada por pesquisadores chama a atenção para os traços de uma sociedade patrimonial e assistencialista na cultura roraimense. Políticos locais, até recentemente, ofereciam de empregos públicos - sem concursos - a mantimentos, roupas, mosquiteiros, brinquedos etc. Há relatos de que políticos chegavam a oferecer bronzeador, roupas de banho, dentre outros itens, para que a população local pudesse desfrutar das excelentes áreas de lazer existentes na área central de Boa Vista. Mesmo em relação às comunidades indígenas, que têm atendimento diferenciado no Estado, a rede de clientelismo se mantém, como nos apresenta o antropólogo Maxim Repetto:

"O DAÍ (Departamento de Assuntos Indígenas - órgão vinculado à SETRABES - Secretaria de Trabalho e Bem Estar Social do Estado de Roraima), é a instância que atende os pedidos feitos por comunidades, organizações indígenas ou lideranças indígenas; tem, por isso, um papel fundamental na estrutura clientelística e de poder local nas ações indigenistas do Governo Estadual. Isto permitiu à pessoa que dirigiu o DAÍ até 2.000, eleger-se prefeita do município de Uiramutã, para o período de 2000-2004, com o apoio do grupo de Neudo Campos." (REPETTO, 2002:89)

Roraima como parte de um processo sócio-econômico mais amplo, apresenta as peculiaridades inerentes a um espaço que permaneceu isolado até o século $X X$, no que se refere aos fluxos comerciais existentes em outras áreas do País e até mesmo da Amazônia, em função da inexistência de uma rede de comunicação que conectasse essa área ao resto do País. Mesmo que tenha sido alvo de preocupações geopolíticas, a conexão do vale do Rio Branco com o País só se efetivou a partir da década de 70, com a construção da BR-174. (Vide mapa 1)

As primeiras atenções dedicadas ao vale do Rio Branco deram-se durante o governo do Marquês de Pombal, ministro português (1750-1777) que passou a perceber a Amazônia como área estratégica no sentido político e mercantilista. Pombal promoveu o "fechamento" dos caminhos de entrada para Amazônia - os rios - por meio de construção de fortalezas. As preocupações pombalinas com a Amazônia eram também parte de uma outra mais geral: o contrabando no comércio, praticado nas fronteiras da colônia, fosse na Amazônia ou no sul brasileiro. (SANTOS 2004:84) 
Foi Lobo D'Almada, comandante do Forte que durante os anos de 1779/84 realizou os primeiros intentos de ocupação efetiva do vale do Rio Branco. Ele introduziu o gado bovino com o objetivo de abastecer o povoamento que começava a se estabelecer na região deste Vale, bem como os tropeiros que por ali circundavam, na rota dos principais surtos extrativos da região.

No âmbito deste comércio incipiente, surgiram as fazendas de gado, açúcar, farinha, denominadas Fazendas Reais: São Felipe, Nossa Senhora da Conceição, Santa Bárbara, Santa Isabel e Nossa Senhora do Carmo, atual Boa Vista. Segundo alguns autores, essas fazendas apresentaram-se como importante instrumento estratégico na disputa das fronteiras com a Guiana Inglesa.

A fazenda São Marcos foi fundada pelo comandante do Forte São Joaquim Sá Sarmento, a fazenda São José pelo comerciante José Antonio Évora. Cabe ser ressaltado que estas propriedades eram particulares, não pertencendo ao rei como alguns equivocadamente consideram. (AGOSTINHO, 2000:62)

A questão da propriedade dessas fazendas é um fato bastante recorrente na sociedade roraimense, por envolver a participação de antepassados da elite local, que teriam se apropriado de um patrimônio pertencente, em diferentes momentos, a várias jurisdições. Tendo havido tantas mudanças institucionais, falta de controle cartorial e outros prováveis ilícitos, desde a implantação dessas fazendas tiveram diferentes status: Distrito, Território, Estado. Parte delas, ou segundo alguns autores, todas elas, são denominadas "Fazendas Reais", incorporadas à União, após a independência.

“... Tal é o caso das terras devolutas, que além de constituírem terras indígenas, portanto terras patrimoniais da União, encontravam-se em área de fronteira, cuja transferência aos estados a Constituição de 1891 expressamente vetava."(SANTILLI, 2001).

Aqui temos dois elementos essenciais à compreensão dos conflitos fundiários que se travam ainda hoje: a "imemorialidade das terras indígenas", já consagrada na Constituição Brasileira; e a questão da "faixa de fronteira", também ponto nevrálgico para o setor militar, também garantido pela constituição. Este assunto foi discutido na dissertação de MONTANARI, JR., 2005, que não vê antagonismo entre os dois "tipos de usos", sobretudo no presente, quando a tendência é haver uma maior discussão com a população envolvida.

O fato de Roraima ter entrado tardiamente no rol das unidades federativas que buscam integrar-se ao modelo econômico vigente no País colocou para o Estado o desafio de repensar o relacionamento com os grupos étnicos remanescentes que se 
concentram nesta "última fronteira". Fato que não se deu em outras áreas já conectadas aos circuitos produtivos, cujas populações indígenas foram sumariamente negligenciadas, quando não, exterminadas.

A economia de Roraima permaneceu sem o menor dinamismo até a década de 1940, quando a população de migrantes, que se fixou em sua maior parte em Boa Vista, atraída pela mineração que se expandia naquele momento, mais ao norte, e pelas atividades administrativas, nos diversos órgãos do novo aparato estatal - vai aos poucos superando a mais antiga. ${ }^{28}$ BARROS (1995)

O fato mais marcante nessa década foi a criação dos Territórios Federais em áreas fronteiriças da Amazônia. Em 1943, o Presidente Getúlio Vargas criou cinco Territórios Federais: Rio Branco (posteriormente, Roraima) Guaporé (posteriormente, Rondônia), Amapá, Iguassú e Ponta Porã. Os dois últimos foram extintos em 1946. O principal objetivo alegado para a criação dos Territórios Federais, numa conjuntura de guerra mundial, era o de "ocupar os espaços vazios do território nacional", e em especial na Amazônia, pois, segundo essa visão, um "espaço vazio" não estaria seguro à ocupação exógena.

O primeiro governador, nomeado para Roraima, tomou posse em 1944 capitão Ene Garcez dos Reis - foi duro e ditatorial, apoiado por um contingente de 200 homens armados, houve proibição de reuniões e ajuntamentos, recolhimento das pessoas às $18 \mathrm{~h}$ aos seus lares... numa terra na qual alegava-se estar dominada pelo banditismo e falta de justiça. (SANTOS, 2004:98)

O interesse na colonização neste vale não correspondeu à implantação de núcleos efetivos e permanentes, em vista das condições de isolamento local e de toda sorte de dificuldades advindas deste aspecto. Por mais de um século, registram-se apenas algumas fazendas, com pouco dinamismo econômico, como se verá adiante.

A criação do Território Federal do Rio Branco, em 1943, permitiu que uma polícia de segurança e defesa começasse a ser instituída nessa área, a partir da vinda de governadores indicados pela União. Mas o quadro de estagnação permanece até os anos 80 , quando ocorre uma forte explosão demográfica ocasionada pelo garimpo.

28 O primeiro Território Federal brasileiro foi o do Acre, em 1903, em função de conflitos específicos nessa área. 
Até a década de 80 não houve mudanças na base produtiva local: continuaram as atividades intermitentes ligadas ao garimpo, à extração de madeira e de outros produtos naturais, e a agro-pecuária de pequena expressão regional. Nota-se, no entanto, a instalação de alguns órgãos de governo e o início de uma "casta de políticos e servidores federais". (SANTOS, 2004:230)

Há um dado importante a ser considerado em relação à instabilidade política dos primeiros vinte anos da fase de território. De 1943 a 1964, Roraima teve 15 governadores titulares, a maioria militares. "O senador Vitorino Freire, do Maranhão, indicou direta ou indiretamente, 10 desses governadores, numa prova de sua influência política junto ao governo federal. Cada governador, no entanto ficou pouco tempo (média de 16 meses). Nesse curto espaço de tempo, aliado ao desconhecimento do Território, o governante quase nada podia realizar." (IBIDEM)

A tabela a seguir mostra a dinâmica referida acima. 
TABELA 4

\section{Governadores RORAIMA - RR}

17.04.1944 a 22.02.1946 22.02 .1946 a 28.05 .1947 28.05.1947 a 03.03.1949 03.03.1949 a 23.02.1951 23.02.1951 a 06.10.1951 06.10 .1951 a 16.06 .1952 16.06 .1952 a 15.07 .1953 15.07.1953 a 26.01.1955 26.01.1955 a 13.06.1955 13.06.1955 a 23.11.1955 23.11.1955 a 29.01.1959 29.01.1959 a 02.03.1961 02.03.1961 a 02.09.1961 12.10.1961 a 30.01.1963 30.01 .1963 a 16.06 .1964 16.06.1964 a 10.04.1967 10.04.1967 a 28.03.1969 29.04.1969 a 12.03 .1970 12.03.1970 a 03.04.1974 03.04.1974 a 02.04.1979 02.04.1979 a 07.04.1983 07.04.1983 a 19.12.1983 19.12.1983 a 26.06.1985 26.06.1985 a 14.10.1987 14.10.1987 a 15.09 .1988 15.09.1988 a 01.01.1991 01.01 .1991 e 01.01 .1995 01.01 .1995 a 01.01 .1999 01.01 .1999 a 01.01 .2003 01.01 .2003 a 09.11 .2004

09.11 .2004 (atual)

Fonte: FREITAS, A. (1997)
ENE GARCEZ DOS REIS, Capitão FÉLIX VALOIS DE ARAÚJO, Tenente-Coronel CLÓVIS NOVA DA COSTA, Capitão MIGUEL XIMENES DE MELO GEROCÍLIO QUEIROS BELARMINO NEVES GALVÃO, Tenente-Coronel AQUILINO MOTA DUARTE JOSÉ LUIZ DE ARAÚJO NETO AURIZ COELHO E SILVA, Tenente-Coronel ADEMAR SOARES DA ROCHA, General-de-Brigada JOSÉ MARIA BARBOSA, Capitão HÉLIO MAGALHÃES DE ARAÚJO DJACIR CAVALCÂNTI DE ARRUDA CLÓVIS NOVA DA COSTA, General FRANCISCO DE ASSIS ALBUQUERQUE PEIXOTO DILERMANO DA CUNHA ROCHA, Ten.Cel.Av HÉLIO DA COSTA CAMPOS, Cel. Av WALMOR LEAL DALCIN, Major-Aviador HÉLIO DA COSTA CAMPOS, Coronel-Aviador FERNANDO RAMOS PEREIRA, Coronel-Aviador OTTOMAR DE SOUZA PINTO, Coronel-Aviador VICENTE DE MAGALHÃES MORAES, Maj.Brig. Ar ARÍDIO MARTINS DE MAGALHÃES, General GETULIO ALBERTO DE SOUZA CRUZ ROBERTO PINHEIRO KLEIN, General ROMERO JUCA FILHO OTTOMAR DE SOUZA PINTO NEUDO RIBEIRO CAMPOS NEUDO RIBEIRO CAMPOS, Reeleito FRANCISCO FLAMARION PORTELA OTTOMAR DE SOUZA PINTO 
Segundo Freitas (1996), a partir do terceiro governador (1951-1952) foi implantado um programa de colonização de excelente qualidade, oferecendo-se aos colonos desde passagem e hospedagem, a lotes, a ferramentas agrícolas e assistência técnica. Este programa permitiu a fixação de colonos nos municípios do Mucajaí e Cantá.

As mudanças estruturais em Roraima, a partir do final da década de 1960 e parte da seguinte, devem-se muito à estabilidade dos governantes. Foram oito governadores durante os vinte anos de regime militar, com relativa autonomia de decisão, além de aporte de recursos oficiais.

Dado os critérios de escolha já existentes, por sua condição de território, os governantes tinham boas relações com Brasília, principalmente com os ministros do Interior e Aeronáutica. Algumas fontes afirmam que, durante o Regime Militar, os territórios foram concedidos às Forças Armadas, da seguinte maneira: Roraima foi destinado à Aeronáutica; Amapá foi destinado à Marinha, e Rondônia ao Exército.

Chama atenção, sobretudo para quem vivenciou o Regime Militar no Sudeste, com o forte grau de repressão que existiu nessa área, o fato de Roraima, do ponto de vista de sua economia, ter-se beneficiado do regime, segundo o "consenso local", pois esta área, recebeu a infra-estrutura básica, que até hoje permanece praticamente a mesma.

O Estado, nos anos 70 foi beneficiado com uma infra-estrutura de transporte, habitação e demais instalações públicas, para fins de funcionamento da máquina administrativa aqui instalada. Deve ser considerado também o afastamento dos conflitos ocorridos em função da repressão da ditadura militar, em relação a outras áreas de economia mais dinâmica e com maior grau de mobilização da população civil.

Mais adiante esclareceremos melhor a situação econômica vivenciada pelo Estado de Roraima. Nesta seção, procuramos apenas estabelecer alguns marcos que interferem na compreensão desta geopolítica que vem definindo este espaço desde sua constituição como território federal, na década de 40, qual seja, o momento em que se inicia o fortalecimento do aparato de segurança e defesa nesta área.

Não obstante, é no final da década de 1960 que se passa do discurso de ocupação dos "espaços vazios" amazônicos para sua efetiva incorporação às preocupações geopolíticas existentes, de modo mais amplo, em toda América Latina.

Vivia-se o momento da "Guerra Fria", com desdobramentos no entorno mais próximo de Roraima. Destaca-se nesta área a instável situação política na Guiana, que 
rompeu com a metrópole inglesa em 1966 e em 1968 nacionalizou os principais setores da economia, estreitando suas relações com o bloco socialista. Ademais, na área do Caribe, o Socialismo implantando em Cuba e a situação instável na Venezuela representavam para os militares brasileiros um perigo latente de extravasamento de "conflitos e ideologias" para as fronteiras do Brasil.

Em 1969, tropas foram deslocadas de Manaus e Belém para esta fronteira, correspondendo às preocupações com as questões apontadas acima. Um novo cenário de grandes transformações sócio-espaciais começa a se delinear nessa área. A mais importante delas vai se consolidar com o deslocamento do $6^{\circ}$ Batalhão de Engenharia de Construção/BEC para Boa Vista, em 1972. Trata-se de uma política de infra-estrutura mais ampla, que passaria a marcar a vida do Território.

E, para garantir o controle de suas fronteiras, o governo militar aumentou consideravelmente sua presença nessas áreas, através da criação de Pelotões Especiais de Fronteiras - PEFs, conforme análise presente no Capítulo IV desta tese. 


\section{II.2. Os recentes processos de estruturação do Estado de Roraima}

O estado de Roraima é apontado como uma nova fronteira na Amazônia, não obstante a forte resistência de grupos ${ }^{29}$ que defendem a necessidade de preservação da natureza e do modo de vida das populações indígenas, que estariam em descompasso com a idéia de "fronteira de recursos".

A população indígena do Estado gira em torno de 50.000 pessoas, aproximadamente $12,5 \%$ do total da população do Estado. Este número tem aumentado, significativamente nos últimos anos, devido ao forte movimento de reconhecimento étnico desses grupos. O preconceito e a exclusão vivenciados secularmente por esses povos conduziram ao ocultamento de suas identidades étnica, processo que vem sendo revertido a partir da grande mobilização destes povos, ocorrida nas últimas décadas.

Outros fatores, como a recente homologação da área indígena Raposa/Serra do Sol, ocorrida em abril de 2005, conduzida por atores internos e externos a esses grupos, além da assistência especial que lhes é destinada, são também elementos importantes para se entender a posição que o elemento étnico assume no Estado de Roraima, nos últimos anos.

A homologação de 1,7 milhões de hectares que constitui a área indígena Raposa/Serra do Sol, somada às áreas indígenas já existentes e às áreas destinadas à Unidades de Conservação e a outros usos institucionais (MAPA 2, abaixo), têm levado a um debate muito acirrado em relação ao "engessamento da economia" e à "impossibilidade de desenvolvimento" na área restante, que corresponde a $40 \%$ da área total do Estado. Este número é veementemente contestado pela elite local que alega que, desses $40 \%$ restantes, $10 \%$ representam áreas alagadas e montanhosas e mais de $20 \%$ estariam sujeitos à legislação ambiental restritiva para uso agropecuário.

(...) O que há de interessante neste cenário, é o fato de que o governo ultimamente não tem atacado de forma direta os índios, como acontecia nos anos anteriores. Na atual conjuntura foram os indígenas que se enfrentaram entre si. Estes conflitos se centraram sobre a demarcação da T.I Raposa Serra do Sol e sobre a retirada dos invasores da T.I." São Marcos. (REPETTO, 2002:96)

\footnotetext{
29 Ainda que estes grupos sejam reduzidos em relação a população do Estado - fortemente contrária ao estabelecimento de políticas diferenciadas para os indígenas - a dimensão da importância dos mesmos ultrapassa em muito os contornos geográficos da área. A eficácia desses "grupos de pressão", deve ser compreendida em seus elos globais, e nacionais, e, através das figuras formadoras de opinião pública, da mídia, dentre outros.
} 
MAPA 2
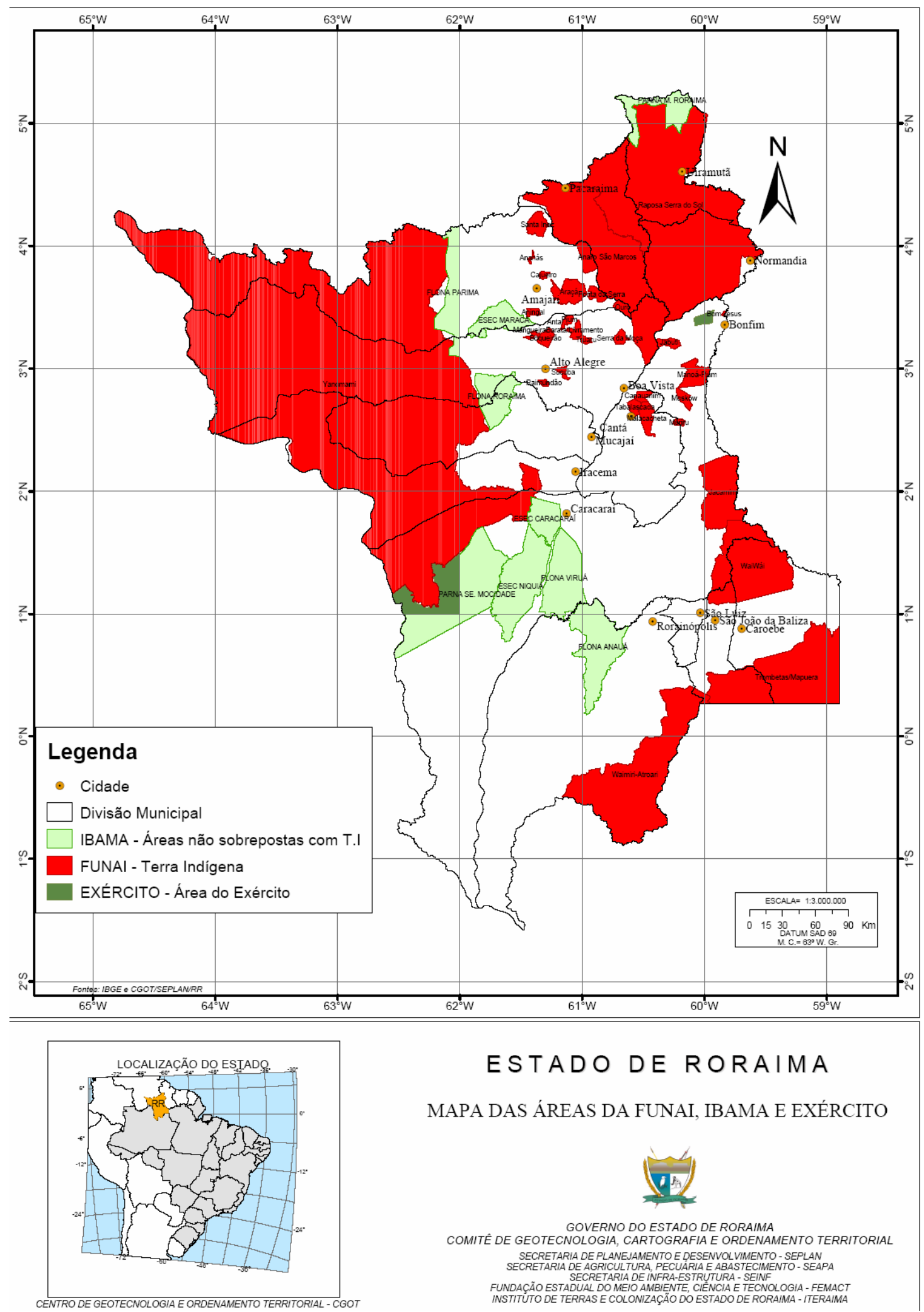

ESTADO DE RORAIMA

MAPA DAS ÁREAS DA FUNAI, IBAMA E EXÉRCITO

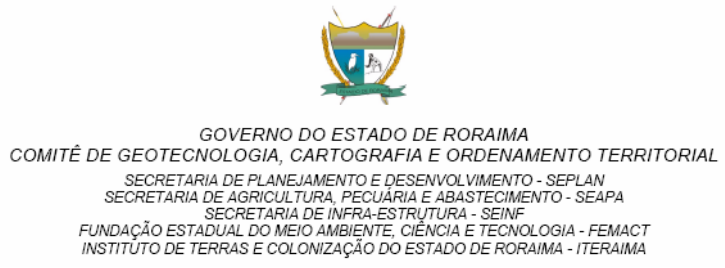


A alternativa que desde os anos 80 foi utilizada pelos governos locais para a inserção do Estado de Roraima aos circuitos produtivos do País foi o fomento à imigração, com distribuição de lotes, além de outras políticas assistencialistas. Foram trazidos imigrantes de vários estados, notadamente do Maranhão, Ceará, Piauí, Rio Grande do Norte, Amazonas, Pará, Rio Grande do Sul, Paraná e Rondônia. Essa nova leva de migrantes veio após campanha publicitária realizada pelo governo do então Território Federal de Roraima, conforme tabela a seguir.

TABELA 5

\begin{tabular}{|c|c|c|c|c|c|}
\hline \multicolumn{5}{|c|}{ Processo migratório e origem dos migrantes para Roraima entre 1996 e 2000} \\
\hline ANO & Pop. & Maranhão & Pará & Amazonas & Outros \\
1996 & 7.687 & 2.662 & 2.329 & 1.742 & 954 \\
1997 & 10.279 & 3.659 & 3.371 & 2.034 & $\mathbf{1 . 2 1 5}$ \\
1998 & 14.835 & 6.818 & 4.065 & 2.490 & 1.462 \\
1999 & 13.034 & 5.830 & 3.767 & 2.106 & 1.331 \\
2000 & 11.078 & 4.684 & 2.768 & 2.245 & 1.381 \\
$\begin{array}{c}\text { TOTAL } \\
\text { Porc/ } \\
\text { Est. }\end{array}$ & 56.913 & 25.653 & 16.300 & 10.617 & 6.343 \\
\hline
\end{tabular}

Fonte: Governo do Estado de Roraima (2001)

No início da década de 80 , já existiam mais de quarenta projetos de colônias agrícolas em processo de implantação em Roraima, o que permitiu a criação de seis municípios de frágil estrutura urbana. A migração para o Estado no final desta década foi impulsionada, no entanto, pelo garimpo, que atraiu para a área Yanomami um contingente estimado em mais de 40.000 garimpeiros.

Com o fechamento do garimpo, pelo então presidente Collor, em 1990, a economia do Estado de RR sofreu um duro golpe, já que a iniciativa privada era (e ainda é) muito incipiente e não pode suportar a falência de diversas empresas e a transferência de estabelecimentos comerciais para outros estados. Foi nesse contexto que o 
crescimento populacional exógeno arrefeceu consideravelmente. (RODRIGUES, 1996:60). A tabela a seguir mostra que o salto que foi dado entre os anos de 1980 e 1990 foi contido na década seguinte.

\section{TABELA 6}

\begin{tabular}{|c|c|c|}
\hline \multicolumn{3}{|c|}{ Crescimento demográfico de Roraima no século XX } \\
\hline Ano & Habitantes/mil & Densidade demográfica/ hab/km² \\
1920 & 7.424 & - \\
1930 & $10.000^{*}$ & - \\
1940 & 10.509 & 0,04 \\
1950 & 18.116 & 0,08 \\
1960 & 28.871 & 0,13 \\
1970 & 40.885 & 0,18 \\
1980 & 79.159 & 0,35 \\
1991 & 217.583 & 0,97 \\
2000 & 324.397 & 1,44 \\
\hline
\end{tabular}

Fontes: *Estimativas do IBGE e Censo Demográfico do Amazonas, 1920 e 1940. Apud. SILVA, P.R.F. (2007:148)

Como reflexo desta dinâmica populacional a economia do Estado de Roraima tem o seu setor terciário ampliado de forma inusitada. O crescimento registrado desde a queda do garimpo só tendeu a aumentar, sendo notada uma pequena reversão desta tendência somente no ano de 2004.

O setor terciário é o mais expressivo na economia roraimense, com destaque para a "administração pública", que possui a maior participação no PIB do Estado. Ainda neste setor, o comércio compreende a maior parte dos empregos existentes no Estado, sobretudo no mercado informal, com participação de trabalhadores nacionais e de países vizinhos.

É importante frisar que a participação da PEA de Roraima no setor terciário tem crescido a cada ano. Se em 1994, compreendia $65,1 \%$, no ano de 2004 , este total atinge 87,4\% do PIB do Estado. Apesar de ter-se mantido com o mesmo valor de 2002 a 2004, o número ainda expressa a forte dependência da União, uma vez que a maior parte desde total é representado por salários pagos aos servidores públicos, em sua maioria servidores federais, conforme, conforme tabela a seguir. 


\section{TABELA 7}

\section{PARTICIPAÇÃO DOS SETORES ECONÔMICOS NA COMPOSIÇÃO DO PIB DE RORAIMA}

(valores em milhões de reais)

\begin{tabular}{|l|l|l|l|l|l|l|l|}
\hline \multicolumn{1}{|c|}{ Ano } & Primário & \multicolumn{1}{c}{$\%$} & Secundário & \% & Terciário & \multicolumn{1}{c|}{ T } & \multicolumn{1}{c|}{ Total } \\
\hline 1994 & 44 & 17,5 & 44 & 17,5 & 164 & 65,1 & 252 \\
\hline 1995 & 54 & 11,7 & 72 & 15,7 & 334 & 72,6 & 460 \\
\hline 1996 & 23 & 4,6 & 86 & 17,1 & 394 & 78,3 & 503 \\
\hline 1997 & 32 & 5,5 & 104 & 18,0 & 441 & 76,4 & 577 \\
\hline 1998 & 27 & 4,0 & 85 & 12,7 & 555 & 83,2 & 667 \\
\hline 1999 & 44 & 6,0 & 91 & 12,3 & 602 & 81,7 & 737 \\
\hline 2000 & 43 & 4,3 & 85 & 8,4 & 883 & 87,3 & 1.011 \\
\hline 2001 & 50 & 4,5 & 98 & 8,8 & 960 & 86,6 & 1.108 \\
\hline 2002 & 56 & 4,0 & 121 & 8,7 & 1.208 & 87,3 & 1.385 \\
\hline 2003 & 55 & 3,5 & 134 & 8,4 & 1.402 & 88,1 & 1.590 \\
\hline 2004 & 66 & 3,79 & 153 & 8,81 & 1.515 & 87,4 & 1.734 \\
\hline
\end{tabular}

FONTE: DEES - Departamento de Estudos Econômicos e Sociais - Seplan, RR, 2004

A existência da Zona Franca de Manaus não tem alterado o quadro acima e ainda não permite uma efetiva complementaridade no comércio regional, haja vista que os produtos chegam sobretaxados e são vendidos a preços exorbitantes no mercado de Boa Vista. Ademais, o comércio local sofre a forte concorrência do comércio mais competitivo de Manaus e da Venezuela.

O setor secundário, por sua vez, teve um forte decréscimo na sua participação que foi de $17,5 \%$, em 1994, e de $8,81 \%$, em 2004. O setor primário, por sua vez, registrou uma situação dramática: despencou de $17,5 \%$ para $3,79 \%$ no período em questão. Aliás, se compararmos a situação histórica de Roraima em relação ao restante do Brasil, ou mesmo à Região Norte, os setores produtivos raramente atingem a casa de $1 \%$, na participação do PIB nacional.

No setor Secundário, tem destaque a industria madeireira e a construção civil, que tem recebido grande impulso com a chegada de novas tecnologias, já presentes em áreas nobres de Boa Vista. Até o início deste milênio, o padrão de construção era basicamente 
único. Não se via cobertura com tijolos de barro, e outras peculiaridades da moderna construção. A presença de novos materiais e tecnologias começa a modificar a paisagem urbana do lugar.

O fato é que ainda são muito tímidos os investimentos de monta no setor industrial. Não há, pois, investimentos que realmente possam interferir no processo produtivo do Estado. O Distrito Industrial conta com cerca de vinte empresas de pequeno e médio portes, as quais ainda não atendem as demandas básicas do Estado. Pretendese que este quadro seja alterado com a implantação de alguns projetos a exemplo do imenso e complexo programa, baseado na exploração agroindustrial da empresa Ouro Verde Agrosilvopastoril, como se verá adiante.

Na última posição encontra-se o setor Primário, cuja produção bovina em décadas recentes chegou a atender parte das demandas do estado do Amazonas. Em 1970, quando a população de Roraima era de 40.885 (TABELA 8), o total de bovinos era de 238 761 cabeças. O Censo Agropecuário de 1996 assinala que o total de bovinos era de 399 939 cabeças, para uma população de 247.131 habitantes. Comparativamente, em 1970 temos um total de bovinos que ultrapassa, em média, cinco vezes o número da população, enquanto em 1996, o total de bovinos não representa sequer o dobro da população.

\section{TABELA 8}

\begin{tabular}{|c|c|c|c|c|c|}
\hline \multicolumn{7}{|c|}{ População urbana e rural em Roraima entre 1950 e 2000} \\
\hline Ano & $\begin{array}{c}\text { População } \\
\text { Urbana }\end{array}$ & $\%$ & $\begin{array}{c}\text { População } \\
\text { Rural }\end{array}$ & $\%$ & $\begin{array}{c}\text { Total da } \\
\text { População }\end{array}$ \\
1950 & 5.132 & 28,33 & 12.984 & 71,67 & 18.116 \\
1960 & 12.460 & 42,92 & 16.411 & 57,08 & 28.871 \\
1970 & 17.481 & 42,76 & 23.404 & 57,24 & 40.885 \\
1980 & 48.734 & 61,56 & 30.425 & 38,44 & 79.159 \\
1991 & 140.818 & 64,72 & 76.765 & 35,28 & 217.583 \\
2000 & 247.016 & 76,11 & 77.381 & 23,89 & 324.397 \\
\hline
\end{tabular}

Fontes: IBGE, Censos Demográficos Roraima. Apud. SILVA, P.R.F. (2007) 
O sub-setor da agricultura registrou crescimento na área da rizicultura e da sojicultura a partir de 1999, após o grande incêndio, de 1998, que destruiu cerca de 7\% da cobertura florestal do Estado ${ }^{30}$. As duas culturas citadas têm encontrado dificuldades para: a primeira por ter sido cultivada, em parte, em área indígena homologada em abril de 2005; e a segunda, por pressões de ambientalistas que apontam na expansão da soja uma grande ameaça aos ambientes naturais. Isso decorre da ausência de políticas claras em vários setores, como o fundiário.

As demais atividades produtivas do setor primário de Roraima ainda são consideradas de subsistência. Não há, num horizonte próximo, projetos que alterem este cenário. Poucas empresas do setor conseguem manter um nível razoável de rentabilidade, a exemplo da Grão Norte, com as monoculturas de arroz e soja, iniciadas em meados da década de 1990.

Outras tentativas, como o cultivo de uva no vale do rio Branco, ainda são bastante incipientes e não abastecem todo o mercado existente. Até o momento, a maior parte das frutas e verduras vem do Sudeste brasileiro.

Ainda no setor primário, a atividade extrativa da madeira em toras, voltada à exportação, mormente, para a Venezuela, sofreu um forte impacto na década de 80 , após a aplicação de sobretaxa imposta pelo governo venezuelano, apesar do forte impulso que este comércio obteve entre os anos de 1968/75.

Espera-se ainda para este setor que o extrativismo vegetal de produtos tradicionais da região também venha a incrementar a produção inexpressiva que se observa na atualidade, em vista das possibilidades de complementaridade na economia regional, com abrangência também aos países vizinhos.

O intercâmbio nas áreas fronteiriças de Pacaraima/Santa Helena e Bonfim/Lethen, no entanto, ainda fazem parte de uma dinâmica de convívio muito pouco formalizada, com iniciativas locais na área de saúde, educação, turismo, além do comércio nas áreas fronteiriças. Predomina o "comércio formiga" de pouca expressão econômica.

Já há alguns anos, uma forte expectativa de crescimento do Estado é alimentada com a possibilidade de se importar petróleo da Venezuela a custos muito menores do que

30 Estimativas do INPA e INPE, apresentam uma variação entre 11 e 13 mil km² de áreas destruídas pelo incêndio no Estado de Roraima. (FGV/ISAE, 
os praticados pela Estatal Petrobrás. Desde que se iniciou o Projeto Guri, a promessa de concretização do comércio do petróleo foi reforçada por parte de políticos locais. No entanto, ainda não se formalizou uma parceria para atender os interesses da comunidade local.

O governo atual vem tentando consolidar alternativas produtivas no Estado quase todas dependentes de forte investimento na área energética. Uma das grandes metas é a autorização para que a empresa estatal de energia de Roraima importe gasolina e diesel da Venezuela. Mas, esta via tem sido negada, tacitamente, pelo governo que não pretende abrir precedente de trocas desta natureza, para benefício de áreas de fronteira.

"Mozarildo Cavalcanti comentou que as articulações em torno das propostas de Roraima para ampliar o intercâmbio com a Venezuela não podem sofrer descontinuidade. Diz o senador: Faremos gestões permanentes junto ao Governo Federal e ao Congresso Nacional, mostrando-Ihes a importância da integração ao futuro do Norte do País". (Folha Boa Vista 28/06/2006)

O mesmo artigo afirma que Ottomar Pinto e Mozarildo Cavalcanti defendem a abertura da fronteira 24 horas por dia. "Hugo Chávez reafirmou a disponibilidade da Venezuela exportar gasolina e diesel a preços diferenciados a Roraima e também defende a abertura ininterrupta da fronteira. "O Brasil precisa fazer a sua parte, pois os acordos vão baratear custos e reforçar o desenvolvimento econômico de Roraima". (Idem)

No quadro de integração regional, o Linhão de Guri, inaugurado em julho/2001 com uma linha de transmissão de $230 \mathrm{KV}$, interligando o Brasil à Venezuela, foi o passo mais audacioso até agora. O contrato de suprimento de energia foi assinado em 1997 entre a Eletronorte e a empresa Venezuela Edelca, com vigência de vinte anos. (FBV, 18/02/2006)

A concessão de serviços de eletricidade no Estado está dividida entre a Boa Vista Energia S/A - BOVESA, que gera e distribui energia elétrica na capital, e a Companhia Energética de Roraima - CER, que supre os demais municípios. (FIGURA 4) 
FIGURA 4

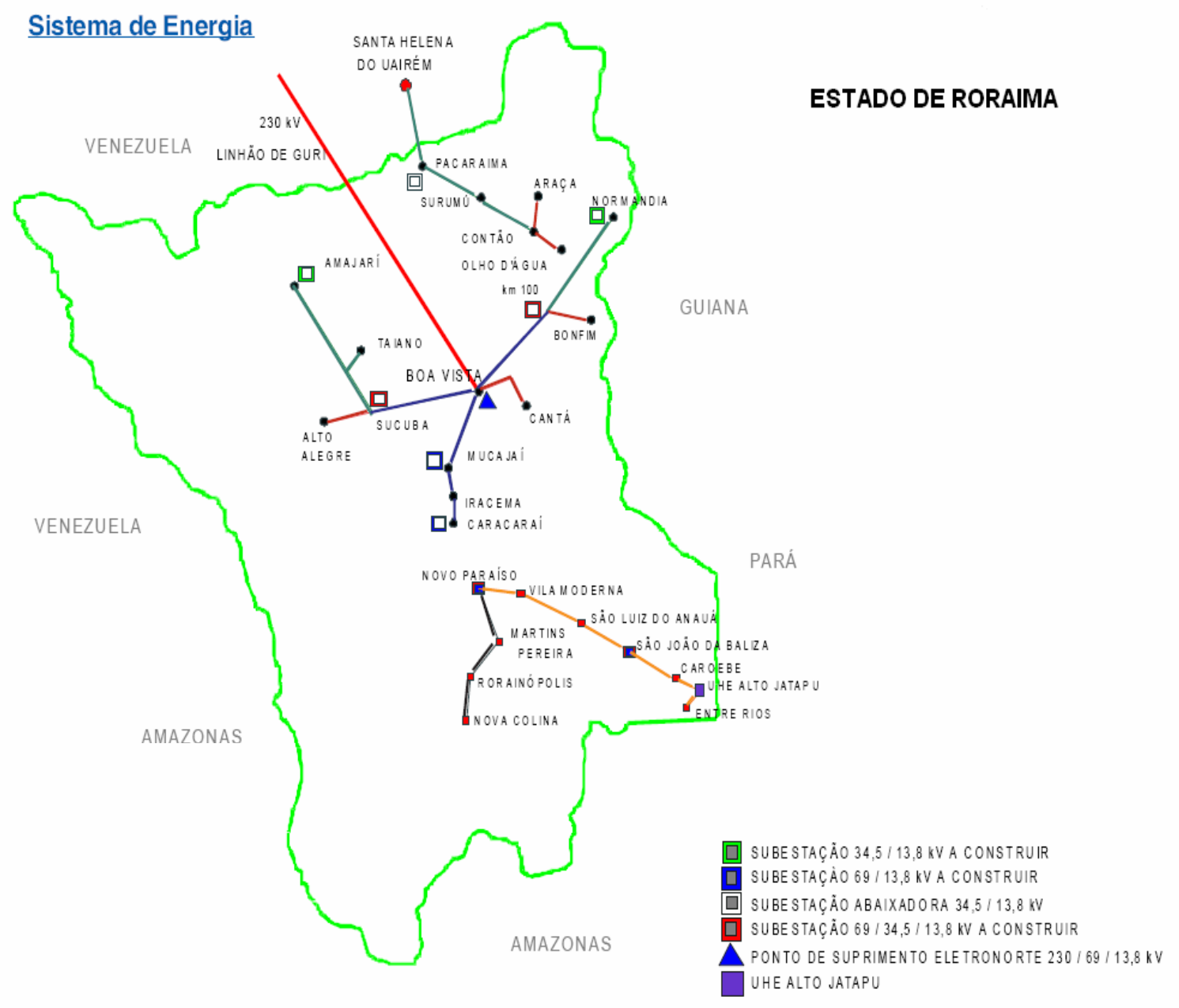

Fonte: PDLIS, 2000, Informaçōes Complementares. 
Todas as iniciativas no eixo da BR-174 terão de passar por definições que envolvem as populações indígenas da área cortada por esta estrada. Nesse sentido, as soluções de consenso com certeza demandarão projetos de médio e longo prazos para a região. Esses projetos terão de ter natureza diferenciada daqueles que têm sido conduzidos sem a participação desses grupos.

Outro foco de atenção do Governo estadual diz respeito à fronteira do Brasil com a Repúbica Federativa da Guiana, que parece ser mais promissor para a realização da Área de Livre Comércio, já aprovada pelo governo federal. Esse novo arranjo econômico deverá promover uma nova dinâmica, não apenas nas áreas dos municípios fronteiriços de Bonfim e Lethen, mas em toda a região, que vai de Manaus à Georgetown na Guiana.

Além de uma eficiente gestão política do assunto, há necessidade de uma infraestrutura para a dinamização deste eixo de integração dos mercados regionais Brasil/Caribe. A ponte do rio Tacutu que liga Bonfim a Lethen, aguarda a mais de um século por sua conclusão. Conforme informações colhidas em palestra proferida pelo representante de Relações Internacionais em Roraima, Sr. Sérgio Pilon ${ }^{31}$, os recursos já foram assegurados.

Também a estrada que interliga Bonfim a Georgetown necessita ser pavimentada no trecho guianense. Além dos recursos já assegurados pelo governo brasileiro, há necessidade de uma complexa negociação com setores da sociedade civil guianense, que apontam os fortes impactos sócio-ambientais na abertura desta área de livre comércio. Esta parece ser a parte mais cara e complexa do projeto.

Outro gargalo neste processo é a ausência de iniciativas locais nos vários setores que farão parte dos acordos bilaterais. Neste sentido há a tendência de que as cidades gêmeas de Bonfim e Lethen sejam transformadas em meras áreas de passagem para os negócios sediados em áreas mais dinâmicas, como São Paulo, Manaus, Caracas e Georgetown.

Chama atenção, por fim, o estabelecimento de um grande empreendimento no Estado, mantido sob a coordenação de um grupo suíço liderado pelos empresários Walter Vogel e seu filho Michel Vogel. O capital deste grupo tem sido estendido a várias setores, que vão desde empreendimento na área de lazer (Haras Cuña Puca), a empreendimentos

31 Palestra realizada no Auditório da UFRR em maio/2007. 
agroindustriais. Estes últimos têm alterado a paisagem local e são visíveis pela ocupação de milhares de hectares de terra ( 30.000 ha na primeira fase) com a plantação de Acácia mangium - uma espécie proveniente da Austrália e até então desconhecida na região.

\begin{abstract}
Amplamente plantada na Ásia, onde é utilizada como matéria prima na produção de polpa, a Acácia Mangium é utilizada ainda para lenha e carvão e como madeira para construção e manufatura de móveis (...).Em regiões úmidas da Costa do Marfim e outros países a Acácia mangium é plantada em consórcio com outras espécies de madeiras nobres, numa proporção de $25 \%$ de acácia para $75 \%$ de madeiras nobres. A função da acácia é proporcionar madeira de menor valor para lenha a curto prazo (5 a 10 anos) (EIA, 2001:7:264 e 269)
\end{abstract}

A área de influência indireta do empreendimento foi estimada em $14,89 \%$ da área total do Estado, com abrangência dos municípios de Boa Vista, Bonfim, Cantá e Mucajaí. $27 \%$ deste total abrange áreas com populações indígenas que residem em seu entorno e que dependem dos recursos naturais existentes na área para manter sua sobrevivência.

A área de influência direta (AID), que abrange a área total das propriedades vinculadas atualmente à Ouro Verde Agrosilvopastoril, é uma área descontínua nos quatro municípios citados, perfazendo um total de 55.376 ha. E, a área a ser incorporada à AID é de 21.624 ha, perfazendo uma área total de 77.000 ha. Estima-se uma utilização de $39 \%$ da área total das propriedades para plantio, sendo o restante representado pelas áreas de Reserva Legal (50\%), Preservação Permanente (6\%) e estradas/aceiros/infraestrutura (5\%). (EIA/2001)

As propriedades rurais vinculadas ao empreendimento pertencem a várias empresas e pessoas físicas, sendo a Ouro Verde Agrosilvopastoril a administradora do empreendimento. Tendo em vista as dificuldades na regularização de terras em Roraima, é fácil perceber o forte aparato jurídico que seus investidores têm conseguido mobilizar para conseguir dispor de tão grande área no Estado. (TABELA 9) 


\section{TABELA 9}

Áreas de influência da Ouro Verde Agrosilvopastoril

9.1 Área de influência indireta do empreendimento - All

\begin{tabular}{|l|r|r|r|r|}
\hline \multirow{2}{*}{ Município } & \multicolumn{2}{|c|}{ Área } & \multicolumn{2}{c|}{$\%$} \\
\cline { 2 - 5 } Boa Vista & \multicolumn{1}{c|}{$\mathbf{K m}^{\mathbf{2}}$} & \multicolumn{1}{c|}{ ha } & \multicolumn{1}{c|}{ All } & \multicolumn{1}{c|}{ Estado } \\
Bonfim & $5.686,7$ & 568.670 & 17,04 & $\mathbf{2 , 5 4}$ \\
Cantá & $8.095,5$ & 809.550 & 24,26 & $\mathbf{3 , 6 1}$ \\
Mucajaí & $7.656,9$ & 765.690 & 22,95 & $\mathbf{3 , 4 2}$ \\
Total & $11.928,4$ & 1.192 .840 & 35,75 & $\mathbf{5 , 3 2}$ \\
\hline
\end{tabular}

9.2 Área de influência direta do empreendimento - AID

\begin{tabular}{|l|rr|r|r|}
\hline \multicolumn{1}{|c|}{ Município } & \multicolumn{2}{|c|}{ Área } & \multicolumn{2}{c|}{$\%$} \\
\cline { 2 - 5 } Boa Vista & Há & AID & Estado \\
Bonfim & & 19.369 & 35,0 & $\mathbf{3 , 5}$ \\
Cantá & & 16.918 & 30,6 & $\mathbf{1 , 6 8}$ \\
Mucajaí & & 16.382 & 29,6 & $\mathbf{1 , 6 8}$ \\
Total & & 2.705 & 4,9 & $\mathbf{1 , 6 8}$ \\
\hline
\end{tabular}

Fonte: STCP Engenharia de projetos Ltda, Estudo de Impacto Ambiental/EIA da empresa Ouro Verde Agrosilvopastoril (2001:5:17). 
A proposta mais difundida deste mega-investimento é de utilização da Acácia Mangium para a produção de celulose, que segundo especialistas é tão boa quanto os melhores eucaliptos utilizados atualmente. No entanto, desde o início do projeto, em 1999, até agora, nenhuma indústria de celulose foi instalada. Talvez isso esteja acontecendo em função do período de colheita, estimada para ocorrer em sete anos.

Em termos de custos do investimento, encontramos no estudo em questão o valor de $\mathrm{R} \$ 2.067$ por hectare, durante a implantação. O custo total de manutenção, pelos sete anos, é estimado em $\mathrm{R} \$ 4$. 000/ha, uma vez que a cada ano o valor de manutenção diminui. Em seguida, o estudo mostra que, agregando-se o valor da colheita e do transporte, por um período de sete anos, para os 30.000 ha projetados, o valor seria de $\mathrm{R} \$$ 70.686.000. No quadro de evolução dos custos no período de 1999-2010, o valor estimado foi de $R \$ 190.084 .500$. A estimativa de receita pela execução do projeto é de $R \$$ 337 milhões, considerando o preço médio de mercado para a madeira. (EIA, 2001:6:47)

O grande argumento apresentado por seus idealizadores para um projeto desta envergadura é a ausência de alternativas econômicas no Estado. Pretende-se que a empresa supra com madeiras as indústrias da região (ainda inexistentes para esta monta!), que gere novecentos empregos diretos e cerca de quatro empregos indiretos para cada emprego direto.

As informações a respeito deste investimento são esparsas e contraditórias e o debate na sociedade é inexistente, apesar da aprovação do EIA/Rima pelo Ministério Público. Isso ocorre porque somente toma parte nesta discussão um seleto grupo de técnicos, detendo-se em aspectos aprioristicamente selecionados, segundo uma concepção interna ao grupo.

É assim que o estudo apresenta centenas de páginas sobre todos os tipos de espécies da flora e da fauna, tipos de solos, dentre outras características do espaço físico que puderam ser inventariadas pela equipe que realizou o estudo. Com relação à sociedade não há aprofundamento suficiente para uma avaliação dos impactos causados pelo empreendimento. Nesses estudos, temos sempre a impressão, pela atenção dedicada a cada espécie vegetal, a cada animal, a cada rocha, que a sociedade em si é apenas um elemento de acomodação na estrutura geral, concebida a milhas de distância dos verdadeiros atores do processo.

$\mathrm{Na}$ parte sócio-econômica, não obstante o farto levantamento de dados estatísticos, não há análise em relação aos resultados de grandes projetos desta 
natureza, já implantados na Amazônia. Não encontramos nenhuma referência às famosas Company Town, verdadeiros quistos de segregação social, que ficaram sem função após o fracasso das iniciativas. Cidades estas tão pobres quantos as demais cidades do interior da Amazônia.

Toda a preocupação do estudo parece residir nos danos ambientais, para os quais são apresentadas todos os tipos de medidas mitigatórias, chegando-se à conclusão que a espécie exótica, na verdade, permitirá um maior grau de infiltração de água no subsolo, maior controle à erosão, e absorção de carbono. Em relação a este último aspecto, possivelmente, segundo especulações locais, resida um dos maiores interesses do grupo empreendedor

Estima-se um incremento médio de Acácia mangium de $20 \mathrm{~m}^{3} / \mathrm{há} / \mathrm{ano}$, representando uma absorção de 5,85 tC/ha/ano. O projeto de florestamento conta, (ano de 2001) com 5.200 ha de florestamento implantado, foi previsto um plantio anual de 3.000 ha desta espécie." Isto significa que atualmente teríamos, em torno de 20.000 ha, cremos porém que esta meta não foi alcançada, em vista, inclusive de pragas e doenças que parecem ter ameaçado as plantações.

A grande ênfase no EIA/RIMA dedicada à absorção do carbono sugere que este venha a ser um dos principais objetivos do projeto. Trata-se de um "negócio da China" para os empresários, se analisarmos a relação custo/benefício, pois calcula-se que o valor que o "seqüestro de carbono" poderá obter nas próximas décadas, tende a ser cada vez maior. A Ouro Verde estipula para seus investimentos um aumento de carbono na ordem de aproximadamente, 17,5 tC/ano. Considerando-se uma área implantada de 27.000 ha total, a absorção anual de carbono seria de 157.950 toneladas.

Segundo LOHMANN, existe atualmente um excesso de carbono na atmosfera de 170 bilhões de toneladas ${ }^{32}$. Desta forma o florestamento pretendido pela Ouro Verde teria uma colaboração de 0,0006 na diminuição do excesso atual de gás carbono existente na atmosfera terrestre. Este percentual é significativo considerado ser um único empreendimento de uma empresa particular. Os resultados são mais significativos ao se considerar que a quantidade de carbono absorvida anualmente pelo florestamento (157.950 tC em 27.000 há) equivale a $6,7 \%$ da emissão total de carbono (na queima) nas formações de Savana do Estado de Roraima (2,35 milhões de tC) (EIA, 2001:286)

\footnotetext{
32 O Brasil é responsável por cerca de 4,5\% das emissões globais de carbono, e cerca de 17,5\% do total das emissões exclusivas provocadas pela troca do uso da terra. E, do total emitido pelo Brasil, cerca de $80 \%$ provém de alterações antrópicas nos sistemas amazônicos (EIA, 2001:283)
} 
Neste sentido, não parece absurdo supor que, no final das contas, o próprio governo brasileiro tenha que pagar pelo "benefício" concedido pela empresa estrangeira. Neste tipo de projeto, como sempre aconteceu na Amazônia, também não existem mecanismos efetivos de captação de recursos por parte dos governos locais. Por mais que se detalhem os projetos, o ônus da fiscalização é pesado demais para a inércia que se observa no Estado.

Um outro aspecto crucial para a discussão que se trava em âmbito nacional diz respeito à proteção do conhecimento e da própria biodiversidade da Amazônia. Para uma área que tem a dimensão que estamos considerando, obviamente, há registro de inúmeros eventos no ecossistema que deveriam compor um campo específico de estudo e realização de experiências, sob a coordenação do governo brasileiro.

Os peritos que elaboraram o estudo parecem não ter-se preocupado com esta questão. Assim é que, em toda a metodologia proposta no chamado Subprograma "Usos potenciais de espécies nativas", não há menção à participação de universidades e laboratórios nacionais na efetiva condução do processo. Há apenas uma referência vaga à participação de "instituições de pesquisa interessadas em estudar e processar o material coletado", que inclui análise química das propriedades terapêuticas de espécies com potencial para uso medicinal (...)"33 (EIA, 2002:9:15).

O assunto não se esgota aqui e temos consciência de que haveria muito mais a dizer sobre as recentes iniciativas de inserção do Estado à economia do País e aos novos signos da modernidade definidos para esta área. Na próxima seção, estenderemos a análise a programas e projetos protagonizados por militares, vinculados aos recentes processos de estruturação do Estado de Roraima, sinteticamente descritos acima.

33 O que parece mais incongruente é que no discurso ambiental assumido pelo governo, a questão da "proteção ao conhecimento e à biodiversidade" é ainda um dos mitos intocáveis, quando na prática a venda do conhecimento já se efetivou, sem nenhum controle do governo. Não estamos, obviamente, assumindo que práticas de cooperação nesta área não deva existir. Devem e precisam ser implementadas, através de um debate aberto com a sociedade. Necessitamos de tecnologias disponíveis em países mais avançados tecnologicamente, mas precisamos de ter controle de todo o processo. 


\section{II.3 Os desdobramentos de programas e projetos protagonizados por militares}

O novo cenário estratégico da geopolítica amazônica tem sido caracterizado por vários fatores: pela ampliação de bases militares na região; pela realização de operações conjuntas e do emprego integrado das três forças; intensificação da participação das Forças Armadas em várias ações de cunho social e; ainda, pelo estabelecimento de uma parceria mais estreita com órgãos e instituições públicas e com outras instituições que atuam na Amazônia.

Demonstraremos nesta seção como os programas protagonizados pelas Forças Armadas, quais sejam Calha Norte, Sivam e Sipam, apesar de toda polêmica gerada ${ }^{34} \mathrm{e}$ da contestação veemente de alguns setores, vêm atendendo a demandas sociais e confundindo cada vez mais a geografia do poder local.

Tomando como base os relatórios de execução orçamentária do Ministério da Defesa $^{35}$; as notícias veiculadas através da imprensa; os depoimentos de alguns políticos e parlamentares; os websites oficiais relativos a esses programas; a literatura existente sobre o tema; além de depoimentos colhidos em alguns órgãos e com lideranças locais, sobretudo em Boa Vista, sintetizamos alguns aspectos referentes a esses programas que nos parecem interessantes para o debate relativo à gestão política em algumas áreas da Amazônia, notadamente, no Estado de Roraima.

Os Relatórios das ações dos PPAs, implementadas pelo Ministério da Defesa, até o ano de 2005, são importantes instrumentos para nossa análise, pois trazem informações detalhadas das atividades que foram levadas adiante por este setor e que não se encontram disponíveis no âmbitos da consulta local.

Esclarecemos todavia que esses documentos apresentam sempre a visão oficial e propagandística do governo. No entanto, nossa intenção aqui não é de fazer uma análise crítica dos documentos divulgados, menos ainda apologética destes programas. Pretendemos, outrossim, analisá-los enquanto fenômeno que se manifesta de forma concreta nas áreas visitadas.

\footnotetext{
$34 \quad$ As polêmicas principais referiram-se ao caráter sigiloso que cercou esses programas; ao montante de recursos que os envolvem; à ausência de participação da comunidade científica e da sociedade civil, de modo geral, na sua elaboração, com todas as consequiências que isso acarreta. No caso do Sivam, além dos aspectos citados, contestou-se também a sofisticação de instrumentos e recursos humanos para operar o sistema, e a forma de licitação, e escolha da empresa americana Raytheon, para repasse de tecnologias. A bibliografia a respeito do tema é extensa, a exemplo da dissertação de mestrado de LOURENÇÃO, H. (2003).

Relatórios apresentados pelo MD, relativos ao PPA 2000/2003, e os resultados alcançados até 2005, do PPA 2004/2007. Brasil, 2003 e 2005, respectivamente.
} 


\section{II.4 A metamorfose do Programa Calha Norte}

Os PPAs são utilizados na nossa análise para mostrar a evolução e expansão de atividades do Programa Calha Norte ao longo dos anos de sua existência. Apresentamos o aporte de recursos, que foi sendo ampliado gradativamente, nos últimos anos, após longo tempo de estagnação e indecisão em relação ao seu futuro.

Concebido durante o governo Sarney, em 1985, o Programa visava a abranger três áreas geográficas com características peculiares: a faixa de fronteira ${ }^{36}$; a faixa ribeirinha, que compreende a calha dos rios Solimões/Amazonas, e a faixa interior, denominada hinterlândia, situada entre as duas primeiras.

\section{FIGURA 5}

Área atual do Calha Norte

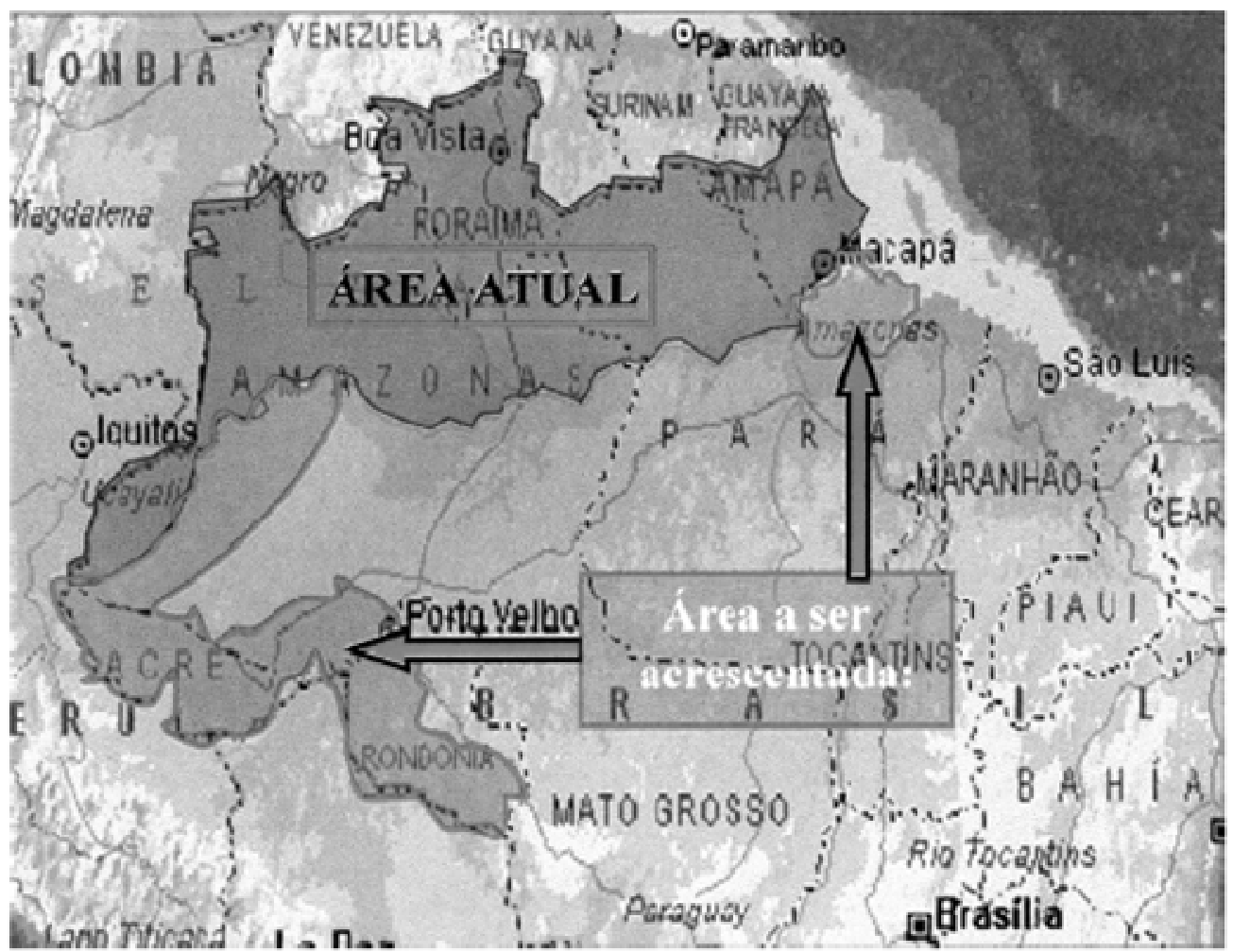

Obs: As áreas apontadas com a seta já foram incorporadas ao PCN

Fonte: PCN, Ministério da Defesa, 2003

\footnotetext{
$36 \quad$ A Faixa de Fronteira é a área, de $150 \mathrm{~km}$ de largura, paralela à linha terrestre divisória do Brasil com os países limítrofes (Lei $\mathrm{n}^{\circ}$ 6.634, de 02 de maio de 1979, regulamentada pelo Decreto $\mathrm{n}^{\circ}$ 85.064, de 26 de agosto de 1980).
} 
Até janeiro de 2004, o PCN abrangia 74 municípios, 41 deles situados total ou parcialmente na Faixa de Fronteira, numa área que se estendia da calha dos Rios Amazonas e Solimões até a fronteira setentrional do Brasil. Atualmente o projeto foi estendido para a faixa noroeste abrangendo o Estado do Acre e grande parte do Estado de Rondônia, conforme figura acima.

A justificativa apresentada para a intervenção nessas áreas foi a carência de infraestrutura e de ações do governo, além da existência de ilícitos de várias ordens, na fronteira com os países amazônicos. A "faixa de fronteira" é destacada como mais vulnerável e emergencial para a implantação das ações do $\mathrm{PCN}$, como se pode notar no trecho que segue:

A ameaça de ocupação internacional da floresta já alimenta os projetos das
forças armadas há muitos anos. Entre os argumentos apresentados pela
Secretaria Geral do Conselho de Segurança Nacional para a criação do Projeto
Calha Norte, em 1985, por exemplo, estavam: a cobiça internacional dos
recursos minerais existentes na região; o crescente trânsito ilegal de
estrangeiros; a instabilidade interna nos países vizinhos; a intensificação dos
conflitos de terras; e pressões (internas e, sobretudo, externas) para criação de
reservas indígenas em áreas ricas de minérios e na faixa de fronteira."
(CAVAGNARI FILHO, 1994)

Como resposta a essas supostas ameaças, após 2003, as Forças Armadas passaram a concentrar esforços na implantação e na manutenção de infra-estrutura em municípios fronteiriços e em Pelotões de Fronteira. Isso não significa, entretanto, o restabelecimento da antiga idéia de "vivificação da fronteira", enquanto ocupação e fixação do povoamento, pois os parâmetros atuais de sustentabilidade ambiental colocam a Amazônia num outro patamar de segurança estratégica, que implica uma nova concepção de uso do território.

Assim, ainda que a maior parte dos investimentos do PCN tenham sido direcionados para a manutenção e para a melhoria da infra-estrutura; para a construção de micro-usinas de energia elétrica; para a construção e a manutenção de portos, de aeroportos e de rodovias; além do investimento na segurança da navegação fluvial, a definição de prioridades tem sido feita a partir de demandas locais. Esse novo cenário é caracterizado pela inclusão de novos atores, antes não contemplados nos planos e programas elaborados para a Amazônia.

De especial importância é a participação direta e indireta desses atores nas ações de saúde voltadas para as populações indígenas e comunidades carentes, dentre outras ações sociais. Essas ações fazem do PCN um importante instrumento de gestão da 
política regional, tanto por sua abrangência quanto pela sua presença quase única em áreas de difícil acesso. Isso sobressai, quando se considera que pouquíssimas instituições do governo brasileiro atuam nessas áreas.

A partir de 2004, o PCN foi estendido para além da faixa ribeirinha e da calha do rio Solimões/Amazonas Essa nova área de abrangência corresponde a toda a faixa fronteiriça desde a llha de Marajó, no Pará, até os limites do Estado de Rondônia com o Estado do Mato Grosso, num total de 2.186 .252 km², conforme a Figura 4.

O Calha Norte é bastante significativo por abranger, atualmente, cento e cinqüenta e um municípios, sendo noventa e cinco localizados na faixa de fronteira de seis Estados da Federação, "com uma população de cerca de 5.300.000, aí incluindo 30\% da população indígena do Brasil." (BRASIL, 2005). Nesse sentido, pode-se dizer que no Calha Norte há uma política de base territorial mais nítida que em outros projetos de escopo regional, mais pautadas em temas específicos de segurança e defesa

Em relação aos recursos envolvidos no PCN, o total de recursos aplicados até o ano de 2006 é de cerca de US\$325.825.000,00, conforme GRÁFICO 1, a seguir.

\section{GRÁFICO 1}

\section{Recursos recebidos pelo $\mathrm{PCN}$}



Fonte: Website do Ministério da Defesa. Acesso em 20/01/2007³

37 Os valores apresentados referem-se ao montante recebido ao longo dos anos. O total de recursos aplicados no período considerado é de cerca de US\$325.825.000,00. 
Deve-se destacar que o aporte de recurso no início foi bastante significativo. Nessa época conseguiu-se preparar boa parte da infra-estrutura do Projeto. Em contraste, nos dez anos subseqüentes, que corresponde à década de 90 , como mostra o quadro, o Programa ficou praticamente sem nenhuma capacidade de realização financeira, vindo começar a se recuperar somente a partir de 2000 , alcançando seu maior empenho, nos anos de 2005 e 2006.

Por outro lado, ainda que tenha recebido recursos orçamentários substanciais, os mesmos não foram liberados em sua totalidade. Diz ainda o Relatório do PPA/2005 que "os projetos sofreram forte contingenciamento na implantação da Infra-estrutura básica nos municípios (...) que teve cerca de $97 \%$ de seus recursos oriundos de emendas parlamentares ${ }^{38}$, e somente $40 \%$ dos recursos liberados."

A exemplo do que vem sendo realizado no âmbito do PCN, destacamos abaixo algumas ações e custos, até o ano de 2003, conforme relatório do Ministério da Defesa:

- Apoio aéreo na Região da Calha Norte - tem por finalidade complementar o apoio logístico às unidades militares da região e prestar serviço humanitário às comunidades. Foram descentralizados para os Comandos todos os recursos previstos nesta ação na LOA 2003(R\$ 703.324,00;

- Apoio às Comunidades da Região da Calha Norte. Foi repassado nesta ação o valor total previsto na LOA 2003, $\mathrm{R} \$ 757.540,00$;

- Conservação de Rodovias na Região da Calha Norte. Foi repassado o valor total previsto na LOA 2003, R\$549.032,00. Estes recursos foram utilizados na conservação da rodovia federal BR-307 no trecho de 220 Km, que liga a sede do município de São Gabriel da Cachoeira/AM à localidade de Cucuí, no mesmo município e no trecho da rodovia que liga as localidades de Surumu/RR à Uiramutã/RR, num total de $50 \mathrm{~km}$ de rodovias;

- Manutenção de infra-estrutura dos Pelotões Especiais de Fronteira. Foram repassados R\$ 799.999,70 nesta ação. Estava prevista a manutenção de três Pelotões Especiais de Fronteira, porém foram mantidos nove Pelotões Especiais de Fronteira durante o ano de 2003, superando a meta inicialmente estabelecida;

- Implantação de Unidades Militares na Região da Calha Norte. Foi repassado o valor de R\$ 3.993.310,98 para os três Comandos Militares nesta ação. Dentre as principais realizações militares citamos: mudança da sede do Comando Naval da Amazônia Ocidental em Manaus-AM; entrada em operação de três novos Pelotões Especiais de Fronteira localizados em Tunuí-Cachoeira-AM, Uiramutã-RR e Tiriós-PA; Inauguração da primeira fase da Implantação do núcleo da Base Aérea de São Gabriel da Cachoeira, no estado do Amazonas; Construção de um novo Quartel em Vila Bittencourt (fronteira com a Colômbia); Novas Instalações Militares em Cucuí-AM; e Construção da Companhia de Forças Especiais em Manaus-AM.

38

Se compararmos com o Gráfico 1 percebemos que ali constam apenas 5.000 milhões de recursos recebidos pelo PCN em 2003 mas, no PPA, destaca-se que neste ano somente foram empenhados créditos, neste Programa, no valor total de R \$ 42,3 milhões. O valor necessário, conforme o planejamento inicial, era de R\$ 430,9 milhões." Daí se deduz que o restante do recurso seja proveniente de outras fontes, como as emendas parlamentares, citadas acima. 
O PCN altera, desta maneira, a paisagem local, sobretudo pelas obras de concretude espacial que se dá em certas áreas carentes de infra-estrutura. No Estado de Roraima, foram realizadas a construção de um posto de saúde na cidade de Uiramutã/RR; a rede de distribuição elétrica no município de Bonfim/RR; a rede elétrica e iluminação pública no município de Iracema/RR; a construção de uma biblioteca pública no município de Iracema/RR; a construção de oitenta abrigos para passageiros de transportes coletivos no município de Boa Vista/RR; a construção de um posto médico no município de Mucajaí/RR, além de uma série de novas obras iniciadas após 2004.

No PPA 2003, percebe-se que a maior parte dos recursos gastos em obras foram empregados no Estado de Roraima. Isso talvez tenha ocorrido em função dos diagnósticos realizados durante a elaboração dos PDLIS ${ }^{39}$; do envolvimento e da cobrança feita pelas lideranças locais, e; ainda, da própria definição estratégica de prioridades estabelecidas no desenho do Programa.

Por outro lado, ainda se deve considerar as parcerias realizadas com estados e municípios. Assim, na avaliação de custos também deve ser levado em conta o fato de que nem tudo que tenha a marca do PCN recebeu verbas oriundas diretamente deste programa, como atesta o trecho abaixo reproduzido:

É pertinente ressaltar que o Programa Calha Norte, embora disponha de recursos próprios para financiar programas e projetos em sua área de atuação, é essencialmente uma instância de articulação de órgãos e entidades públicas federais, regionais, estaduais, municipais - e um agente catalisador das empresas privadas e organizações comunitárias, na medida em que busca implementar decisões e canalizar recursos de múltiplas fontes para programas e projetos do interesse do desenvolvimento norte-amazônico. (MD, PDLIS, 2000)

Como resultado dos estudos feitos sobre as articulações citadas, dos seminários, e de pesquisas in loco, chegou-se a um diagnóstico dos municípios da Calha Norte, que são os próprios PDLIS - incorporados ao programa Avança Brasil do governo FHC, (1999-2002). Para fazer o diagnóstico foi feita uma parceria com a Fundação Getúlio Vargas.

Nestes planos, a tônica do desenvolvimento sustentável está alicerçada numa visão de crescimento interna e articulada com as unidades da Federação. O objetivo é o

\footnotetext{
39 Planos de Desenvolvimento Local, Integrado e Sustentável. Concebidos no final do primeiro mandado de FHC. Para muitos autores uma espécie de plataforma eleitoreira para a reeleição presidencial, que ocorreu em 1998. Com a vitória, o PSDB incorporou a proposta dos PDLIS ao programa de governo oficial, intitulado "Avança Brasil", do mandato subseqüente.
} 
de se garantir uma maior inserção competitiva do país no cenário internacional, passando por elos regionais. Como aponta COSTA

Nesta última década, um conjunto expressivo de políticas públicas brasileiras, agora não mais exclusivamente estatais e crescentemente descentralizadas, têm contribuído para o atual processo de rearticulação na escala do sub-continente, expresso sobretudo pela diversificação e a intensificação dos fluxos, pelo novo significado das relações de vizinhança e os enlaces especificamente fronteiriços, e pela entrada em operação e funcionamento dos diversos tipos e níveis de redes que têm aproximado lugares e alterado a sua posição relativa. O poder de mobilização de algumas dessas políticas, especialmente pelas suas magnitude e capacidade de deflagrar movimentos de longo alcance, qualifica-as como os novos vetores das mudanças em curso (Becker, 1994,1997), numa escala que é provavelmente pela primeira vez na história, sub-continental de fato. (COSTA, 1996)

Apesar deste modelo ter sido apreciado por vários setores ${ }^{40}$, a concretização das propostas esbarravam em uma série de condicionantes, que começavam com a dificuldade em aglutinar interesses tão divergentes presentes nos municípios fronteiriços e os três níveis da administração pública: o federal, o estadual e o municipal, as mais das vezes, entendidos como injunção do poder da União sobre o poder local. Conforme Milton Santos, trata-se de uma "verticalidade", que se expressa pela imposição de políticas desvinculadas da realidade local. (SANTOS, 1996)

Outro problema central diz respeito à descontinuidade de ações, que para serem concluídas necessitam sempre de um período maior do que o estabelecido para os mandatos dos candidatos eleitos. Ainda outro descompasso dessas propostas é que ações "modernizadoras" exigem capacidade de execução, tanto em termos de gestão eficiente; como de infra-estrutura instalada e recursos humanos, quase nunca disponíveis em localidades mais isoladas do contexto nacional.

Deve-se considerar também a temporalidade presente na Amazônia. Um rápido olhar sobre as cidades nos revelam que, em muitos aspectos, estamos diante de um "universo lento", com algumas práticas características das primeiras décadas do século $X X$, quando o país ainda não tinha aderido à modernização que se observa hoje em cidades maiores.

\footnotetext{
$40 \quad$ Em alguns municípios visitados, em Roraima, algumas lideranças afirmaram, que os PDLIS, inicialmente foram vistos com muito entusiasmo pela população local. "Eles estavam aglutinando pessoas, e parecia que esta parte do Brasil, estava sendo lembrada", disse o representante da Associação Comercial de Pacaraima, Sr. Severo Messias, em entrevista concedida a autora.
} 
Por outro lado, deve ser considerado o verdadeiro "choque de temporalidade" que se observa em espaços pontuais dotados de alta tecnologia, ocupados por autores hegemônicos, dispersos até mesmo na "selva" mais recôndita. ${ }^{41}$

Os resultados dos diagnósticos dos PDLIS disponíveis em alguns órgãos da administração pública dos municípios da Calha Norte permitem chegar a alguns dados importantes sobre essas localidades, tendo em vista as dificuldades de se encontrar estudos mais detalhados sobre a realidade de municípios fronteiriços. ${ }^{42}$

Ainda que a apresentação dos objetivos dos PDLIS tenha sido homogeneizada para todos os municípios e a ênfase no desenvolvimento sustentável permaneça muito genérica em relação aos problemas específicos de cada município, pôde-se, à luz desses estudos conversar com algumas lideranças e averiguar o processo de discussão que ocorreu ou deixou de ocorrer com os atores locais. ${ }^{43}$

A tônica da modernização da gestão pública e o interesse em colocar os municípios fronteiriços em compasso com a realidade do País, torná-los mais dinâmicos e inseridos no contexto global, geraram sérios antagonismos em setores avessos à inserção de comunidades distantes ou isoladas à modernidade, que se expressa através de obras de infra-estrutura; de acordos de cooperação entre países fronteiriços; de incentivo ao comércio, dentre outros elementos presentes na proposta dos PDLIS. ${ }^{44}$

No caso do "Diagnóstico Participativo Local do Município de Pacaraima", não foi feita nenhuma menção à participação de lideranças indígenas em sua elaboração, Ao contrário, são ressaltados os entraves ocasionados pela demarcação de áreas

\footnotetext{
41 São exemplos os "hotéis de selva" que já incorporam equipamentos sofisticados; empresas modernas e equipadas para atender o público de alta renda que circula por essas áreas; o próprio SIVAM/SIPAM, com capacidade já instalada para atuar em alguns pontos, estendendo suas redes de modernidade a áreas isoladas.

42 Muitas das ações propostas foram realizadas, como destacamos aqui, outras ainda estão em implementação ou foram modificadas, em função de novas políticas, estabelecidas pelo governo Lula, ou em função da morosidade da chegada de recursos.

43 É interessante destacar, no caso de Pacaraima, a elaboração de várias etapas de discussão local, chegando-se a um documento, que pretendia-se fosse registrado em cartório, como uma espécie de protocolo de intenções que deveriam ser levadas adiante pelo município. O Sebrae ofereceu todo o apoio à iniciativa, que, segundo depoimento do gerente municipal do Programa Peti, que o coordenou, Sr. Emival G. Nascimento, foi abortada, a partir de 2003, com o fechamento das sedes do PDLIS nos municípios roraimenses.

$44 \quad \mathrm{Na}$ apresentação de cada PDLIS, alerta-se que esse documento "deverá ser entendido como uma agenda executiva das ações de desenvolvimento, fomento e ordenamento das múltiplas atividades que se processam no espaço geo-econômico-social do Município”. (Ministério da Defesa, 1999)
} 
indígenas ${ }^{45}$ para o desenvolvimento local. Assim é que, na "matriz de problemas" do referido Diagnóstico, destacam-se como aspectos de "ordem externa": a atuação de Ongs e a cobiça internacional, apontados como entrave ao desenvolvimento do município, por sua capacidade de influenciar políticas locais. ${ }^{46}$

Em entrevista realizada com algumas lideranças dos municípios de Pacaraima, Bonfim, Boa Vista e Normandia ${ }^{47}$, se pôde averiguar a aceitação das propostas do PCN claramente voltadas à inserção competitiva e à integração econômica das comunidades e dos povos indígenas ao resto do país. Obviamente, chegamos a resultados pouco alentadores em relação à possibilidade de conciliação dos inúmeros interesses existentes. Até a presente data, ainda não se chegou, por exemplo, a uma solução definitiva em relação aos arrozeiros, que possuem suas plantações na área indígena Raposa/Serra do Sol, homologada, desde abril/2005.

Programas como o PCN trazem um grande apelo ao desenvolvimento e à modernização do local, por buscarem convergência com outras políticas, como aquelas que dizem respeito às comunidades indígenas. E, neste caso, no que concerne ao Estado de Roraima, não há ainda um consenso em relação à aceitação dessas políticas, nem no interior de grupos denominados "integrados" nem daqueles que propõem outras formas de utilização dos territórios homologados. Todos sabem que essas "novas formas" são grandes incógnitas em termos de aplicabilidade e de resultados concretos e positivos para as comunidades envolvidas.

Em relação ao rol de atores e de instituições envolvidas com a gestão sócioeconômica de Roraima, é importante destacar as recentes tentativas do setor militar de se aproximar de outros órgãos públicos e de instituições da sociedade civil que lidam com a questão indígena, não apenas no âmbito da Calha Norte, como também no que concerne ao Sivam e Sipam.

\footnotetext{
$45 \quad \mathrm{O}$ município está localizado na área indígena São Marcos. E, menos de $2 \%$ de sua área é urbana, existindo negociações para que esta área seja excluída da área indígena, por estar localizada no único ponto da BR-174, que se conecta com a Venezuela.

46 Conforme documento (mimeo) cedido pelo Sr. Emival, encarregado de sintetizar as propostas provenientes do município de Pacaraima.

Durante nossa investigação, tivemos que nos concentrar em poucas áreas do Estado de Roraima. Um dos critérios utilizados foi a prioridade aos municípios onde existem os PEFs, e no caso de Boa Vista, por ser a sede que aglutina as instituições de expressão no Estado, além de ser o espaço por onde passam os atores hegemônicos que detêm dados, informações e o poder no Estado.
} 
Ao que parece, os militares redefiniram sua estratégia de "incorporação do nativo à comunhão nacional"48 e perceberam, afinal, que a indianidade é um elemento de importância à própria manutenção e expansão da presença militar em áreas indígenas, na medida em que o discurso relativo à segurança e defesa dessas áreas são aceitos pela maioria dos setores sociais que compõem o poder local.

Por outro lado, a presença militar nessas áreas é revestida de um caráter estratégico especial, reconhecidamente humanitário, que atribui aos militares que atuam na área uma espécie de "heroísmo moderno", já que o cenário atual de acordos e cooperações regionais na América do Sul, e em outras escalas, não permite a construção da figura clássica do herói de combate. Por isso acreditamos que a "causa indígena" e ambiental, como se verá adiante, se tornaram grandes aliadas para o status quo militar.

Considerando todos os aspectos e sutilezas dessa geopolítica recente, vemos que os estados têm buscado garantir uma maior participação nos recursos do Calha Norte, visto atualmente como capaz de conciliar interesses antagônicos e como alternativa viável, dentro do cenário que se apresenta para a Amazônia.

O caso do Acre é bastante significativo por ter implantado uma política inovadora, desde o início da gestão do governador Gilberto Viana, em 1998, sobretudo no que se refere à ênfase atribuída às questões ambientais, como atesta o trecho: ${ }^{49}$

O governador Jorge Viana disse que o programa Calha Norte é um programa ágil, que tem eficiência em sua aplicação. (...) Conseguimos pôr esses $R \$ 42$ milhões em obras de infra-estrutura na capital e no interior, feitas pelo Estado e pelos municípios. (...) Segundo ele, a união entre o governo, inclusive com o ministério da Defesa e seus militares, envolvendo o governo do Estado, a bancada federal $e$ as prefeituras, vem dando muito certo. "É assim que o presidente Lula quer que trabalhemos. Ele quer a Amazônia se desenvolvendo de forma sustentável e com muitas melhorias nas áreas de fronteira. Eu acho que o Calha Norte executa o sonho do presidente Lula e de todos nós", disse. ${ }^{50}$

Como se percebe, estamos diante de novos signos e posturas políticas definidas, sobretudo, pela gestão compartilhada entre diferentes atores, independentemente da filiação ideológica que assumem. Diante da emergência de soluções para os problemas, a

\footnotetext{
$48 \quad$ Frase e conceitos bastante presente em várias publicações do meio militar.

49 O Acre chama atenção pela presença de duas personalidades de destaque internacional - vinculados, e parte das lutas sociais dos seringueiros nesse Estado: a atual ministra do Meio Ambiente Marina Silva, cujo mandato iniciou-se em 2003, e o líder seringueiro Chico Mendes - assassinado em 1988, apresentado também como símbolo e mártir do sócio-ambientalismo da atualidade. $24 / 02 / 2005$

Do artigo: "Calha Norte investe R\$ 42 milhões no Acre”. Jornal Página 20, Rio Branco/AC.
} 
tônica é colocada na gestão participativa, na tentativa de se agregar os interesses convergentes.

Programas como Calha Norte, SIVAM e SIPAM têm hoje o desafio de aglutinar as diferentes situações encontradas e de fazer com que possam convergir para uma política comum. Cabe aos programas a função de fazer os delineamentos estratégicos gerais, sua identificação e caracterização, com prioridades para ações de desenvolvimento. Entretanto, não lhes compete exclusivamente o detalhamento de projetos, que é feito por outros instrumentos de planejamento, de caráter operacional, segundo a agenda local.

Portanto, parece que na visão dos políticos de qualquer tendência, o que interessa é a aplicabilidade e a eficiência desses programas. No caso dos programas Sivam/Sipam é bem mais complicado dimensionar a eficiência, por toda a parafernália que os envolvem e pela exigência de conhecimento específico em tecnologias avançadas em sistemas e subsistemas integrados de sensoriamento remoto, coleta de dados ambientais e sociais de toda ordem e de outras tecnologias ligadas a aviação, à comunicação, à vigilância e ao monitoramento por satélites e outros meios.

Assim, o PCN parece estar recebendo mais adesões em razão de que suas ações são mais nítidas na paisagem local, já que a construção de infra-estrutura é sempre valorizada por se tratar de uma marca concreta, visível no espaço e bem diferente de programas mais sofisticados como o SIVAM/SIPAM, que só recentemente vêm conseguindo mostrar resultados mais tangíveis, como se verá adiante. 


\section{II.5 As tecnologias do SIVAM/SIPAM conectando os espaços}

O SIVAM foi concebido em setembro de 1990, como projeto especial no âmbito da Secretaria de Assuntos Estratégicos (SAE) da presidência da República, em parceria com os ministérios da Justiça e da Aeronáutica. Visava a estabelecer um parâmetro de gestão de políticas compartilhadas na área de defesa para a Amazônia e foi implementado como resposta brasileira aos grandes impactos ambientais, objeto da crítica interna, e sobretudo, externa. Ao tempo em que se criava o PPG- $7^{51}$, com gestão compartilhada com o BIRD e doadores do G-7, o SIVAM parece ter sido a alternativa para uma estratégia de caráter eminentemente nacional ${ }^{52}$.

Em decorrência das reestruturações ocorridas em vários setores do governo no início da década de 90, foi extinto o Ministério dos Projetos Especiais, que sediava o SIVAM, deixando-o sem paternidade por um bom tempo. "Jogado de um canto para outro, hibernou na Presidência da República até caiu no Ministério da Defesa, onde permaneceu um tempo sem lugar fixo" No atual governo, está de volta ao organograma desse Ministério. $^{53}$

A "implantação completa" ${ }^{54}$ do SIVAM/SIPAM ${ }^{55}$ só foi efetuada no ano de 2006 , o que torna difícil fazer uma análise mais abrangente de seus resultados. Por isso mesmo, ainda estamos longe de poder avaliar com eficácia a idéia de um sistema complexo e que opera em tempo real, com informações que possam chegar e interessar aos amazônidas, entendidos como os beneficiários finais do caríssimo e sofisticado programa.

$51 \quad$ Programa Piloto de Proteção às Florestas Tropicais do Brasil, iniciado em 1991, tem foco central na preservação da Amazônia, embora no desenrolar do processo de sua implementação, tenha conseguido inserir em sua agenda outras questões de ordem social, aceitas no escopo do programa. A literatura a respeito desse programa é bastante ampla, inclusive por ter sido monitorado e avaliado periodicamente por alguns grupos como o IAG (International Advisory Group), a OCIP Amigos da Terra e por todos os organismos nacionais e internacionais participantes. Vide a respeito a tese de doutorado de MELLO, N.A., 2002b).

52 Estamos nos referindo à gestão política do programa, uma vez que a participação de tecnologias produzidas fora do Brasil é um componente central do programa, além do próprio financiamento, concedido pelo banco oficial americano, o "Eximbank.

53 Artigo: Desperdício amazônico - Gilberto Paim em 10/08/2003 Jornal do Brasil

54 Embora todas as etapas de implantação do projeto já tenham sido cumpridas, resta a utilização efetiva do sistema por parte dos usuários finais. Nos estados amazônicos, foram implantados os CEUSCentros de Usuários, em instituições como as Secretarias de Meio Ambiente, e foram distribuídos equipamentos para vários órgãos como Postos da Funai, Funasa, Receita Federal, PEFs etc. Há, no entanto uma grande dificuldade em manter o sistema em funcionamento pela ausência de mão de obra qualificada em número suficiente para operá-lo; pela dificuldade em manutenção dos equipamentos, dentre outros fatores que travam o funcionamento do sistema.

55 Utilizaremos o "singular" para nos referirmos aos dois programas por uma questão de recurso estilístico, sempre que nos referirmos à sua concepção atual, de complementaridade entre os dois. Mas, daremos destaque às diferenças, utilizando o plural, quando necessário. 
O Sistema de Vigilância e Proteção da Amazônia - SIVAM/SIPAM, tal como o PCN, parte de uma concepção de políticas integradas e tem o objetivo de constituir um sistema que funcionará em rede e do qual farão parte os três níveis da administração pública: federal, estadual e municipal. Como se percebe, há uma insistência quanto à necessidade de agregar vários setores: empresariais, científicos e sociedade civil, dentre outros.

O SIVAM/SIPAM estrutura-se a partir de uma rede de tecnologias altamente sofisticada para efetivação do papel de vigilância e proteção da Amazônia. Essa tarefa engendra, por um lado, a necessidade de se criar um forte aparato para produção e veiculação de informações e; por outro, promove a realização do monitoramento ambiental. Esta última é uma ação sem similiar no continente e quiçá no planeta.

Sendo a Amazônia o maior espaço dotado de florestas tropicais da atualidade, a produção e veiculação de conhecimento, bem como o controle e fiscalização para tão vasta área transformam esses programas numa experiência inédita. Se acaso conseguirem alcançar os objetivos básicos traçados, isso pode significar a realização geopolítica mais acabada de controle espacial, correspondendo a $61 \%$ do território nacional que podem ser monitorados de modo permanente por radares ${ }^{56}$.

Esses propósitos geopolíticos foram amadurecendo ao longo de, aproximadamente uma década, quando o País abandonou a via de grandes projetos impactantes ao meio ambiente, típicos da década de 1970, e assumiu um novo discurso no que se refere à Amazônia, agora baseado no conceito de sustentabilidade ambiental.

Esse novo momento da democracia brasileira, iniciado, em torno de 1990, é marcado pela tentativa de inserção do País no cenário global e teve como moeda de troca, no caso da Amazônia, a aceitação do governo brasileiro de efetivar projetos de parceria e cooperação bi e multinacionais, como é o caso do PPG-7.

Para a Amazônia, os novos programas também significaram, em termos econômicos, trocar as políticas da SUDAM, dos bancos e dos demais órgãos governamentais que concediam apoio e financiamento para projetos questionados do ponto de vista ambiental, por políticas que apostam em projetos ambientalmente

56 Os geopolíticos alemães do início do século XX - agrupados em torno da Zeitschrift für Geolopolik (Revista de Geopolítica), por exemplo, acreditavam que estavam diante da máxima realização de controle espacial quando iniciou-se a difusão do rádio e o uso das primeiras aeronaves, Que diriam hoje do Sivam/Sipam? A este respeito consultar: KOST, K. (1988); OSSENBRUGGE, G. (1983); BARBOSA, A (1996), dentre outros. 
sustentáveis. Essas duas últimas décadas foram de tentativas e os projetos desta natureza ainda são pontuais e com raras chances de servir de alicerce ao crescimento econômico, tal como é pretendido no discurso mais amplo para o território nacional. ${ }^{57}$

Neste sentido, o PCN rearranjado, e, o SIVAM, posteriormente agregrado à concepção do SIPAM, representam uma forma de manutenção de um projeto regional de canalização de recursos, ao mesmo tempo em que assegura o controle político, pelos dados que pode gerar e difundir sobre a região. Essas foram as saídas encontradas para responder ao "vetor tecno-ecológico", definido para a região. ${ }^{58}$

Em várias análises sobre a geopolítica na Amazônia, BECKER aponta "a intencionalidade do projeto geopolítico" destacando que nesse espaço a lógica não é necessariamente a econômica. Para a autora, "é sobretudo na Amazônia que o conjunto de intervenções estatais e os componentes da malha técnico-política se tornam mais patentes". Aí, o Estado pode operar com toda intensidade para eliminar o "vácuo de poder", tendo como instrumento mais eficaz a política de segurança e defesa. (BECKER, 1988:118)

Não apenas o caráter geopolítico, como também muitos outros aspectos, foram apontados pelos críticos do SIVAM quando do início de sua primeira versão, em 1995. Nessa ocasião, o programa tinha como foco central a questão da vigilância. Era, portanto, marcado por um significado mais punitivo, na medida em que a idéia de vigilância pressupõe fiscalização e, consequentemente, medidas para coibir ilícitos. $\mathrm{Na}$ visão de alguns críticos isso seria mais emergente na Amazônia que em outras áreas do território. Os fragmentos abaixo, retirados do artigo de LOURENÇÃO, sintetizam estas e outras polêmicas criadas com o surgimento do SIVAM.

A concepção e a implantação do Sivam foram cercadas de grande polêmica no âmbito parlamentar e científico brasileiro, com repercussões na mídia (grifos da autora). (...) Queda do ministro da Aeronáutica - Mauro Gandra , afastamento do

57 Consultar os vários projetos ambientais implantados após a década de 90, sobretudo, através dos documentos existentes no MMA. No âmbito do PPG-7, por exemplo, uma série de iniciativas serviu para alavancar mudanças institucionais, no que concerne à gestão de projetos, por parte de diferentes atores nos três níveis da gestão ambiental: União, Estados e Municípios, colocando-os em compasso com a "modernidade administrativa", presente, de algum modo, nos países que os financiaram. Além deste "pano de fundo", denominado na estrutura do PPG-7, por Fortalecimento Institucional, outros projetos de maior visibilidade, como os Projetos Demonstrativos, Tipo "A" - e o atual PPTAL (concebidos inicialmente como "Demarcação de Terras Indígenas"), compõem um leque imenso de iniciativas pontuais, do "vetor tecno-ecológico".

58 A este respeito consultar artigos e demais publicações da professora B.BECKER, alguns deles citados na bibliografia desta tese. Em relação ao "vetor-tecnoecológico", consultar o artigo: "Novos rumos da política regional" (1997). 
embaixador Júlio César Gomes dos Santos de sua função do cerimonial da Presidência da República. Suspeitas de espionagens e falsificações. Questão custo-benefício. Diferentes percepções de ameaças endógenas e exógenas. (...) (CASTRO, 2006:119 e 122)

Apesar das críticas, o SIVAM foi-se estruturando, até chegar a uma versão que inclui a gestão partilhada e proporciona maior intersecção com a sociedade civil. No formato atual, complementado pelo SIPAM - Sistema de Proteção da Amazônia (2002), o programa adquiriu outro escopo, com ênfase na questão da "proteção", e não apenas da vigilância.

Muitos órgãos acabaram se adequando para o SIPAM. A PF adquiriu aparelhos e sistemas de comunicação, e a própria $F A B$, na esteira do Sivam, comprou da Embraer os aviõe ALX (aeronaves leves de ataque), designados A-29, desenvolveram programas de reorganização e reaparelhamento para conseguirem aproveitar melhor o Sivam. (CASTRO, 2006:137)

O programa SIVAM movimenta uma cifra de bilhões de dólares ${ }^{59}$ e possui centros regionais de vigilância ( $\mathrm{CRV})$ em três capitais estrategicamente eqüidistantes na Amazônia: Manaus, Belém e Porto Velho, conforme figura abaixo.

\section{FIGURA 6}

Sistema de Vigilância da Amazônia - SIVAM

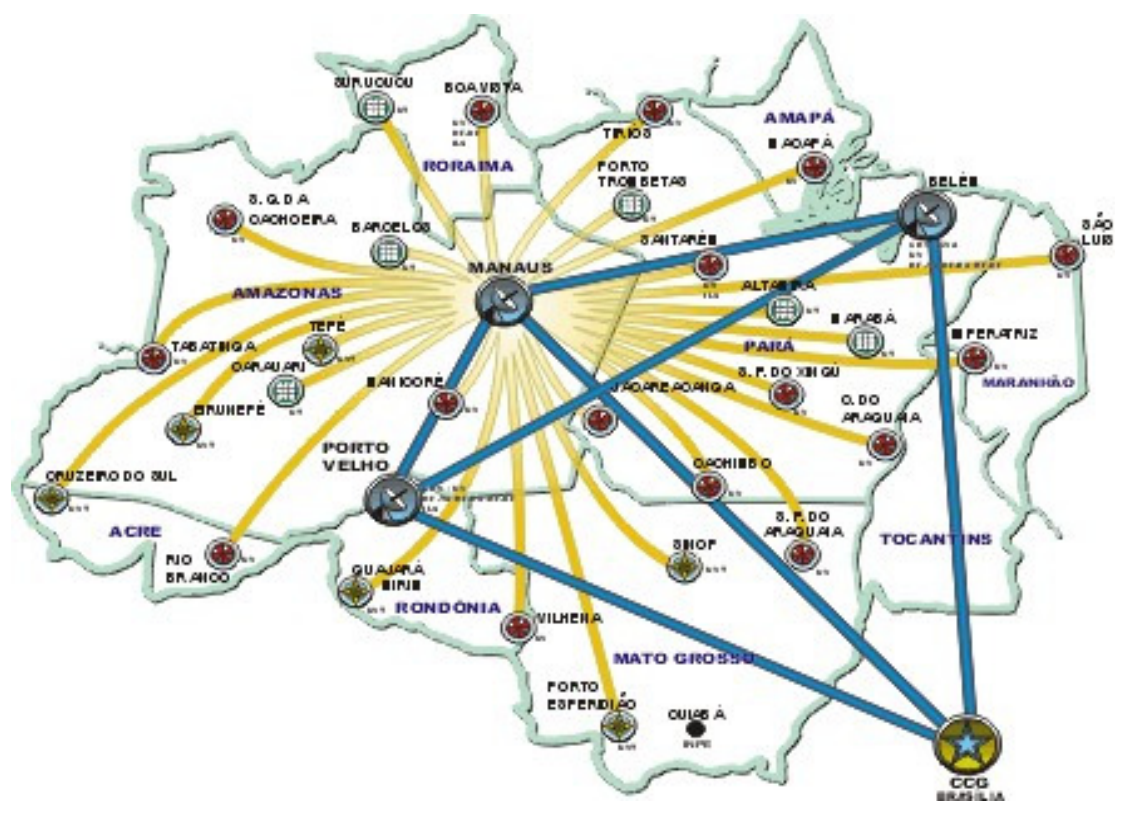

Fonte: CCSIVAM, Ministério da Defesa, 1999 
O programa SIVAM/SIPAM reúne informações de diversos órgãos e conta com sensores remotos espalhados por toda a Amazônia. Todo este aparato esta subordinado ao Centro de Coordenação Geral (CCG), que fica baseado em Brasília, como visto na figura anterior.

O projeto é coordenado por uma comissão interministerial diretamente ligada à Casa Civil da Presidência da República. O Ministério da Defesa, é, no entanto, o órgão responsável pela integração de todas as instituições envolvidas no SIVAM/SIPAM.

Pretende-se que a manutenção desse aparato seja realizada pela venda de produtos do próprio sistema. Este aspecto ainda não pode ser comprovado, sendo até difícil imaginar que em algum momento isto poderá ser realidade, pela soma vultosa envolvida.

Concebido para aglutinar informações de todos os órgãos que atuam na região e para compartilhá-las com diferentes usuários do sistema com acesso diferenciado, uma de suas metas é eliminar a duplicação de esforços e, portanto, fazer convergir atividades dispersas e desconhecidas e, assim, aprimorar instituições que operam, de algum modo, isoladamente.

Esta intenção do SIVAM/SIPAM foi criticada como contradição apriori do programa, encarado como duplicador de atividades já desenvolvidas por órgãos como o INPE, como se vê no artigo assinado pelo jornalista Gilberto Paim:

Dois organismos dentro do governo estão desenvolvendo à revelia um do outro sistemas similares de monitoramento em tempo real da Amazônia. O Inpe (Instituto Nacional de Pesquisas Espaciais), mantido pelo MCT (Ministério da Ciência e Tecnologia), alimenta desde maio o Deter (Sistema de Detecção de Desmatamento), um banco de dados virtual sobre modificações na cobertura florestal. Subordinado à Casa Civil, o Sipam (Sistema de Proteção da Amazônia), braço civil do Sistema de Vigilância da Amazônia, o Sivam, se uniu em abril à Universidade Federal de Goiás para criar o Siad (Sistema Integrado de Alerta de Desmatamentos). Além de detectar o desflorestamento, o programa faz um atlas de suas causas socioeconômicas. ${ }^{60}$

O sistema SIVAM/SIPAM, neste sentido, teve que refinar seus objetivos para se diferenciar dos demais programas, já pretendidos por órgãos que também operam na interface do sistema. No caso de detecção de desmatamento ou mesmo de qualquer outro evento que o sistema monitora, o papel do SIVAM/SIPAM é o de atuar diretamente 
para coibir o ilícito. Para isso, deve dispor de instrumentos que possibilitem o acompanhamento direto do fato no campo. ${ }^{61}$

Hoje, só no estado do Amazonas, o Sipam mantém ativos 172 terminais de usuários. Através deles, a comunidade pode solicitar ao Sipam em Manaus, pesquisas na internet, enviar documentos para serem entregues na capital como Declaração de Isento do Imposto de Renda, certidões, e também podem receber cópias de documentos e editais de concursos públicos.

Atualmente, o Sipam em Manaus mantém um cronograma semanal para enviar pelo Terminal de Usuário informes sobre programas sociais do governo federal como Bolsa Família, Bolsa Escola, Fome Zero e informações sobre o Programa de Erradicação do Trabalho Infantil (Peti). ${ }^{62}$

Em palestra, o General Alcedir afirmou que, em toda a Amazônia, estão espalhadas quase mil instalações do SIVAM, incluindo pequenas antenas, distribuídas nos pelotões de fronteira. Enfatiza ainda: "teremos informações de vários quilômetros para dentro de outros países". De fato, os equipamentos de comunicação instalados em áreas isoladas têm revolucionado o cotidiano dessas localidades. Até mesmo aldeias que não mantém praticamente nenhum contato com o "mundo civilizado" têm sido impactadas com as novas tecnologias, como atesta o trecho que segue.

Desde que entrou em funcionamento, em 2003, o Sistema de Proteção da Amazônia (Sipam), do qual faz parte o Sivam, deixou para trás os tempos em que a sigla era relacionada ao escândalo que derrubou um ministro, em 1995, e provocou a criação de uma CPI para investigar os contratos com a fornecedora norte-americana Rayethon. Hoje, está provada a eficiência do sistema. Só no ano passado, os equipamentos que monitoram cada centímetro do território amazônico em busca de ações de desmatamento, narcotráfico e movimentações na fronteira participaram de 42 operações integradas com órgãos como o lbama e a Polícia Federal. Este ano, o projeto vai receber mais $R \$ 65$ milhões em investimentos. $^{63}$

Em municípios fronteiriços e em aldeias isoladas, o SIVAM/SIPAM, com todo o aparato tecnológico de última geração, constituído por radares fixos e móveis, sensores térmicos, estações meteorológicas, satélites e outras tecnologias de defesa, ainda funcionam como obra de ficção. Durante nossa visita à sede do SIVAM/SIPAM, em Manaus, ficamos realmente impressionados com a grandiosidade dessa instituição, que

\footnotetext{
61 Durante visita realizado ao SIVAM/SIPAM, em Manaus, em novembro/2005, foi-nos mostrada uma caixa que continha vários instrumentos capazes de realizar o monitoramento local, processar e enviar dados, fazer uma comunicação mais direta e instantânea com áreas isoladas - uma espécie de "sivanzinho de bolso", adaptado para o trabalho in loco, no formato de uma mala disponibilizada ao técnico enviado a essas áreas.

62 Vide Artigo: Estrutura do Sipam vai auxiliar trabalho do poder judiciário na Amazônia - Website Radiobras 22/05/2005
}

63 Artigo: Infra-estrutura - É dura a vida de quem quer ir e vir na Amazônia - O Estado de São Paulo, 02/10/2005. 
fica afastada da cidade, num prédio altamente seguro, com portas que se abrem a partir de códigos de acesso restritos.

Lá de dentro, através de sofisticados computadores, pode-se ver, animada, como numa tela de cinema, a "realidade seletiva" da floresta: pode-se ver a dinâmica troposférica bem presente. É uma visão de cima! Pode-se identificar garimpos ilegais, focos de queimada e aferir outras possibilidades de ilícitos, através de cruzamento de dados e do conhecimento técnico das possíveis situações que se repetem na Amazônia. Não obstante, apesar de todo o aparato tecnológico, ainda não foi concretizada a necessária complementaridade com outros órgãos que atuam na fiscalização, no controle e na busca de solução dos problemas que aparecem na tela.

E, este é o nó da questão! O SIVAM/SIPAM pretende não apenas ser "os olhos da Amazônia", mas a mente, os braços e as mãos que operacionalizam as ações necessárias. Este é o seu desafio. Mas, para ser o "coração" da Amazônia, já lançou algumas estratégias de penetração no tecido social. Através da Revista "Sivanzinho64", vem tentando cativar o público infanto-juvenil das escolas públicas de vários municípios amazônicos, que já receberam esse impresso. O protagonista da história é um indiozinho bem culto e bem "antenado" aos problemas sócio-ambientais da Amazônia. ${ }^{65}$

Lembramos, porém, que a iniciativa de romper o isolamento de comunidade isoladas na Amazônia já vinha sendo realizada antes, através de algumas iniciativas pontuais, como a da OCIP "Amigos da Terra", que instalou mais de duzentas estações de radiofonia, através de seu projeto "Rádio Amazônia", que existe desde 1991. Essas estações servem como canais de comunicação entre os grupos para informações relativas a queimadas - para evitar o alastramento do fogo - como também a outras finalidades emergenciais e agremiativas desses grupos.

Programas desta natureza, com custos infinitamente menores, têm demonstrado o grande potencial da comunicação para solução de problemas locais imediatos. Eles incorporam, inexoralvelmente, "espaços letárgicos"66 à racionalidade moderna. Uma

\footnotetext{
64 Pode-se ter acesso a esta revista através do Website do SIVAM/SIPAM.

65 Mais uma vez, destacamos o paralelo com os escritos geopolíticos, da revista alemã ZfG (Vide BARBOSA,A.1996), onde vários artigos são dedicados ao ensino e aos instrumentos de "enculcação" dos ideais alemães das primeiras décadas do século XX. Embora, o foco nacionalista seja diferente aqui e agora, nossos estrategistas perceberam que sem um bom marketing político dos programas em questão, é muito provável que fiquem restritos a um grupo seleto de especialistas.

66 SILVEIRA, M.L.(1999:414), analisando o caso da Argentina, usa os conceitos "Letargia" e "Luminosidade", para contrapor sistemas técnicos em descompasso.
} 
experiência que bem retrata as formas e o poder da "comunicação na floresta" é analisada na tese de Mônica BARRETO ${ }^{67}$. Abaixo destacamos, uma de suas conclusões quanto à importância do rádio para a transformação e estruturação do cotidiano em Gurupá/PA:

To conclude, the case of Gurupá shows that by facilitating the exchange of messages concerning knowledge, social, cultural and political capital assets the radio contributes to increased levels of conscientização. It is important to remember that the conscientização process in Gurupá was started some 20 years ago when the only means of communication available was the 'canoe', giving rise to a strong local social movement. However, with the arrival of both radios (community radio and two-way radio network) the social movement has clearly grown in terms of strengthening not only the inter-community (micromicro) linkages, but the vertical (micro-macro) links between the social movement and external organisations, putting Gurupá on the map of socio-environmental policy making processes for Amazonia. BARRETO,M.M. (2006:254)

O atual SIPAM, que quer ser reconhecido pela atuação civil, tenta, assim incorporar alguns elementos presentes em projetos de natureza comunitária - como os citados anteriormente - esforçando-se para transformar grupos isolados em potenciais aliados, e assim, poder atuar em prol dessas comunidades. Atualmente, o indígena, o "caboclo" de áreas ribeirinhas e outros grupos que não dispõem de tecnologias de comunicação, são parceiros fundamentais, em campo, para acionar o sofisticado sistema ${ }^{68}$. O Programa, pretende, portanto, ser um importante canal de atendimento à multiplicidade e heterogeneidade dos povos amazônicos.

No âmbito do Plano diretor e da agenda 21, o SIPAM tem buscado a articulação das várias instituições que o elaboram nas diferentes municipalidades amazônicas, onde o processo não é conduzido por outra instituição. O SIPAM fornece informações espaciais a partir de bases cartográficas e temáticas georreferenciadas que produz, bem como, daquelas que são disponibilizadas pelo IBGE. Neste sentido, realiza uma das necessidades tantas vezes discutidas, durante a elaboração dos Zoneamento Ecológico Econômico, ZEEs, nos Estados amazônicos.

Referimo-nos às longas jornadas, desde o início dos anos 1990, no intuito de aglutinar as várias instituições para participação no processo de elaboração do ZEE. Em

\footnotetext{
67 BARRETO, Mônica M. (2006) - Waves in the Forest. (2006)

68 Também durante nossa visita à sede do SIPAM, em novembro/2005, foram-nos relatadas algumas experiências de vigilância em áreas de floresta, a partir da comunicação feita, através dos equipamentos instalados em localidades isoladas.
} 
meados desta década, este processo passou a ser conduzido pelo PPG-7, a partir de um dos seus componentes: o Subprograma Política de Recursos Naturais. ${ }^{69}$

A elaboração de um documento propositivo, que pode ser entendido como a Agenda 21, base para o Plano Diretor do município, era um dos produtos de maior complexidade. Buscou-se implementá-lo através do ZEE, desde a elaboração de uma metodologia que foi finalizada com discussão em todos os Estados amazônicos, em 1996.

Embora nesse momento, ainda se discutisse a elaboração de cartas temáticas em escalas muito pequenas (1:250.000, por exemplo), para muitas localidades da Amazônia, a metodologia proposta ${ }^{70}$ já incorporava a idéia do planejamento participativo, presente na "Agenda 21", como etapa final de um processo que chegaria a escalas adequadas para o planejamento, com participação efetiva da comunidade na definição de políticas territoriais.

Os ZEEs, que à época, também receberam uma série de críticas, inclusive pela "soma considerável" de recursos físicos e humanos que envolvia - e isto não devia chegar a casa de US\$ 2 ou 3 milhões, nos casos em que se gastou mais ${ }^{71}$ - são hoje subprodutos singelos para complementar o SIPAM/SIVAM, dotado de infra-estrutura para inseri-los na escala regional.

Podemos, assim, entender que o SIPAM, através da articulação e disponibilização de dados, pretende cumprir uma etapa que parecia impossível durante a realização dos ZEEs, pois não estava claro quais seriam os mecanismos necessários para acessar a dados técnicos e específicos das diferentes áreas do conhecimento, que compõe os ZEEs. Os Centros de Usuários, nesse sentido, foram pensados para desempenhar esta função:

As informações geradas pelo Sivam estão disponíveis a qualquer cidadão que se interessar, através do Centros Estaduais de Usuário (CEUs) que funcionam em locais determinados por cada estado, podendo ser na secretaria de meio

\footnotetext{
69 Jornadas das quais participamos enquanto membros do SPRN, para o estabelecimento dos marcos centrais que nortearam em muitos aspectos a elaboração e implementação do ZEEs dos estados amazônicos. Vide: MELLO, N. 2002b.

70 Vide: LAGET/UFRJ: Detalhamento da Metodologia para Execução do ZEE na Amazônia, 1996. A respeito dos aspectos técnicos do ZEE há um ampla bibliografia. Consultar as publicações da SAE/PR, de 1990-95. Após esta época, vários documentos foram produzidos pelo MMA, que ficou encarregado de sua coordenação. Além disto apresentamos na bibliografia desta tese uma série de outras referências críticas.

71 Referimo-nos ao ZEE, elaborado no âmbito do PPG-7. Vide documentos em arquivo do MMA e BIRD.
} 
ambiente ou na secretaria de ciência e tecnologia, por exemplo. Os nove estados da Amazônia já tem o CEU em funcionamento. ${ }^{72}$

O funcionamento, destes centros, porém, ainda podem ser considerados experimentais em várias localidades, como é o caso de Boa Vista, pois desde sua criação, houve dificuldades com a manutenção dos equipamentos, disponibilidade de especialista para operar o sistema, dentre outros aspectos que travam seu 0 funcionamento. Em todo caso, aposta-se que o SIPAM seja uma ferramenta básica para alavancar a pesquisa em muitos setores e, inclusive, para articular políticas regionais em parceria com países vizinhos, que teriam à disposição dados para o monitoramento ambiental de áreas cobertas pelo SIVAM.

O SIVAM/SIPAM pode desempenhar papel de destaque na nova estratégia de integração da Amazônia ao cenário sul-americano, fornecendo subsídios técnicos e logísticos para uma gestão compartilhada nas áreas de meio ambiente, segurança e defesa das regiões fronteiriças. Nesse sentido, tem havido, nos últimos anos, uma série de reuniões, de acordos e exercícios militares conjuntos, contando com a presença de ministros da defesa e de outras autoridades responsáveis pelo tema.

Para Rosalia Arteaga, a troca de tecnologia e informações será essencial para efetivar a missão institucional comum da $\mathrm{OTCA}^{73}$ e do Sipam: a gestão integrada dos recursos naturais da Amazônia. Como a natureza não respeita fronteiras políticas - a água é um exemplo clássico disso - é preciso que os países compartilhem dados e planejem conjuntamente sua política ambiental para a região. Isso auxiliará na fiscalização da floresta, principalmente de ilícitos, como as queimadas, o tráfico de biodiversidade, a retirada ilegal de madeiras preciosas" (...). ${ }^{74}$

Como resultado do monitoramento das fronteiras, no âmbito do SIVAM/SIPAM, já é nítida, por exemplo, a redução da invasão do espaço aéreo da Amazônia por aeronaves clandestinas ou suspeitas. Para isso tem contribuído a regulamentação da Lei do Abate, do final de 2004. Entretanto, o controle terrestre, precisou ser redobrado, uma vez que o transporte ilícito tem utilizado outros meios, que não o aéreo.

\footnotetext{
72 Vide artigo: Proteção da Amazônia ainda não tem núcleo de telecomunicações - ComCiencia, Campinas - SP, 08/08/2003. Link: http://www.comciencia.br.

73 A Organização para o Tratado de Cooperação Amazônia/OTCA é composta por oito países: Brasil, Bolívia, Colômbia, Equador, Guiana, Peru, Suriname e Venezuela. Rosalía Arteaga Serrano é a secretáriageral da OTCA. $06 / 06 / 2006$

Vide artigo: Sipam será base para monitoramento internacional da Amazônia - Website Radiobrás
} 
Ainda há muito a se percorrer para que os problemas de ilícitos na fronteira Amazônia sejam resolvidos com mais eficácia, mas já se percebe que os exercícios militares conjuntos, a troca de dados e informações, a partir do SIVAM/SIPAM de e outros acordos que aprimoraram a relação entre os agentes militares na região, são elementos importantes no marco das cooperações com os países fronteiriços.

É reforçada também a percepção de que as parceiras internacionais podem ser estendidas a vários setores, inclusive já se busca a integração das indústrias de defesa. $A$ intenção é que os países da América do Sul atuem em conjunto, "tanto como compradores e importadores quanto como produtores e exportadores." A idéia é que os países amazônicos alcancem "economia de escala" e coerência nas negociações, e, obviamente, reforcem seus elos de integração e confiança mútua. (Relatório MD, 2003)

Há de se considerar, em relação a este aspecto, que o território, longe de desaparecer, insere-se nas "novas solidariedades verticais" regulados em nível global. Assim, alianças econômicas no setor da defesa podem se tornar parte da estratégia política que cada um desenvolve.

Da mesma forma, os grandes programas que vêm sendo analisados nessa seção podem ser entendidos como verticalidades no território, onde a escala de comando situase a milhas de distância. Esse controle não ocorre apenas nos centros de controle do SIVAM/SIPAM, mas dentro de uma lógica global que captura todos os espaços e que demandou décadas para instalar-se definitivamente como conceito único, politicamente correto, viável, e permanente para a Amazônia: trata-se do conceito de desenvolvimento sustentável, que é uma contradição de termos, mas que é indiscutivelmente aceito em todas as políticas para a região.

O novo modelo só terá sua eficácia comprovada quando os dados puderem ser apresentados em tempo real e simultaneamente utilizados por agentes capazes de resolver localmente os problemas identificados nas imagens de radares ou comunicados por indivíduos da comunidade ${ }^{76}$. Ou seja, a comprovação da eficiência somente poderá ser feita no dia em que os centros de pesquisa, e pesquisadores individuais e/ou outros interessados puderem fazer uso do sistema rotineiramente. Deste modo, os militares

\footnotetext{
75 Em relação aos modos de regulação no período técnico-científico informacional, vide SILVEIRA (1999:241-279)

76 Hoje a tecnologia do sistema "chega antes que as pessoas", fazendo-se um paralelo com a época em que a estrada chegava antes.
} 
deixam o papel de protagonista para atuar como meros usuários do sistema, uma vez que os problemas amazônicos são extremamente mais complexos que os de segurança e defesa.

De acordo com tal paradigma, não convém que a preservação da soberania brasileira na Amazônia seja garantida apenas através de empreendimentos estratégico-militares na área, mas pela implantação de um conjunto de políticas públicas que faça convergir crescimento econômico, desenvolvimento social, preservação ambiental e defesa.(CASTRO, 2006:140)

Há ainda muito a dizer em relação à atual geopolítica que conecta o espaço cotidiano de pequenas localidades às grandes redes de tecnologia e informação. Não obstante, a análise de programas tão grandiosos como os destacados nessa seção, não se esgota nesses poucos parágrafos. Há muitos outros elementos que poderiam ser debatidos neste capítulo, mas, devido às limitações desta pesquisa, procuramos apenas mostrar a dimensão desses programas e seu significado enquanto "verticalidade" que se instala na geografia local, desde as aldeias às metrópoles regionais da Amazônia.

Estabelecendo um paralelo com as antigas idéias dos geopolíticos de controle e de dominação do espaço, não fosse o discurso atualizado em favor do desenvolvimento sustentável e da gestão democrática presentes nos Programas Calha Norte, Sivam/Sipam ${ }^{77}$, poder-se-ia dizer que se assemelham à realização mais eficaz de um programa geopolítico para a ação em todos os setores da vida social, política e cultural e de segurança da população fronteiriça. ${ }^{78}$

A partir do momento em que a Amazônia se configura como uma espécie de "Lebensraum"79 para o planeta, o discurso militar apropriou-se desse significado para reforçar seu papel no controle e segurança da região e, consequentemente, seu protagonismo em setores afins.

\footnotetext{
77 E aqui, também poderia ser incluído o PPG-7, por ter participado, pioneiramente, na formação das concepções básicas de gestão ambiental, desenvolvidas como piloto, através dos vários sub-componentes deste Programa. Nós que participamos de sua elaboração e execução nos estados amazônicos, durante alguns anos, podemos perceber que o discurso presente (e a prática) mantém os elementos centrais, formulados desde início da década de 90.

${ }_{78}$ Dentre os autores que tratam do discurso geopolítico do início do século XIX, podemos citar: RÖSSLER, M. (1990); e SCHÖLLER, P. 1957 à 1989.

79 Conceito da geopolítica alemã do início do século XIX, usado para justificar a "necessidade" de ampliação do território alemão, para atender aos aspectos vitais de sua população. No contexto amazônico, compreendemos que sua biodiversidade tem sido colocada, por parte de alguns grupos, num patamar similar em relação às "necessidades vitais da humanidade".
} 
Deixando para segundo plano a idéia da criação de unidades militares enquanto foco da intensificação da presença humana, as antigas colônias militares que se transformam em vilas e cidades, os militares perceberam que ter a natureza como aliada reforça seu papel no novo cenário, agora dotado de outros signos. A existência de populações isoladas e de áreas de selva de difícil acesso reforça a importância de um setor que sempre esteve no comando de decisões importantes do País.

Feita essa discussão em torno dos grandes programas para a Amazônia, na próxima seção trataremos de interpretar o seu significado. 


\title{
Capítulo III
}

\section{UMA INTERPRETAÇÃO DO SIGNIFICADO DAS FORÇAS ARMADAS}

\section{III.1 A tradição militar no Brasil}

Raymundo $\mathrm{FAORO}^{80}$, em obra magistral publicada em meados da década de 1950 sobre a estrutura do poder no Brasil, mostra que o "militar" é figura central na estrutura de comando do País, desde os primórdios da colonização, embora, o uso do conceito: "militar", não seja idêntico à versão que hoje temos do mesmo. Para esse autor,

\begin{abstract}
A palavra "militar" remete quase naturalmente à idéia de um profissional com habilidades técnicas específicas e que, além disso, incorporou durante os anos de sua formação um conjunto de valores e atitudes pautados por uma forte disciplina. Daí a imagem, também bastante naturalizada, de um grupo social unificado por forte identidade corporativa. Esse tipo de militar é uma criação histórica recente, que surgiu gradativamente, no século XIX, à medida que os modernos Estados nacionais se consolidaram na Europa". (CASTRO, 2006:33)
\end{abstract}

Para compreender o percurso que originou a figura do militar brasileiro tal qual o conhecemos hoje e o seu papel na estrutura política do País, reportamo-nos nesse capítulo à tradição portuguesa, instituída no Brasil desde a época da colonização, haja vista que entendendo ser este o viés que explica o "ethos militar" a que nos referimos neste trabalho.

No período da colonização brasileira, devido à escassez de recursos da Coroa, a guarda armada existente ficava muitas vezes sob a tutela da nobreza, que empregava seus próprios recursos para organizá-la e mantê-la. Até o período das reformas pombalinas, o "Exército português" constituiu-se de unidades que eram verdadeiras forças particulares. A nobreza possuía total ingerência sobre o mesmo, cujas unidades podiam ser colocadas a serviço da Coroa ou contra ela, dependendo do sistema de alianças e dos interesses em jogo no momento.

80 Sociólogo gaúcho, cuja obra recebeu, em 1959, o prêmio "José Veríssimo”, da Academia Brasileira de Letras. 
Para FAORO, o caráter militar da conquista que se processou no Brasil, através do bandeirismo, está vinculado ao sistema que à época imperava em Portugal e se prolongou na América.

A conquista da África e da Ásia, foi empresa militar, sem que o reino organizasse exército permanente ou sequer regular. As companhias e as pequenas unidades se formavam e se desfaziam de acordo com as necessidades transitórias da ação armada. O soldo (o quartel quando pago de quatro em quatro meses), o mantimento e o ordenado asseguram as relações com o tesouro e daí com a Coroa, afirmando o caráter público da estrutura militar. (FAORO, R. 1975:159)

O sistema de Bandeiras imperava desde a Idade Média em Portugal e era composto de trinta e seis homens, com capitães recrutados entre os mais velhos e honrados fidalgos, que escolhiam os sargentos e oficiais. No seu conjunto, as bandeiras formavam uma Companhia, cujo caráter de dispersão territorial contribuía para que assumissem uma forte autonomia, mal tolerada pelo chefe e comandante, o próprio rei.

No Brasil colônia, introduziu-se um sistema que partia do recrutamento forçado de indígenas para a defesa e depois para a conquista do interior. À medida que o sistema de colonato se expandia no País, o recrutamento passou a contar com uma presença maior de colonos, mesmo porque, em princípio, toda a população masculina entre 20 e 60 anos e capaz de combater poderia ser posta a serviço dos mandatários. ${ }^{81}$

Não era difícil convencer o colono a integrar-se às tropas armadas, pois os títulos militares, também oferecidos como conseqüência da atuação junto às tropas bandeirantes, correspondiam a uma marca de nobreza, sobretudo em São Paulo, "onde o poder não provinha do engenho de açúcar nem da riqueza do latifúndio, mas da força militar". No Império, a patente foi inclusive equiparada a um título de bacharel. Na colônia, mesmo o bacharel de Coimbra só se destacava com o título militar, como observa FAORO:

A origem do poder está na gente armada ou na capacidade de organizar uma companhia ou bandeira. Conquistadores e bandeirantes formam os caudilhos

\footnotetext{
81 SELVAGEM,C., 1991, mostra que a tradição de recrutamento em Portugal - vigente até meados do século XVI - remonta ao período medieval. Segundo essa tradição, "todos os fidalgos, cavaleiros e escudeiros, criados ou não da Casa Real (já que o rei não detinha monopólio sobre a distribuição de títulos, recursos, cargos e funções), deviam dispor sempre de cavalos e armas prontos para a guerra. Os demais senhores de terras, de acordo com o montante de seus rendimentos e posses, eram obrigados a possuir um número variável de cavalos, lanças, arcabuzes e mosquetes para servirem ao rei. Já os não proprietários, homens de ofício mecânico ou trabalhadores rurais, eram obrigados a ter lança ou dardo" (Op. Cit. CASTRO, 2006:36).
} 
coloniais - que, por excesso de linguagem, se equiparam à aristocracia, às origens da nobreza que o século XIX consolidaria. "Era então a nobreza paulistana, antes de tudo, uma nobreza guerreira - e não de riqueza, como ocorre posteriormente.

Inscreviam-se nos 'livros de S.Majestade', exibindo os seus grandes feitos no sertão, as suas mais notáveis gestas de bandeirantes: um maior número de índios acaudilhados, ou uma cópia maior de 'peças' apresadas, ou de malocas devastadas, ou de castelhanos desbaratados. O fato de serem pobres ou ricos pouco importava para isto, (já que a patente "embraquecia e nobilitava" quem a obtivesse - grifos da autora). (FAORO, 1975.163).

O caráter oficial dessas bandeiras, que excepcionalmente constituíam grupos não autorizados de aventureiros, torna-se explícito quando se considera que as patentes eram assinadas pelo próprio governador, sendo ele mesmo o sucessor no comando em caso de ausência do comandante.

Ademais, em situações de combate, todos os moradores tinham a obrigação de servir militarmente, conforme o regime implantado em Portugal, desde o século XVI. É com base nesse sistema português que se implanta na colônia brasileira, desde o primeiro Governo Geral, um plano de defesa e combate que começava com a construção de uma fortaleza na sede do governo, ainda de forma precária e longe de representar uma efetiva barreira contra inimigos externos, segundo a concepção dominante nessa época. FAORO, assim os descreve:

Havia, na sede do governo, uma fortaleza, que começaria de um valo, madeira ou taipal. De outro lado, reforçando a militarização dos moradores um duplo sistema proveria a defesa: a) os engenhos de açúcar teriam cada um em sua terra uma torre ou casa forte da feição e grandura, segundo o lugar em que estiverem, que bastarem para segurança do dito engenho e povoadores de seu limite"; b) para apoio das fortalezas e povoações, os capitães das capitanias, os senhores de engenho e os moradores deveriam estar munidos de artilharia e armas ofensivas e defensivas. (FAORO, 1975.165)

No caso das fronteiras brasileiras mais longínquas, como as da Amazônia, o sistema de "fortes" também foi adotado, ainda que com maiores dificuldades, em vista de seu alto custo de manutenção e até mesmo das dificuldades de pagamento do soldo para a guarda ali instalada. A região não contava com um grupo senhorial mais expressivo para dar apoio aos agrupamentos militares, de modo que não se pode dizer que tenham se estabelecido em caráter de permanência na maioria dessas localidades isoladas.

Acrescente-se também a grande dificuldade de manutenção das obras, precárias e rapidamente instaladas, até o final do século XVIII, na maioria das vezes, com uma 
estrutura de madeira, facilmente descartada em poucos anos, devido ao apodrecimento desse material, dada as condições pluviométricas locais.

Nos relatórios dos presidentes da Província do Amazonas, todas as referências a Tabatinga, como aos outros fortes, anunciam decadência, desmoronamento de trechos, apodrecimento do madeirame. (...) Em 1873, já com recursos mais amplos, foi então possível construir um grande quartel, residência para comando e oficiais, igreja. (REIS, 1942:167)

Alguns autores ${ }^{82}$ são da opinião de que, dada a fragilidade desses Fortes, não se pode dizer que tenham desempenhado papel relevante na defesa do território. Acreditamos, porém, que ao assim se posicionar esses autores têm em mente o conceito de contemporâneo que pressupõe uma presença mais ostensiva, mais equipada em número de homens, em armas, em tecnologias. No entanto, se nos ativermos ao cenário de ameaças existentes até o início do século XX, podemos constatar que as exigências no campo da defesa eram bem diferenciadas, o que permite considerar a importância simbólica e estratégica dos Fortes.

Em relação à política de defesa e segurança dos primórdios do Brasil, destacamos também o modelo de recrutamento senhorial, cuja estrutura organizativa de base territorial e política se estruturava conforme as "companhias de ordenanças" ou "ordenanças sebásticas", provenientes do sistema adotado em Portugal, a partir do século $\mathrm{XVI}$.

\begin{abstract}
A principal intenção da Coroa ao criar essas ordenanças ${ }^{83}$ era impor alguns limites à ampla liberdade senhorial, colocando-as na dependência direta das câmaras municipais. (...) Era a primeira tentativa de retirar da nobreza o monopólio do controle sobre a guerra". Segundo CASTRO, a primeira tentativa de formalizar a organização desses homens armados ocorreu no reinado de D.Sebastião (1557-78). (CASTRO, 2006:45)
\end{abstract}

Ao lado dessas forças, mantidas pela Coroa Portuguesa, foram se constituindo, milícias, como uma espécie de reserva não nobre das localidades, mas com a diferença de obedecerem ao soberano, e daí adviriam profundas conseqüências para o Brasil, em épocas posteriores. (FAORO, 1975:191)

\footnotetext{
82 "O viajante Paul Marcoy, (..) ao percorrer o Amazonas em 1847, (...) quando descreve as "obras militares", mostra seu total desencanto com o que via. Afirma que não havia na região "obra de fortitificação pela qual mereça semelhante nome'(...)" (CASTRO, 2006:60).

MELLO (2002a), trata com detalhes o aparecimento e o papel exercido pelas "ordenanças", em Portugal, desde o século XV, sendo elas, espécie de "agentes diretos do soberano", em várias áreas, funções e atribuições administrativas, inseridas em estamentos específicos, tais como os das "Ordenações Afonsinas (1446); “Ordenações Manoelinas” (1521); “Ordenações Filipinas” (1603).
} 
O aparecimento das milícias é um aspecto importante na compreensão da estrutura de poder local, posteriormente instituído no Brasil. Na sua origem, elas foram instituídas pelo Regimento do Governo Geral em 23/01/1677, a partir da distinção em relação às ordenanças (também chamadas de "gente miliciana"), que assumiam postos diferenciados. Mas, ambas não recebiam soldos, salvo os sargento-mores e ajudantes das ordenanças, que saem da tropa regular, arcando a câmara onde se situam com o soldo. (FAORO, ibidem)

Somente no século XVIII as milícias assumiram papel de destaque no cenário nacional, então constituídas como forças de apoio aos governos locais, ao lado e sob o comando da tropa regular. As ordenanças, embora existentes até 1831, perderão o relevo diante das milícias, responsáveis estas pela defesa contra o gentio, o bandeirismo, a epopéia pernambucana e as guerras do Rio Grande do Sul, associadas ou desvinculadas das tropas de linha.

A rivalidade entre a tropa de linha, portuguesa e leal à metrópole e as milícias, de formação e origem nacionais, se transmuta em dissídio aberto. A divisão Auxiliadora do Rio de Janeiro e o exército de Madeira na Bahia serão o mais eficaz obstáculo à emancipação, enquanto os milicianos de São Paulo e Minas sairão de sua terra para socorrer o príncipe, como haviam feito, algum tempo antes, nas lutas do sul contra o espanhol. Dessa labareda, sempre com funções separadas, sairá um novo exército e uma nova força auxiliar - o Exército e a Guarda Nacional, em cujo seio, em 1831, mergulharão as milícias e ordenanças.

Assim, ainda que vários autores que tratam da questão militar enfatizem a dessemelhança entre o que constitui as Forças Armadas da atualidade e as forças geridas por outros mecanismos, por outros códigos e valores e com funções distintas das que se exercem hoje ${ }^{84}$, decidimos iniciar a presente seção com essa discussão para situar melhor o fenômeno militar nas fronteiras de Roraima, nas suas continuidades e rupturas com esse sistema, como se verá mais adiante.

No caso de Roraima, o primeiro Forte só foi construído no final do século XVIII ${ }^{85}$, quando as "bandeiras" já tinham desbravado grande parte do interior brasileiro e as

\footnotetext{
84 Sérgio Buarque de Holanda Lembra inclusive, que "um traço marcante dos exércitos contemporâneos é sua vinculação direta com a idéia de nacionalidade. Todavia, no século XVII, o padrão era mais "cosmopolita”. (APUD CASTRO; 2006:45)

85 "Em 1775, uma expedição portuguesa, comandada pelo capitão-engenheiro alemão Filipe Sturm, a serviço de Portugal, iniciou na confluência dos rios Tacutu e Uraricoera, a contrução do Forte de São Joaquim, cujo fim era defender o sistema fluvial do rio Branco, e impedir a entrada dos invasores. A obra foi concluída em 1788" (FMATR, 1994:29)
} 
categorias "ordenanças e milícias" estavam em franca decadência. O que ocorreu na Amazônia foi um fenômeno diferenciado, que deve ser compreendido num contexto mais amplo e pretérito. É comum, em muitas obras, tratar essas "forças armadas" que defendiam e expandiam o território como idênticas espacial e temporalmente.

Existe uma ampla literatura a respeito do tema e que acaba ficando restrita a um publico muito pequeno de interessados ${ }^{86}$, que revela que essas forças armadas possuíam muitas diferenças e até divergências na sua atuação. De um lado temos as tropas regulares, mantidas pela Coroa, e que pelo próprio caráter de sua atuação adquiriam forte autonomia em relação aos desígnios do soberano. A essas, poderíamos chamar de "Exercito Regular", em relação às ordenanças e milícias, que foram constituídas no regimento da Coroa para manter fidelidade ao soberano, já que a Coroa não conseguia manter as forças regulares sob seu rígido controle.

Discutindo "experiências militares diversas", CASTRO traça um rápido perfil do sistema de defesa em vigor até 1640 e destaca a tradição medieval que regia sua institucionalização e o caráter excepcional de suas funções. O autor constata que de peões a oficiais, todos tinham seus ofícios, (...) e só se exercitavam no uso das armas a cada cinco semanas e que, para convocar 'essas esquadras' em situações de emergência, se recorria ao repique de um sino da cidade. (CASTRO:2006:40)

Prosseguindo em sua exposição, o mesmo autor mostra que em 1640,

a defesa do reino e de seus domínios foi dividida em três tipos de forças militares. O Exército formava a tropa de primeira linha, teoricamente integrado por 20 infantes e 4 mil ginetes, geralmente recrutados nas fileiras das ordenanças, pagos pela Coroa e organizados em terços de infantaria e companhias de cavalaria. A segunda força eram as tropas auxiliares, integradas por 25 terços das províncias e cinco de Lisboa. Por fim, havia as companhias de ordenanças, que mantinham sua estrutura antiga, vinculada às câmaras municipais.

O combate em guerras externas era, em princípio, tarefa do Exército de linha, como ficou estatuído no Regimento das fronteiras de agosto de 1645. Mas, quando necessário, as tropas auxiliares tinham a obrigação de prestar socorro às fronteiras, passando a receber, nesses casos, pagamento de soldos, uniformes e alimentação. As companhias de ordenanças tornavam-se, desse

86 De certo modo, as instituições civis mantiveram-se à margem dos debates sobre conceitos, instrumentos e processos militares. E, quando as instituições governamentais são formalmente responsáveis, falta-lhes não raro a familiaridade com a Defesa Nacional e com o mundo militar. (OLIVEIRA, E.R. 2005:54) 
modo, um verdadeiro depósito de recrutas para as tropas de linha e para os auxiliares. (CASTRO: 2006:40/41)

Frente a esse quadro, se pode afirmar que, desde a colonização, a estrutura acima apresentada foi reproduzida no Brasil. Essa importação gerou aqui uma gama bastante variada de "atuação militar", em geral mantida sob o comando dos governadores, que utilizavam essas forças para marcar seus poderes, muitas vezes, despóticos.

Em ampla pesquisa realizada sobre os meandros do poder na nascente sociedade brasileira, cuja análise se estende até o período da constituição da República, FAORO mostra como essa estrutura militar, "espinha dorsal da colônia, funcionava como elemento capaz de manter a ordem e disciplina, além de fornecer a base para aceitação dos tributos cobrados, e dos privilégios reais. Por isto mesmo seus integrantes constituíram-se numa casta privilegiada com poderes para se esquivar à justiça" - um sério problema posterior para a nascente sociedade nacional. Acrescenta o autor que "brancos e pardos conquistavam patentes e honras, insuflado, com a farda, o sentimento de obediência à autoridade." (FAORO, 1975:194 e 196)

Como resultado, ainda acrescenta que

Os milicianos moldaram a sociedade do interior, assegurando-Ihe, com seu vínculo ao rei, a disciplina, o obediência e o respeito à hierarquia. Além disso, revigoraram a tropa de linha, com a possível transferência para este corpo, como ocorreu com o Mar. José de Abreu, o primeiro Mena Barreto e outros. O Rio Grande do Sul não seria brasileiro sem as milícias; o frágil Regimento de Dragões impediria a pressão castelhana.

Sem as milícias o tumulto se instalaria nos sertões ermos, nas vilas e cidades. Verdade que, com elas, o mandonismo local ganhou corpo, limitado à precária vigilância superior dos dirigentes da capitania. (FAORO, 1975:194)

Para melhor compreensão desse sistema que adquiriu várias feições e exerceu tamanha influência na estrutura do poder local, deve-se destacar que em 1831, as guardas territoriais, formadas basicamente de milícias e de ordenanças, deram lugar à Guarda Nacional. Essa mudança ocorreu dentro de um novo contexto, então dominado pelas idéias liberais da Europa e dos Estados Unidos.

A continuidade do "espírito miliciano" no Brasil, no entanto, é notada por FAORO, para quem a Guarda Nacional Fundada para se contrapor ao Exército, da grandeza do qual desconfiavam os homens da Regência, tornou-se a mão da centralizadora presença monárquica, tal como na sua moldura colonial em perfeita continuidade. 
Mesmo depois, com a proclamação da República, o movimento federalista e liberal, aliado a uma resistência que começava a se esboçar nas cidades se opondo à monarquia - obsoleta para o novo cenário de liberdades e conquistas do século XIX apesar de fomentar a ideologia republicana, não conseguiu de imediato emplacar o tom republicano ao quinze de novembro.

Pode-se afirmar que muitos dos vícios acumulados durante séculos, no âmbito do "poderio armado", vão persistir e moldar a vida republicana em vários momentos, como atesta a passagem que segue:.

A interferência militar, situada entre o imperador sem herdeiros políticos e $o$ federalismo não amadurecido, desviou a direção dos acontecimentos, sufocou a revolução em marcha. A cor do governo é puramente militar. $O$ fato foi deles, deles só, porque a colaboração do elemento civil foi quase nula. (FAORO, 1979:537)

É assim que, mesmo após a Constituição, o militar garante sua permanência institucional definitiva. Uma das razões básicas para a continuidade desse poder era que apenas o Exército apresentava-se apto a garantir a integração de todas as unidades do país, dada a enorme extensão territorial, as diferenças políticas, culturais e econômicas e, sobretudo, à fragilidade do sistema republicano. Ao mesmo tempo, a instituição militar assegurava seu sentido institucional máximo: a defesa da nação coesa.

Deve-se entender, ademais, o peso econômico de estados como São Paulo e Minas Gerais, cuja hegemonia tendia a "aniquilar" o peso político exercido por outras unidades da federação. Neste sentido, uma aliança firmada pelos entes federados menos significativos economicamente com o Exército, tornou-se vital para a existência do sistema federativo. No quadro político de então, a influência dos partidos republicanos era sufocada pelas dissidências existentes entre os mesmos.

Bahia quer a força armada atuante, sob o controle do Supremo Tribunal Federal, em harmonia com o federalismo moderado de sua pregação política. (...) O Rio Grande do Sul terá no Exército um trunfo de reserva, cuidadosamente aliciado por Júlio de Castilhos e Pinheiro Machado, culminando com a ação de 1930. (...) O Estado do Rio de Janeiro, na hora de protesto da campanha da Reação Republicana, ronda os quartéis em busca de apoio e da voz da espada. (...) De São Paulo, Francisco Glicério manter-se-á fiel á convivência militar, não obstante a política dominante do seu Estado. (FAORO, 1979:542)

Neste cenário, o poder assumido pelo Exército é incomensurável, ocorrendo, inclusive uma "campanha civilista" entre os anos de 1909-10, com forte repercussão na 
época. $O$ "poder das armas" pode ser melhor compreendido quando se considera que de 15/11/1889 a maio de 1891, Deodoro e seus ministros nomearam dez governadores e, em 1893, cento e setenta e quatro oficiais que passaram a exercer funções políticas e administrativas. Numa atitude de comandante máximo, também dissolveu o Congresso, como se fora parte da hierarquia militar sob seu comando.

Em decorrência, a força militar mais centralizada na época de Deodoro adquire grande autonomia nos estados já no governo do Marechal Floriano Peixoto, seu sucessor Os Estados mais fortes economicamente passaram a liderar também por sua melhor condição de se armar, tornando o Exército prisioneiro das armadilhas estaduais.

Por outro lado,

a passagem do poder das mãos da federação do Brasil, para as mãos dos Estados não teria sido tão rápida se não tivesse havido a guerra de Canudos em que foi sacrificado o Exército nacional. No desprestígio que daquela guerra resultou para o Exército, o poder havia de ficar nas mãos de quem tivesse mais força. (FAORO, 1979:559)

Com um federalismo esgarçado pelas disputas político-partidárias do início do século XX, o Exército novamente assumiu seu posto privilegiado durante o governo Vargas (1930/45 e 1951/54), sobretudo após o golpe de 1937, que inaugurou o "Estado Novo".

Acompanhado de perto pelo alto comando do Exército e em compasso com as idéias nacionalistas e totalitárias de alguns países europeus, que perderam sua expressão com o fim do segundo conflito mundial, em 1945, Vargas reeditou uma série de medidas centralizadoras, como afirma o trecho abaixo. ${ }^{87}$

Após a guerra, o Estado-Maior do Exército trabalhou - de 1944 a 1969 - na reorganização, na reestruturação e no reaparelhamento da Força Terrestre. Foi instituída no Brasil, uma Missão Militar norte-americana, tendo sido firmado, em 1952, o Acordo de Assistência Militar com os EUA, que viria a perdurar até $1976 .^{88}$

87 Após os anos 1930, Hitler, na Alemanha; Mussolini, na Itália, e Franco na Espanha, são as principais referências de uma política centralizadora, autoritária, fascista, nazista, enfim, de extremo controle na vida social, econômica, política, cultural, ou em qualquer outro setor que se queira considerar. Sobre o "totalitarismo" vide: LEFORT, C. (1983) A Invenção Democrática; POLIKOV,L. (1974) O mito ariano, dentre outros.

88 Website do Exército. Texto: "Estrutura Organizacional". 
Nesse período, foi promulgada a Lei № 1.632, de 1952, que reestruturou o quadro de efetivos, passando o Exército a dispor de um aparato organizacional mais adequado para atender às demandas consideradas estratégicas, sobretudo em áreas fronteiriças. Assim, no ano de 1956, foram criados os Exércitos (I , II, III e IV), e o Comando Militar da Amazônia, com sede em Belém do Pará. (Ibidem)

Antes porém, em 1946,

estabeleceu-se, por decreto, a constituição das Forças Armadas em Exército, Marinha e Aeronáutica, com os seus elementos de atividade permanente, organizações de reserva e auxiliares quando convocados. Como chefe supremo dessas Forças, foi designado o presidente da República, auxiliado pelo Conselho de Segurança Nacional e pelo Estado-Maior, depois denominado Estado-Maior das Forças Armadas (EMFA)." (Ibidem)

Dentro deste novo contexto, as Forças Armadas moldaram sua personalidade a partir de uma cultura institucional com forte recorrência aos ideários do Positivismo vigente desde o século XIX. Na própria estrutura organizacional, os fundamentos do Positivismo aparecem com bastante nitidez, sobretudo no que diz respeito à ascensão na carreira. Segundo esta visão, a "evolução dos indivíduos" se dá via ciência - "meio eficaz para compensar os atrasos e as desigualdades existentes na sociedade." No âmbito militar isto equivale à ascensão pelo mérito ${ }^{89} \mathrm{e}$, em alguma medida, reforça a crença no meio interno (e em alguns setores externos), da eficiência das Forças Armadas no cumprimento do seu papel. Essa é a opinião de Souza, para quem

Desde a fundação das escolas militares no RJ, a educação, em detrimento da guerra, foi sobrevalorizada dentro das FA. A ascensão pelos estudos, por mérito e desempenho escolar ao contrário do pertencimento à aristocracia rural. Este foi um fator significativo na formação da visão cultural, social e política dos militares.."(SOUZA, 2002:132)

O projeto político dessa época, inspirado principalmente no modelo dos EUA, não rompeu com as visões de progresso no sentido comteano, existente no interior das Forças Armadas, e que marca a continuidade de ações protagonizadas pelos militares nas áreas de fronteira.

$89 \quad$ Embora este seja um componente importante da doutrina militar, temos que considerar que talvez a maioria dos oficiais, hoje, têm ascendência no próprio oficialato. Embora as escolas militares sejam abertas ao público interno e externo, através de concurso, certamente, as famílias de oficiais reúnem as melhores condições para a preparação dos filhos para a carreira militar e para o concurso em si. Mas, afirma-se categoricamente, nos meios militares, que "não se chega a general", senão pelo mérito, pois, para este e outros cargos de alta patente, existe uma série de "rituais" internos à coorporação, para avaliação do mérito. 
Esse período também não ficou caracterizado por ações significativas de cunho territorial na Amazônia. Apesar de em 1953 ter sido criada a Superintendência do Plano de Valorização Econômica da Amazônia, SPVEA, e o Fundo de Valorização Econômica da Amazônia, que correspondia a $3 \%$ das rendas tributárias da União, estados e municípios, os ideais desenvolvimentistas permaneceram concentrados na realização máxima da "Marcha para o Oeste" ${ }^{90}$, qual seja, na construção de Brasília.

A mudança da capital federal do Rio de Janeiro para Brasília ${ }^{91}$, marca mais audaciosa da geopolítica brasileira, recolocou em termos mais concretos as preocupações do setor militar no sentido de ocupar o "vazio demográfico" amazônico. Nesse novo cenário, havia mais possibilidade de isso se realizar, em vista da existência de uma malha rodoviária extensa e de grande vulto, iniciada com a Belém-Brasília.

Nos confins fronteiriços do Brasil, o "interregno democrático"92 não pôde ser sentido, sobretudo, nos recém criados Territórios Federais (1943), uma vez que os mesmos passaram à tutela direta do setor militar. Os territórios federais tornaram-se o espaço por excelência do centralismo republicano, com aparatos específicos de controle, a exemplo da Guarda Territorial, que se somaria à atuação dos Contingentes Especiais de Fronteira.

Os cargos políticos e tudo o mais que regia a vida dos territórios estava sob a intervenção militar. Seus interventores, sem a menor estabilidade no cargo, pouco ou nada contribuíram para a implantação de uma estrutura política e econômica que rompesse com a situação de dependência dos recursos da União. Isso é sentido notadamente em áreas não circunscritas pela malha rodoviária, como era o caso do Território do Rio Branco.

De acordo com 0 artigo $5^{\circ}$ do Decreto Territorial $n^{\circ} 1$ que versa sobre as atribuições da Guarda Territorial, nota-se que as ações de segurança, propriamente ditas, recebem menos ênfase que as ações de caráter social, como atesta o trecho que segue

90 A "Marcha para Oeste" pode ser compreendida como a recuperação do mito bandeirante ("bandeiras" paulistas que desbravaram "os sertões" a partir do século XVII), para o contexto da centralização do governo Vargas, baseado na busca de um ideal de brasilidade genuina - distante das influências europeizantes do litoral. No plano econômico, a "Marcha para Oeste" propagandeava o fortalecimento do setor agrário, através da estruturação da pequena propriedade agrícola, em áreas de "vazio demográfico"; dentre outros aspectos não concretizados.

91 A respeito dos propósitos geopolíticos da construção de Brasília, consultar VESENTINI, J.W. (1986) antecede ao Golpe Militar de 1964. 
os guardas serão encarregados dos serviços de vigilância, manutenção da ordem, construção e conservação de edifícios, estradas e caminhos, e, em geral, de todos os trabalhos de ordem pública, relacionados como saneamento, transporte, povoamento, colonização e incremento da produção do território".(SOUZA, 2002:148)

Nas próximas seções procuramos mostrar o que representou, para o atual Estado de Roraima, a ampliação das atribuições militares, e seu o desdobramento, durante o regime militar. Por ora, basta salientar que, com todo este percurso, o País ainda viveu, nos anos 1964-84, uma ditadura militar cujas seqüelas contribuíram, na visão de FAORO, para que as Forças Armadas

moldassem sua identidade, a partir de uma estrutura estamental, superior às contendas, fiel às tradições, tentando não se descaracterizar, e permanecer acima das querelas transitórias. O Exército, dirá agora, sem a lembrança dos dias de outubro e novembro de 1889, num recuo restritivo à carta republicana: $O$ Exército é a instituição essencialmente submissa à lei; é absolutamente subordinado à autoridade dos superiores". (FAORO, 1979:560)

De acordo com essa percepção, para cumprir seu papel, o Exército tem as seguintes atribuições, elencadas na Constituição de 1988:

Assegurar a defesa da Pátria: - contribuir para a dissuasão de ameaças aos interesses nacionais; e - realizar a campanha militar terrestre para derrotar o inimigo que agredir ou ameaçar a soberania, a integridade territorial, o patrimônio e os interesses vitais do Brasil.

Garantir os Poderes Constitucionais, a Lei e a Ordem: - manter-se em condições de ser empregado em qualquer ponto do território nacional, por determinação do Presidente da República, de forma emergencial e temporária, após esgotados os instrumentos destinados à preservação da ordem pública e da incolumidade das pessoas e do patrimônio, relacionados no art. 144 da Constituição.

Participar de operações internacionais, de acordo com os interesses do País.

Como ação subsidiária, participar do desenvolvimento nacional e da defesa civil, na forma da Lei ${ }^{93}$

Concluindo essa síntese da trajetória das forças militares no Brasil, destacaríamos que as Forças Armadas, notadamente o Exército atual, tem algumas semelhanças, mas também muitas diferenças, em relação àquelas existentes nos períodos Colonial, Imperial e no início do período republicano. E, a partir de lá, também houve um longo percurso para que chegássemos, hoje, ao que FAORO designa por doutrina da supremacia do Supremo Tribunal Federal - moderador único da onipotência dos presidentes, da harmonia dos Estados, e da supremacia militar." (FAORO, 1979:560)

93 Website Exército. Acesso em março/2006. Ressalta-se que segundo a Constituição da República Federativa do Brasil: Art. 142 - As Forças Armadas, constituídas pela Marinha, pelo Exército e pela Aeronáutica, são instituições nacionais permanentes e regulares, organizadas com base na hierarquia e na disciplina, sob a autoridade suprema do Presidente da República, e destinam-se à defesa da Pátria, à garantia dos poderes constitucionais e, por iniciativa de qualquer destes, da lei e da ordem. 
Acrescentamos, por fim, que em relação à aceitação das Forças Armadas por parte da população, um dado chama atenção. De acordo com pesquisa feita a partir de entrevistas em todo o País, as Forças Armadas obtiveram 75\% no índice de confiança da população brasileira, ficando apenas atrás da categoria "médicos". (IBOPE, 2003). Para o antropólogo Celso Castro, o fenômeno pode ser entendido da seguinte maneira:

A polícia tem uma relação mais próxima com as pessoas, enquanto as Forças
Armadas estão mais distantes, mais preservadas de escândalos, de casos de
corrupção, de ilícitos". Desde 1989, quando as Forças Armadas começaram a
ser avaliadas pelo lbope, a credibilidade da instituição só tem aumentado. Assim
como a diretora do Ibope, o pesquisador não acredita que essa valorização da
imagem das Forças Armadas possa ser confundida com um anseio de volta dos
militares ao comando do país. "Tanto é assim que, quanto mais o tempo passa,
desde que os militares ocuparam o poder no Brasil, mais eles se tornam
confiáveis. (Revista Carta Capital - número 358)

Este assunto, obviamente, exige uma reflexão mais aprofundada que foge aos limites desta pesquisa. Há vários elementos que devem ser levados em conta ao se avaliar a credibilidade de uma categoria. O que aqui queremos destacar é que a participação militar na fronteira, e aqui consideramos, em especial, o caso de Roraima, possui uma legitimidade por parte da população que pode ter algum grau de correspondência com a situação que se observa em âmbito nacional. Nossas pesquisas não são conclusivas a este respeito, mas os questionários aplicados em Boa Vista e Pacaraima - por ocasião de pesquisa de campo com alunos da UFRR - conduzem-nos a esta percepção inicial. ${ }^{94}$

Tomando como base a significância que os militares atribuem a si mesmos quanto ao papel que desempenham nas fronteiras e que, em certa medida, é compartilhado com setores importantes da sociedade, pode-se afirmar que há rupturas em relação às ações desenvolvidas no período de 1946-64 na fronteira norte.

As mudanças de concepção doutrinária são relevantes no que diz respeito à defesa externa, num período marcado por alianças e acordos de cooperação com países

\footnotetext{
94 Documentários, recentemente produzidos por alunos do Departamento de Comunicação da UFRR; bem como registros baseados na "história oral", têm apontado esta percepção diferenciada da atuação dos militares, mesmo durante a ditadura militar de 1964/84, em Roraima. Obviamente, estamos nos referindo a uma impressão geral da sociedade roraimense, sem uma avaliação específica dos setores ligados a questão indígena ou a outros atores da sociedade civil organizada, que em geral, não tinham expressão neste local no período considerado. Este fato também pode ser explicado, em forte medida, pela máquina administrativa instalada desde o território, ampliada durante o regime militar, cujos atores - servidores destacados para os cargos públicos neste Território Federal - provavelmente, no mínimo, mantiveram-se distante do ambiente repressivo e ditatorial das grandes cidades, e dos movimentos combativos ao regime militar desta época.
} 
da América do Sul e não apenas com os EUA, cuja aliança estratégica foi realizada no contexto da Guerra Fria.

Pode-se concluir ainda que há mudanças também em relação às políticas voltadas ao meio ambiente e à valorização do elemento étnico. O setor militar assumiu o discurso preservacionista na medida em que favorece o seu protagonismo na "selva inóspita", acessível a pouquíssimos atores, como se verá adiante. 


\section{III.2 De fortes e colônias militares à criação do CMA}

Desde o início da colonização, a questão da fragilidade da defesa do tão imenso e tão pouco povoado território amazônico fez-se notar em vários registros de viajantes, exploradores, cientistas, militares e outros mais que por aí se aventuraram.

$\mathrm{Na}$ fase inicial da colonização, como vimos, não havia, ainda, para tão grande área, sequer a definição de suas fronteiras, que só foram finalizadas no início do século XX. Até a assinatura do Tratado de Madri, em 1750, Portugal e Espanha ainda negociavam a posse dessa área.

$\mathrm{Na}$ área do Vale do Rio Branco, a construção do Forte de São Joaquim, no final do século XVIII, representou o primeiro projeto para efetivar a permanência de colonos na área, sob impulso do representante da coroa portuguesa, Manuel da Gama Lobo D'almada $^{95}$. Ele veio inicialmente designado pela Coroa portuguesa para realizar explorações geográficas, enquanto membro da Comissão Demarcadora de Limites, instituída pelo Tratado de Santo Ildefonso, estabelecido entre Portugal e Espanha em 1777.

Com o seu desempenho na referida Comissão, D'Almada, assumiu no ano de $1784,{ }^{96}$, o "Comando Militar" das Capitanias do Rio Negro. Sua fixação no vale do rio Branco, porém, se dará a partir de sua nomeação como governador da Capitania de São José do Rio Negro, no período de 1789/1799. Nesse período, o território que hoje pertence ao estado de Roraima pertencia ao Estado do Grão Pará. ${ }^{97}$

A intenção de marcar presença nesse vale, através de um marco concreto, já havia sido sinalizada pela coroa portuguesa duas décadas antes da criação do Forte, por ocasião do governo pombalino - ministro português no período de 1769-1782, no reinado de D. José (1750-1777).

95 Trata-se de um dos mais recorrentes mitos do pioneirismo, referenciado nos principais marcos da cidade de Boa Vista e do estado de Roraima. Nota-se que a maioria das fontes refere-se a Lobo D'Almada como geógrafo. Sabemos que nesse período, século XVIII, não havia uma distinção tão nítida no mundo das Ciências, como hoje a entendemos. As figuras proeminentes na ciência dessa época atuavam em várias áreas.

$96 \quad$ As datas nem sempre aparecem com precisão nos vários documentos consultados. Em alguns locais, D'Almada aparece como o próprio fundador e construtor do Forte São Joaquim. Mas, com base em pesquisa feita a partir de documentos de época, como as de FARAGE, N. (1991), tem-se a indicação que a trajetória política deste referido representante colonial inicia-se com sua nomeação para o cargo de comandante do "Comando Militar" do Alto Rio Negro, em 1884, enquanto o Forte foi inaugurado em 1778.

A partir de 1621, ao tempo da união das coroas ibéricas (1580-1640), a América Portuguesa foi dividida em dois "Estados": o do Brasil e o do Maranhão, que posteriormente teve parte desmembrada com a denominação de Grão-Pará. Este, a grosso modo, abrangia a Amazônia brasileira de hoje. (SANTOS, N.P.D, 2004:83) 
Tratava-se de uma estratégia mais ampla de modernização da administração colonial que se encontrava em franca decadência no final desse século. A maior parte da literatura existente sobre o assunto enfatiza que, no que se refere ao vale do Rio Branco, houve apenas a intenção portuguesa de assegurar o controle da bacia amazônica, já disputada pelas potências imperialistas da época. ${ }^{98}$

Somos da opinião, porém, que a situação econômica de penúria em que se achava o império colonial português, no final do século XVIII, tenha levado à busca de alternativas de uma nova política colonial, sobretudo em sua principal colônia, o Brasil. FAORO, descreve a situação econômica desse período dando ênfase à queda na exportação de produtos primários, em decorrência do esgotamento das minas e do colapso provocado pela baixa na exportação do açúcar, que passou a ser produzido em outras áreas coloniais. Outros aspectos, como a finalização do tráfico do escravo também explicam o desconcerto de Portugal diante de outras potências. (FAORO, 1979:227)

As análises deste autor apontam o final do século XVIII como um período de extrema crise do colonialismo português, cuja manutenção baseava-se num sistema obsoleto de "reinóis" que promoveram uma verdadeira pilhagem dos bens coloniais; não permitindo, assim, a formação de uma estrutura econômica autônoma nas áreas colonizadas.

Sendo, assim, novas formas de exploração colonial deveriam ser buscadas como alternativa para a restauração da soberania portuguesa, comprometida e ameaçada pelas devastações da Revolução Industrial - que assinala um novo marco na história moderna. (FAORO, 1975:228)

Nesse sentido, promover o povoamento, permitindo-se a formação de um mercado interno nas áreas coloniais, era uma das possibilidades da nova administração pombalina. Esse movimento obterá êxito somente após a expansão da cultura cafeeira, após a independência do País, bem depois do fim do governo de Pombal.

Em todo caso, este parece ser o contexto mais amplo no qual de enquadram as políticas de ocupação e defesa do vale do Rio Branco, no final do século XVIII, cujo elo se completava com a inserção permanente de dois poderes indispensáveis ao projeto colonizador: o poder das armas e o poder clerical.

\footnotetext{
98 Há uma série de obras de cronistas e de outras personagens que visitaram essa área nos primórdios de sua ocupação, como VON MARTIUS, C.F.; BAENA, Antônio L.M. (1839); SOUZA, Augusto F. (1885), FERREIRA, Alexandre Rodrigues, cuja obra: Viagem Filosófica pelas Capitanias do Grão Pará, Rio Negro, Mato Grosso e Cuiabá: 1783-1792, tornou-se um marco importante..
} 
Para FARAGE, no entanto, as preocupações pombalinas com a Amazônia devem ser entendidas no contexto do contrabando que já era praticado nas fronteiras da colônia. A autora não destaca, desta maneira, a defesa estratégica da área, ou seja, questões de soberania como propulsoras, em si, de uma política de fixação do povoamento no vale do rio Branco. Ela destaca que havia, sobretudo, uma preocupação com a falta de controle sobre as riquezas existentes e a perda de receita resultante das contravenções operadas nas fronteiras da colônia.

Assim, queremos relativizar as afirmações de que a origem da ocupação colonial no vale do rio Branco sejam de caráter eminentemente estratégico, pois os contingentes militares, propriamente ditos, como já analisamos no item III.1, eram extremamente precários e incapazes de realizar, por si sós, a defesa do vale.

Como já foi dito, a concepção do "militar" nessa época é bastante diferenciada do que temos hoje, sendo os próprios colonos precariamente armados para efetivar a ocupação dessa área e subjulgar os oponentes: indígenas, estrangeiros ou qualquer outra categoria de flibusteiros que se aventurasse por essas bandas.

Os fortins, construídos com os elementos que o meio permitiu, artilhados convenientemente, chegaram em mau estado ao Brasil-Império. Nos primeiros tempos do novo regime não sofreram os reparos necessários. Sua eficiência, consequentemente, era nenhuma. Viajantes que desciam ou subiam o Solimões, o Negro e o Branco, falavam dos estabelecimentos sorrindo do poder bélico que poderiam oferecer. Esboroados, valiam mais ou quase unicamente como documentários do passado, interessando antes à história militar, artística, mesmo porque jamais tinham tido ocasião de entrar em atividade cortando o passo a quem ousasse penetrar o território que deviam defender. Reduziam-se, como o de Tabatinga, a posto fiscal, identificando os estrangeiros que passava a fronteira $^{99}$

Nesse cenário, o então governador da Capitania do Rio Negro, Lobo D'Almada, já com a patente de coronel, introduziuo Vale do Rio Branco, em 1789, uma série de medidas objetivando a ocupação e a fixação de colonos na área. Para tanto, iniciou com a recuperação e dinamização do Forte, concentra sua atenção em outros projetos como a pecuária, cujo dinamismo à época permitiu o abastecimento de outras localidades na então Província do Amazonas. A primeira Fazenda Real foi constituída por D’Almada às margens do rio Uraricoera, abaixo da confluência com o Tacutu. Mais tarde, essa fazenda passou a ser chamada de Fazenda São Bento. (SANTOS, 2004:83)

99 REIS, Arthur César. Roteiro Histórico das fortificações no Amazonas. Revista do Serviço do Patrimônio Histórico, Artístico Nacional, n 6, RJ, 1942 
Garantir a presença militar na Amazônia, na conjuntura dos primeiros séculos de colonização, representava um alto custo. $\mathrm{Na}$ visão dos estrategistas da época, o custo poderia ser compensado pela perspectiva de suas riquezas naturais e pela posição estratégica na América do Sul. Nesse contexto, marcos vão sendo colocados em pontos estratégicos da região amazônica para expressar o interesse nesse imenso território. $O$ mais antigo deles é o Forte do Presépio, construído em Belém, no ano de 1616.

É a partir dessa visão que, em julho de 1753, o território da atual Amazônia brasileira recebeu, durante a reforma realizada por marquês de Pombal, dois regimentos provenientes de Portugal. Esses regimentos, instalados em Belém e Macapá, foram as primeiras unidades de um Exército permanente na Colônia. As dificuldades em mantê-los, no entanto, perdurou por séculos. E, somente em 1803, a Amazônia pode contar com um corpo de artilharia e uma guarnição militar de fato e de forma permanente, e que ademais, só guarneciam a estreita faixa de Belém e Macapá. ${ }^{100}$

O problema dessas medidas é que elas não tinham continuidade. Apesar de ter permanecido quase oito anos no Grão Pará, Mendonça Furtado - irmão de Marquês do Pombal - não implementou a reforma militar. (...) continuava a recorrer a forças militares recrutadas de última hora entre a população local. $O$ Pará só voltaria a receber um regimento do Exército em 1802, por conta dos conflitos fronteiriços com Caiena, entre Portugal e França. (CASTRO, 2006:55)

CASTRO afirma que, até 1822, para guarnecer toda Amazônia constava-se apenas com três regimentos de infantaria e um corpo de cavalaria. E acrescenta que durante mais de sessenta anos de regime monárquico no Brasil, esse perfil não se alterou muito, exceto em relação à presença de forças de Estado-Maior, pois, durante longos anos do Império, predominavam os batalhões, subunidades de um regimento" (CASTRO, 2006:58)

As forças militares responsáveis pela defesa das fortalezas e pelo interior da Amazônia, eram igualmente inexpressivas, até praticamente fins do século XIX, a defesa da Amazônia era realizada por pouco mais de 300 militares. CASTRO, \& SOUZA, A. B., 2006:58

Esses dados revelam que as poucas, frágeis e isoladas unidades militares em si não poderiam assegurar a integridade do território amazônico. Nesse sentido é que se pode afirmar que atuaram forças tão ou mais significativas, que em conjunto, permitiram a defesa e a ocupação dessa área. 
Ao lado dos militares e dos empreendedores econômicos, deve-se considerar a participação de missões religiosas ${ }^{101}$ nesse processo. Agrega-se ainda o poder da diplomacia brasileira que, através de acordos e tratados, asseguraram a expansão e manutenção das fronteiras do Brasil.

Os vários registros existentes não deixam dúvidas de que os religiosos, ao lado de outros representantes diretos da Coroa portuguesa, de fato facilitaram a ocupação, a expansão, e o domínio português. As diversas ordens religiosas que atuaram na Amazônia, desempenharam um papel central na preparação dos colonos e dos indígenas para o trabalho e para a vida religiosa, permitindo, assim, uma maior adequação desses atores ao universo ocidental cristão.

Segundo CASTRO, do século XVII ao XIX, trinta e sete fortificações militares foram implantadas pelos portugueses na Amazônia, mas, somente no início do século XIX foram instaladas unidades militares que garantiram a presença permanente de militares na região. Embora não disponhamos de dados comprobatórios, as leituras de várias fontes permitem sugerir que até este momento, a presença de missionários na Amazônia era maior que a de militares, efetivamente incorporados ao Exército.

A primeira colônia militar foi inaugurada em 1840 , na região do rio Araguari,
seguindo-se a instalação de outras como em São João do Araguaia, São Pedro
de Alcântara, Óbidos, Oiapoque e Tabatinga. Na perspectiva da construção do
território brasileiro, a Amazônia era tão importante quanto o Prata, já que o
Império enfrentava as ambições francesas e britânicas de acesso ao vale
amazônico, assim como as pressões dos Estados Unidos para o
estabelecimento da livre navegação internacional dos rios amazônicos. ${ }^{102}$

As colônias militares eram estabelecimentos compostos por contingentes militares e colonos civis e foram pensadas como um projeto centralizador do governo brasileiro, recém empossado, para a vigilância e o povoamento da fronteira amazônica, sob o impulso inicial da demarcação da linha de fronteira.

Na região do Guaporé (Contingente de Porto Velho), onde as colônias militares tiveram um dinamismo bem maior que na área do Rio Branco, temos um exemplo da organização de um núcleo agrícola, que foi ampliado em função da "rodovia de

\footnotetext{
101 Um artigo de OLIVEIRA, Adélia Engrácia, publicado no BMP Emílio Goeldi (1988), refaz o percursso da ocupação humana na Amazônia, do século XVII ao XX, apresentando vários dados a respeito das missões religiosas nessa área.

102 CAVAGNARI FILHO, G.L. Introdução à defesa da Amazônia. In: Artigo originalmente publicado em Carta Internacional, Funag-USP, ano X, nº 107/108, janeiro/fevereiro de 2002, pp.19-21
} 
penetração Amazonas-Mato Grosso", no ano de 1943, como afirma Ferreira no trecho que segue:

Nelles estão estabelecidas 25 famílias de patrícios egressos dos seringais, em lotes de 25 hectares, tendo cada um recebido uma lavoura de três hectares, em estado de produção e uma barraca para moradia.(FERREIRA, 1935) ${ }^{103}$

Até meados do século $X X$, os núcleos militares eram unidades muito incipientes, que mal contavam com uma base efetiva de pessoal devidamente incorporado às fileiras do Exército. Do período de criação das primeiras colônias militares (meados do século XIX), até meados da década de 1930, ainda não havia uma estrutura organizacional mais acabada de cargos, funções, comandos, ou até mesmo uma estratégia particular das Forças Armadas para as áreas de fronteira.

Os atos e os Decretos publicados durante o governo do presidente Getúlio Vargas (1930-1946), mostram que a partir deste governo, as preocupações militares com as áreas mais isoladas do País levaram à realização de um projeto destinado às mesmas. ${ }^{104}$

Somente os militares, na visão de Rocha ${ }^{105}$, conquistariam o desenvolvimento almejado, pois eram os únicos que reuniam condições de enfrentar crises econômicas, e de abastecimento. Enfatizou o esforço e a capacidade dos soldados e oficiais do Exército, personificados no cap. Aluísio Ferreira. Este fez surgir na fronteira a figura do soldado-cidadão, transcendendo o seu papel puramente militar. Os soldados lavravam a terra e criavam as infra-estruturas necessárias à ocupação e a colonização da região (SOUZA, 2002:91)

Em contraste, alguns autores visualizam a presença militar como modificadora da paisagem amazônica, bem antes desta data. MEIRELLES, por exemplo, afirma que a criação de núcleos militares na área dos vales do Guaporé/Mamoré foi incentivada a partir de 1907, através das Seções do Telégrafo Nacional, levadas adiante pela Comissão Rondon, que estabeleceu as bases para um sistema de comunicação com a capital da Republica. É desta época a criação do Serviços de Proteção ao Índio e a Localização dos Trabalhadores Nacionais/SPILTN. ${ }^{106}$

\footnotetext{
103 Relatório do Cap. Aluízio Ferreira, enviado ao comandante da $8^{\text {a }}$ Região Militar, appud SOUZA, 2002:41)

Decreto Lei ${ }^{\circ}$ 1164, de 1938; instalação dos contingentes especiais de fronteira; regulação das áreas de fronteira; criação dos territórios federais, etc. Nesta época também surgem leis, que visavam efetuar reformas básicas no Exército; regulamentação do Conselho de Segurança Nacional; organização geral do Exército, do Ministério da Guerra ."

105 Geraldo Rocha, diretor do jornal "A Noite", Rio de Janeiro.

106 Vide: MEIRELLES, Denise Maldi - Os guardiões de fronteira. Petrópolis/Vozes, 1989.
} 
$\mathrm{Na}$ verdade, não havia mão-de-obra disponível para a realização dos projetos "modernizantes", que começavam a ser instalados em áreas isoladas da Amazônia, nem mesmo as condições de incorporação, com salários, a todos aqueles que aparecem como "soldados" dos contingentes ${ }^{107}$. Assim, tanto os trabalhadores nordestinos que ficavam sem ocupação nos seringais e que curtiam franca decadência, quanto os indígenas que puderam ser "pacificados", transformavam-se em potenciais soldados, sem vínculo oficial com o Exército. ${ }^{108}$

Se levarmos em consideração a situação particular de algumas áreas, como os vales do Guaporé/Mamoré que têm um dinamismo econômico, social e político bem diferente daquele estruturado no vale do Rio Branco, podemos visualizar a participação militar na estruturação territorial desse espaço num momento bem anterior ao marco temporal acima proposto, ou seja, a partir do governo Vargas. Mas, a presença oficializada e ampliada de bases militares na região amazônica tem data mais recente, como se verá.

Tratando do caso do "Guaporé", em sua dissertação de mestrado SOUZA descreve com muita perspicácia os principais eventos que levaram a uma estruturação da vida política social e econômica nessa área. Tomando como base a trajetória do Ten. Aluísio Pinheiro Ferreira, designado em 1930 para a chefia do Distrito Telegráfico da Seção Norte, o autor afirma que:

Com a Revolução, (Ten. Aluízio) é nomeado delegado de Vargas na região dos vales e do estado do Amazonas. Em 1931 foi nomeado diretor da ferrovia administrada pela empresa Madeira Mamoré Railway and. Co. À frente desta ferrovia, intercede junto ao Ministro da Guerra para a criação de três contingentes especiais de fronteira, acumulando o cargo de Inspetor dos Contingentes. Era o representante da União controlando os órgãos vitais na região. Em 1943 é nomeado o primeiro governador do Territorio Federal do Guaporé. ${ }^{109}$

Além disso, há e se considerar a presença dos famosos "coronéis de barranco" ou seringalistas, que atuaram nesta região eram verdadeiros caudilhos políticos. Durante a Segunda Guerra Mundial eles passaram a atuar como chefes militares, controlando a produção e os movimentos do "Soldado da Borracha". Neste sentido, o significado do que

O "Contingente Especial de Fronteira” possuía em média: um sargento, dois cabos e 20 soldados. Somente os oficiais eram comissionados. Os demais, sobrevivam dos recursos que conseguiam angariar com os trabalhos nas colônias agrícolas, confundidas com a própria colônia militar.Por outro lado, este contingente era muito variável, dependendo das circunstâncias em que necessitavam mais ou menos mão de obra.

108 Vide a tese de FREITAS, Edinaldo B. Índios-Soldados: A GRIN e a tradição militar da política indigenista brasileira. Tese de Doutorado em História Social, FFLCH/USP, SP, 1999

109 SOUZA, V.A. (2002:34) Des (ordem) na fronteira 
seja militar na região, assume uma maior complexidade, e talvez confusão semântica, para muitos.

Como já foi sugerido anteriormente, as realidades amazônicas sempre foram bem distintas, o que acarreta que cada área funcionasse como uma espécie de "ilha", com pouca conexão entre os "Centros". Esses Centros foram-se constituindo em torno de surtos econômicos, que ora privilegiavam um, ora outro produto, para o mercado externo. Nesse sentido, a economia do vale do Rio Branco, que não fez parte dos circuitos mais importantes da região, ficou relegada a segundo plano pelas elites regionais, às quais subordinou-se até meados do século $X X$, e, muito mais pelo poder central, que ainda não estendera suas malhas de transporte e de integração até este vale.

O recente foco na defesa e segurança da Amazônia, incluindo o Território Federal do Rio Branco, inclui-se num pacote de medidas de estruturação das Forças Armadas, estabelecido no ano de 1956, quando foi criado o Grupamento de Fronteira, em Belém do Pará, com subunidades em áreas de selva - os pelotões especiais de fronteira - PEFs. Concorreram para tanto outras medidas que complementam as políticas anteriores de colonização agrícola pecuária ou de outro tipo praticado na Amazônia, em datas anteriores.

As Forças Armadas passaram a desempenhar um papel crucial na consolidação da ocupação territorial da Amazônia a partir desse momento, quando passaram a ter um mandato oficial mais abrangente e claro em relação a todos os aspectos da vida local sob sua interferência direta. Este mandato estruturou-se, no entanto, desde os anos 1930, a partir de uma forte propaganda aliada à atuação direta de alguns militares que se destacaram no "bandeirantismo do norte".

Dentre os vários órgãos de propaganda da época destacamos, abaixo, o jornal carioca "A Noite", por ser à época a própria voz da elite do país, concentrada na "corte" do Rio de Janeiro.

No Rio de Janeiro, merecem destaque, o jornal "A Noite", com a coluna Territórios de Fronteira, mantido pelo jornalista Geraldo Rocha, grande "divulgador oficial" dos vales do Madeira-Guaporé e da atuação do Cap. Aluízio Ferreira. Entre 1931 e a criação do território em 1943, Rocha escreveu um total de 15 artigos, posicionando-se sobre a concessão de terras, ocupação militar, $e$ criação de território. As pequenas elites seringalistas locais estavam "sintonizadas" com a imprensa carioca, manauense e paraense.(...) $O$ artigo, "A sentinella do Oeste", transcrito do jornal "A Noite" para o jornal "Alto Madeira", em 1936, era uma referência aos Contingentes Especiais de Fronteira do Guaporé." (SOUZA, 2002:80) 
Após a instauração do Estado Novo, em 1937, iniciou-se uma série de visitas de autoridades civis e militares às áreas de fronteira, em função, inclusive, da inauguração da linha aérea entre Cuiabá e Rio Branco, em 1938. A partir da constatação, in loco, da realidade na fronteira norte, o Conselho de Segurança Nacional, criado por Getúlio Vargas, elaborou projetos de criação de territórios nessa área, embora as ações efetivas para ocupação da área ainda permanecessem no nível do discurso.

(...) Urge, pois, a creação de Territórios fronteiriços que, occupados por militares da envergadura de Aloyzio Ferreira, elevem a missão do nosso Exército, assegurando a integridade de nosso solo e desbravando, para a civilização, os férteis rincões das nossas fronteiras, abrindo os caminhos futuros da nossa expansão. Mato Grosso, Amazonas, Pará, são regiões demasiado vastas para as populações reduzidas que as ocupam. Estas imensas unidades administrativas, occupando territórios fronteiriços constituem um perigo para a segurança nacional.

Devemos proteger as nossas fronteiras desertas, dividindo-as em Territórios, com a sua jurisdição entregue ao Exército Brasileiro."

Embora tenhamos dado destaque especial ao papel desempenhado por militares do Exército na ocupação da Amazônia, devemos considerar que, após a criação do Correio Aéreo Nacional, sobretudo no caso de Roraima, a Aeronáutica passou a desempenhar um papel fundamental na consolidação do futuro Estado.

A atuação do Correio Aéreo Nacional, a construção de linhas telegráficas e de estradas, desde as primeiras décadas do século XX, estabeleceram a conexão da Amazônia com o Centro-Oeste e com o resto do Brasil, alterando de forma brusca a paisagem local, antes só alcançada através dos rios.

110 Artigo: "Territórios de fronteira" Jornal Alto Madeira. Porto Velho, 30/03/1938. Transcrito de Geraldo Rocha: “A Noite”, de 14/02/1938. (SOUZA, 2004:89) 


\section{CAPÍTULO IV}

\section{ATUAÇÃO DAS FORÇAS ARMADAS EM RORAIMA}

\section{IV.1 O CMA e a atuação das Forças Armadas em Roraima}

Conforme demonstramos, não obstante a existência anterior de outras formas de defesa e de segurança implantadas em áreas estratégicas do País, que é caso dos fortes, a efetiva ocupação militar teve início somente no século XIX, com a instalação da primeira colônia militar na região do rio Araguari, localizado no atual estado do Amapá, em $1840^{111}$.

O sistema de defesa atual surgiu no final do século XIX e no início o século $X X$, quando o desenvolvimento econômico passou a se concentrar na região sudeste do País e a Amazônia ainda estava completamente isolada das políticas territoriais existentes à época. Essa ausência de políticas acabou gerando em alguns meios, a exemplo do militar, a preocupação com a soberania dessa área, como se percebe no excerto abaixo:

Às Forças Armadas coube a iniciativa da articulação da Amazônia com as áreas mais avançadas da economia brasileira, com o propósito de defendê-la da cobiça internacional - porque já estavam presentes, segundo o discurso militar, as ameaças de sua internacionalização. ${ }^{112}$

Foi nesse contexto que as antigas colônias militares foram sendo substituídas por pelotões de fronteira, mais adequados ao emprego estratégico de defesa e de segurança do território. A figura abaixo representa os pontos onde se localizam os atuais Pelotões Especiais de Fronteira-PEFs da Amazônia brasileira.

\footnotetext{
${ }^{111}$ Até esta data, a Amazônia era guarnecida basicamente por apenas três regimentos de infantaria e um corpo de cavalaria. Cento e quarenta anos depois (1980), ainda não havia mais de quatro mil militares na região, conforme palestra do general Raimundo Nonato. (CMA, abril/2004)

${ }^{112}$ CAVAGNARI FILHO, G.L. Introdução à defesa da Amazônia. In: Artigo originalmente publicado em Carta Internacional, Funag-USP, ano X, nº 107/108, janeiro/fevereiro de 2002, pp.19-21
} 


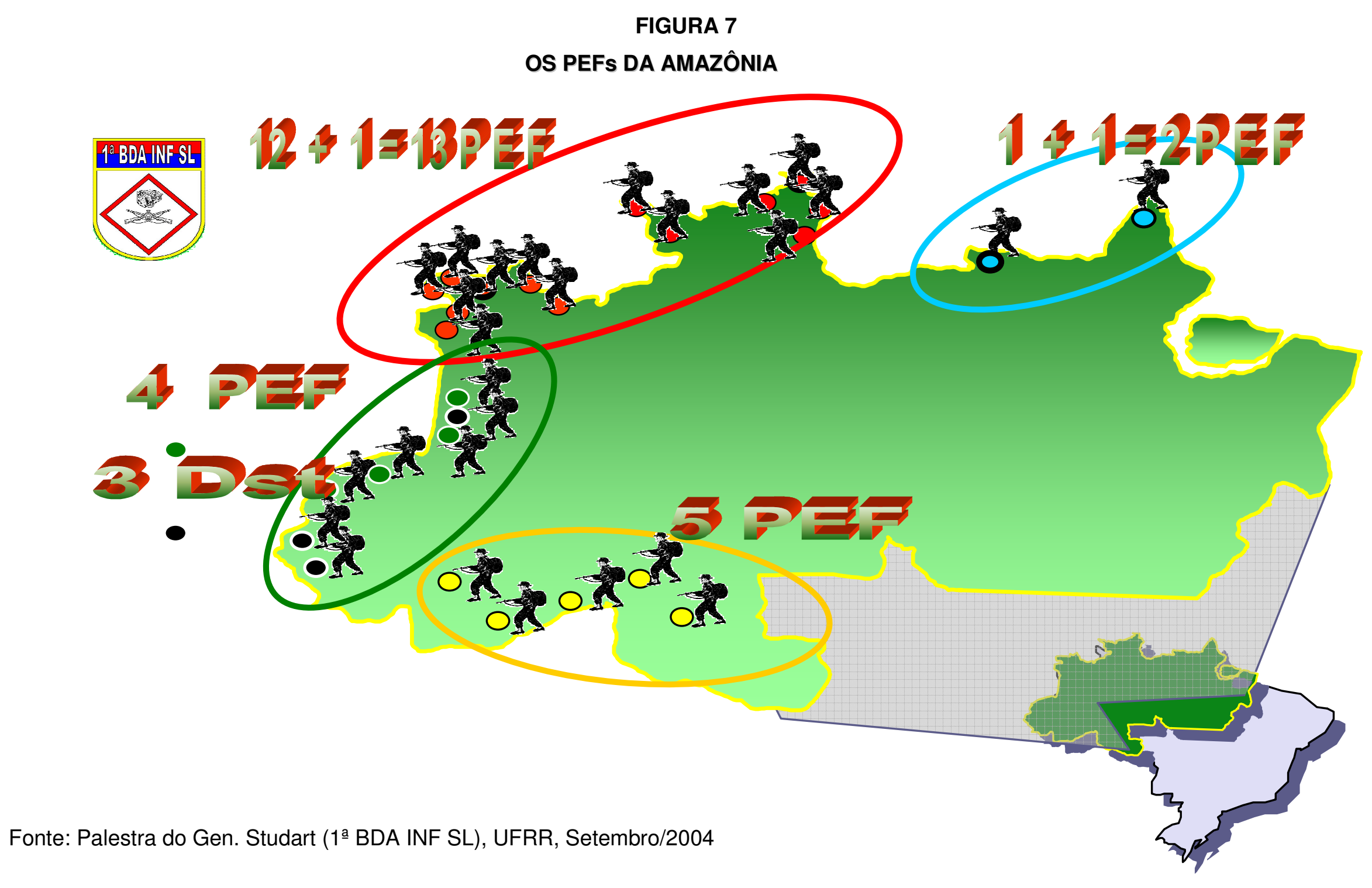


Até a década de 1940, a estrutura da força terrestre permaneceu centralizada nas antigas capitais brasileiras do Nordeste e no Rio de Janeiro. Somente em 1945, o Exército Brasileiro modernizou sua estrutura administrativa e operacional, estabelecendo quatro Zonas Militares: Norte, Centro, Oeste e Sul, as quais, por sua vez, subdividiram-se em Regiões Militares.

Atualmente, o Exército Brasileiro possui o seguinte organograma:

- Comando Militar da Amazônia CMA, com sede na cidade de Manaus - AM e jurisdição sobre os territórios das $8^{\mathrm{a}}$ e $12^{\mathrm{a}}$ Regiões Militares;

- Comando Militar do Nordeste - CMNE, com sede na cidade do Recife e jurisdição sobre os territórios das $6^{\underline{a}}, 7^{\mathrm{a}}$ e $10^{\mathrm{a}}$ Regiões Militares;

- Comando Militar do Oeste - CMO, com sede na cidade de Campo Grande- MS e jurisdição sobre o território da 9a ${ }^{a}$ Região Militar;

- Comando Militar do Planalto - CMP, com sede na cidade de Brasília - DF e jurisdição sobre o território da $11^{\text {a }}$ Região Militar;

- Comando Militar do Leste - CML, com sede na cidade do Rio de Janeiro - RJ e jurisdição sobre os territórios das $1^{\text {a }}$ e $4^{\underline{a}}$ Regiões Militares;

- Comando Militar do Sudeste - CMSE, com sede na cidade de São Paulo - SP e jurisdição sobre o território da $2^{\underline{a}}$ Região Militar; e

- Comando Militar do Sul, CMS - com sede na cidade de Porto Alegre- RS e jurisdição sobre os territórios das $3^{\underline{a}}$ e $5^{\underline{a}}$ Regiões Militares

Até a década de quarenta, as regiões militares do Comando ${ }^{113}$ Militar da Amazônia e do Nordeste brasileiro estavam submetidas à Zona Militar do Norte. A Zona Militar do Norte abrangia as $6^{\underline{a}}, 7^{\underline{a}}, 8^{\underline{a}}$ e $10^{\underline{a}}$ Regiões Militares, constituindo, assim, uma imensa área militar que englobava todos os estados do Nordeste e da Amazônia.

O embrião do Comando Militar da Amazônia (CMA) tem sua referência mais remota no ano de 1948, com o então Comando de Elementos de Fronteira, sediado em Manaus. Em 1957, passou a denominar-se de Grupamento de Elementos de Fronteira (GEF), com sede em Belém.

Somente no ano de 1969, o CMA adquiriu um novo formato. Fixando a sede em Manaus e dispondo de bases logísticas sediadas em Boa Vista, Tefé, Porto Velho e Marabá/PA, o Comando ficou responsável pelos territórios da $8^{\underline{a}}$ e da $12^{\underline{a}}$ Regiões Militares, sediadas em Belém e Manaus, respectivamente, como atesta o trecho que segue.

Em 1969 o CMA muda sua sede para Manaus, onde permanece até os dias atuais. Com o passar dos anos, o CMA cresceu de importância no cenário

${ }^{113}$ É denominado Comando Militar o agrupamento de Regiões Militares, sob um único comando regional. 
nacional e, hoje, engloba organizações militares de todas as armas e serviços (...), e guarnece mais de onze mil quilômetros de fronteiras com sete países sulamericanos. (...) com um contingente, de aproximadamente 22 mil militares, em uma área de responsabilidade que se estende pelos Estados do Acre, Amapá, Amazonas, Pará, Rondônia, Roraima e partes do Tocantins e do Maranhão. ${ }^{114}$

A partir de 1969, a nova ênfase militar no oeste da Amazônia se justificava em face da conjuntura política e ideológica da "Guerra Fria" que se desenrolava no continente americano e que teve como um dos fatores centrais a independência da Guiana, em 1966.

Com um cenário político instável; aumentava o receio de que o regime socialista viesse a ser implantado neste, como em outros países da área do Caribe e da América Latina, que também viviam situações politicamente conturbadas. Dentre outros temores que envolviam essa parcela da fronteira norte do Brasil, adicionavam-se a esse clima de instabilidade as disputas territoriais entre Guiana e Venezuela, na área do rio Essequibo ${ }^{115}$.

Segundo Nélvio Dutra: no final da década de 1960, o clima no Caribe era explosivo e a posição estratégica de Roraima deve ter pesado na mudança do Comando Militar da Amazônia de Belém para Manaus, a apressar a abertura da BR 174 e deslocar vários contingentes militares para a fronteira com a Guiana e a Venezuela. (SANTOS, 2004:122) $)^{116}$

\section{Segundo CAVAGNARI FILHO a}

ampliação e o fortalecimento da presença militar na Amazônia foram determinados, de certo modo, segundo a lógica que enfatizava a "hipótese da conquista" do espaço amazônico pelas grandes potências o que implicaria, obviamente, ocupação efetiva do território. Essa "hipótese" teve algum relevo quando os Estados Unidos realizavam exercícios militares na Guiana, como se eles fossem o prelúdio da aplicação da "teoria do cerco" à Amazônia brasileira."

$\mathrm{Na}$ visão de quem vivia o cotidiano do antigo Território Federal de Roraima, muita coisa mudou na década de sessenta. Segundo relatam, ao mesmo tempo em que estarrecia ver as tropas nas ruas, o controle da imprensa, as trocas freqüentes de

\footnotetext{
${ }^{114}$ Website www.timbo.eb.br. Acesso em dezembro/2004

${ }^{115}$ Uma análise dessa disputa entre a Venezuela e a Guiana foi feita por GARAVANI, S. (1988). Política Externa de Guyana. Caracas, Universidad Simon Bolívar.

${ }^{116}$ Historiador e professor no Departamento de Ciências Sociais, da UFRR.

${ }^{117}$ CAVAGNARI FILHO, G.L. Introdução à defesa da Amazônia. In: Artigo originalmente publicado em Carta Internacional, Funag-USP, ano X, n 107/108, janeiro/fevereiro de 2002, pp.19-21
} 
interventor federal, dentre outros efeitos adversos do Regime Militar, se percebia, ao mesmo tempo, a construção da estrutura material que passou a dinamizar a economia local.

Segundo depoimento do Capitão Damásio ${ }^{118}$, até a década de 1960 , o total do efetivo militar no território de Roraima não ultrapassava cem pessoas ${ }^{119}$. Além disso, contava apenas com dois caminhões e três gipes para atender a todas as demandas do território roraimense. Somente a partir do final desta década, foram deslocados militares de outras áreas para a fronteira com a Guiana, dando origem aos $1^{\circ}, 2^{\circ}$ e $3^{\circ}$ Pelotões Especiais de Fronteira, localizados em Bonfim; Normandia e Surumu, respectivamente.

No final da década de 1960, a quantidade de efetivo dá um grande salto e passa a constar de aproximadamente mil e quinhentos militares. Os dois fatos mais marcantes desse momento foram a transformação da 9 a Cia Fron em CFR/ $2^{\circ}$ BEF, em 1969, com a incorporação de seiscentos e setenta e nove militares; e a vinda do 6을 $\mathrm{BEC}$, com o aumento de mais setecentos e vinte e quatro militares, no ano anterior. ${ }^{120}$

Já na década de 1980, o efetivo não sofreu grandes alterações. Com a criação do $12^{\circ}$ Esquadrão de Cavalaria Mecanizado, em 1982, cento e noventa e cinco militares somaram-se aos que já estavam no Território Federal de Roraima; e mais setenta e um foram incorporados com a criação do 4 PEF, baseado em Surucucu, no ano de 1988.

Para completar este quadro, na década de 1990 o efetivo aumentou para dois mil, trezentos e setenta e oito militares, em decorrência de transferências e da criação de novos comandos em Roraima. Desta feita, em novembro de 1991 foi desativada a $1^{\text {a }}$ Brigada de Infantaria Motorizada, de Petrópolis (RJ), a qual foi reativada em Boa Vista, como $1^{\text {a }}$ Brigada de Infantaria de Selva (1992). ${ }^{121}$

\footnotetext{
${ }^{118}$ Capitão Damásio está atualmente na reserva do Exército. Ele nasceu em 1943, no então Território do Rio Branco, e acompanhou de perto a dinâmica de instalação de unidades militares em Roraima. Foi soldado do primeiro pelotão em Normandia (1968).

${ }_{119}$ Dados levantados no $7^{\circ}$ BIS, estimam que com a criação da $9^{\text {a }}$ Companhia de Fronteira em 1961, foram incorporados 160 militares.

${ }^{120}$ Dados aproximados, segundo quadro elaborado pelo Cel. Fontoura, por ocasião da entrevista com a autora, em junho/2006.

121 Para uma idéia geral, uma Brigada, possui cerca de 3.000 homens, um Batalhão de Infantaria, cerca de 600 homens. Segundo informação do Capitão Vicente de Paulo Souza da Silva, em maio/2005, o total de cada PEF em Roraima é de sessenta e seis homens. Sendo trinta e cinco do Pelotão de Fuzileiros de Selva, responsáveis pela parte operacional, e uma Seção Administrativa com trinta e um homens.
} 
Em janeiro de 1992, o $2^{\circ}$ Comando de Fronteira de Roraima/2o BEF foi transformado em Comando de Fronteira de Roraima / 7ํㅡㄹ Batalhão de Infantaria de Selva $7^{\circ} \mathrm{BIS}$. Esse destacamento adquiriu um novo status. Ademais, foram criados a $1^{\underline{a}}$ Base Logística de Selva, em 1993; o $5^{\circ}$ PEF em Auaris, em 1995, e o 33ํGrupo de Artilharia de Companhia de Selva, em 1996.

A partir do 2000, foi registrada a vinda do $10^{\circ}$ Grupo de Artilharia de Companhia de Selva, que se efetivou em 2002. No mesmo ano, se deu a criação do 6 PEF, em Uiramutã, perfazendo, assim, um total de dois mil seiscentos e quatorze militares. ${ }^{122}$

Atualmente, existe o consenso de que a Amazônia, com seus onze mil km de fronteiras com sete países da América do Sul, abrangendo uma área total de mais de cinco milhões de $\mathrm{km}^{2}$, é área prioritária para a defesa do País. $\mathrm{Na}$ atualidade, os desafios colocados para a Amazônia fizeram com que o quadro de militares fosse ampliado consideravelmente nessa área. Hoje são aproximadamente vinte e cinco mil militares que atuam nessa área. ${ }^{123}$

Tendo em vista esta percepção estratégica, em agosto/2004 foi efetivado o deslocamento da $2^{\underline{a}}$ Brigada de Infantaria Motorizada do município de Niterói/RJ para São Gabriel da Cachoeira/AM, na calha do Rio Negro, o que confirma a prioridade estratégica dessa extremidade ocidental da Amazônia.

O Comando Militar da Amazônia (CMA), que operava com pouco mais 10 mil homens no início dos anos 90, tem hoje de 25 mil a 27 mil soldados. Ao fim de 2005 serão cerca de 30 mil. ${ }^{124}$

Atualmente, o efetivo o Comando Militar da Amazônia possui, aproximadamente, 25 mil homens, numa área de responsabilidade que se estende pelos Estados do Acre, Amapá, Amazonas, Pará, Rondônia, Roraima e partes do Tocantins e do Maranhão.

Percebemos que há divergências quanto aos números apresentados nas diferentes fontes pesquisadas. Em todo caso, a confusão numérica, sobretudo quando

\footnotetext{
${ }^{122}$ Como já salientado estes dados foram retirados de cálculos aproximados, realizados pelo $7^{\circ}$ BIS. Podemos dizer que o efetivo atual do Exército em Roraima seja de três mil militares, considerando-se os incorporados temporariamente. É importante também observar que pode haver pouca precisão nos termos "transferência" e "criação", pois em outras fontes encontramos o mesmo evento sendo considerado de forma diferente. É comum também que os anos de criação sejam sempre citados com divergência, em vista, muitas vezes, de se considerar o ano do decreto e não o ano da concretização do ato, propriamente dito. Além disto, como exposto no primeiro capítulo, muitas informações só chegam através da imprensa e das falas de oficiais, de modo que, oralmente, os dados, quase sempre aparecem de forma genérica.

${ }^{123}$ In: Governo ampliará o controle na fronteira Norte. Folha SP, 05/05/2004. O Exército é a força singular dotada de maior efetivo - cerca de 200.000 homens em todo o país.

${ }^{124}$ In: Governo reforça presença em fronteiras - Estado de SP 13/08/2004
} 
divulgada pela mídia, se dá pelo fato de não se distinguir claramente se o efetivo é do Exército - que é o maior - ou se é o total das Forças Armadas, ou ainda se se trata apenas de "soldados", não incluindo outras categorias.

Em palestra proferida no Senado, o Almirante Davenas afirmou que

só o Exército tem mais de 30 mil homens na Amazônia. Em várias regiões, eles chegaram antes do juiz, do delegado ou do posto de saúde. As Forças Armadas representariam apenas o Estado Brasileiro na região, mas acabaram incorporando tarefas exclusivas do Governo Brasileiro, ligado às metas de desenvolvimento sustentável. Os militares têm convênios com todos os ministérios, incluindo o do Meio Ambiente, de Marina Silva."

Mais adiante afirma: "Estamos tentando mandar mais homens para a região, fazer mais bases na região da fronteira, mas com o orçamento que recebemos fica complicado. É baixíssimo", disparou Davena. Segundo o almirante, nos últimos 40 anos a presença de militares brasileiros na Amazônia passou de mil para 25 mil soldados. Além disso, a Marinha passou a utilizar 16 navios - antes eram apenas sete. (Correio Brasiliense 08/04/2005)

Sobre as perspectivas para Roraima, em entrevista, à Folha de Boa Vista de 20/04/05), o General Studart afirmou que há previsão de recebermos futuramente - talvez em três ou quatro anos - mais um batalhão a ser instalado na área de Caracaraí, com aproximadamente mil homens. Isso significa aumentar o estado de defesa que o Exército proporciona na região Norte.

Para CAVAGNARI FILHO, atualmente o dispositivo militar na Amazônia abrange vinte e cinco mil combatentes, sendo o maior efetivo o do Exército, com cerca de vinte e três mil homens. (Ibidem). A variação nesses números, deve-se às incorporações de curto prazo, de jovens que não são efetivados no serviço militar após o período que varia de um a sete anos, que é o prazo máximo que o militar pode permanecer no Exército sem ser efetivado.

A meta do Exército nos últimos anos é aumentar significativamente o efetivo militar na Amazônia, através da transferência de unidades do sul do País. As conseqüências podem ser sentidas, a ponto de atualmente esse efetivo representar doze por cento de todo o contingente nacional. 
Segundo depoimento do general Francisco Albuquerque, o Sul deixou de ser o foco de atenção principal do Exército, que se voltou para a Amazônia, considerada agora estratégica e prioritária. ${ }^{125}$

Temos 5 mil homens na fronteira nesta região e 23 mil em toda a área amazônica. Queremos elevar para 25 mil e, aos poucos, precisamos deslocar mais gente para outros pontos estratégicos da Amazônia, reforçou o ministro da Defesa, José Viegas Filho. (Ibidem).

Segundo concebem especialistas do setor militar, alguns fatores explicam esse reforço de contingentes na região amazônica. $O$ mais forte deles diz respeito à preocupação com a possível perda de soberania brasileira nessa área. Esse discurso sempre faz referência à participação dos Estados Unidos em questões de segurança na Colômbia e se complementa dando ênfase à importância que o governo brasileiro tem dado às questões sócio-ambientais dessa região com o apoio financeiro acompanhado de ingerência externa. $O$ segundo argumento completa o cenário geo-estratégico do qual os militares se ocupam nos dias de hoje, como se verá adiante.

Para José Roberto Martins, na gestão do Ministro Geraldo Quintão ${ }^{126}$, a defesa da Amazônia não só assumiu lugar central, como ficou mais evidente a vinculação desse aspecto da política de defesa nacional com a questão colombiana e a conseqüente preocupação de evitar eventuais tentativas norte-americanas de alinhamento automático dos países sul-americanos com as prioridades da segurança nacional dos EUA. (CASTRO, 2006:20 e 21)

Foram realizadas várias audiências públicas no Congresso Nacional com a participação de parlamentares e de autoridades militares com o objetivo de delinear uma política que correspondesse a esse novo cenário.

Do exame desses debates foi possível extrair uma constatação. Cada vez mais, as percepções de ameaça, que antes focavam um genérico risco de intervenção dos países ricos devido a pressões de opinião pública mundial, passaram a se concretizar num cenário e numa situação mais concreta: a política norteamericana de combate ao narcotráfico na Região Andina, cuja maior expressão foi o chamado Plano Colômbia, que trouxe em seu bojo uma intensificação das pressões dos Estados Unidos no sentido da participação decidida das Forças Armadas no combate ao narcotráfico. Filho (In: CASTRO, 2006:13)

Adiante, o autor afirma que a guerra contra o terrorismo, pós-onze de setembro de 2001, colocou a Colômbia num plano secundário. Paradoxalmente, porém, essa

\footnotetext{
${ }^{125}$ In: Governo ampliará o controle na fronteira Norte. Folha SP, 05/05/2004

${ }^{126}$ Assumiu a pasta do Ministério da Defesa, no governo FHC, no período de 2000 a 2002.
} 
depreciação do país andino coincidiu com uma nítida e rápida ampliação da dimensão e do propósito da ajuda militar. (...) Nesse novo quadro, o governo do presidente Bush avançou um passo que seu antecessor não ousara dar: em agosto de 2002, uma mudança na legislação americana ampliou o propósito da assistência letal para incluir o "contraterrorismo". (CASTRO, 2006:25)

A partir da constatação da importância dessa área fronteiriça, várias ações têm sido propostas, dentre elas o aperfeiçoamento de doutrinas de emprego militar na região, a exemplo da "estratégia da resistência", que seria uma espécie de guerra de guerrilha, que exige grande preparo e conhecimento do ambiente de selva para enfrentar um poder militarmente superior.

Além disso, desde o final da década de 1990, várias operações militares conjuntas têm sido realizadas em áreas fronteiriças pelas três forças, visando ao adestramento e ao combate a ilícitos que ocorrem nessas áreas, como as operações Timbó e Ajuricaba, realizadas, a partir de 2002, na Amazônia. Ressalte-se ainda a modernização dos equipamentos, veículos e estrutura militares, como se verá adiante.

O Programa "Operações Militares" foi introduzido no PPA 2000/2003. Com um planejamento inicial de trinta e dois milhões de reais foi contemplado na LOA $2003 \mathrm{com}$ quinze milhões, o que obrigou à reformulação das ações com redução das metas iniciais. Posteriormente, como conseqüência da aplicação do Decreto no 4.591/2003, o limite autorizado foi reduzido para dez milhões.

Isso propiciou que o Exército, além de reiniciar a renovação dos seus meios, pudesse começar a implantar quatro novas brigadas de infantaria de selva, de forças especiais. Implementou também o programa "Soldado-Cidadão", dando formação profissional a trinta mil jovens recrutas em 2004.

A Força Aérea também tem podido prosseguir com a modernização da sua frota de aviões, que inclui a substituição dos Mirage, a incorporação de novos supertucanos, de aviões de patrulha e de transporte e, ainda, a modernização das aeronaves AM-X e F-5. Por outro lado, a Marinha está retomando o programa de construção de submarinos, corvetas e fragatas.

Apesar do interesse geo-estratégico pela Amazônia e das diversas políticas integracionistas, durante o Regime Militar a estrutura militar implantada na Amazônia era 
ainda muito incipiente se considerarmos a ênfase atribuída à defesa. Somente a partir de meados de 1980, com o deslocamento de tropas para a região e com a criação dos Programas Calha Norte, SIVAM e SIPAM é que as Forças Armadas vêm assumindo ações de amplitude em outras políticas sociais, não exclusivamente de caráter militar.

As dimensões assumidas pelo setor militar na Amazônia devem ser compreendidas sob o ângulo peculiar das políticas brasileiras para o território nacional ${ }^{127}$. Em áreas distantes e isoladas dessa região, é fácil observar o "vazio de poder" institucional, que acaba sendo preenchido pela única força capaz de adentrar essas áreas, qual seja: o Exército. Isso ocorre graças à estrutura adquirida ao longo dos anos de vigência das políticas integracionistas e de "vivificação" das fronteiras.

Do ponto de vista do Comando Militar da Amazônia, o quadro atual responde às demandas estratégicas apontadas. O CMA está distribuído e presente em sessenta e duas localidades da Amazônia ${ }^{128}$, compreendendo cento e vinte e quatro unidades no interior desses municípios. São vinte e sete Pelotões Especiais de Fronteira-PEFs, com uma média de quarenta a sessenta homens, cada um, e cinco brigadas de infantaria de selva (BIS), que são comandos maiores, aos quais estão subordinadas as unidades operacionais do Exército:

- 1 a Bda Inf SI - Boa Vista - RR

- $17^{\text {a }}$ Bda Inf SI - Porto Velho - RO

- 16a Bda Inf SI - Tefé - AM

- $2^{\text {a }}$ Bda Inf SI - São Gabriel da Cachoeira - AM

- 23a Bda Inf SI - Marabá - PA ${ }^{129}$

As brigadas têm normalmente um ou dois pelotões na linha de fronteira e mais um recuado, os quais são apoiadas por unidades logísticas estrategicamente dispersas pelo território. No geral, os países mantêm as brigadas ou batalhões mais afastados em relação à linha de fronteira. Nessa linha permanecem apenas os pelotões, que são unidades fixas, que podem ser apoiadas por unidades preparadas para o deslocamento em situações emergenciais. A Brigada de Marabá, por exemplo, foi estruturada para

\footnotetext{
${ }^{127}$ É importante destacar, dentro do organograma do poder instituído, a necessidade os militares encontrarem um campo de relevo para sua atuação, após seu afastamento do comando direto da nação. A bibliografia a esse respeito é bastante vasta, tais como: CAMBESES JÚNIOR, M. (1999); COSTA, E.P.Lazzarotti (1994); MARTINS FILHO, J.R. (2003), dentro outros.

${ }^{128}$ O Website do CMA traz uma relação das sessenta e duas localidades através das quais as Organizações Militares se fazem presentes na Amazônia.

${ }^{129}$ A partir de dados disponíveis em CD Room, doado durante visita feita ao CMA, em Manaus, pudemos observar que as "Brigadas de Infantaria de Selva são preparadas para o combate convencional e o combate na selva.
} 
deslocar-se para qualquer ponto da Amazônia, podendo ser apoiada pelas brigadas de Recife e de Goiânia.

A Brigada ou "Batalhão de Tabatinga", no Amazonas, constitui uma exceção, tendo em vista a fragilidade dessa área enquanto ponto central do narcotráfico e de outros ilícitos comuns nesse ponto da fronteira Brasil/Colômbia. O Brasil mantém um intercâmbio de cooperação com o Comando de Brigada da Colômbia, localizada na cidade gêmea de Letícia, podendo realizar esforços conjuntos de controle dessa fronteira.

Dentre as grandes unidades operacionais, a $8^{\circ}$ e a $12^{\circ}$ Regiões Militares, sediadas em Belém e Manaus, respectivamente, compõem os comandos logísticos-administrativos que atendem a todo o escopo territorial do CMA. Essas duas unidades são apoiadas por organizações militares (OM) que prestam assistência à saúde e à educação, dentre outras. Além disso, o CMA conta com um Centro de Instrução e Guerra na Selva /CIGS, que oferece cursos de treinamento na selva em regime de cooperação e de intercâmbios com vários países do mundo.

O mais importante destacamento militar do CMA na Amazônia Ocidental ${ }^{130}$ se concentra na $12^{\underline{a}}$ Região Militar - "Região Mendonça Furtado". Este comando constitui um escalão avançado de planejamento, coordenação e controle dos diversos setores que o compõe, tendo em sua área de jurisdição unidades e subunidades isoladas, cujo apoio logístico demanda um tratamento especial por suas peculiaridades materiais e étnicas.

A $12^{\text {a }} \mathrm{RM}$ é uma área que recebe tratamento especial, pois enfrenta grandes desafios em termos de deslocamento, manutenção e logística das unidades de selva. $A$ essa Brigada cabe o desafio de atender às comunidades indígenas, algumas delas com pouco ou nenhum contato com o "mundo civilizado".

Como se percebe esse tipo de trabalho realizado pelas Forças Armadas é diferente do campo de formação militar. Considerando-se a necessidade de conhecimento mais profundo sobre esses grupos étnicos, de suas línguas e de suas culturas, restam dúvidas sobre como se dá efetivamente esse relacionamento.

Podemos observar que muitos soldados e cabos que servem ao Exército em Roraima têm ascendência indígena. Assim, muitos deles são "caboclos", segundo designação local, e mantém fortes laços culturais e étnicos com os grupos indígenas de

${ }^{130}$ Compreende os estados do Amazonas, Acre, Rondônia e Roraima. 
Roraima. A nosso ver, isso continua concretizando o processo de incorporação dos povos indígenas à "união nacional”, implantado desde o início da colonização brasileira.

O maior desafio enfrentado nessa relação de "fricção interétnica" tem-se dado na área do atendimento médico, uma vez que as Organizações Militares de Saúde (OMS), além de atender a militares, possuem também convênios com organizações civis de saúde, bem como com associações de profissionais autônomos. Desse modo, atende às comunidades civis e indígenas na fronteira, por intermédio do Sistema Único de Saúde.

Em hospitais de Guarnição, como o de São Gabriel da Cachoeira e Tabatinga, os atendimentos para o pessoal não-militar, onde estão incluídos índios, civis nacionais, civis e militares dos países vizinhos, chegam a representar mais de $90 \%$ do movimento global. ${ }^{131}$

Tendo em vista a inexistência de infra-estrutura para assistência à saúde nas áreas indígenas, tanto os hospitais militares quanto os hospitais da rede pública das cidades mais próximas acabam assumindo o atendimento médico-hospitalar dessas comunidades. As OMS que atuam na Amazônia Ocidental são: Hospital Geral de Manaus (HGeM); Hospital de Guarnição de Tabatinga (HGuTab); Hospital de Guarnição de São Gabriel da Cachoeira (HGuSGC); e Hospital de Guarnição de Porto Velho (HGuPVe); além do Posto Médico de Boa Vista.

É importante destacar essa ênfase e esse investimento do setor militar, notadamente da Marinha, na saúde na região amazônica. A Marinha dispõe de embarcações equipadas para atender aos principais problemas de saúde em áreas isoladas. Em muitas áreas, porém, é também crucial o papel da Aeronáutica, tanto pelo acesso, que só pode ser realizado por via aérea, quanto pelo caráter emergencial do atendimento. O CMA opera

em conjunto com a Marinha, por meio do Comando Naval da Amazônia Ocidental e do $4^{\circ}$ Distrito Naval, e com a Força Aérea, por intermédio do I e VII Comando Aéreo Regional. Com esses meios, o CMA pode projetar o poder militar em toda a área amazônica, em curtíssimo espaço de tempo, e sustentar o apoio logístico a grandes distâncias. ${ }^{132}$

A maioria dos convênios é feito com instituições da área de saúde, como as secretarias de saúde dos Estados atendidos; algumas organizações não governamentais; organizações religiosas, dentre outras instituições que atuam na área.

\footnotetext{
${ }^{131}$ Site do CMA, acesso em setembro/2004

${ }^{132}$ Site do CMA, acesso em setembro/2004
} 
Por meio de Operações Cívico Sociais (ACISO) e Operações de Assistência Hospitalar (ASSHOP), a Marinha Brasileira, realizou cerca de 80.000 atendimentos (320 comunidades). Vale lembrar que, na Amazônia, os Navios de Assistência-Hospitalar "Carlos Chagas", "Oswaldo Cruz" e "Doutor Montenegro" são conhecidos pelos ribeirinhos como "Navios da Esperança", por levarem apoio governamental àquelas comunidades. (Relatório do Ministério da Defesa, relativo ao PPA 2001/2003)

Outra atividade que merece atenção do CMA é a educação. Em todas as OM de fronteira funcionam escolas de ensino básico e, em algumas, até de ensino médio, além de centros profissionalizantes implementados em convênio com as Secretarias de Educação, ou mesmo totalmente mantidas pelas Organizações Militares.

Vale aqui ressaltar o caso de Tabatinga, onde o comandante do Comando de Fronteira Solimões/8o Batalhão de Infantaria de Selva, é o diretor da Unidade Educacional de Fronteira de Tabatinga, tendo, sob sua responsabilidade, um total de 10 escolas, 250 professores e 8.000 alunos. ${ }^{133}$

Além das atividades abordadas, o Exército presta os mais variados tipos de apoio às comunidades civis e indígenas que orbitam em torno dos quartéis, por meios de suas $O M$, que realizam o transporte de merenda escolar, hospedagem e alimentação de professores e apoio ao Programa Universidade Solidária.

Proporcionam, ainda, manutenção de internato para crianças pobres e direção de centros de treinamentos profissionalizantes. Participam de campanhas de imunização contra endemias da área, executam evacuação aeromédica, suprimento de gêneros alimentícios e instalação de meios de comunicação, inclusive antenas parabólicas com retransmissores. (Ibidem)

Aqui merece menção a atuação das esposas de militares, que atuam no apoio a comunidades isoladas, seja na alfabetização ou em outras tarefas como na culinária e no artesanato. Enfim, dependendo do grau de integração que conseguem estabelecer com essas comunidades, elas adquirem uma experiência intercultural que "levam para a vida toda". ${ }^{134}$

Quanto ao papel das Forças Armadas no setor de comunicações, cabe destacar o papel do Exército que, através de sua engenharia de construção, participa da abertura de estradas. Com essa ação, o Exército consegue alterar profundamente a feição e a função de antigas cidades ribeirinhas, na medida em que os fluxos foram redirecionados para as áreas adjacentes às rodovias, inauguradas a partir da década de setenta.

Os batalhões subordinados ao $2^{\circ}$ Grupamento de Engenharia de Construção participaram da construção da BR-174 (Manaus-Boa Vista) e da BR-364 (Cuiabá-Porto

\footnotetext{
${ }^{133}$ Website www.timbo.eb.br

${ }^{134}$ Conforme depoimento de algumas esposas que já residirem nos Pelotões Especiais de Fronteira. Entrevistas realizadas em Boa Vista e no PEF de Pacarima/RR, em 2005.
} 
Velho-RioBranco-Cruzeiro do Sul). Atualmente continuam participando de obras de construção e de conservação das rodovias na região amazônica.

Tendo em vista a ênfase de nossa pesquisa no estado de Roraima, destacamos a importância do 6ํㅡㄹ Batalhão de Engenharia de Construção, criado em 1967, em Manaus, para dar continuidade à BR 174.

Segundo o jornal Folha de Boa Vista ${ }^{135}$, os primeiros militares do $6^{\circ}$ BEC chegaram na cidade de Boa Vista em janeiro de 1969, quando foram recebidos com grande entusiasmo pelo população local, que vislumbrou a possibilidade concreta de sair do isolamento em relação ao País e ao resto do mundo.

O artigo assinado pelo Dr. Francisco de Assis Campos Saraiva - oficial da reserva do Exército - escrito em comemoração ao $31^{\circ}$ aniversário deste batalhão, relata a grande euforia provocada com a chegada dos militares em Boa Vista, que tinham a "missão de construir a BR-174 e a BR-401, rumo às fronteiras mais setentrionais do Brasil".

Segundo este artigo,

Roraima sorriu, agradecida, sentindo o alívio de não mais estar no isolacionismo, quando no dia 22/12/75, às $16 \mathrm{~h}$, na altura do $\mathrm{km} 362$ da BR-174, próximo da linha do equador, houve um encontro das duas frentes de serviço representadas pelo Destacamento Norte e Sul, que se irmanaram nos mesmos ideais e se abraçaram ardorosamente no roncar dos tratores e no estrondo da última grande árvore que tombava naquele momento esplêndido.

O 6ํㅡㄹ BEC havia, então, concluído o desmatamento do último trecho da BR-174, possibilitando a ligação entre Boa Vista e Manaus, numa rodovia de $776 \mathrm{~km}$ de extensão. Antes, porém, em 1973, houve a conclusão do trecho norte da BR-174 (Boa Vista/BV-8 fronteira Brasil/Venezuela), conexão geoestratégica e econômica de forte relevância entre os países que compõe a Amazônia.

A construção da BR-174 concretizou a ligação rodoviária numa área de impossibilidade de utilização das vias fluviais durante a época da estiagem, quando o rio Branco fica praticamente intrafegável pelas embarcações que, por muito tempo supriram os municípios roraimenses com gêneros de primeira necessidade, materiais e equipamentos de toda ordem, provenientes de Manaus.

135 “ Um gigante aguerido do extremo setentrião brasileiro.” FBV, 07 e 08 de agosto/1999. 
O Jornal "A Crítica" de 30/12/1975 também dá ênfase às realizações do 6 BEC $^{136}$ chamando a atenção para o fato de que até a construção da BR-174, Roraima tinha poucos elos com o contexto nacional. Oitenta e dois anos depois da primeira tentativa feita por Sebastião Diniz de ligar Manaus aos extremo norte do país, o $6^{\circ} \mathrm{BEC}$ - realiza um sonho quase secular de Roraima integrar-se ao contexto nacional, deixando de ser um quase entreposto dos países que fazem fronteira com o Brasil. ${ }^{137}$

Papel preponderante na estruturação do território amazônico também é desempenhado pela Aeronáutica ${ }^{138}$, que em 1935, iniciou sua atuação nessa área, através do Correio Aéreo Militar. E, durante as décadas posteriores, consolidou sua atuação na área de segurança, comunicações e infra-estrutura, em áreas de acentuada dependência do transporte aéreo.

Em 1935 o Correio Aéreo Militar iniciava suas operações na Amazônia, com a aeronave WACO CSO, com capacidade de transportar até cinco passageiros, foi possível chegar ate Belém e iniciar a construção de 17 campos de pouso no estado do Pará e Tocantins. ${ }^{139}$

Em Janeiro de 1941, o governo federal criou o Ministério da Aeronáutica e o Correio Aéreo Militar passou a se chamar Correio Aéreo Nacional (CAN), recentemente reeditado pelo Ministério da Defesa do governo Lula, em 2004. O CAN já realizou, desde sua criação, milhares de atendimentos médicos e odontológicos às populações ribeirinhas e de áreas isoladas que vivem na Amazônia brasileira.

No que se refere à aviação, investimentos na construção de aeródromos na Amazônia vêm sendo realizados desde meados da década de 1950. Em 1956, foi criada a Comissão de Aeroportos da Região Amazônica (COMARA), com a finalidade de ampliar o número de aeródromos na região, como também melhorar a qualidade dos já existentes.

Em dez anos a COMARA construiu 80 aeródromos e ao completar 40 anos de existência a COMARA já havia construído 134 aeródromos, recuperando 96 pistas de pouso e asfaltando dezenas delas."

\footnotetext{
${ }^{136}$ Deve-se esclarecer que houve participação majoritária de civis na construção da BR-174. Segundo depoimento do Cel. Paulo da Cruz Seabra (reserva do $6^{\circ} \mathrm{BEC}$ ) - engenheiro cartógrafo, e, à época capitão que comandou e elaborou projetos técnicos para a BR-174 - menos de 10\% do pessoal que trabalhou na estrada era militar. Em todo caso, a responsabilidade e o comando das ações ficaram a cargo do $6^{\circ} \mathrm{BEC}$.

${ }^{137}$ Jornal A Crítica. Manaus, 30/12/1975.

${ }^{138}$ A missão primordial da Aeronáutica na Amazônia é a de vigilância do espaço aéreo, reconhecimento, interceptação, e ataque, além de efetuar o controle aéreo, e atuar em operações aéreas especiais, em parceria com outros órgãos do Governo Brasileiro. Com a Polícia Federal atua no combate a vôos ilícitos.

${ }^{139}$ www.fab.mil.br, acesso em 05/2005

${ }^{140}$ www.fab.mil.br, acesso em 05/2005
} 
$\mathrm{Na}$ década de 60, foram criados esquadrões aéreos na Amazônia, que puderam operar graças às aeronaves adquiridas à época pela FAB, a exemplo do DHC-5 e do Buffalo (FOTO 1), capazes de operar em pistas precárias e sob as mais adversas condições meteorológicas.

\section{FOTO 1}

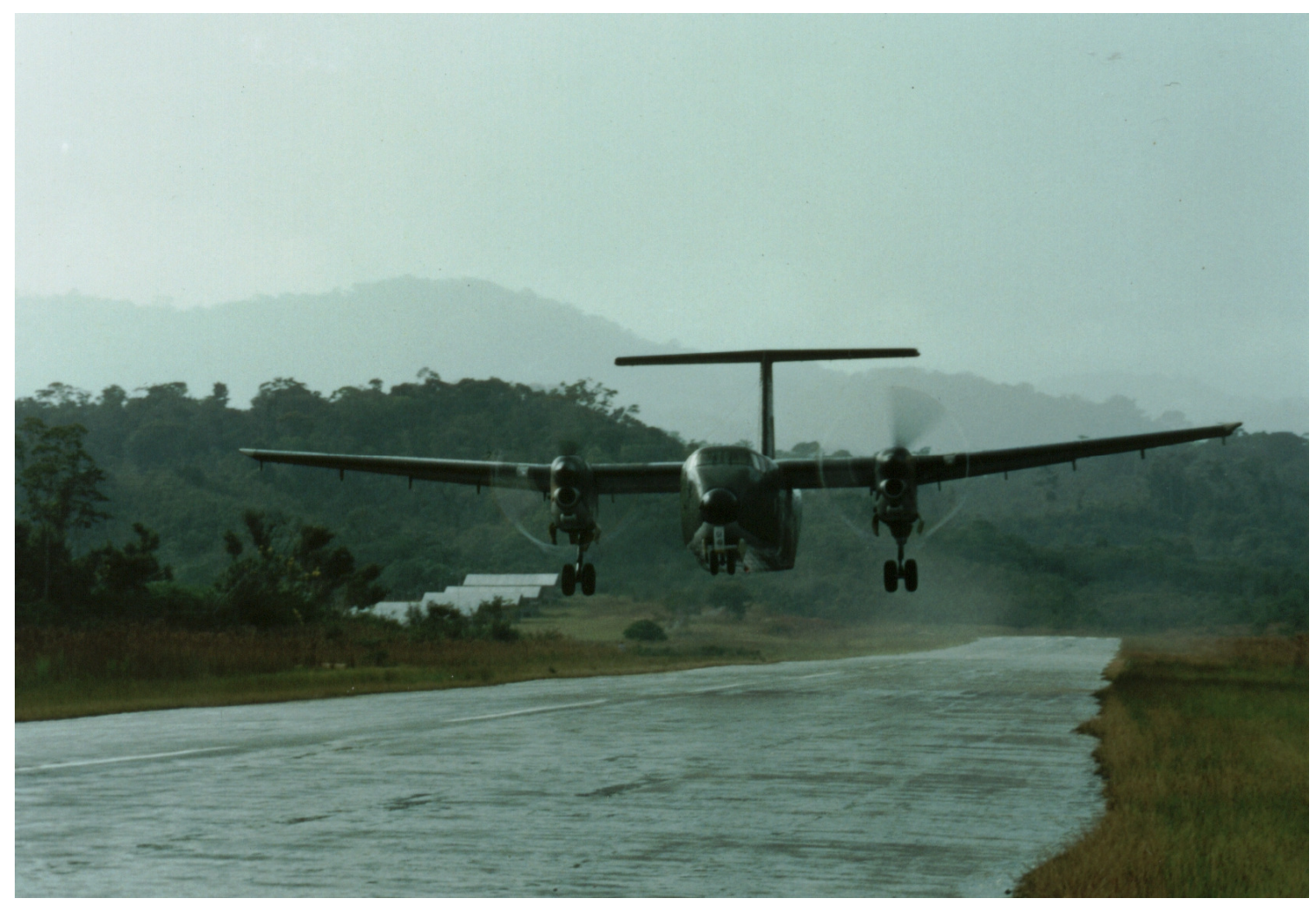

Aeronove Búfalo próxima ao PEF de Auaris

Com uma capacidade de carga impressionante para os padrões da época, o Buffalo foi utilizado não apenas para o transporte de pessoas, como também para transporte de cargas e máquinas, que possibilitaram a pavimentação e recuperação de estradas na região. Posteriormente, chegou o quadrimotor Lockheed Martin C-130 Hércules, com sua enorme capacidade de carga, transportando usinas de asfalto e quantidade suficiente de asfalto para pavimentar pistas em obras.

A partir de 1973, a FAB recebeu os bimotores EMB-110 Bandeirante, que em função da significativa ampliação e melhora da malha de aeródromos possibilitou uma maior capilaridade da FAB na Amazônia. Outros aviões também participaram deste intento como o Cessna 208 Caravan e o EMB-120 Brasília, mais tarde incorporados à $F A B$. 
Até recentemente, o atendimento aéreo na região amazônica era feito, sobretudo, pelas aeronaves C-130 Hércules, C-115 Búffalo, C-95 Bandeirantes, C-98 Caravan e Embraer C-97 Brasília.

O A-29 Super Tucano (FOTO 2) foi introduzido em 2004, para atuar na vigilância do espaço aéreo, sobretudo na região de fronteira, na aplicação da Lei do Tiro de Destruição, e como ferramenta para instrução dos novos pilotos de caça. Possui um sofisticado sistema de navegação que permite navegar sem informações externas e atacar com uma gama de munição, incluindo bombas, mísseis e metralhadoras. ${ }^{141}$

\section{FOTO 2}

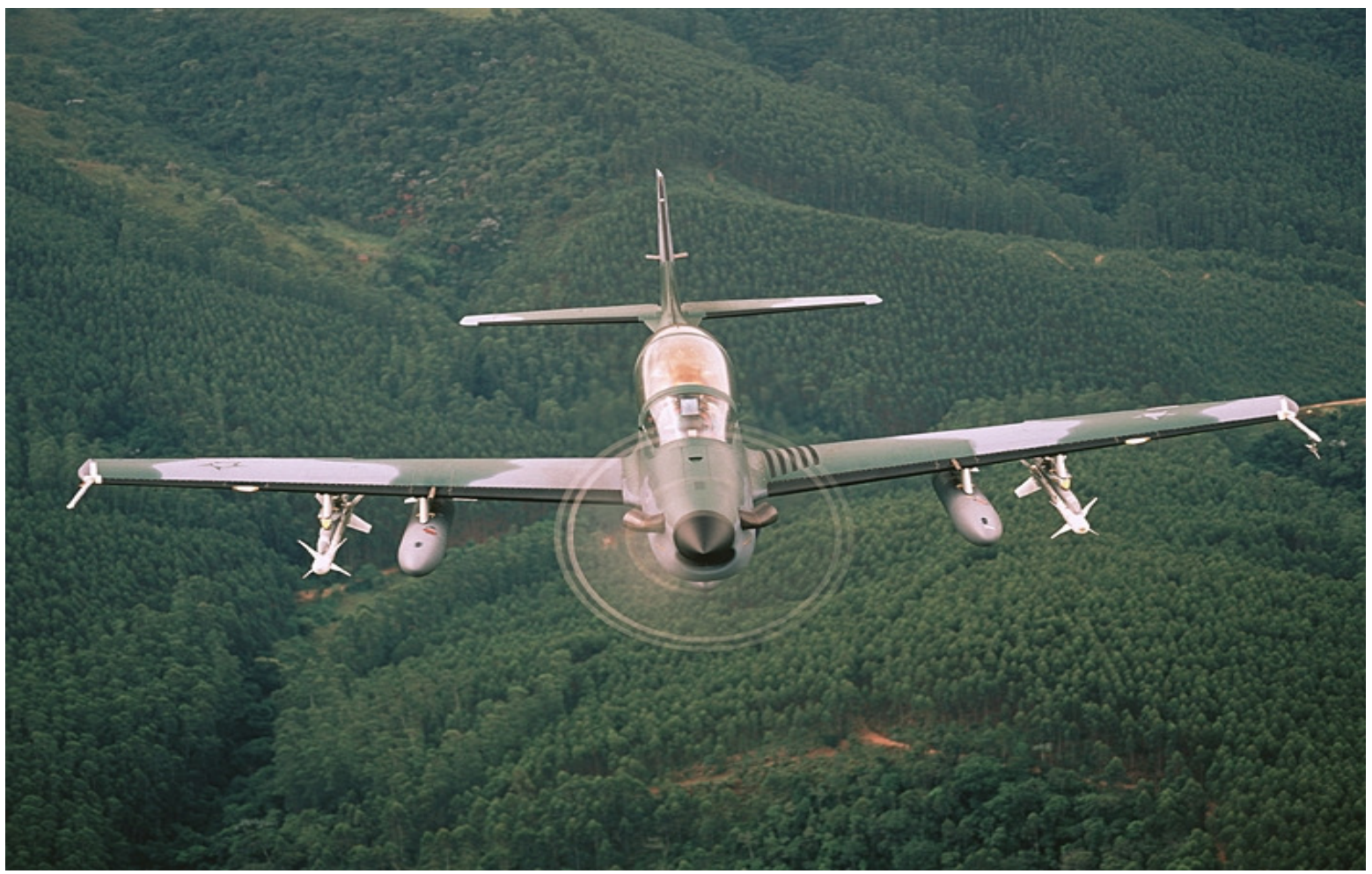

Fonte: CCSIVAM, Ministério da Defesa, 2006

Em 2006, através do Programa de Reaparelhamento da FAB, antigos modelos foram modernizados e novas aeronaves vieram incorporar-se às já existentes, como o helicóptero H-60 Black-Hawk, de fabricação norte-americana, com capacidade de transportar até quatro toneladas de carga externa, e o C-105 Amazonas. Eles vieram susbstituir os C-115 Buffalo.

${ }^{141}$ Aerovisão. Revista da FAB, n ${ }^{\circ} 217$. Out/Dez 2006. 
No ano de 2006, a FAB também recebeu as duas primeiras unidades do F-2000, o caça supersônico Mirage 2000-C, de fabricação francesa, com possibilidade de reabastecimento em vôo, radar digital de grande alcance, e economia de recursos de até $50 \%$ em relação ao antigo F-103 Mirage, que saiu de operação em 2005. Está prevista a aquisição de 99 aviões deste modelo para atender a todas as regiões do país. ${ }^{142}$

Atualmente existem cinco bases aéreas na Amazônia, subordinadas ao VII COMAR e I COMAR (Comando Aéreo Regional), sendo a mais nova a de São Gabriel da Cachoeira, ainda em fase de implantação. ${ }^{143}$

A sede do VII COMAR está localizada em Manaus e tem jurisdição sobre as bases aéreas de Manaus (criada em 1960); Boa Vista (criada em 1984), e Porto Velho. O I COMAR tem jurisdição apenas sobre a Base Aérea de Belém, originada do Correio Aéreo Militar, em 1936.

Quanto ao transporte fluvial, o CMA possui um centro de embarcações equipado com barcos pesados, navio-oficina, navio-hospital e outros tipos de barco adaptados às condições especiais de navegabilidade fluvial na Amazônia. A grande quantidade de rios navegáveis permite que a maior parte do transporte de materiais, equipamentos $\mathrm{e}$ alimentos seja feito através das aquavias.

A Marinha é responsável pela segurança e pela defesa na área marítima da Amazônia, que corresponde ao litoral do Pará, Amapá e parte do litoral maranhense. Mas também atua nas grandes vias fluviais do ocidente da Amazônia, estando mais presente em ações humanitárias, de saúde, de resgate e de apoio logístico, dentre outras atividades desenvolvidas em áreas ribeirinhas, de difícil acesso, em parceria com outros órgãos civis e militares.

Até aqui apontamos, o papel que os militares vêm exercendo, em parceria com várias instituições, em áreas sociais como saúde, educação, transporte e comunicação. Em relação ao último dos aspectos apontados, é importante destacar a instalação de pontos de internet em longínquos vilarejos e pelotões de fronteira, que se configuram como o meio mais eficaz de inclusão à modernidade, ainda distante dessas populações.

O que se observa é que a atuação mais recentes mantém, ainda que aparentemente, a mesma concepção de fixação de contingentes civis ao redor de

\footnotetext{
${ }^{142}$ Ibidem

${ }^{143}$ A partir de 1986, as zonas aéreas passaram a ser denominadas Comandos Aéreos Regionais (COMAR).
} 
Organizações Militares, que servem para criação de núcleos urbanos, gradualmente, integrados ao restante do País.

Não obstante, os resultados da nossa pesquisa têm revelado que há uma nova estratégia que se concretiza com a intensificação da presença militar em áreas isoladas. Afinal, nos dias de hoje, os militares já não são os únicos atores a atuar nesse cenário. Eles agora têm de atuar dentro de uma rede mais complexa e por isso já não têm o poder de decidir unilateralmente, como aconteceu durante décadas nos territórios federais. Há de se considera também que os núcleos urbanos cresceram e que outras instituições concorrem para assumir as atribuições do poder público.

Por outro lado, nas "unidades de selva" também se configura uma nova geopolítica de apropriação dos espaços. Atualmente não é mais foco de interesse dos estrategistas incorporar estas áreas ao capital, nem se contrapor às etnias, às culturas e aos demais elementos identitários dos "povos da floresta", da forma como foi feita em décadas passadas.

Nas próximas seções procuraremos mostrar, através do percurso dos militares no vale do Rio Branco, o modo pelo qual esta "espacialidade militar" foi construída e como essa construção mudou o cenário local; discutiremos, ainda, as expectativas em relação ao importante papel a ser desempenhado pelos militares no novo quadro que se desenha para o lugar. 


\section{IV.2 Estratégias de ocupação e modernização militar no vale do rio Branco}

A partir da primeira iniciativa de ocupação e defesa do vale do rio Branco, simbolizada pela construção do Forte de São Joaquim, no final do século XVIII, a presença de colonos nessa área passou a ser incentivada por meio de projetos de ocupação, levados adiante pelo engenheiro militar Manuel da Gama Lobo.

Ainda que de forma incipiente, o Cel. Lobo D'Almada, implantou alguns núcleos de colonização para o abastecimento de carne dos pequenos povoados de áreas adjacentes, que à época, tal como o vale do rio Branco, ainda faziam parte da Capitania do Grão Pará.

Ao compararmos a história do vale do rio Branco com a de outras áreas da Amazônia, que desde o século XVIII tinham uma economia estruturada e uma elite local, casos do Pará, Amazonas e Mato Grosso, notamos que o interesse geopolítico da União pela área do rio Branco não correspondia à implementação de estruturas capazes de reverter o quadro de isolamento em relação aos centros mais dinâmicos do País. Por mais de um século a paisagem do rio Branco era apenas composta por uma fortaleza e três fazendas de gado, além de aldeias indígenas dispersas e pouco integradas ao projeto civilizador que ocorria em outras áreas da Amazônia. (SANTOS, 2004:251)

Pode-se dizer que os projetos iniciais, desencadeados pela coroa portuguesa, no final do século XVIII, eram ainda iniciativas simbólicas de domínio territorial, num momento em que o interesse exploratório na região mal havia atingido o vale do rio Negro. Não obstante o papel político que o território do Rio Branco - posteriormente, chamado de Território Federal de Roraima, e, finalmente constituído em Estado da Federação brasileira, em 1991 - irá desempenhar, mais tarde, é de relevância significativa.

Mas isso deve ser compreendido à luz das políticas implantadas após a década de 1940, quando esta localidade assumiu importância estratégia a partir do primeiro "projeto de nação". Elaborado pelo centralismo do Estado brasileiro, o projeto foi concebido no contexto de políticas totalitárias implantadas em alguns países europeus e pelas quais o presidente Vargas mantinha clara simpatia ${ }^{144}$. Apesar disso se pode afirmar que um

\footnotetext{
${ }^{144}$ Sobre a Geopolítica deste período consultar MIYAMOTO, S. (1980); VESENTINI, J.W (1986); além das revistas: Defesa Nacional; Digesto Econômico, dentre outros. Uma análise das principais idéias de geopolíticos brasileiros foi realizada por COSTA, W. (1992).
} 
projeto de ocupação estratégica, propriamente dito, da área do vale do Rio Branco, só foi efetivado após a década de 1960, durante o regime militar.

A primeira iniciativa de valorização estratégica dessa fronteira encabeçada pelo setor militar iniciou-se em meados da década de 70, com a construção de vias de acesso nos principais vértices do Estado: as BRs 210; 401 e 174.

As três obras ficaram inconclusas do ponto de vista dos objetivos iniciais. A BR210, que devia atravessar a área Yanomami, foi embargada e não atingiu o objetivo de fazer a conexão com o noroeste do Amazonas e com as fronteiras da Venezuela e da Colômbia.

A BR-410 foi concluída até o limite com o rio Itacutu, que separa a cidade brasileira de Bonfim da cidade guianense de Lethen. A ponte de acesso a Lethen nunca foi concluída (apesar de as obras se encontrarem em estado avançado); do mesmo modo o acesso ao Porto de Georgetown, na capital da Guiana, que obterá recursos do governo brasileiro, depende de grandes investimentos e negociações, até hoje em andamento.

Como parte do Acordo para criação da Área de Livre Comércio, recentemente assinado pelo presidente Lula, o governo brasileiro se compromete a completar a ligação rodoviária até a capital Georgetown. O projeto ainda dependente de uma série de condicionantes, sobretudo na parte do licenciamento e de uma condução política mais coerente por parte dos governos envolvidos.

Já a BR-174, que liga Boa Vista à cidade de Santa Helena do Uairén, na Venezuela, foi concluída no final da década de 70 e pavimentada em 1997. É, atualmente, a mais importante via de acesso à Venezuela e ao Caribe. Apresenta, no entanto, um sério condicionante, uma vez que o município fronteiriço de Pacaraima localiza-se dentro da área indígena Raposa/Serra do Sol. Assim, praticamente todas as iniciativas de "vivificação" da fronteira - um dos jargões mais presentes do discurso militar - dependem do destino que se dará a essa área.

Por outro lado, a pavimentação do trecho Manaus/Boa Vista, em 1997 pode ser compreendida como um marco na efetiva integração de Roraima ao centro mais próximo, situado a aproximadamente $700 \mathrm{~km}$ da cidade de Manaus. A existência da estrada, aberta no final da década de 70 , não permitia um deslocamento efetivo, em vista das condições locais de alta pluviosidade que a tornavam intransitável. 
À primeira vista, quando analisamos a criação de unidades militares em outras áreas fronteiriças do território nacional, que foram concebidas conforme a idéia de "vivificação" da fronteira, parece estranho que o vale do Rio Branco tenha permanecido fora desse processo por tão longo tempo. O fato se torna compreensível quando se considera a ausência total de meios de comunicação que o conectasse aos circuitos produtivos já existentes no território nacional, o que só foi alcançado, com todos os condicionantes citados, em meados da década de 1970.

No entanto, o planejamento da ocupação na Amazônia é bem anterior. Em algumas localidades, o processo iniciou-se no final do século XIX, a partir de colônias militares. As colônias militares surgiram nesse período (1898) com a tarefa de facilitar a colonização do interior e guarnecer as longínquas fronteiras. Perduraram até 1913, recebendo foros de cidades. Ressurgiram com a criação das unidades de fronteira em 1930, com a mesma missão das antigas colônias" (Website do Exército).

Apesar de não ter atendido plenamente aos propósitos de ocupação e integração aos centros mais dinâmicos do território nacional, as grandes marcas deixadas no espaço geográfico de Roraima são provenientes do "Fausto" da colonização militar na fronteira, iniciada com o Contingente de Fronteira ${ }^{145}$, na década de 1940 , e intensificada no final dos anos 60. Para muitos que vivenciaram este momento, a vida deste Estado divide-se em antes e depois da transferência do $6^{\circ}$ BEC (1968) para Boa Vista, que em parceria com a Aeronáutica, mudaram totalmente a paisagem local.

Esse momento de ampla modernização do cotidiano local é uma página da história militar na região muito citada por militares da reserva, que vivenciaram diretamente a epopéia dessas realizações. Os depoimentos de civis e militares que testemunharam esse momento trazem à tona um aspecto praticamente sem estudo e com registros insatisfatórios, em relação aos jovens, em sua maioria do baixo escalão militar, que se aventuravam pela "selva", com pouca ou nenhuma recompensa, sob um comando, localizado a milhas de distância, e num período cujo lema era "integrar para não integrar.

\footnotetext{
${ }^{145}$ Documento do $7^{\circ}$ BIS/RR, informa que o Ministro da Guerra Pandiá Calógeras, no início do século XX, criou os "Destacamentos Militares de Fronteira", com recrutamento a partir dos "Batalhões de Caçadores". E, nessa época, em 1920, esses destacamentos foram denominados por "Contingentes Especiais de Fronteira". (Mimeo, s/d) Embora não se registre para o vale do rio Branco, nenhuma estrutura mais sólida desta época, e que tenha permanecido nas décadas posteriores. As referências históricas sobre o vale do rio Branco, somente nos permite dizer, por ora, que existiram unidades precárias e intermitentes nessa área, sem testemunhos concretos na paisagem atual.
} 
Sou da opinião de que os registros elaborados pelas ciências sociais não dão conta da especificidade desse momento. ${ }^{146}$

Foge ao âmbito desta pesquisa uma análise mais aprofundada da experiência obtida por esses militares, ao longo de algumas décadas de implantação dos núcleos colonizadores, e que contribuíram, em grande escala, para a formação da territorialidade hoje existente. Uma pesquisa dessa natureza certamente teria como pressuposto uma base metodológica diferenciada da que adotamos nesse trabalho, pelo caráter desta investigação e pelo tipo de fonte mais freqüente neste caso, que são os registros orais.

Nas próximas seções, procuraremos demonstrar, de modo sucinto, como se deu a instalação e a permanência de unidades militares em Roraima, e o contexto de inserção deste Estado em políticas mais amplas.

\footnotetext{
${ }^{146}$ A pouca comunicação entre o setor militar e a academia tem sido abordada em estudos mais recentes por vários autores. As dificuldades ainda são grandes no sentido de levantamentos e consultas a documentos e até mesmo para se conseguir depoimentos das experiências vividas por atores militares. A importância da comunicação entre este setor e a sociedade é abordada, de forma mais ampla, por OLIVEIRA, E.R. (2005).
} 


\section{IV.3 A Colonização militar na ultima fronteira}

O primeiro núcleo militar permanente do vale do Rio Branco foi constituído em 1943, com a criação do $1^{\circ}$ Pelotão de Fronteira, que se originou do "Contingente do Rio Branco". A data coincide com o ano da transformação dessa área em Território Federal, quando o vale do Rio Branco foi desmembrado do Estado do Amazonas.

Pelo que se conseguiu apreender, o "Contingente" não tinha ainda um status que Ihe permitisse atuar localmente, pois não tinha nenhuma autonomia na implantação de políticas locais, que foram assumidas após a criação dos territórios federais, pelos pelotões. Tanto em número de efetivos quanto em grau de responsabilidade e mesmo em relação à infra-estrutura disponível e à permanência no local, as diferenças entre ambos são significativas.

Com a criação dos territórios federais, as áreas fronteiriças começaram a receber mais atenção da União. Isso fazia parte de um contexto mais amplo em que as preocupações com a unidade nacional serviram de base para a concepção do Conselho de Segurança Nacional.

Neste sentido, a criação de três Territórios Federais, nas áreas mais setentrionais do País, quais sejam: vale do Rio Branco, Território do Guaporé e Território do Amapá ${ }^{147}$, levados a efeito através do Lei 5.812, de 13/09/1943, fecham um ciclo de debates que já vinha sendo travado pela elite nacionalista durante algumas décadas.

Somente no ano de 1952 é que o primeiro pelotão assumiu um novo status e passou a ser designado de $1^{\circ}$ Grupamento de Elemento de Fronteira (GEF), com um destacamento no município de Bonfim, na fronteira com a Guiana ${ }^{148}$. A partir deste momento, as atribuições dos militares tornaram-se mais claras e abrangentes e passaram a se afinar com o compasso da administração do Território, uma vez que também passaram a ser comandadas pelos governadores militares indicados, a maioria deles, do quadro da Aeronáutica.

Os quadros administrativos para os territórios eram indicados pelos governadores, todos pertencentes à carreira militar; estes, por sua vez, eram indicados pelo governo federal. Para o Território Federal do Rio Branco, vieram os oficiais da Aeronáutica,

\footnotetext{
${ }^{147}$ Observe-se que o Território do Acre fora constituído desde 1904 pela situação peculiar de litígios fronteiriços com a Bolívia, no auge do ciclo da Borracha.

${ }^{148}$ À época ainda vinculada à Inglaterra.
} 
enquanto para o Território do Guaporé foram destacados oficiais do Exército e, para o Território do Amapá, oficiais da Marinha. Essa divisão se deu, certamente, em função das vias internas de acesso mais facilitadas para cada uma das forças por ar, terra e mar, respectivamente.

À época da criação do Território Federal do Rio Branco, a população total da região era estimada em 19.709 habitantes, sendo que os indígenas representavam mais de 70\% da população, segundo SANTILLI (1994:36). Entre as décadas de 1940 e 1950, quando foi realizado o primeiro censo do IBGE, a população branca do Território do Rio Branco praticamente dobrou, passando de 10.509 para 18.116 habitantes.

Nessa mesma época, o $1^{\circ}$ Grupamento de Elementos de Fronteira (GEF), criado em 1952, a partir do diminuto contingente de fronteira, atingiu o percentual aproximado de sessenta homens. Comparativamente ao número de habitantes, a presença dos militares ainda não se constituía nesse momento um fenômeno de destaque, capaz de alterar o quadro sócio-econômico do TF do Rio Branco. O que se pode afirmar é que a influência do poder central se fazia presença na vida do Território através de uma elite reduzida, com poderes de decisão.

Até o ano de 1961, o 1ํㅡrupamento de Elementos de Fronteira/GEF, ainda estava subordinado ao Comando de Belém. A partir desta data, será parte da 9a Companhia de Fronteira, sediada em Manaus. As reestruturações que se dão a partir deste momento preparam o caminho para o surgimento do Comando Militar da Amazônia/CMA, como visto, anteriormente.

Esta série de datas e eventos é reveladora das transformações internas que se operaram na estrutura militar, cujo dinamismo nos remete a conjunturas políticas e econômica vigentes, delineadas bem distantes desse Território. Mas este dinamismo não pode ser captado a partir dos dados contidos nos documentos que tivemos a oportunidade de consultar nos setores militares visitados. Mesmo uma rápida olhada nos websites das Forças Armadas, já nos permite concluir que, por meio dos materiais disponíveis, nada ou quase nada se revela sobre os motivos que levaram às freqüentes reestruturações e aos contínuos deslocamentos de tropas para a região.

Esse fluxo contínuo de transferências de contingentes para a região contrasta, todavia, com a curta permanência dos efetivos militares nas unidades para as quais são transferidos. Isso impossibilita o estabelecimento de um intercâmbio mais duradouro com 
a sociedade local, uma vez que as relações são construídas ao longo do tempo e com atores que possam dar continuidade aos projetos que iniciaram.

Assim, não se tem, localmente, um "memorial" dos acontecimentos que se processaram ao longo da existência dos territórios e mesmo após a década de 90 . Sendo poucos os militares que permaneceram em Roraima, após a atuação no serviço militar, e menos ainda o número de militares que presta serviço no Estado por mais de cinco anos (no geral nunca extrapolam o prazo de dois anos), a possibilidade de apreender esse momento a partir de seus protagonistas se torna extremamente reduzida. ${ }^{149}$

Durante visita aos PEFs de Pacaraima e Bonfim, consultamos alguns registros dos eventos cotidianos destas unidades, relativos ao período em questão. Os vários relatos contém pouca conexão com os eventos de defesa e segurança dos pelotões. Em geral tratam de fatos corriqueiros como a chegada do Buffalo, que representava ${ }^{150}$ um fator importante para o abastecimento do pelotão.

Também há vários registros sobre a chegada e despedidas dos comandantes; sobre as comemorações ligadas ao setor militar e sobre as visitas de autoridades brasileiras e dos países vizinhos. Além disso, há registro que fazem menção a comemorações e exercícios conjuntos com militares venezuelanos, no caso do PEF de Pacaraima, bem como às ações cívicas realizadas junto às comunidades nas quais os PEFs se encontram. ${ }^{151}$

Sobre segurança e defesa, encontramos apenas o registro: a "entrega" de trinta e dois garimpeiros presos pelo Exército venezuelano, em março de 1994. Digno de nota é um chamado curioso relativo a "Instruções sobre reconhecimento do regime democrático" (direitos e deveres, em 05/03/1992).

Do mundo externo, ficaram registrados: a preocupação com a instabilidade política da Venezuela; a "conquista do Monte Roraima" - o ponto mais extremo do Brasil (altitude

\footnotetext{
${ }^{149}$ Consta na "Galeria dos Comandantes", da 1 a Brig. Inf. Selva de Roraima, um total de vinte e dois generais, do período de Fevereiro de 1969 a agosto de 2005. De lá para cá, mais dois generais fazem parte desta galeria. Já na galeira de coronéis e tenentes coronéis do $7^{\circ}$ BIS, o número reduz-se a 17 comandantes, no mesmo período. Segundo o Cel. Seabra, os oficiais mais graduados permaneciam em Roraima um ano, subtenentes e sargentos, até um ano e meio.

150 Os "Búfalos" ainda atendem aos PEFs, mas já estão sendo substituídos por aeronaves mais modernas.

${ }^{151}$ Uma vez que a hierarquia militar está presente em todas as dimensões da "vida da caserna", todos os relatórios são enviados diretamente aos altos comandos do Exército. Por isso, cremos que deva existir um bom material para consulta nos arquivos centrais desta instituição, fato que não pudemos comprovar devido aos limites desta pesquisa.
} 
$2.856 \mathrm{~m}$ ), em 07/12/92, e curiosamente o acidente que vitimou o piloto brasileiro Airton Sena, em 01/04/1994.

Dado que os relatos se atêm aos eventos sociais do Batalhão e não estabelecem qualquer relação com as funções que supostamente sustentavam a presença do Exército nessa fronteira, podemos concluir que a unidade desse comando era sediada a milhas de distância, de onde eram tomadas todas as decisões a serem cumpridas localmente.

Aconteceu assim em 1969, quando Roraima adquiriu um novo status estratégico do ponto de vista militar, com a instalação de um comando próprio, denominado Comando de Fronteira de Roraima - CFR, composto pelo $7^{\circ}$ Batalhão de Infantaria de Selva - $7^{\circ}$ BIS (Foto abaixo). Esta foi a base para a posterior ampliação das unidades militares hoje existentes no Estado de Roraima.



7ª BRIGADA DE INFANTARIA DE SELVA/RR $-7^{\circ}$ BIS 
Com relação ao impacto local dessas medidas, os depoimentos colhidos foram muito vagos ${ }^{152}$. Em geral, a população local sempre esteve alienada de todos os "atos do governo". Sabia-se que estava acontecendo alguma coisa, mas não se sabia exatamente o quê. Tropas de Manaus e de Belém começaram a aparecer, a cidade foi fechada e a população pôde sentir que estava no centro de um conflito. ${ }^{153}$

Sob o ponto de vista estratégico, a posição do Estado de Roraima é decisiva em termos de potenciais conflitos de âmbito regional. O exemplo mais ilustrativo é o da área litigiosa entre a Venezuela e Guiana, na Região do Essequibo, onde no início da década de 60 a Venezuela solicitou duas vezes a utilização do território brasileiro (BV8 - Surumú - Contão - Normandia) para passagem de tropas blindadas. Este pedido visava a invasão da referida área da Guiana, tendo na época a negativa do Governo Brasileiro. (Revista Veja 12/4/1963) ${ }^{154}$

Assim, se pode concluir que, desde a fundação do Forte de São Joaquim, ou seja, durante praticamente dois séculos, não houve preocupação em estabelecer na área do "Rio Branco" uma estrutura militar completa. O fato de ter ocorrido somente no final da década de 60, nos leva a crer que, realmente, o governo brasileiro passou a considerar a área fronteiriça como área suscetível, num cenário de conflitos regionais. Por isso foram criados, em janeiro de 1969, três pelotões na fronteira com a Guiana: Pelotões de Bonfim, Normandia e Surumu.

Com a abertura da BR-174 e a conclusão da ligação Boa Vista-BV/8, no marco Brasil/Venezuela, em março de 1973, o destacamento de Surumu mudou-se para essa localidade de fronteira, atual município de Pacaraima. Os destacamentos de Normandia e Surumu somente tiveram suas instalações prontas, em março de 1972. (Vide Figura 7)

Esse momento foi de grande dinamismo no setor da construção civil. $O$ 6o Batalhão de Engenharia de Construção/BEC, que já estava instalado desde 1968, superou limites com a construção de muitas obras, num Território ainda destituído de

\footnotetext{
${ }^{152}$ Estes depoimentos não foram formalizados, através de questionários, pois ainda se tratava de uma primeira "aproximação objetual". Deve ser destacado que a "explosão demográfica" em Roraima ocorreu somente no final da década de 80, por ocasião dos garimpos, portanto, a população mais antiga é bem menos expressiva, além disso, muitos funcionários públicos que vieram para Roraima, à época do Território Federal, posteriormente, foram transferidos, não apenas os militares.

${ }^{153}$ Depoimentos colhidos com o Sr. Antônio, garimpeiro, vivendo atualmente em Manaus. Este mesmo ator afirmou também que à época a Praça dos Três Poderes (Foto 1 - círculo que se observa no final da Êne Garcez) era conhecida como "Praça dos Três Patetas", em referência às três forças militares: Exército, Marinha e Aeronáutica e não como referência ao Executivo, Legislativo e Judiciário, como de costume.

${ }^{154}$ Vide AGOSTINHO, J. (2000:50)
} 
obras arquitetônicas relevantes. ${ }^{155}$ Roraima era, até então, um ponto remoto e totalmente isolado do resto do País, como afirma o trecho abaixo:

Até então levava-se sessenta dias de barco de Manaus para Boa Vista, na época da cheia. E, de Boa Vista para Normandia (Mau) mais quinze dias. As crianças recebiam nome do "santo da época" através do padre, e quase tudo o que não se encontrava no mercado local (bicicletas, máquinas de costura, utensílios em geral) vinha da Inglaterra, através de trocas realizadas com os fazendeiros guianenses. ${ }^{156}$

155 A igreja Nossa Senhora do Carmo e a Intendência, provavelmente, eram os únicos prédios que se destacavam na paisagem, até a década de 70 .

${ }^{156}$ Depoimento do Cap. Damásio, em março de 2006. 


\section{IV.4 O "Fausto Militar" em Roraima}

Como já afirmamos, a vinda do 6ํㅡㄹ $\mathrm{BEC}$ foi um evento marcante para a história local e para a paisagem do lugar. Os militares que chegaram ficaram acampados em barracas de lonas, no bairro Mecejana. A nosso ver, isso é reflexo de que a decisão de transferir esse contingente foi tomada às pressas, no afã de se chegar rapidamente à fronteira mais isolada do País, e que era, então, de importância central no cenário geopolítico acima descrito. A principal missão era a construção das BRs-174 e 401.

Os primeiros militares que deram vida ao $6^{\circ}$ BEC chegaram a Boa Vista no dia 15 de janeiro de 1969 e se instalaram, provisoriamente, em barracas de lona armadas no bairro do Mecejana, onde hoje, é a sede do GRESSBE. Enfrentaram dificuldades de toda sorte e muito desconforto, mas a senda do dever estava arraigada no coração, na mente, e na alma daqueles brasileiros pioneiros. ${ }^{157}$

Inicia-se, assim, a construção dos prédios institucionais na mais bela passarela da cidade: a "Ene Garcez" - uma avenida de aproximadamente três quilômetros, que se estende do Aeroporto ao Palácio do Governo, sede do poder do Estado, para onde convergem as principais avenidas de Boa Vista, conforme foto a seguir.

FOTO 4

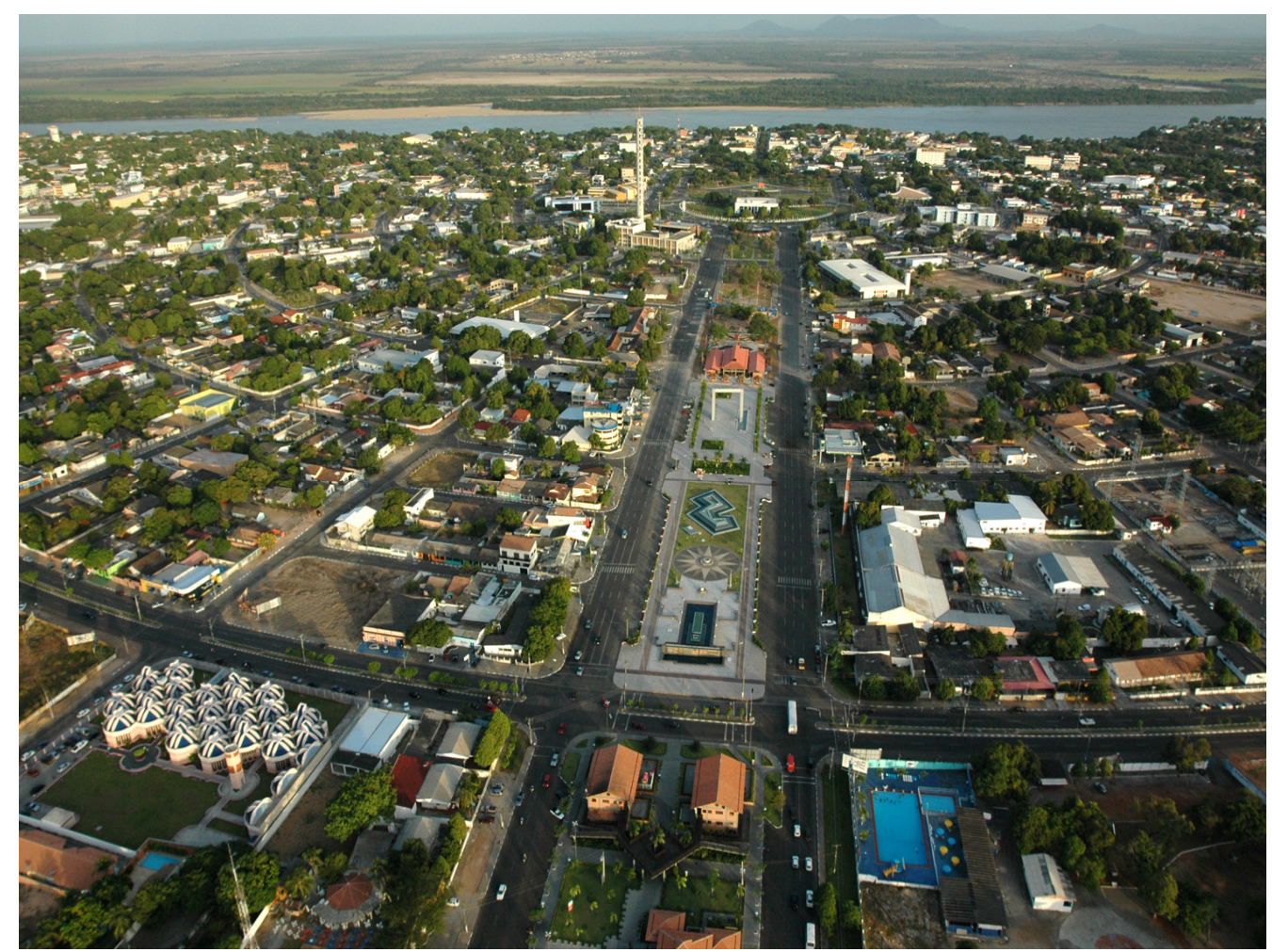

Foto cedida pelo autor: Sg. Lewinsk

\footnotetext{
${ }^{157}$ Folha de Boa Vista, 07 e 08 de agosto de 1999.
} 
Uma rápida olhada neste ângulo radial do desenho da cidade já se percebe a presença e a força do "ethos militar"158 que deu a tônica aos principais eventos que marcam a vida da cidade.

A avenida Ene Garcez chama a atenção de todos que chegam à cidade, pois foi desenhada como um canteiro central formado por belas praças, espaços de lazer para a prática de esportes e vários outros usos. Trata-se de uma área de encontro e de convivência extremamente agradável: pela manhã (bem cedo) ou após às 17:00h, a temperatura local permite que "se curta" este espaço, que aliás só tem os estabelecimentos abertos após às 17:00h.

Ao lado desse cenário, impecavelmente cuidado, bem arborizado, que serve ao descanso, ao esporte, ao lazer e ao encontro, de modo geral, percebe-se, dos dois lados da avenida, os amplos espaços destinados ao uso institucional. Tudo é horizontalmente organizado, impecavelmente limpo e marcadamente ocupado pelo setor militar e, secundariamente, pelas principais representações do poder local.

Em contigüidade ao Aeroporto, encontram-se a Base Aérea, a entrada da Universidade Federal de Roraima, a sede do clube da AABB ${ }^{159}$, o "Totozão"160, o cinema, o clube da Polícia Militar, a Delegacia de Polícia, o monumental ${ }^{161}$ prédio do $6^{\circ} \mathrm{BEC}$, o moderníssimo prédio da Boa Vista Energia ${ }^{162}$. (FOTOS 5 e 6)

\footnotetext{
${ }^{158} \mathrm{O}$ traçado impecavelmente retilínio das ruas; as avenidas largas propícias às paradas militares; a convergência para um único centro; despertam o sentido da ordem, da disciplina, da hierarquia, dentre outros aspectos que lembram a "essencialidade", a "especificidade" do ser militar.

${ }_{159}$ Associação Atlética Banco do Brasil, o banco oficial da cidade - "interditado" nos dias de pagamento, para quem não se dispõe a aguardar "horas" na fila, ou para realizar verdadeira via sacra, em busca de um caixa eletrônico que funcione plenamente na ocasião de pagamento dos funcionários públicos.

${ }^{160}$ Em homenagem ao governador Brigadeiro Otomar de Souza Pinto, segundo fontes orais, "Totó", para os íntimos.

${ }^{161}$ Monumental pela disposição de sua arquitetura.

${ }^{162}$ Com um belo e moderno prédio, o atendimento aos usuários, porém, estava sendo feito num canto afastado de toda beleza e eficiência que o prédio da Ene Garcez "promete". (Utilização dos serviços, em fevereiro/2007).
} 
FOTO 5

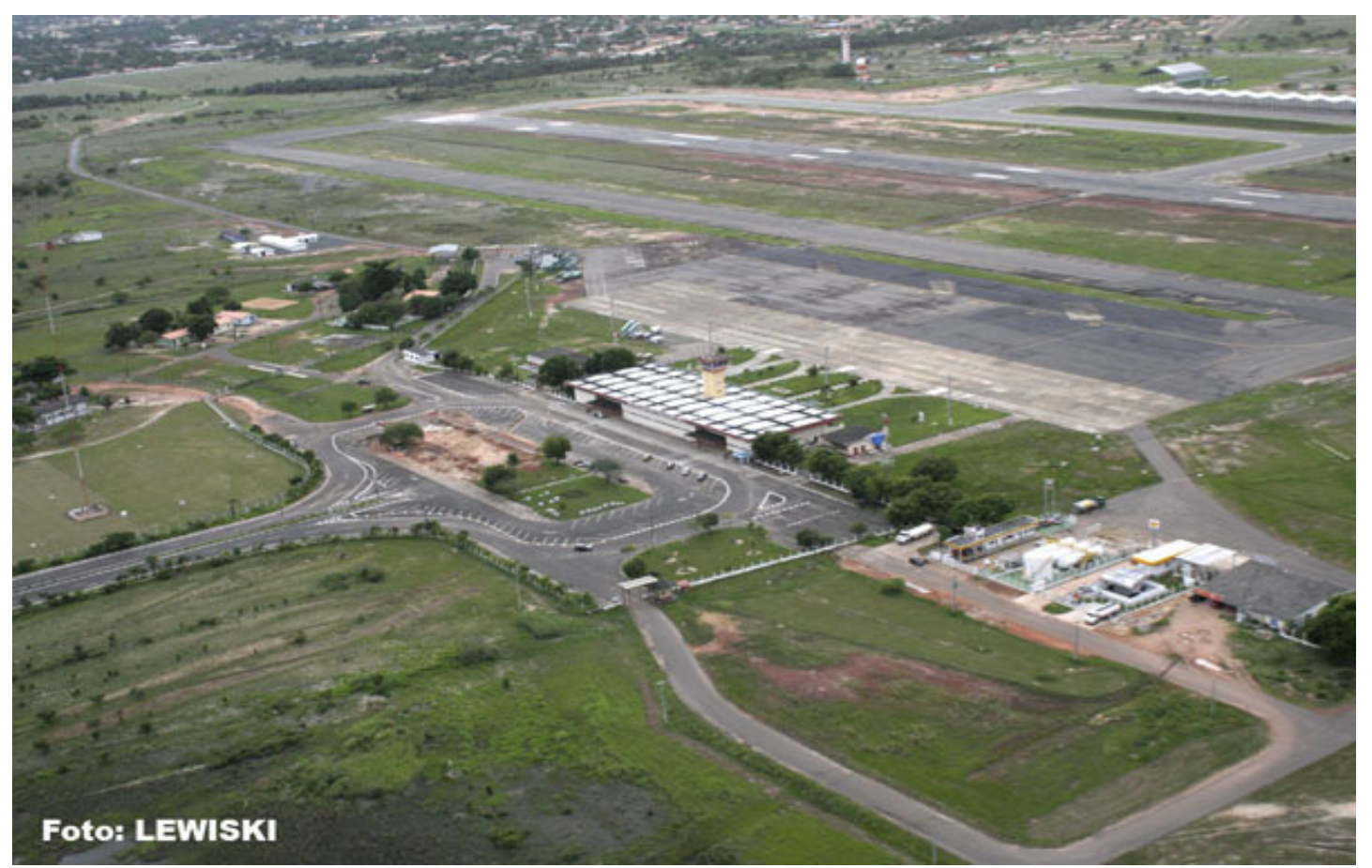

Aeroporto Internacional de Boa Vista

FOTO 6

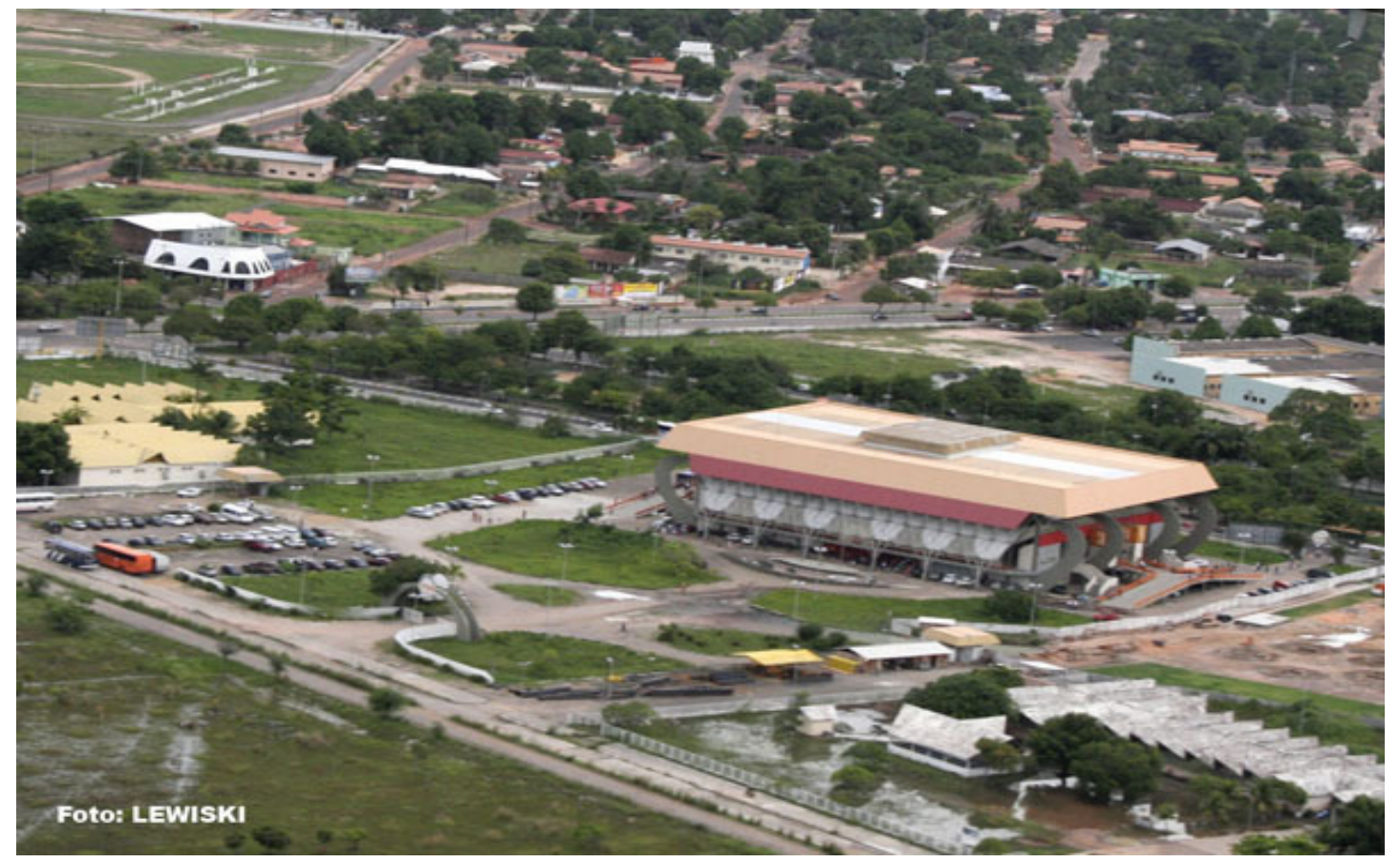

Ginásio de Esportes "Totozão"

Autor: Lewisk 
Do lado direito da Avenida, destaca-se a arquitetura modernista de primeira leva do prédio da Funasa; o Hotel mais recente e moderno da cidade (Norte Shopping Hotel) ${ }^{163}$; o Círculo dos Oficiais de BV (COB); o Hotel Militar; e as belas residências militares ${ }^{164}$.

\section{FOTO 7}

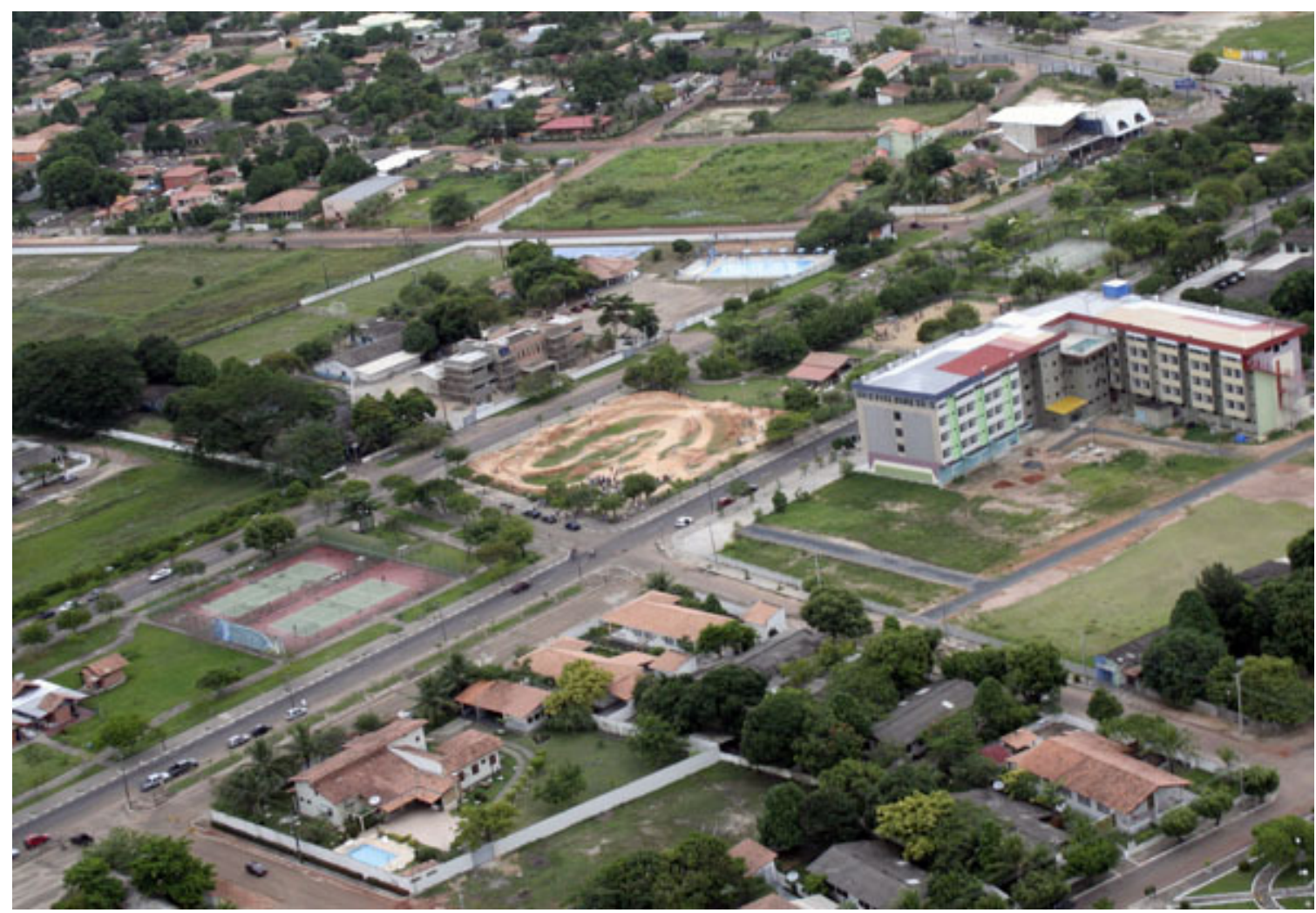

Norte Shopping Hotel e residências militares Autor: Lewisk

Além deste núcleo do poder instalado no trecho mais monumental da Ene Garcez, após a intersecção com a Avenida Major Willians, até o palácio do governo, situado no

\footnotetext{
${ }^{163}$ Inaugurado em 2006, com uma estrutura instalada para o comércio, embora as lojas ainda não tenham chegado (apenas uma ou outra já começa a se instalar).

${ }^{164}$ As "belas residências" são aquelas que ficam na e/ou mais próximas à Ene Garcez, outras residências que compõe esta Vila Militar, nas áreas adjacentes, são mais simples. A hierarquia militar é percebida também nos tipos de residência militar existentes, bem como nas distâncias em relação a esse "pólo de poder", uma vez que, em outros bairros, existem outras vilas militares, ou pequenos núcleos de casas destinadas a residência militar, habitada por oficiais de patentes menores. Os "sem patente", desafortunadamente, não dispõem de residência militar.
} 
círculo central, para onde convergem as principais ruas de Boa Vista, a avenida é marcada pelos estabelecimentos de comércio e por vários outros prédios institucionais.

Os recursos destinados à criação e à ampliação dessa infra-estrutura chegaram ao TF do Rio Branco graças aos planos governamentais que foram se sucedendo durante o regime militar: I PND; II PND, e, também, por força da nascente elite local, capaz de pressionar o poder central para o envio de verbas. Essa é basicamente a única fonte de recurso existente durante a época em questão. ${ }^{165}$

No mesmo artigo publicado pela Folha de Boa Vista, assinado pelo Dr. Francisco de Assis Campos Saraiva, oficial da reserva do Exército, um rol de obras, realizadas sob impulso do 6º BEC, são destacadas, enquanto materialização dos PNDs em Roraima:

(...)Construção de rodovias, prédios, vilas, casas, estradas, obras de saneamento, asfaltamento de estradas, ruas e avenidas e um sem número de outras edificações." O autor afirma que a presença do $6^{\circ}$ BEC também foi marcante em todos os setores de atividades, tanto nas tarefas precípuas, como nas obras de cooperação com o Governo do Estado, Prefeitura Municipal e Órgãos Públicos, no apoio à comunidade local, assistência ao trabalhador rural (...) (FBV, 073 08/08/1999)

A criação do 6o BEC $^{166}$, juntamente com a do Comando de Fronteira de Roraima/CFR ${ }^{167}$ e do primeiro Batalhão Especial de Fronteira, ocorrida em maio de 1969, (designado $2^{\circ} \mathrm{BEF}$ ), marcaram uma nova etapa no cotidiano de Boa Vista, que na condição de cidade primaz ${ }^{168}$, concentra, até hoje, quase todo o dinamismo de Roraima.

Embora se reconheça a atuação do 6을 $\mathrm{BEC}$ em todos os eventos acima apontados, a participação da Força Aérea Brasileira/FAB foi decisiva, sendo impossível atribuir a um ou a outro, isoladamente, o mérito das obras que foram realizadas em Roraima. Nos pelotões mais distantes, há um ditado que afirma que da primeira tábua ao último prego tudo foi transportado pelas asas da aviação.

\footnotetext{
${ }^{165}$ É abundante a literatura relativa aos programas de governo criados durante os anos 1960 e 70 . Baseamonos nas publicações de BECKER, B.; DINIZ, A.(1997); SANTOS, N.P.D. (2004), além dos relatórios e outros documentos relativos às políticas públicas implantadas na Amazônia.

${ }^{166}$ O $6^{\circ}$ BEC foi criado por força do Decreto Presidencial 63.184, de 27/08/1968

167 Baseamo-nos, nesta seção, mais na percepção da população sobre as OMs que contribuíram para a transformação da paisagem urbana, sem nos determos naquela parcela de militares mais diretamente relacionada às atividades de segurança e defesa, que também deixaram suas marcas e participaram da vida do TF do Rio Branco. Deve-se mencionar que, na década de 70, quase 3\% da população era composta por militares do Exército. Assim, quando falamos do "ethos militar" temos que nos referir aos militares como um todo, de todas as armas e categorias, inclusive aqueles, não vinculados à União. Quando se inclui todos estes setores é que se percebe com mais nitidez a participação da figura do militar em Roraima.

${ }^{168}$ Sobre a classificação dos núcleos urbanos de Roraima, vide SILVA, P.R.F. (2007)
} 


\section{IV.5 A criação de unidades militares num novo contexto democrático}

O contexto de criação do 4ํㅜㄹotõo Especial de Fronteira (PEF de Surucucu), em 1988, é de forte incentivo à migração para o Estado. O garimpo, a colonização agrícola, a possibilidade de explorar outros recursos como a madeira, além do forte apelo do governo Brigadeiro Ottomar (que permanece no comando do Estado até os dias atuais) à vinda de migrantes para Roraima, são os elementos de caráter sócio-econômico que se agregam ao fator político e geoestratégico de ampliação de unidades militares em Roraima. ${ }^{169}$

Nesta mesma década, foram criados seis novos municípios, todos dependentes de repasses da União. Na verdade não havia uma base econômica no Estado capaz de sustentar a grande massa de migrantes atraída nesse momento. As medidas de cunho populista que serviam para arregimentar eleitores, em sua maioria migrantes nordestinos (em especial do Maranhão), basicamente se esgotavam na entrega de lotes de terra, normalmente abandonados pelos colonos após curto período de tempo ${ }^{170}$.

Também a crise econômica vivenciada pelo País neste período desencadeou a falência dos grandes projetos nacionais, acarretando dificuldades nas áreas desprovidas de infra-estrutura básica. Neste sentido, a explosão de novos municípios na Amazônia serviu como importante mecanismo de captação de recursos, via Fundo de Participação dos Muncípios (FPM). ${ }^{171}$

SANTOS destaca as contradições do "modelo nacional" (PNDs) em relação aos projetos de cunho local que se estabeleceram a partir do governo Ottomar. A década de 80 é, assim, marcada, em Roraima, por iniciativas de autonomia em relação aos planejamentos homogêneos, feitos a partir da década de 60 para a Amazônia.

O autor mostra que entre os anos 1974/79 o governo Ramos Pereira queria implantar um modelo empresarial de capital intensivo através do POLAMAZONIA com os pólos agro-mineral e agropecuário e, ao mesmo tempo, impedir a migração espontânea $e$ familiar para os eixos das rodovias BR-174 e BR 210. Pereira não obteve sucesso em

\footnotetext{
${ }^{169}$ A TABELA 8 mostra que a população passou de 79.159, na década de 1980, para 217.583, em 1991, tendo o garimpo participado com maior número de imigrantes para o Estado.

170 Sobre a colonização agrícola consultar DINIZ (1998); FURLEY (1994); BARROS (1996); MOURÃO (2003); FREITAS (1993).

${ }^{171}$ O FPM é constituído de 22,5\% da arrecadação do Imposto de Renda e 22,5\% do Imposto sobre Produtos Industrializados/IPT, com rateios diferenciados, em função da categoria do município e do número de população. Também há outros repasses para os municípios, o que permite que muitos municípios amazônicos vivam deste expediente. Vide FIGUEIREDO, A.(1998)
} 
nenhuma dessas iniciativas, além de atritar com grande parte da liderança política local' (SANTOS, 2004:185)

No final da década de 1980 prevaleceram medidas populistas de atração da população proveniente, sobretudo, do Nordeste (Vide TABELA 6). Os projetos do governo Ramos Pereira naufragaram exatamente por causa desta conjuntura favorável à ocupação descontrolada e predatória da base natural do território roraimense.

Nesse cenário de fortalecimento de iniciativas locais, garantido, inclusive, pela nova Carta Constitucional de 1988, o incremento de unidades militares perdeu a prioridade nas políticas do governo central, implementadas na década de 90 . As indefinições relativas ao programa Calha Norte, como visto anteriormente, são exemplo da total falta de direcionamento com relação a empreendimentos militares neste período. ${ }^{172}$

Percebe-se, portanto, tratar-se de um momento marcado por novas tendências de articulação político-territorial na Amazônia, mas que ainda guarda traços da instabilidade geopolítica e econômica que caracterizaram a fase da chamada "consolidação dos regimes democráticos" na América do Sul.

A criação do 4 PEF de Surucucu, em 1988, insere-se num contexto específico, diretamente relacionado à invasão de garimpeiros na área indígena Yanomami ${ }^{173}$, com ocorrência de graves conflitos que afetaram brutalmente essas populações. A divulgação da situação causou um forte impacto na comunidade nacional e internacional, levando o governo a adotar medidas como a criação do pelotão militar nessa área.

De 1975 a 1976, um crescente número de garimpeiros, chegando a 50.000, invadiu a Serra do Surucucus, coração do território Yanomami, em busca de cassiterita. Depois de sérios conflitos armados entre índios e garimpeiros provocados por roubo de roças e abusos sexuais a mulheres indígenas, estes foram retirados pelo Governo Federal. (FUNASA, 1991:12)

\footnotetext{
172 O GRÁFICO 1 mostra um salto apenas no ano de 1989, quando foram executadas as obras de infraestrutura previstas deste o início do programa, mas a década de 90, como se vê pelo gráfico, foi a chamada década perdida para o PCN.

${ }^{173}$ Dois projetos do governo brasileiro que impulsionaram essa invasão foram: a rodovia Perimetral Norte, construída, de 1973/76, na parte meridional do território Yanomami, numa extensão de mais de $200 \mathrm{~km}$, desde sua interseção com a BR-174; e o Projeto Radam, em 1975, quando detecta nessa área uma grande incidência de minerais, como o nióbio e o urânio. Vide área Yanomami na "FIGURA 3".
} 
A retirada dos garimpeiros pela polícia não impediu, entretanto, uma nova invasão na área do rio Uraricoera, em 1980, e nem um novo fluxo migratório, extremamente mais numeroso, no final desta década, quando a situação se tornou absolutamente insustentável.

A situação dos Yanomami alcançou um estado extremamente crítico, a partir de agosto de 1987, com a chegada de milhares de garimpeiros que se utilizaram primeiro dos campos de pouso das missões religiosas e da $F A B$, para depois abrirem novas pistas que, em junho de 1989, alcançavam estimativamente mais de 80 , incluindo algumas na Venezuela. No primeiro semestre de 1989, o número de invasores em busca de ouro era estimado em quase 50.000 (...)". (Ibidem)

Roraima vivia, então, seu apogeu econômico, assentado numa economia que girava em torno do ouro, moeda corrente da maioria das transações que se efetuavam no Estado. Esse momento deixou seqüelas na vida sócio-econômica do Estado ${ }^{174}$.

A garimpagem foi e ainda é uma atividade importante para Roraima. A importância desta atividade está relacionada ao seu papel na formação econômica, social e política de Roraima desde o início deste século. Foram três períodos da atividade de garimpagem: O primeiro iniciou-se em 1912 até 1965; o segundo iniciou-se em 1966 até 1979; o terceiro período iniciou-se em 1980 e pode-se dizer que continua até hoje (RODRIGUES, F. 1996:94)

No plano político, a década de 1990 foi marcada por novas articulações visando à construção da autonomia do nascente Estado e pelo clima de forte antagonismo e conflito pelo poder entre diversos agentes. A disputa pelo protagonismo nos projetos de colonização agrícola, mantida entre o INCRA e o ITERAIMA, e a conseqüente distribuição de terras são, certamente, das querelas mais acirradas e recorrentes até os dias de hoje no quadro institucional de Roraima.

Há de se reconhecer que a governabilidade do novo Estado não se tornou complexa apenas pela injunção da esfera do poder da União sobre o Estado, ou seja, pela tensão de ordem federativa. Constituíram-se outras formas legítimas de poder no território, sendo a mais importante delas a valorização étnica, que acontece num contexto de grande pressão, em toda Amazônia, pela valorização do meio ambiente e de novas formas de utilização do território daí advindas. Estas pressões inscrevem-se na "nova ordem ambiental internacional” ${ }^{175}$, que se desenha no território a partir da inserção do País na "era da globalização".

\footnotetext{
${ }^{174}$ Sobre as transformações ocorridas em Roraima, a partir do garimpo, consultar: RODRIGUES,F.S.(1996)

${ }^{175}$ Vide RIBEIRO, W.C. (2001)
} 
Segue-se, a partir daí uma nova regulação para o Estado de Roraima, com definições de usos de seu espaço relacionadas à malha ambiental. São estabelecidas, então, fortes restrições às formas anteriores de ocupação e mesmo às propostas advindas da elite local, em sua maioria contrária aos contingenciamentos desta "nova ordem".

O território não se restringe mais ao território do Estado, administrativamente constituído, mas passa a englobar o espaço de práticas vivenciadas em várias escalas de referência, da local à global, cuja regulação abre um novo campo de interpretação jurídica no que diz respeito aos limites da ação humana sobre o meio natural. ${ }^{176}(\mathrm{E}$, em relação à própria validade dos parâmetros ocidentais no que se refere aos povos indígenas, grifo da autora)

É neste cenário que políticos locais passam a fomentar a vinda de migrantes, apoiando a instalação de famílias nos lotes que são distribuídos quase aleatoriamente. $O$ processo que se seguiu, normalmente, foi a troca da produção agrícola (que nunca decolou) pelo trabalho no garimpo, mais atraente e promissor se se considera a curta permanência de muitos migrantes que vieram para Roraima.

De 1980 a 1990, a população do Estado quase triplicou (passando de $\approx 79.000$ para $\approx 220.000$ ), o que indica um crescimento de 9,63\% - a maior taxa registrada no País. Mas a realidade não era "explosiva" apenas no sentido demográfico. Era também explosiva por causa da entrada em cena de novos atores políticos, representados por associações e organizações indígenas, apoiadas pela Igreja e por outras organizações com grande capacidade de articulação no cenário local, nacional e internacional.

Paralelamente, a questão indígena passou a permear todas as políticas públicas propostas pelo estado de Roraima. A garantia do direito dos povos indígena às suas terras na Constituição do País passou a ser entendida pela elite local como um grande entrave ao desenvolvimento do Estado, na medida em que as áreas indígenas, somadas às demais áreas de usos restritos, perfazem mais de 50\% das terras de Roraima. (Vide Mapa 3)

Em Roraima, o discurso e a preocupação com o

processo de internacionalização" ganharam força na década de 80 , principalmente após a descoberta e exploração de ouro em áreas indígenas por garimpeiros e o crescimento de pressões, tanto nacional quanto internacional, para a demarcação das áreas indígenas (...). O discurso de "internacionalização de Roraima" foi apropriado, de forma contundente, pelos vários atores sociais, como forma estratégica da defesa de seus interesses. A concepção de internacionalização não assumiu, em Roraima, o entendimento deste processo a partir do predomínio do capital internacional, mas sim, no sentido de uma

\footnotetext{
${ }^{176}$ FIGUEIREDO, A. (1998:235)
} 
concepção conspiratória. Há, em quase todos os discursos, uma conotação de defesa da soberania nacional e do temor de uma apropriação das "riquezas nacionais" por "estrangeiros inescrupulosos" ou "falsos missionários", onde os brasileiros natos estariam excluídos do usufruto de suas riquezas. (RODRIGUES, France 1996)

Conforme descrito pela autora, a relação entre garimpagem, povos indígenas e internacionalização foi estabelecida sem nenhuma intermediação nos discursos produzidos pelos militares e pela elite de Roraima, que deles se apropriaram. O teor do discurso reforça a percepção de uma "ameaça" não tangível em áreas mais isoladas do Estado, justamente onde foi implantado do 5 Pelotão Especial de Fronteira, em 1995.

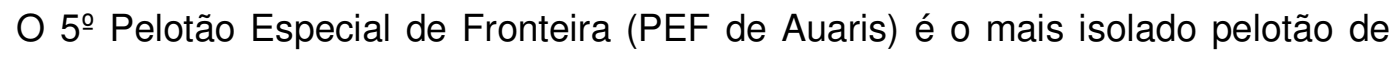
selva do Estado de Roraima. Foi construído próximo à comunidade ye'kuana Auaris, na área Yanomami, que se estende do extremo noroeste do Brasil, até parcelas contíguas pertencentes à Venezuela. (FOTO 8)

FOTO 8



$5^{\circ}$ Pelotão Especial de Fronteira - $5^{\circ}$ BIS - Auaris

Fotos do arquivo pessoal do Sg. CASTRO 
A instalação deste pelotão gerou fortes resistências de setores ligados à Igreja e a outras organizações da sociedade civil. Essas entidades se articularam com mais força a partir de outros centros de debate, muitos deles amadurecidos a partir da Eco- $92^{177}$, quando estes movimentos ganharam visibilidade e passaram a participar, oficialmente, de vários processos decisórios. Essa situação exigiu acriação de um novo "arcabouço democrático", do qual o País se tornou adepto ${ }^{178}$.

A Conferência da "Cúpula da Terra" reuniu representantes de cento e oitenta e sete governos. Contou com a participação direta de cento e quatorze chefes de Estado. Além disso, foi realizado um fórum paralelo com mais de mil ONGs ${ }^{179}$.

A participação de ambientalistas de toda parte, possibilitou a articulação de um movimento em nível nacional e internacional, com forte poder de pressão junto ao governo central, à mídia e a outros setores. Esta nova articulação tem possibilitado o aparecimento de novos protagonistas com poder de decisão, numa escala nunca imaginada no transcorrer das políticas de extrema centralização que marcaram a vida do território roraimense.

No âmbito militar, no início da década de 90, as iniciativas foram tímidas. O Estado passou, claramente, a competir com outros poderes tão ou mais articulados para defender suas posições. Nesta década, o setor militar conseguiu instalar o 5 PEF na área Yanomami ${ }^{180}$, conforme exposto acima, e conseguiu maior autonomia com a Portaria Ministerial $n^{\circ} 085$-RES, de 22/11/91, que transformou o $2^{\circ}$ BEF em Comando de Fronteira

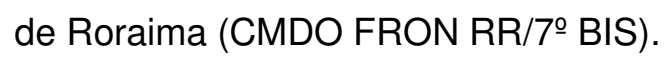

Em conformidade, pois, com as políticas de descentralização desenvolvidas em nível nacional, esse ato conferiu um status importante, uma vez que propiciou ao Estados recém constituído dispor de um comando militar com maior autonomia.

\footnotetext{
${ }^{177}$ A Conferência Internacional de Meio Ambiente e Desenvolvimento foi realizada no Rio de Janeiro, em 1992, quando o conceito "desenvolvimento sustentável" passou a ser incorporado ao discurso oficial. A noção geral veiculada pelo conceito é a de criação de mecanismos para a preservação das condições de suporte do meio físico, às necessidades de produção e reprodução da sociedade no interior do próprio sistema capitalista.

${ }^{178}$ A exemplo deste novo cenário, no Programa ambiental PPG-7, efetivado na Amazônia, a partir de 1991, foi exigida pelo BIRD e demais doadores, a participação de setores da sociedade civil, em todas as etapas de negociação dos projetos, o que obrigou todos os Estados amazônicos que receberam recursos do PPG-7 a incluir estes setores na elaboração e na execução de projetos, envolvendo várias secretarias do governo, instituições de pesquisa e demais atores, antes excluídos do processo decisório.

${ }^{179}$ RIBEIRO, W. (2001:108)

${ }^{180} \mathrm{E}$, este ato já faz parte do novo pacto entre o setor militar e os indígenas, que se inicia nesta década.
} 
E, por último, foi criado o 6ํㅡㄹ $\mathrm{PEF}$, no município de Uiramutã, na fronteira com a Venezuela, em maio de 2002. ${ }^{181}$ (A FIGURA 8, abaixo, mostra a localização exata de todos os pelotões atualmente existentes em Roraima). Esse último PEF, em especial, enfrentou fortes resistências de alguns setores, como da Igreja e de ONGs. Foram onze anos de negociação para que se instalasse, na área de maior conflito no Estado nos últimos anos.

\section{FIGURA 8}

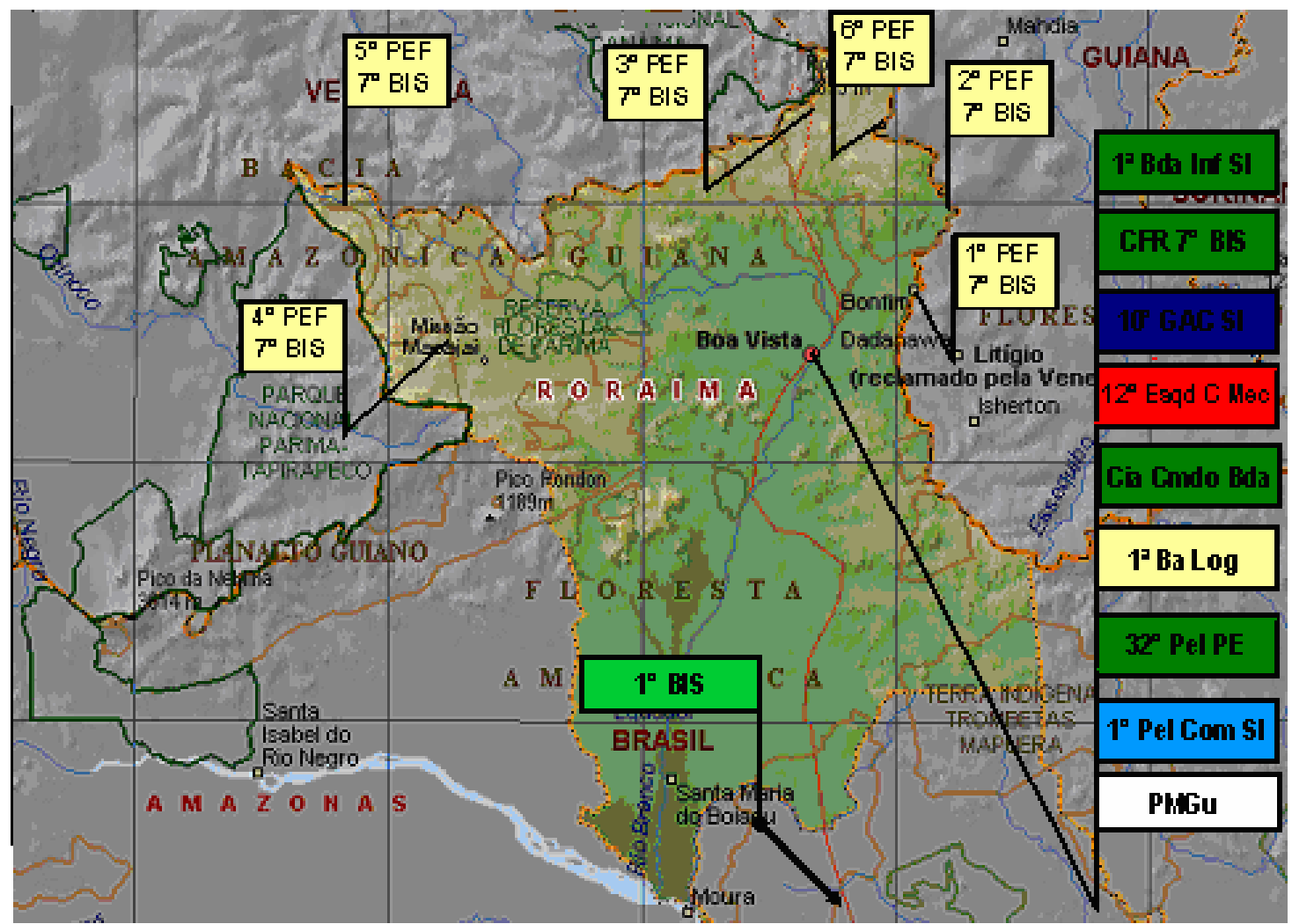

Fonte: Palestra do Gen. Studart. UFRR, 22/09/2004.

Alguns setores, sobretudo ligados ao CIR e a outras entidades que lutam pela anulação do Decreto que criou o município de Uiramutã, em 1995, reagiram o quanto puderam à instalação dessa base militar. O Uiramutã é município enclave na área indígena Raposa/Serra do Sol, homologada pelo presidente Lula em abril/2005.

A questão envolveu "polêmicas existenciais" dos setores mais representativos do Estado: índios, Igreja, militares, setor produtivo, políticos, dentre outros. Em relação ao posicionamento dos indígenas, chamou atenção um texto publicado no Website da

\footnotetext{
${ }^{181}$ A FIGURA 8 mostra a localização exata de todos os pelotões atualmente existentes em Roraima.
} 
Comissão Pró Yanomami-CCPY, que reproduzimos abaixo. São observações traduzidas do líder indígena Davi Yanomami, sobre à presença do Exército, em sua área de atuação:

Os Yanomami querem o Exército como parceiro na defesa das fronteiras do País e no combate às invasões de suas terras. Esse desejo foi manifestado pelos líderes da região do Demini ao Comandante da $1^{\underline{a}}$ Brigada de Infantaria de Selva, General Paulo Studart que, a convite de Davi Kopenawa, visitou no último dia 11 de maio a Maloca de Watoriki, juntamente com oficiais militares, representantes da Igreja, da Funai e da Funasa".

(...) Davi Kopenawa deixou claro ao General Studart que os Yanomami não são em princípio contrários às obras de ampliação da pista de pouso de Surucucus. No entanto, querem que sejam definidas medidas cuidadosas de proteção, em particular, no que se refere à saúde e ao meio ambiente, e seja estabelecido o prazo mais curto possível para a construção. "Nós temos medo que venha gente brava, que traga doenças. Nós não somos contra o Exército proteger a fronteira, como muitas vezes dizem por aí. Pelo contrário, proteger a fronteira das invasões é bom para os Yanomami. Nós ajudamos a proteger a fronteira, expulsamos muitos garimpeiros daqui, mas nós temos medo das doenças dos brancos", afirmou Davi, que fez ainda um apelo ao oficial: "Você tem um coração bom, vem conversar com os Yanomami, queremos que você fale sobre nossas preocupações para o general que vai substituir você". Garantiu também que o interesse dos Yanomami em defender as florestas como patrimônio do Brasil é o mesmo dos militares. ${ }^{182}$

Uma das questões apontadas por lideranças indígenas diz respeito à ocupação de áreas indígenas por militares em períodos anteriores, mais precisamente até meados da década de 1990. As lideranças reclamam de abusos cometidos por militares, que resultavam em gravidez de mulheres indígenas, e do desrespeito à cultura indígena, dentre outros atos que levavam ao acirramento de conflitos entre esses grupos.

Nas poucas entrevistas realizadas com indígenas não foi possível identificar nenhum caso concreto, até porque o assunto é bastante complexo e envolve diferentes concepções e interpretações de "abuso" de ambas as partes. Mas os casos de gravidez indesejada chegam, às vezes, até os postos de atendimento médico. Através de relatos de agentes de saúde da Funasa, sabe-se que algumas crianças não são aceitas por estes motivos $^{183}$.

Para o chefe de Estado Maior do Comando Militar da Amazônia (CMA), general Villas Boas, o Exército é

bastante rígido com normas, mas não pode retroceder à ldade Média e impedir que dois jovens namorem". Ele disse que quase todos os 27 pelotões de fronteira amazônicos estão sediados em áreas indígenas. "Se você pegar a foto de um pelotão, você não consegue distinguir quem é indígena e quem é

\footnotetext{
${ }^{182}$ Website proyanomami.org.br. Acesso em maio/2005

${ }^{183}$ Há uma ampla literatura antropológica em relação ao assunto. Notadamente, na cultura Yanomami, que possui outros códigos relativos às questões de natalidade.
} 
soldado. Porque os índios também são brasileiros, também entram para o Exército e formam a maior parte dos cabos e soldados que atuam na região. ${ }^{184}$

Em artigo assinado pela Associação dos Produtores de arroz de Roraima ${ }^{185}$ é exposto o posicionamento radicalmente contrário dessa Associação à existência de áreas indígenas. A nosso entender, o artigo enforma de modo genérico a concepção dominante nos principais meios de comunicação, que é a mesma da elite local.

O Brasil tem é que disponibilizar para os índios um vasto programa de educação (em todos os níveis) para que eles alcancem, mas sem privilégios, o nível técnico e cultural capaz de, por si só, abominar essas tentativas estrangeiras de impor o ódio, o rancor e a segregação de brasileiros por brasileiros. Assim, podemos sonhar que um dia o $6^{\circ}$ Pelotão Especial de Fronteira de Uiramutã será comandado por um índio que nasceu no Uiramutã, estudou no Colégio Militar de Manaus fez a AMAN - Academia Militar de Agulhas Negras, em Rezende - Rio de Janeiro, chegou a oficial, fez mestrado e até doutorado, mas não deixou de ser índio.

A construção do Pelotão de Uiramutã foi complicada, contestada e cara. Cara não pela obra em si, mas pelas inúmeras comitivas de autoridades que $o$ Exército teve que mobilizar e trazer para mostrar "In Loco" que o que contestavam não haviam lógica e era, antes de tudo impatriótico.

Poderíamos ainda elencar uma série de posicionamentos prós e contras a presença militar em áreas indígenas. No entanto, nosso foco maior é mostrar a atuação dos militares nessas e em outras áreas em que prestam atendimento, enquanto um fenômeno que se recria a todo momento e, assim, adquire novos símbolos e metas. Enfim, interessa-nos analisar o modo pelo qual os militares constantemente submetem os conflitos existentes a uma nova lógica, as quais têm como pano de fundo a lógica da apropriação dos espaços por novas tecnologias que aproximam até mesmo os indivíduos mais isolados do planeta.

O que se pode perceber analisando o panorama, que se inicia com as primeiras colônias militares até a presente constituição do Estado de Roraima, é que este espaço continua uma "verticalidade"186, no sentido miltoniano, uma vez que as principais decisões são tomadas a milhas de distância, a partir do imponente palácio situado na praça dos Três Poderes. A população local não se articula na criação de esferas autônomas de decisão, muito menos conecta-se às lutas políticas de fortalecimento das conquistas alcançadas pelos povos indígenas que ali vivem.

\footnotetext{
${ }^{184}$ Fronteira com a Colômbia terá mais 2,5 mil soldados brasileiros. "Agência Brasil". Artigo assinado por Thaís Brianezi, 19/01/2006.

${ }^{185}$ Artigo publicado no jornal A Folha de Boa Vista em 02 de maio 2002

${ }^{186}$ O conceito é exemplificado na obra de SANTOS, M. (1996)
} 
A população local, atraída por benesses dos governos que se sucederam, parece ser incapaz de propor novos rumos e, juntamente, aos indígenas superar todo tipo de tutela. Os indígenas, no entanto, vêm se organizando com desembaraço, sendo plausível que em pouco tempo possam assumir um protagonismo que surpreenda alguns setores que insistem em políticas tutelares.

Este assunto não será tratado nesta seção, pois demanda uma análise circunstanciada que desviaria nosso foco, no momento. $O$ importante a registrar é que há um novo embate no estado de Roraima, incrementado a partir dos anos 90, com atores bem antagônicos: Governo Federal, Governo Estadual, "elite econômica local", ONGs, igrejas, militares, indígenas (e a lista não para por aí).

A possibilidade de construir novas formas de organização, que não cometam os mesmos erros nem as violências e a exclusão social que se dá em âmbito geral, é um desafio que precisa ser encorajado em todos os setores, não obstante termos que lidar com uma malha territorial regulada por legislação específica, contrapondo-se à malha político-administrativa existente no nível local. 


\section{V.6 A função dos pelotões de fronteira}

Tendo como base os resultados sintetizados a partir dos dados colhidos nas visitas de campo realizadas em 2005 e 2006, aos municípios de Boa Vista, Pacaraima, Bonfim, Uiramutã e Normandia, analisaremos a seguir a atuação dos Pelotões de Fronteira em Roraima

Em Pacaraima e Bonfim, tivemos a oportunidade de entrevistar militares dos pelotões e lideranças locais. Aplicamos questionários com questões abertas e fechadas em relação a alguns aspectos básicos que versam sobre o relacionamento dessas unidades militares na fronteira com outras instituições federais, estaduais e municipais; sobre o trabalho militar em si; bem como sobre os projetos que desenvolvem com as respectivas comunidades.

Um total de cinqüenta questionários foi aplicado junto a representantes de instituições públicas e de lideranças civis e militares dos municípios mencionados. Os questionários foram diferenciados, segundo a categoria dos entrevistados.

Para os comandantes sediados em Boa Vista e Manaus, as questões foram divididas em cinco itens: i - identificação; ii - atuação militar na área do respectivo comando; iii - projetos e parcerias existentes na área de responsabilidade do comando ${ }^{187}$; iv - aspectos relacionados à vida ${ }^{188} \mathrm{e} ; \mathrm{v}$ - envolvimento com a questão ambiental ${ }^{189}$.

$\mathrm{Na}$ área dos Pelotões, além destes itens, tentamos compreender o relacionamento das Forças Armadas com a comunidade e a percepção dos atores entrevistados em relação à "fronteira". Buscava, por meio da entrevista, fazer com que os militares pudessem nos indicar qual a percepção das ameaças mais freqüente nas áreas fronteiriças e, por outro lado, levantar as formas pelas quais a recente cooperação internacional possa estar produzindo uma territorialidade diferente da que existiu ao longo do período de contensão. ${ }^{190}$

\footnotetext{
${ }^{187}$ Foram apresentadas questões referentes à parcerias com instituições civis de todos os setores no nível federal, estadual e municipal, bem como em relação ao PCN, SIVAM e SIPAM.

${ }^{188}$ Nos PEFs, tudo se resume ao lema: "vida, combate e trabalho". E a vida, neste caso, envolve também família, lazer e a sobrevivência no PEF (cultivo, criação de animais etc).

${ }^{189}$ Em relação a este aspecto, apesar do material recolhido, não houve tempo para completar esta análise. Tentamos apenas inserir alguns aspectos que interferiram diretamente em algum ponto da discussão feita nesta tese.

190 Os resultados, no entanto, são ainda muito incipientes para podermos completarmos a análise desta questão, mas nos ajudou deveras na compreensão de uma série de novos elementos colocados para a realidade fronteiriça.
} 
Para as instituições civis que atuam na área dos PEF, fizemos as mesmas perguntas, tendo o cuidado, porém, de fazer as adaptações aos respectivos contextos. Já para as lideranças indígenas, que vivem nas áreas dos PEFs, focamos quatro aspectos básicos: i) a vida na comunidade; ii) a modernidade que interfere nas aldeias ${ }^{191}$; iii) o relacionamento com os pelotões, e iv) a questão da saúde. ${ }^{192}$

A maior parte das entrevistas foi realizada no $3^{\circ}$ Pelotão Especial de Fronteira/3ํㅏF do município de Pacaraima, por ser a principal saída externa de Roraima, e onde estão instalados vários órgãos do governo federal. O local também é um importante posto de intercâmbio com a Venezuela, com grande movimentação de cargas, de pessoas e de trocas, realizadas no comércio fronteiriço das "cidades gêmeas": Pacaraima/Santa Helena do Uairén.

Estabelecido em Roraima na década de 1970, o 3 PEF foi uma das primeiras "unidades de fronteira" e se constituiu, sobretudo até os anos 90 , num importante pólo de apoio e de estruturação do espaço urbano do seu entorno.

Como visto anteriormente, após essa data, foram alteradas as estratégias de ocupação nesta fronteira. O município de Pacaraima, constituído em 1995, na área indígena de São Marcos, vive uma grande indefinição quando à forma de inserção que será adotada neste novo cenário de reconhecimento dos povos indígenas que ali vivem.

O comandante (até 2006) do $3^{\circ}$ PEF, o Ten. Maurilio Ferreira da Silva Júnior, 24 anos, proveniente do Amazonas, vivia no PEF de Pacaraima com a família. Ele me pareceu muito bem adaptado às condições locais e às tarefas de um comando de sessenta e seis homens, para uma dimensão territorial de centenas de quilômetros ${ }^{193}$.

Notamos, entretanto, que são parcos os recursos para o grau de responsabilidade atribuídos aos PEFs. No geral, observa-se um descompasso com relação à alta tecnologia empregada no mundo contemporâneo na área de defesa e segurança. A precariedade que se observa no local diz respeito também a todo o entorno representando pelo município de Pacaraima, que, com uma população atual estimada em 8.000 hab $^{194}$, sequer tinha agência bancária, quando da realização das entrevistas.

\footnotetext{
191 Incluímos neste item os aspectos da comunicação via rádio (para os Yanomami), a educação e o relacionamento mais amplo com o "mundo civilizado".

192 Novamente, aqui também não foi possível utilizar todo o material recolhido.

${ }^{193}$ Não conseguimos obter até o momento as delimitações exatas, em termos de $\mathrm{km}^{2}$, da atuação de cada PEF. Apenas vimos uma delimitação feita sobre mapas utilizados nos Refrons (reconhecimento de fronteira).

${ }^{194}$ Vide TABELA 1.
} 
A questão da infra-estrutura é só uma das faces do problema, a qual, aliás, é normalmente bem suportada pelos militares durante o curto período de tempo em que permanecem nesse locais, até serem transferidos. A questão de que mais se queixam é a distância das famílias. Mesmo quando vêm com esposas e filhos, todos têm que lidar com $\mathrm{o}$ isolamento e o abandono da vida urbana de que desfrutavam nas cidades de origem. $\mathrm{A}$ esse respeito é curioso notar que, nos círculo de militares que vêm para a Amazônia, se costuma afirmar que são freqüentes as separações conjugais, em decorrência de falta de adaptação de algumas famílias.

Também a saúde foi apontada como um dos problemas mais sérios enfrentados por aqueles que necessitam de tratamento especializado. Entrevistamos um militar do $3^{\circ}$ PEF que recentemente tinha perdido um filho de poucos meses porque 0 avião não chegou a tempo para fazer o transporte da criança doente até um hospital que lhe prestasse socorro.

A estrutura mínima de sobrevivência dos PEFs é composta por criatório de pequenos animais, horta e cantina. Algumas esposas contribuem com algumas tarefas como a produção de alimentos; há aquelas que se dedicam à área educacional, seja lecionando na comunidade ou oferecendo cursos na própria vila militar.

Entrevistamos a esposa de um militar que viveu alguns anos nos "PEFs de selva", que teve uma experiência de aproximação dos indígenas bastante singular. Sua comunicação com essas comunidades foi possível a partir do forte interesse que a mesma possuía em conhecer essas culturas e interagir com as mesmas. Pudemos perceber pelas experiências relatadas e pelas fotos que vimos, que, neste caso, houve "trocas interculturais" relevantes.

De maneira geral, os PEFs da Amazônia acabam se constituindo em pólos de dinamismo sócio-econômico nas localidades onde são instalados. Por isso, representam, senão a única, com certeza a principal presença do Estado nas áreas mais remotas. Por isso, cumprem um papel fundamental no cotidiano dessas comunidades, uma vez que seus membros são requisitados para todas (ou quase todas) as tarefas e eventos que ocorrem. A foto a seguir dá uma idéia do grau de integração a partir do trabalho dos militares na região. 
FOTO 9

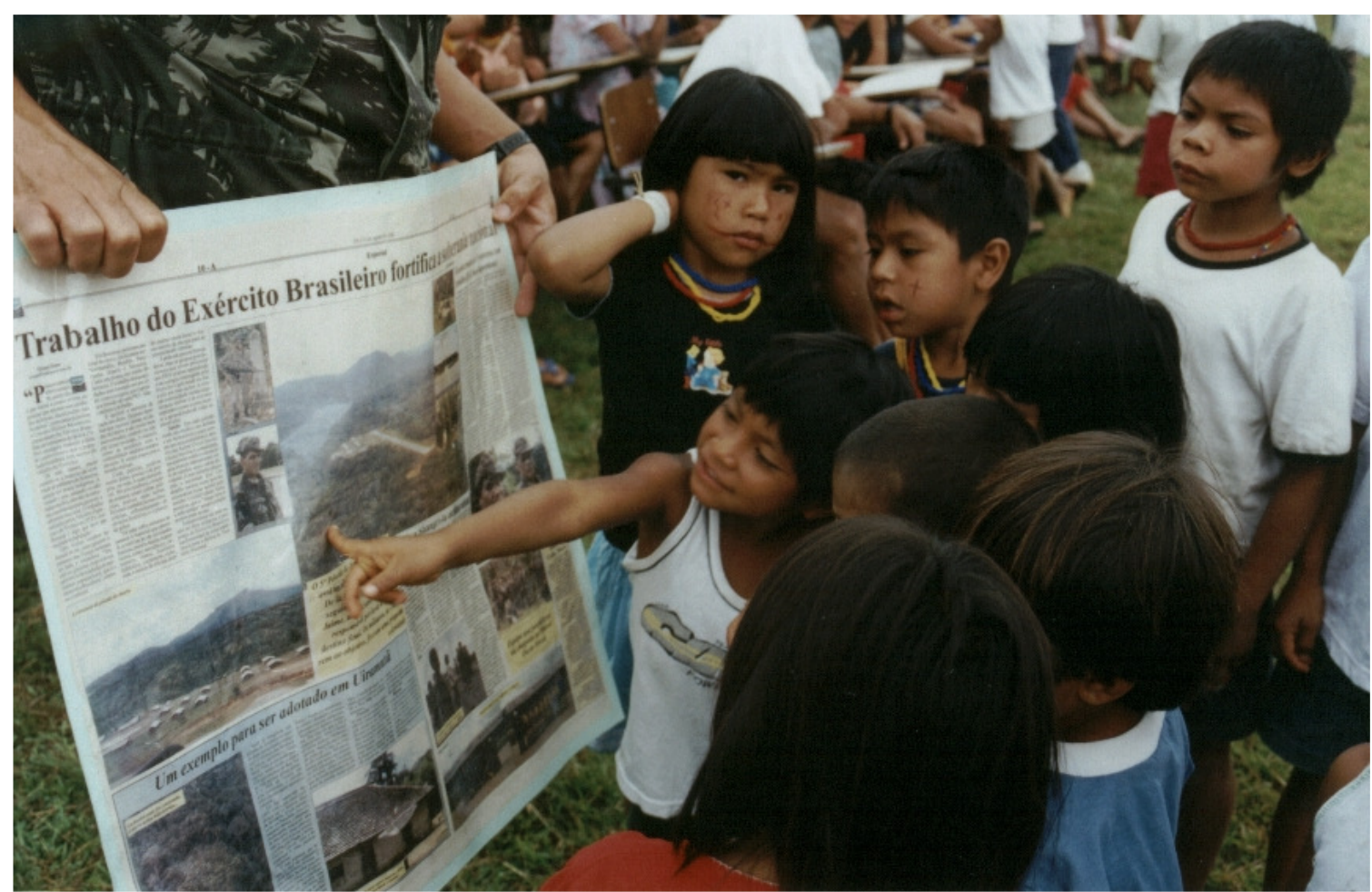

Visita de alunos Yekana ao PEF de Auaris

Foto do arquivo pessoal do Sg. CASTRO

O projeto padrão para implantação de um PEF prevê, além do quartel e das residências, a construção de instalações como posto médico, escola, quadra esportiva, bem como a infra-estrutura básica de saneamento, eletrificação, comunicações, pista de pouso, etc. (FOTO 8)

No PEF, além dos espaços reservados ao Exército, há outros reservados a órgãos federais, destinados a atender os serviços básicos prestados à comunidade. No entanto é freqüente o Exército acabar sendo um dos únicos a cumprir muitas funções, dada as carências de pessoal, de equipamentos, dentre outros fatores, que impedem presença de outros órgãos no local.

Quase todos os pelotões de fronteira têm uma característica praticamente idêntica: neles há onze residências, das quais cinco são para oficiais e seis para subtenentes e sargentos. Além disso, há outras instalações do próprio pelotão, como alojamento para cabos e soldados, refeitórios, etc. O lema dos PEFs é "vida, combate e trabalho. 
Quanto ao "trabalho" que realizam, os PEFs desenvolve tanto atividades de manutenção da infra-estrutura existente no próprio PEF, através de serrarias, marcenarias, olarias, oficinas mecânicas, etc., quanto fazem atendimento à comunidade local.

Muitos dos pelotões têm uma pequena represa e uma microusina hidrelétrica que fornece energia para o pelotão e para as comunidades vizinhas, sejam indígenas ou de pessoas que moram na área. É de responsabilidade do PEF manter essas e outras instalações ali presentes, segundo a atribuição de cada um.

O 3ํPelotão Especial de Fronteira possui um efetivo de sessenta e seis militares, sendo trinta e cinco do Pelotão de Fuzileiros de Selva, responsável pela parte operacional, ao passo que uma seção com trinta e um militares é responsável pela parte administrativa. A maioria do efetivo veio de outros Estados da Federação, notadamente do Nordeste - quase sempre os de menor patente -, e do Sudeste, os mais graduados. Somente os cabos e soldados são, em sua maioria, de Roraima ${ }^{195}$.

Com uma grande rotatividade anual, o efetivo existente fica responsável por guarnecer as fronteiras e cooperar nas ações sociais para as quais foram convocados. Além disso, realizam operações em prol da "Garantia da Lei e da Ordem", uma vez que têm poder de polícia, recentemente atribuído aos comandos localizados na faixa de fronteira.

A atuação na área de segurança e defesa compõe o campo de "combate", que se situa numa interface com o "trabalho", uma vez que as situações de "combate" se dão mais no nível de exercícios preparatórios, às vezes, combinados com outras forças: a Aeronáultica e a Marinha.

Como parte de uma organização militar, o PEF tem que estar apto, prioritariamente, para o cumprimento de sua missão de natureza militar que é o "combate" - a proteção das fronteiras. As outras duas missões - "vida" e "trabalho" - são de natureza especial. Esta é uma questão importante a ser debatida, pois o pelotão acaba atendendo uma série de demandas de caráter social, tão ou mais freqüentes do que aquelas de caráter tipicamente militar.

\footnotetext{
195 A composição dos PEFs é praticamente a mesma em todos, bem como a participação majoritária de pessoal originário de outros Estados da Federação. Isto é um reflexo da realidade do Estado, basicamente composto por migrantes, que chegaram após a década de 80.
} 
Os PEFs foram concebidos para atuar na área de vigilância e defesa de espaços limitados ao local onde se situa. Na sua retaguarda, têm, no caso de Roraima, a Brigada, em Boa Vista, que por sua vez, é amparada por unidades maiores, baseadas em outras áreas do território nacional.

Os pelotões também fazem um constante reconhecimento da área de fronteira, estabelecendo e mantendo os marcos físicos que existem, como o do Brasil/Venezuela, onde o $3^{\circ}$ PEF se situa. Os militares do PEF também são responsáveis pelo controle do pouso de aeronaves, nas pistas abertas junto aos mesmos.

No âmbito daquilo que os militares do Exército denominam "vida", são realizadas atividades ligadas à sobrevivência do próprio pelotão, como caça e pesca, cultivo de alimentos e lazer, dentre outros. No aspecto "vida", para o 3 PEF, destaca-se o contato com a Venezuela. À época em que realizamos nossa pesquisa, havia sido firmado um convênio do governo brasileiro com a Universidade Grand Sabana, por meio do qual se foram garantidas cento e oitenta vagas para brasileiros em diferentes cursos, inclusive medicina.

Estas e outras oportunidades de intercâmbio animam a vida no PEF e abrem perspectivas mais atraentes de capacitação para o militar e para sua família, bem como para a comunidade em geral. Servidores de outros órgãos federais também inscreveramse nos cursos oferecidos na "Gran Sabana". Há uma unanimidade em afirmar que os contatos interfronteiriços são ricos e se ampliam, informalmente, enquanto o governo não providencia as condições formais de intercâmbio.

No outro extremo da fronteira, situam-se os PEFs de Surucucus e Auaris. A vida nesses pelotões, é absolutamente diferente de qualquer experiência que os militares já tiveram. Apesar de todas as privações do mundo urbano, todos ressaltam o grande aprendizado que é a vivência nessas áreas. Consideram extremamente gratificante poder incluir em seus currículos este tipo de experiência. A foto abaixo mostra uma data especial no calendário de eventos locais. 


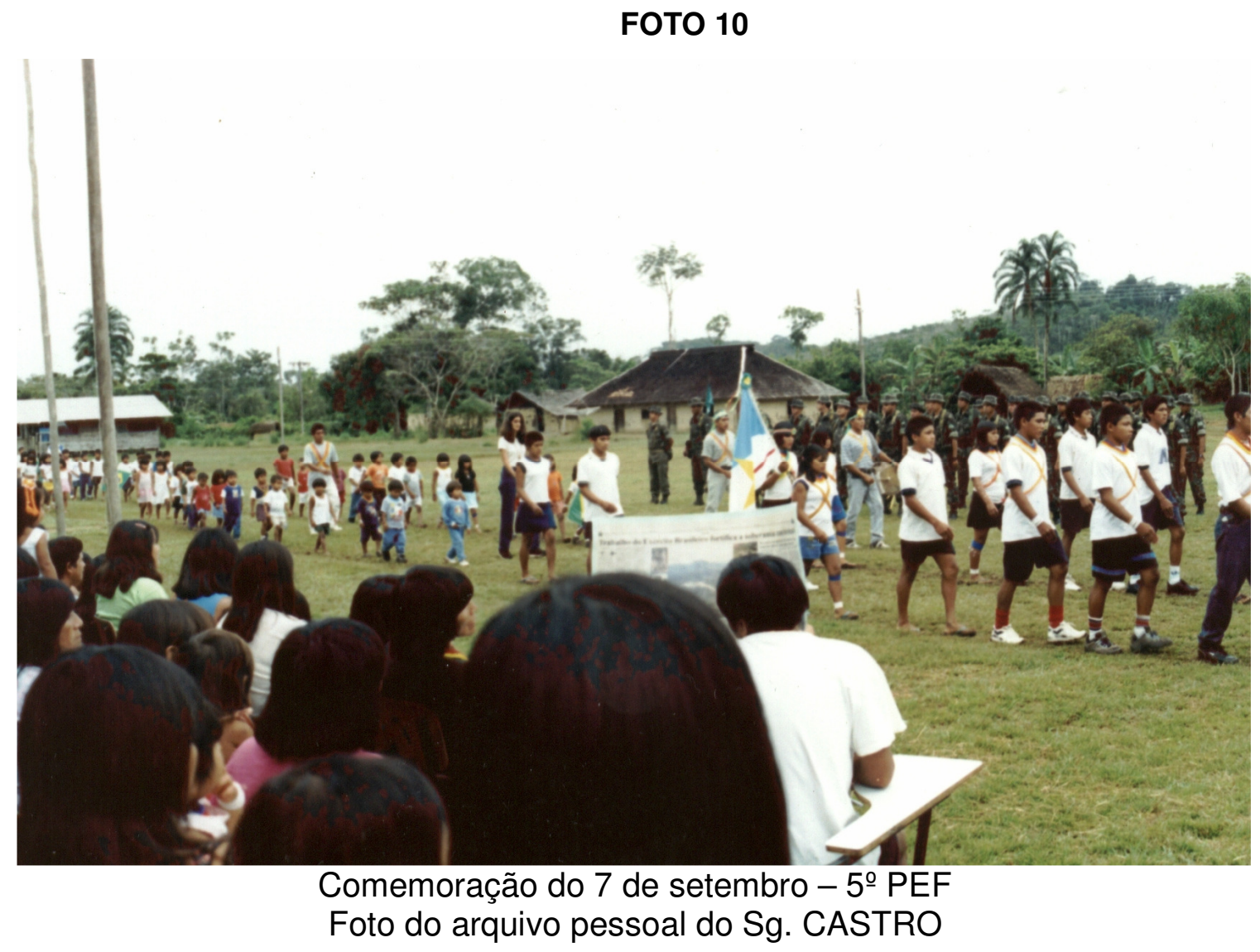

No geral, os militares que vêm transferidos de unidades militares maiores, ressaltam a "supressão" da hierarquia nos pelotões de fronteira. Aqui todos são iguais, não há espaços diferenciados para refeições, as acomodações são todas simples e o companheirismo é o elemento central em todas as tarefas que desempenhamos, conforme afirmou o cabo Reis. Esse mesmo aspecto foi confirmado por outros entrevistados.

O Capitão Vicente de Paulo Souza, de vinte e oito anos, (Cmd da Cia Especial de Fronteira do $7^{\circ}$ BIS: Pacaraima, Bonfim, Normandia, Uiramutã, Auaris e Surucucu), um carioca, aparentemente muito jovem para o grau de responsabilidade que assume, surpreende pela capacidade de percepção dos problemas que enfrenta e pelo empenho em tentar resolvê-los.

O Capitão Vicente passa quinze dias em cada um dos seis pelotões do Estado e, quando chega tem de solucionar todas as pendências encontradas, que vão desde a falta 
de equipamentos, à manutenção da área, passando por problemas psicológicos resultantes do isolamento da turma, afirma. ${ }^{196}$

Em relação às questões fronteiriças, foram destacadas: educação, saúde, problemas fundiários, corrupção (e/ou má gestão); falta de infra-estrutura; problema de segurança e defesa; problema ambiental e outros de menor destaque. É importante perceber que as questões de segurança e defesa parecem não afetar estas comunidades, seja porque estão bem guarnecidos, ou, talvez, porque não as consideram relevantes para suas prioridades.

Segundo os comandantes dos pelotões visitados, não há registros de ocorrências que possam ser configuradas como invasão/intromissão na nossa soberania, biopirataria ${ }^{197}$ ou outro fator relevante, como às vezes é divulgado pela mídia.

Um dos resultados da pesquisa aponta que a guarnição da fronteira desfruta junto à comunidade do mesmo grau de importância que ela dispensa à manutenção da infraestrutura e ao atendimento social. Todos também reconhecem, logo depois, o apoio aéreo oferecido pela $F A B$, sobretudo, para o atendimento aos grupos indígenas. Em terceiro lugar, a assistência às comunidades carentes, notadamente, na área de saúde e educação.

No aspecto das parcerias e dos projetos institucionais, os resultados apontam haver bom relacionamento entre as instituições federais que operam na área (Exército, PF, IBAMA, Receita Federal, Secretaria da Fazenda, Anvisa, Polícias, dentre outras), mas apontam também haver pouca intersecção destas com outras instituições de nível municipal. No nível estadual, só entrevistamos a polícia, que opera também em sintonia com os agentes federais.

Já o relacionamento do $3^{\circ}$ PEF com o exército venezuelano mostrou-se de amizade e parceria, em vista das missões afins, exercícios militares e prática de esporte conjuntos. Com relação à Guarda Nacional da Venezuela, não ocorrem estas parcerias, embora o relacionamento também seja de cordialidade.

\footnotetext{
${ }^{196}$ Entrevista concedida em abril/2005.

${ }^{197}$ Uma das perguntas do nosso questionário versava sobre este aspecto da "soberania", apesar das notícias sobre contravenção em áreas de fronteira, somente o representante do IBAMA, o agente da PF, um representante da Câmara dos vereadores de Pacaraima e um militar (Tenente do Exército), das autoridades entrevistadas (num total de 20 em Pacaraima), afirmaram ter acompanhado algum tipo de ilícito que afete a soberania do País.
} 
Apesar das parcerias, percebeu-se que as instituições brasileiras que operam na fronteira ainda não conseguem desenvolver projetos comuns e que têm pouca informação a respeito do trabalho que o "parceiro" desenvolve. A integração entre políticas setoriais é, portanto, bastante embrionária.

As instituições operam com os dados do SIPAM, a partir dos produtos cartográficos que são gerados pelo sistema e servem ao planejamento de vários órgãos. Quanto aos equipamentos instalados, ainda não há pessoal capacitado para operá-los.

Nas entrevistas realizadas com indígenas e com agentes de saúde, constatou-se que os rádios e antenas do SIPAM têm ajudado muito na busca de socorro na área de saúde. Também servem para alertar as autoridades sobre a existência de ilícitos na área. Esta é uma das funções da torre situada no PEF de Auaris. FOTO 11

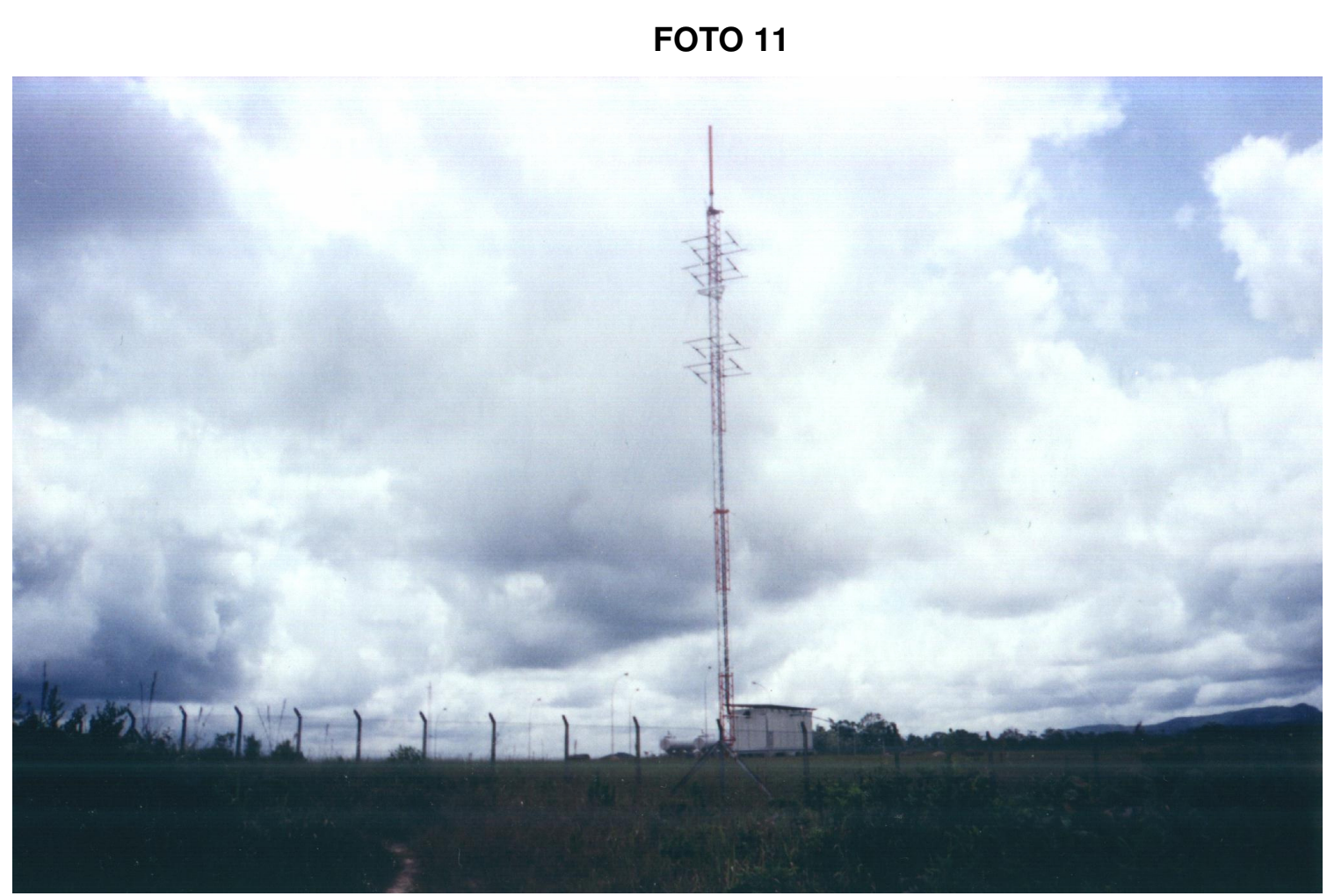

Foto do arquivo pessoal do Sg. CASTRO

A percepção da comunidade em relação à contribuição do $3^{\circ} \mathrm{PEF}$ para a cidade de Pacaraima é muito marcada pelas ações cívico-sociais, voltadas, sobretudo, para a área de saúde. Os PEFs têm-se destacado pelo apoio à área de saúde em toda a fronteira norte do País, tão carente de infra-estrutura. 
Nos Pelotões Especiais de Fronteiras (PEFs), por mais remota que seja a área instalada, tem-se dado uma estrutura com médico, dentista e um laboratorista. Esses profissionais exercem um serviço imediato para as populações brasileiras e até para estrangeiros.

É comum em todos os PEFs recebermos estrangeiros. Isso acontece em Bonfim, com os cidadãos de Lethem, em São Gabriel da Cachoeira, com os colombianos e em Tabatinga, com peruanos e colombianos". Avelino diz que essa demanda acontece devido à boa parte de os países da América do Sul não contar com um atendimento dos moldes do Sistema Unificado de Saúde (SUS), voltado para as classes sociais de baixa renda. ${ }^{198}$

Por fim, a maioria dos entrevistados destacou o bom relacionamento com a comunidade e a participação do PEF nos eventos festivos. Dependendo do comandante há maior ou menor aproximação com a comunidade. Os entrevistados que não tiveram esta percepção, enfatizaram a falta de continuidade dos relacionamentos, em vista das constantes trocas de efetivos, impedindo qualquer avaliação.

É bom lembrar que a percepção do trabalho social desenvolvido pelos militares e a maior aproximação com a comunidade é mais freqüente nas áreas dos pelotões de fronteira, pois na cidade, mesmo em Boa Vista, onde a população não chega a 250.000 habitantes, tudo permanece dentro dos padrões de formalidade comum ao "ethos militar" castrense.

${ }^{198}$ Diário do NE 29/09/05 Amazônia - GOVERNO tenta fixar população nas fronteiras. 


\section{CONCLUSÃO}

Analisamos, ao longo desse trabalho, as ações que denotam uma "nova geografia militar" na Amazônia, tendo como foco a ampliação de bases militares e o novo papel que os militares vêm assumindo nesta região.

Conforme acreditamos ter demonstrado, essas ações fazem parte de um programa mais amplo de reorientação da questão militar no País, que desde o início de 1990, vem dando ênfase ao binômio Amazônia e soberania nacional. O discurso militar se apropriou desse tema, que foi usado amplamente a partir desta época.

No início do novo milênio, o processo de amadurecimento dessa questão pode ser percebido por meio de uma série de medidas de ordem prática, como as que foram apontadas nos capítulos anteriores, e de ordem legislativa, como a criação do Ministério da Defesa, em junho de 1999.

É fruto também desse processo, o aperfeiçoamento da política de defesa, delineada através de decreto mais recente ${ }^{199}$, que pressupôs a inclusão de temas voltados especificamente para a região amazônica, identificando-a pelo seu grande potencial de riquezas minerais e de biodiversidade.

A regionalização decorrente de novos usos da malha ambiental já é evidente na Amazônia brasileira, mesmo que ainda não haja uma ação coordenada na área da defesa e segurança para lidar com esses novos signos inscritos no território. A citação a seguir dá uma idéia do significado do vetor ecológico:

Hoje, quase 9\% do território brasileiro é protegido por meio de unidades de conservação. Deste total, 90\% encontram-se aqui na região amazônica. Na região Amazônica, o Governo Brasileiro implantou e vem administrando 138 áreas protegidas, equivalentes a 52 milhões de hectares, consistidos tanto em Unidades de Conservação de Proteção Integral quanto em Unidades de Uso Sustentável. Somente no Governo Lula foram criadas 8,3 milhões de hectares de terras protegidas na Amazônia e "interditadas"(...) outros 8,2 milhões de hectares (...) A participação do Exército, em alguns destes programas a partir da sua Política de Gestão Ambiental e da Diretriz Estratégica de Gestão Ambiental é um exemplo de transversalidade nas políticas publicas e consolida o papel das forças armadas na preservação do meio ambiente, uma parceria, em particular nos ecossistemas localizados na fronteira terrestre, sem a qual seria institucionalmente impossível combater o desmatamento criminoso.,200

\footnotetext{
${ }^{199}$ Decreto $\mathrm{n}^{\mathrm{o}}$. 5.484, publicado em junho de 2005, que versa sobre a Política de Defesa Nacional. Pode ser consultado através do site www.defesa.gov.br. Acesso em 18/12/2006.

${ }_{200}$ Palestra: "Politica de proteção e conservação de espaços territoriais e política de gestão de florestas públicas." CMA/2006
} 
Após uma época de fausto, em que foi responsável pela construção de praticamente toda a infra-estrutura de que dispõe Roraima, pode-se afirmar que a atuação do setor no militar nesse novo papel pode ser classificada como ainda incipiente e faz parte de um escopo vinculado mais às ações cívico-sociais que a um pensamento estratégico sobre as questões ambientais.

Em entrevista realizada com o comandante do $7^{\circ} \mathrm{BIS}$, no que concerne aos planos elaborados para este setor foi destacado a inauguração do mini-zoológico em Boa Vista, e as várias atividades de educação ambiental, ligadas, sobretudo, à preservação da fauna.

A realização de projetos desta natureza pelo setor militar coincide com a prioridade dada à Amazônia no discurso ambiental do País, e, principalmente, no âmbito internacional. $O$ elo estabelecido entre as políticas de defesa e de segurança e a Amazônia, como espaço sócio-ambiental privilegiado destas políticas, vem sendo percebido por especialistas de várias áreas; como se vê adiante:

No começo da década de 90 era notório, principalmente em matérias na imprensa escrita e televisisa, que a Amazônia era vista como uma questão nacional associada aos militares, sobretudo ao Exército. (...) essas matérias tendem a ver como uma justificativa para uma nova função institucional dos militares. (...) Uma rápida olhada em revistas especializadas, sites militares e artigos acadêmicos indica uma possível consolidação da idéia de que a Amazônia só é percebida como questão nacional enquanto questão militar. (CASTRO, 2006:143).

Pudemos verificar que, de fato, no cenário de Roraima, a convergência entre a causa militar e as causas ambiental e indígena compõem uma nova legitimidade em relação à estrutura centralizadora da União, agora combinada a novos atores oriundos de diferentes esferas. A gestão compartilhada do meio ambiente, inaugurada com a participação do País no PPG-7, mencionado anteriormente, levou a um pacto de poder que, na maior parte das vezes, prescinde da fragilizada esfera pública local.

(...)articulando, antes, segmentos locais isolados às organizações internacionais elou nacionais, alinhadas ou não ao Estado central, em torno de interesses convergentes pautados, via de regra, a partir das fontes de financiamento vindas de fora. (...) construindo descontinuidades espaciais ainda difíceis de ser avaliadas. (FIGUEIREDO,A., 1998:250/251)

Roraima entra para o centro do debate ambiental e militar por razões consideradas estratégicas não apenas por sua posição geográfica. A interconexão com o Caribe, a partir da fronteira com a Venezuela e a Guiana, e o fato de ainda possuir áreas não incorporadas à economia do País, ricas em biodiversidade e em minérios, dão sustentação a esse discurso renovado de justificação para o papel das Forças Armadas. 
A presença de povos indígenas de várias etnias, cujo ícone são os Yanomami - os mais isolados do planeta - também é um fator de relevante interesse para a nova geopolítica que se desenha no hemisfério sul do continente americano.

Vários são os caminhos utilizados para a compreensão deste cenário. Partimos do pressuposto de que as Forças Armadas protagonizam importantes projetos em áreas mais isoladas do contexto nacional, a exemplo do que acontece na maioria dos municípios roraimenses. Ademais, em Roraima, as Forças Armadas sempre tiveram papel de destaque em todos os setores da vida pública e no cotidiano do lugar, o que confere a esse espaço um certo "ethos militar", conforme exposto no capítulo IV.

Pode-se afirmar que, no contexto atual, as ações complementares de cunho sócioambiental realizadas pelas Forças Armadas em Roraima certamente têm a mesma ênfase que, em décadas passadas, teve a construção da infra-estrutura no antigo Território Federal. Outros tempos, outros ventos.

O apoio que as Forças Armadas oferecem a comunidades isoladas não é, meramente, logístico, visto que os militares estão presentes em todas as ações para as quais são requisitados. E,posso afirmar que a agenda é sempre cheia nessa região.

Os militares (Exército) são chamados para fazer a construção e a manutenção de estradas; reparos em prédios do patrimônio público, manutenção de praças e jardins,mas também para animar as festas com sua banda de música, para dar palestras nas escolas, dentre outras atividades. A lista é grande. Em entrevista à autora, o Cel. Fontoura afirma (que sua unidade) ${ }^{201}$ :

(...) tem buscado aproximar-se da sociedade em geral, abrindo seus portões para apresentar seu mini-zoológico, ministrando palestra sobre educação ambiental, e também difundindo a idéia da revitalização do marco histórico "Forte São Joaquim do rio Branco". (...) Tais atividades trouxeram ao Batalhão em 2006 aproximadamente 20 mil pessoas, particularmente estudantes."

Também pudemos concluir que programas originados no meio militar, como o SIVAM, o SIPAM, e o Calha Norte, adquiriram um novo modus operadi, a fim de incorporar demandas sociais e buscar uma maior aproximação com as comunidades e, ao mesmo tempo, com as instituições que operam na Amazônia.

E, no interior desta questão, mostramos como as novas tecnologias presentes no SIVAM/SIPAM podem produzir novas territorialidades no cotidiano de localidades isoladas

${ }^{201}$ Entrevista com o Cel. Zenedir da Mota Fontoura, C Fron RR/7º BIS, realizada em junho/2007. 
e em que dimensão representam uma nova forma de poder e de relacionamento com diferentes agentes locais.

Nossa investigação nos permitiu constatar que Roraima ainda não se consolidou como Estado autônomo, apesar de toda a infra-estrutura deixada pelos governos militares, a chegada da energia elétrica da Venezuela e do asfaltamento das rodovias que a ligam a Manaus e aos dois países vizinhos, Venezuela e Guiana ${ }^{202}$.

Os conflitos que aqui se dão assumem dimensões próprias. A disputa pela terra, por exemplo, não ocorre em Roraima como em outras partes do Brasil, em que geralmente antagonizam pequenos e grandes proprietários, posseiros, empresas agrícolas ou outros agentes.

Em Roraima, o embate central se dá entre índios, não índios e seus aliados, como a imprensa tem noticiado. O período pós-homologação da área indígena: Raposa/Serra do Sol, em abril/2005 é marcado pelo acirramento dos discursos. Os códigos e conceitos em questão nessa disputa parecem ser radicalmente antagônicos.

Em contraste, procuramos mostrar, através de autores como REPETTO (2002) e MONTANARI JR. (2005), que há caminhos alternativos promissores de intercâmbio com essas comunidades. E, mais ainda, que os indígenas percebem que os conhecimentos científicos e tecnológicos são importantes para manter a sobrevivência material e sua cultura $^{203}$.

$\mathrm{Na}$ disputa por este espaço político convergem ONGs, Igrejas ${ }^{204}$, instituições nacionais e internacionais. Mais complexo ainda se torna o painel quando o próprio estado de Roraima, através do seu governo e de setores expressivos da sociedade, se contrapõe à União, responsável por áreas consideradas vitais para a gestão local.

O cenário geopolítico em Roraima é, portanto, complexo e multifacetado e não há como apreendê-lo se se observa e considera apenas um dos seus ângulos. Afinal, são

\footnotetext{
${ }^{202} \mathrm{O}$ asfaltamento da BR-401, que liga o Brasil à República Cooperativista da Guiana, não tem continuidade na Guiana. Como visto anteriormente, o processo esta em negociação.

${ }^{203}$ Nas entrevistas realizadas com lideranças Yanomami, na sede da CCPY, em Boa Vista, percebemos que as lideranças jovens presentes tinham preocupação com a educação. Foi nos informado que em sua aldeia existiam em torno de dezoito indígenas que falavam o português, e uma das maiores preocupações era a alfabetização na própria língua Yanomami, que, segundo depoimento, estava se perdendo pela ausência de registros escritos, ademais notamos o fascínio que os jovens estão tendo com a tecnologia do rádio.

204 "Existem diversas associações indígenas, algumas ligadas à Igreja Católica, que se constitue na maior força contra os agentes políticos e econômicos, apoiados pelos governantes de Roraima. Sua ação se dá através do CIR, fundado em 1985. Outras associações, tem-se formado, desde a década de 80, em oposição ao CIR.." (SANTOS, 2004:245)
} 
vários os atores com papel importante na política local e, ainda que tenhamos destacado as ações das Forças Armadas, e não a de outros atores como a igreja, e as ONGs, que exercem forte predomínio na relação direta com os indígenas, reconhecemos que todos exercem papéis importantes para a construção desse Estado.

Constatamos por fim, que a organização do espaço social de Roraima continua a ser concebida a milhas de distância daqui. Prova disso é que as Forças Armadas ainda têm papel importante no Estado, apesar do seu distanciamento corporativo e do antagonismo em conciliar a hierarquia militar com a gestão participativa, base do discurso hegemônico desde os anos de 1990.

Concluímos, por fim, que as Forças Armadas ampliaram sua atuação na Amazônia, por meio de outras frentes de atuação e passaram, assim, a protagonizar um novo momento, num novo cenário.

De resto, cabe ainda destacar que a maior concreção desse novo papel são a criação e a manutenção dos PEF's, localizados em áreas isoladas, e de outras organizações militares, que atuam em áreas consideradas importantes à soberania do País, agora também relevantes pelos seus aspectos ambientais, étnicos e culturais. 


\section{REFERÊNCIAS BIBLIOGRÁFICAS}

ACSELRAD, Henri. O Zoneamento Ecológico-Econômico e a multiplicidade de ordens sócio-ambientais". Seminário "Avaliação de Metodologia do ZEE para a Amazônia", realizado em Manaus, de 3 a 5 de outubro de 2000. MMA/PPG-7/GTZ.

AGOSTINHO, J. Subsídios à discussão de um plano de desenvolvimento sustentável para o Estado de Roraima. Tese de doutorado do Departamento de Geografia da FFLCH/USP, São Paulo, 2000

ALBERT, B. Indian Lands, Environmental Policy and Military Geopolitics in the Development of the Brazilian Amazon: The case of the Yanomami. Development and Change (SAGE, London, Newbury Park and New Delhi, Vol. 23, Págs. 35-70. 1992

ALVES, Cláudia L. E. (org.) Formação do Espaço Amazônico e Relações Fronteiriças. Seminário organizado pelo Centro de Ciências Sociais e Geociências da UFRR - no período Out/Dez. 1997

AMAZÔNIA E DEFESA NACIONAL / Organizador Celso Castro - Rio de Janeiro: Editora FGV, 2006

AMIGOS DA TERRA: Amazônia Brasileira. Debate sobre as políticas públicas para Amazônia na Imprensa Brasileira. Publicado pela ONG: Amigos da Terra desde 1998

ANDRADE, de, A. S. ONG' s e Desenvolvimento Regional em Rondônia. 2001. 2v. 141p. Dissertação (Mestrado em Antropologia). Universidade Federal de Pernambuco, Recife.

ARROYO, Mónica. A internacionalização do externo no ambiente dos negócios: novos elementos da dinâmica territorial in CASTELO, lara Regina et ali (orgs.). Fronteiras na América Latina: espaços em transformação. Porto Alegre: Ed. Universidade, UFRGS, Fundação de Economia e Estatística, 1997

BACKHEUSER, E. Das politische Conglomerat Brasilien, ZfG, pág. 625-630, Berlin, 1926

BAINES, S. G. Os índios Makuxi e Wapixanas e suas relações com estados nacionais na fronteira Brasil-Guiana. Série Antropologia nํ338. UnB, Brasília, 2003

BARBOSA, Altiva Do povo sem espaço ao espaço sem povo: uma análise da Zeitschrift für Geopolitik, durante a República de Weimar. Mestrado defendido na FFLCH-USP, São Paulo, 1996

BARBOSA, Reinaldo Imbrozio (ed.). Roraima: Bibliografias Úteis à Pesquisa Científica (1641-1998). INPA, Manaus, 2000

BARBOSA, Reinaldo Imbrozio. Ocupação Humana em Roraima. I. Do Histórico Colonial ao Início do Assentamento Dirigido. Boletim do Museu Paraense Emilio Goeldi, 9 (1): 123144. Belém, 1993-1

BARRETO, Mônica Mazzer (2006). Waves in the Forest. Department of Social Policy London School of Economics and Political Science University of London August, 2006

BARROS, A.C. 2001. Sustentabilidade e Democracia para as políticas públicas na Amazônia. Cadernos Temáticos n.8- Brasil Sustentável e Democrático: FASE/IPAM. 128p. Livro. IPAM

BARROS, Nilson Crócia de - Roraima: paisagens e tempo na Amazônia Setentrional. Ed. Universitária/UFPE, Recife, 1995 
BECKER, Bertha Competitividade com Equidade e Sustentabilidade: construção das políticas de integração nacional e desenvolvimento regional. Rio de Janeiro, BNDES, 2000.

BECKER, Bertha. "A geografia e o resgate da geopolítica". In: RBG, Ano 50, Número Especial, Tomo 2, IBGE. Rio de Janeiro, 1988

BECKER, Bertha. Novos rumos da política regional: por um desenvolvimento sustentável da fronteira amazônica In: BECKER e MIRANDA, M. A Geografia Política do desenvolvimento sustentável, Ed. UFRJ, Rio de Janeiro, 1997.

BECKER, Bertha. Amazônia: Geopolítica na virada do III milênio. Rio de Janeiro, Garamond, 2004

BRASIL. Constituição da República Federativa do Brasil. 16 Edição. Ed. Saraiva, São Paulo, 1997

BRASIL. Secretaria Geral. Conselho de Segurança Nacional. Desenvolvimento e segurança na região ao norte das Calhas dos rios Solimões e Amazonas: Projeto Calha Norte. Brasilia, 1985

BRASIL. Ministério do Meio ambiente. Causas e dinâmica do desmatamento na Amazônia. MMA. Brasília, 2001

BRASIL. Ministério do Meio ambiente. Política Nacional Integrada para a Amazônia Legal. MMA/SCA, Brasília, 1995

CANO, Javier Sánchez. Da Segurança Cooperativa à Segurança Ecológica. Revista Ecologia Política. V. 15, 1998.

CAPEL, Horacio. Filosofía y ciencia en la geografía contemporánea. Segunda edição, 510 p., ed. Barcanova, Barcelona. 1983

CARDOSO de OLIVEIRA, Luís Roberto. Pesquisa em versus Pesquisas com seres humanos. In. VÍCTORA, Ceres, OLIVEN, Ruben G., MACIEL, Maria E. e ORO, Ari Pedro (Orgs.). Antropologia e Ética: o debate atual no Brasil. Niterói: Ed.UFF, 2004. p.33-44

CARDOSO DE OLIVEIRA, Roberto. "Ação indigenista, etinicidade e o diálogo interétnico". Estudos Avançados ํo 14 (40) (213-230), São Paulo, 2000

CARNEIRO da CUNHA, Manuela. Antropologia do Brasil: mito, história, etnicidade. São Paulo: Brasiliense, 1987. p.113-119

CARVALHO, Delgado \& CASTRO, Teresinha. "Geografia Política e Geopolítica". Boletim Geográfico, ㄲ133, Rio de Janeiro, 1956

CASTRO, Celso (org.) AMAZONIA e Defesa Nacional, Ed. FGV, RJ. 2006

CASTRO, Terezinha de. Brasil: a dimensão estratégica da potência regional. Carta Internacional, Funag-USP, ano VII, no 80, outubro, São Paulo, 1999.

CAVAGNARI, Geraldo Lesbat. Defesa com democracia e desenvolvimento. Teoria e Debate, $\mathrm{n}^{\circ} 24,1994$

CIDR- Centro de Informação da Diocese de Roraima. Índios de Roraima. Coleção Histórico-Antropológica ํㅜ 1. Boa Vista, 1989. 
COMISSÃO PRÓ-YANOMAMI. Yanomami pedem ao Exército que proteja a Terra Indígena Yanomami - www.proyanomami.org.br 20/05/2005

COMISSION ON GLOBAL GOVERNANCE: Our Global Neighbourdhood. Oxford University Press, 1995.

COSTA, BECKER, MORAES, E GLER, DAVIDOVICH et alli. Os Ecossistemas Brasileiros e os Principais Macrovetores de Desenvolvimento". MMA, Brasília, 1995

COSTA, Wanderley M. - Geografia Política e Geopolítica. Tese de Doutorado do Departamento de Geografia da Universidade de São Paulo, Hucitec-Edusp, São Paulo. (1992)

COSTA, Wanderley Messias. Les politiques territoriales brésiliennes dans le contexte de l'intégration sud-américaine. In: Revista: D’Amérique Latine nº 46/47. Institut Européen de Géoéconomie. Paris, 2002

COSTA, W.M. \& MORAES, A C R. Geografia Crítica - a valorização do espaço. $3^{\underline{a}}$ ed. São Paulo, Hucitec, 1993

COUTO E SILVA, Golbery. Conjuntura Política Nacional, O Poder Executivo \& Geopolítica do Brasil. Rio de Janeiro: José Olympio Editora, 1981.

COY, Martin \& NEUBURGER, Marina - "As fronteiras pioneiras na Amazônia brasileira entre globalização e sustentabilidade". In: CEHU - I Encontro Internacional Humboldt, Buenos Aires, 1999

CUNHA, M.C. da. Nativ Realpolitik. Nacla: Report in the Américas. Vol. XXIII $n^{\circ}=1$, maio, 1989

DOMÍNGUEZ, Jorge e outros. Conflictos territoriales y democracia en América Latina. Buenos Aires: FLACSO, 2003.

EIA - Estudo de Impacto Ambiental da empresa Ouro Verde Agrosilvopastoril, STCP Engenharia de projetos Ltda, 2001

ESTADO DE SÃO PAULO. Interesses corporativos influem no efetivo. Edição Especial Militar. www.estado.com.br. Copyright 1999

FARAGE, Nádia. As Muralhas dos Sertões: os povos indígenas no rio Branco e a colonização. Ed. Paz e Terra, ANPOCS, Rio de Janeiro, 1991

FAORO, Raymundo. Os donos do poder: formação do patronato político brasileiro. 2. ed. Revisada e aumentada. Porto Alegre, Globo; São Paulo Edusp, vol.1, 1975

FAORO, Raymundo. Os donos do poder: formação do patronato político brasileiro. 5. ed. Porto Alegre, Globo, vol.2, 1979

FIGUEIREDO, Adma H. - A Divisão da Floresta: Uma (re) interpretação do mapa político da Amazônia Brasileira - Tese de Doutorado do Departamento de Geografia da UFRJ, 1998

FLORES, Mário César. Reflexões estratégicas: repensando a defesa nacional. São Paulo: Ed. Realizações, 2003.

FORESTA, R. 1992. Amazônia and the politics of geopolitics. The Geographical Review 82(2): 128-142. 
FRANKLIN, Cléber Batalha. Apreciación Geopolítica de la frontera Brasil - Venezuela. Dissertação de mestrado em Ciências Políticas da Unversidad de los Andes, FCJP/CEPSAL. Mérida. Venezuela, 1996

FREITAS, Aimberê. A história política e administrativa de Roraima: 1943-1985. Ed. Calderaro. Manaus, 1993.

FREITAS, Aimberê. Geografia e História de Roraima. 5르 Ed. rev. atual. . Ed. Belverede, Manaus, 1997

FREITAS, Edinaldo B. Índios-Soldados: A GRIN e a tradição militar da política indigenista brasileira. Tese de Doutorado em História Social, FFLCH/USP, SP, 1999

FUNDAÇÃO DO MEIO AMBIENTE E TECNOLOGIA DE RORAIMA / FMATR - Roraima O Brasil do hemisfério Norte. Diagnóstico Científico e Tecnológico para o Desenvolvimento. Tércio. S. A. Jr., Roraima, 1993

FURLEY, P. et allii. The Forest frontier: setlement and change in Brazilian. Roraima. Routledge, London, 1994

GARRISON, John. From confrontation to collaboration: civil society-government-World Bank relations in Brazil. Washington: The World Bank, 1999

GEOFFREY D. Dabelko The Environment and Conflict in the Third World: Examining Linkage, Context and Policy Occasional Paper No. 12 Harrison Program on the Future Global Agenda January 1996

GIDDENS, Anthony. O Estado-Nação e a Violência: Segundo Volume de Uma Crítica Contemporânea ao Materialismo Histórico. Tradução de Beatriz Guimarães. São Paulo: USP, 2001.

GOVERNO DO ESTADO DE RORAIMA - Diagnóstico do Estado de Roraima. ITERAIMA, Roraima, 2005

GOVERNO DO ESTADO DE RORAIMA. Indicadores Econômicos de Crescimento e Desenvolvimento do estado de Roraima. Seplan: Boa Vista, 2006.

GOVERNO DO ESTADO DE RORAIMA. Perfil Sócio-Econômico de Roraima. Secretaria de Estado de Planejamento e Orçamento. Boa Vista, 2003.

GUIDENS, A . The Consequences of Modernity. Cambridge University Press, 1990

GUIDENS, A, Beyond Left and Right. The Future of Radical Politics. London, Cambridge University Press, 1994

GUILHON ALBUQUERQUE, J. (org.) Diplomacia para o Desenvolvimento. Sessenta Anos de Política Externa Brasileira, 1930-1990. São Paulo, EDUSP, SP, 1996

GUIMARAES, R. Ecopolitics in the Third World: an Institutional Analysis of Environmental Management in Brazil. Boulder, Westview Press, 1991

HEMMING,J. How Brazil acquired Roraima. Hispanic American Historical Review 70:2. Duke University Press, 1990

HEMMING,J. Settlement in Northern Amazonia: The case of Roraima. Royal Geographical Society. London, 1992 
HOFFMANN, Maria (Orgs.). Etnodesenvolvimento e políticas públicas: bases para uma nova política indigenista. Contra Capa Livraria/LACED, Rio de Janeiro 2002

HUNTINGTON, Samuel P. O Soldado e o Estado: Teoria e Política das Relações entre Civis e Militares. Rio de Janeiro: Biblioteca do Exército, 1996.

JAGUARIBE, Hélio. Defesa nacional: desafios e possíveis respostas do Brasil. Atualização do pensamento brasileira em matéria de defesa e segurança. Banco de dados. Disponível em defesa.gov.br em 21/10/2004

JORNAL DO BRASIL. Amazônia: miséria preocupa Exército - 06/03/2005 Rio de Janeiro

KEOHANE, R and Ostrom, E. (eds.) Local commons and global interdependence: heterogeneity and cooperation in two domains. London: Sage Publications, 1995

KLEINSCHMAGER, R. Géographie et Idéologie Entre Deux Guerres: La Zeitschrift für Geopolitik 1924-1944. L'Espace Geographique, n¹. Paris, 1988

KITAMURA, Paulo C. Desenvolvimento sustentável: uma abordagem para as questões ambientais da Amazônia. Campinas,1994. Tese (Doutorado)- Universidade Estadual de Campinas, 1994.

KOST, K. Die Einflusse der Geopolitik auf Forschung und Theorie der Politischen Geographie von ihren Anfangen bis 1945. Tese de doutorado do Instituto de Geografia da Universidade de Bonn, no 76, Bonn, 1988.

LAFER, Celso. A identidade internacional do Brasil e a política externa brasileira Passado, presente e futuro. São Paulo: Perspectiva, 2001.

LAGET/UFRJ - Laboratório de Gestão do Território. Detalhamento da Metodologia para Execução do ZEE na Amazônia. BECKER, B. e EGLER, C. (Coords..) SAE/MMA (Secretaria de Assuntos Estratégicos /Ministério do Meio Ambiente), 1996

LEINER, Piero de Camargo. O Exército e a questão amazônica. Estudos Históricos, Rio de Janeiro: FGV, n०15, 1995

LEINER, Piero de Camargo. Meia volta volver: um estudo antropológico sobre a hierarquia militar. Rio de Janeiro; FGV/Fapesp, 1997

LEINER, Piero de Camargo. O sistema da guerra: uma leitura antropológica dos exércitos modernos. 2001 Tese de Doutorado em Antropologia da USP, São Paulo, 2001

LEITE, Rogério Cerqueira O SIVAM: uma oportunidade perdida Estudos Avançados no 46, págs. 123-130 - USP/Instituto de Estudos Avançados/IEA - vol. 1, № 1 SP 1987

LÉNA, Philippe \& OLIVEIRA, A. E. (orgs) Amazônia: A Fronteira Agrícola 20 anos depois. Museu Paraense Emílio Goeldi: Pará, 1991

LOURENÇÃO, Humberto. A defesa Nacional e a Amazônia: o SIVAM. Dissertação de mestrado em Ciência Política. Instituto de Filosofia e Ciências Humanas, Unicamp. São Paulo, 2003

MACHADO, L.O. - A Geopolítica do Governo Local: proposta de abordagem aos novos territórios urbanos da Amazônia - Anais do $3^{\circ}$ Simpósio Nacional de Geografia Urbana, Rio de Janeiro, 1993

MACHADO, Matheus Um ministério para a Amazônia - Correio Braziliense 08/04/2005 Brasília, DF, 2005 
MacMILLAN,G. Gold Mining and Land-Use Change in Brazilian Amazon. Tese da University of Edinburg, 1993

MAGNOLI, Demétrio - O corpo da pátria - imaginação geográfica e política externa do Brasil (1808-1912), São Paulo, Unesp/Moderna, 1997

MARTIN, André Roberto. Fronteiras e Nações. 4. ed. Coleção Repensando a Geografia. São Paulo: Contexto, 1998.

MATTOS, Carlos de Meira. A geopolítica e as projeções de poder. Rio de Janeiro: Biblioteca do Exército, 1977.

MATTOS, Carlos de Meira. Geopolítica e modernidade: a geopolítica brasileira. Rio de Janeiro: Biblioteca do Exército Editora, 2002.

MATTOS, L.; Moutinho, P. \& Alencar, A.. Controvérsias e Consensos sobre as Obras de Infra-Estrutura na Amazônia Brasileira: Uma Abordagem Social e Ambiental. Revista do Encontro Nacional da Rede Brasil, IPAM, Belém, 2001

MEDEIROS F., Oscar. Cenários geopolíticos e emprego das Forças Armadas na América do Sul. Dissertação de Mestrado do Departamento de Geografia/USP, São Paulo, 2004

MEIRELLES, Denise Maldi - Os guardiões de fronteira. Cuiabá. Petrópolis. Vozes, 1989

MELLO, C. F.P. Os corpos de auxiliares e de ordenanças na segunda metade do século XVIII: as capitanias do Rio de Janeiro, São Paulo e Minas Gerais e a manutenção do Império português no centro-sul da América. Tese de Doutorado em História da UFF, Niterói, 2002a

MELLO, L. A Geopolítica do Brasil e a Bacia do Prata, Tese, São Paulo, 1981

MELLO, N A. Políticas Públicas Territoriais na Amazônia Brasileira: conflitos entre conservação ambiental e desenvolvimento 1970 - 2000. Tese de doutorado do Departamento de Geografia-USP. São Paulo, 2002b

MINISTÉRIO DA DEFESA, PCN, FGV/ISAE - Plano de Desenvolvimento Local, Integrado e Sustentável/PDLIS dos Municípios de Roraima para os anos de 2001-2004, (2000)

MIYAMOTO,Shiguenoli. A Política de Defesa Brasileira e a Segurança Regional. Campinas. Instituto de Filosofia e Ciências Humanas, n91, UNICAMP, SP, 2000

MIYAMOTO, S Amazônia, militares e fronteiras. Antropologia e Indigenismo . Rio de Janeiro: Museu Nacional/UFRJ, n. 1, p.49-59, 1990.

MIYAMOTO,Shiguenoli. O pensamento geopolítico brasileiro (1920-1980). Tese de doutorado do Departamento de Ciências Sociais da USP, São Paulo, 1981.

MONTANARI JUNIOR, Isaias. Demarcação de terras indígenas na faixa de fronteira sob o enfoque da defesa nacional. Dissertação de mestrado em Direito da UFSC. Florianópolis, 2005

MORAES, Antonio Carlos R. Bases da Formação Territorial do Brasil, São Paulo, ed. HUCITEC, 1999

MORAIS, Antonio C. R. e FERNANDES, Florestan. (Org.) Ratzel. Ed. Ática, São Paulo, 1990 
MORGENTHAU, Hans J. A Política entre as nações - A luta pelo poder e pela paz. Traduzida por Oswaldo Biato da edição revisado por Kenneth W. Thompson. Prefácio de Ronaldo M. Sardenberg. Brasilia: UNB, 2003.

MOURÃO, Gersa M. N. Colonización reciente y asentamientos rurales em el sureste de Roraima. Amazônia entre la política y la naturaleza. Tese de doutorado do Departamento de Geografia da Universidade de Valladoulid, Espanha, 2003

NASCIMENTO, Izaura Rodrigues do. A estadualização das políticas ambientais no Amazonas - Programa de Pós-Graduação Ciências Ambientais e Sustentabilidade na Amazônia - Manaus, Amazonas, 2000

NEPSTAD, D. \& Ramakrishna, K. O mundo de olho na Amazônia. Em: Sustentabilidade e Democracia para as políticas públicas na Amazônia. Cadernos Temáticos n.8- Brasil Sustentável e Democrático. A.C. Barros ed. FASE/IPAM. 128p.IPAM, Pará, 2001

NITSCH, Manfed O futuro da Amazônia: questões críticas, cenários críticos Estudos Avançados no 46, págs. 141-156 - USP/Instituto de Estudos Avançados/IEA - vol. 1, № 1 SP 1987

OLIVEIRA, A.E. Amazônia: modificações sociais e culturais decorrentes do processo de ocupação humana (séc. XVII ao XX). Boletim do Museu Paraense Emílio Goeldi. Belém, 4(1): 65-115, julho de 1988

OLIVEIRA, E. R. Democracia e Defesa Nacional. A criação do Ministério da Defesa na presidência de FHC, Ed. Manole. São Paulo, 2005

OLIVEIRA, José Aldemir e Pe. GUIDOTTI, Humberto (org.). A igreja arma sua tenda na Amazônia. Editora da Universidade do Amazonas/EDUA. Manaus. 2000

OLIVEIRA, José Aldemir. Cidades na Selva. Editora Valer. Manaus. 2000

OSSENBRUGGE, J. Politische Geographie als raumliche Konfliktforchung. Tese do Instituto de Geografia da Universidade de Hamburg, no 40, Hamburg, 1983

OSTERUD, Oyvind "The Uses and Abuses of Geopolitics". Journal of Peace Research, vol.25, no2, p.192-199, Norwegian University Press, 1988

PAVAN, Crodowaldo (org.) Uma estratégias Latino-americana para a Amazônia. Vol. 2, e 3. Brasília. MMA Ed. Memorial e Unesp, São Paulo, 1996

PINTO, Lúcio Flávio Três reflexões sobre segurança nacional na Amazônia: Estudos Avançados no 46, págs. 131-140 - USP/Instituto de Estudos Avançados/IEA - vol. 1, № 1 SP 1987

PRESIDÊNCIA DA REPÚBLICA. BRASIL EM AÇÃO: Investimentos para o desenvolvimento, Brasília, 1996

PROJETO CALHA NORTE. Comitê interdisciplinar de Estudos sobre o Projeto Calha Norte. Documento linterno. Mimeo. 1987

RAFFESTIN, Claude Por uma Geografia do poder. 1a ed. 1980, tradução de Cecília França, ed. Ática, 269 p., São Paulo.,1993

REIS, Arthur Cezar Ferreira. A Amazônia e a cobiça internacional. 2 ${ }^{\underline{a}}$ Ed. Edinova Limitada, Rio de Janeiro, 1965

REIS, Arthur Cezar Ferreira. História do Amazonas. 2ª Ed.. Rio de Janeiro. Itatiaia, 1989 
REPETTO, Maxim. Roteiro de uma etnografia colaborativa: as organizações indígenas e a construção de uma educação diferenciada em Roraima, Brasil. Tese de doutorado em Antropologia Social da UnB. Brasília, 2002

RIBEIRO COSTA, Wagner. A Ordem Ambiental Internacional. São Paulo: Contexto, 2001

RODRIGUES, France. Garimpando a sociedade roraimense. Tese de Doutorado do NAEA/PA, 1996

RÖSSLER, M. Wissenschaft und Lebensraum. Tese do Instituto de Geografia da Universidade de Hamburg, 1990

RUDZIT, G. Segurança Nacional e Segurança Cooperativa no contexto brasileiro contemporâneo de Defesa. Tese do Departamento de Ciência Política da FFLCH/USP, São Paulo, 2003

SACHS, I. \& MENDES, A D. A inserção da Amazônia no Mundo. In: Amazônia 21. Uma Agenda para um Mundo Sustentável. Brasília. Conferência Internacional. Anais. 1998.

SANDNER, Gerhard "Mitteleuropa als Kultur-Landschaft". In: Ein Gespenst geht um:... Mitteleuropa, H.-A.Steger/R.Morell (org.), Ed. Theo Eberhard, Munique, 1987

SANTILLI, P. Pemongon Patá: Território Macuxi, rotas de conflito. Editora Unesp. São Paulo, 2001

SANTOS, Haroldo Amoras dos. O Dilema de Roraima: terra de índios e minérios. Boa Vista:IEL/FIER/DAMPI, 1993.

SANTOS, M. A Natureza do Espaço. 3를 Ed. São Paulo, Hucitec, 1999

SANTOS, Nélvio Paulo Dutra - Políticas Públicas, Economia e Poder: o Estado de Roraima entre 1970 e 2000. Tese. Núcleo de Altos Estudos da Amazônia/NAEA/UFPA, Belém, 2004

SCHMACHER, R. "Zur Theorie der Raumstrategie", ZfG (Revista de Gepolítica), Alemanha, 1934.

SCHÖLLER, Peter "Wege und Irrwege der Politischen Geographie und Geopolitik". In: Politische Geographie. J.Matznetter (org.), p.249-302, Ed. Wissenschaftliche Buchgesellchaft, Darmstadt, 1957.

SCHÖLLER, Peter. "Die Geopolitik im Weltbild des Historischen Materialismus". Erdkunde, vol.XIII, Lfg.2, p.88-98, Bonn, 1959.

SCHÖLLER, Peter. "Geopolitische Versuchungen bei der Interpretation der Beziehungen zwischen Raum und Geschichte". In: Geographie in der Geschichte, Denecke,D. e Fehn,K. (org.), caderno 96, ed. Franz Steiner, Stuttgart, 1989.

SEGATO, Rita Laura. Uma agenda de ações afirmativas para as mulheres indígenas do Brasil. UnB: Série Antropologia, n.329, 2003.

SILVA JR. Tércio Araújo (coord.). Roraima, o Brasil do Hemisfério Norte. Diagnóstico científico e tecnológico para o desenvolvimento. AMBTEC, Roraima, 1994

SILVA, Marcelle Ivie da Costa. Amazônia e política de defesa no Brasil (1985-2002). Dissertação de Mestrado, Instituto de Filosofia e Ciências Humanas. Unicamp, São Paulo 2004 
SILVA, Paulo R. Freitas. Dinâmica terrritorial urbana do Estado de Roraima - Brasil. Tese do Departamento de Geografia da FFLCH/USP, SP, 2007

SILVEIRA, Maria Laura. Um país, uma região: fim de século e modernidades na Argentina. FAPESP; LABOPLAN-USP, São Paulo, 1999

SOUZA LIMA, Antonio Carlos de e BARROSO-HOFFMANN, Maria. Além da tutela: aspectos de uma nova regulação dos direitos indígenas no Brasil. In. SOUZA LIMA, Antonio Carlos de e BARROSO-HOFFMANN, Maria (Orgs.). Além da tutela: bases para uma nova política indígena III. Rio de Janeiro: Contra Capa Livraria/ LACED, 2002

SOUZA, Carla M. de. Gaúchos em Roraima. Porto Alegre. Coleção História 42. EDIPUCRS, 2001

SOUZA, Valdir Aparecido de (Des)ordem na fronteira: ocupação militar e conflitos sociais na bacia do Madeira-Guaporé (30/40). Mestrado em História da UNESP, SP, 2002

STTUDART, Gen. Palestra proferida na Semana de Geografia. 22/Setembro/2004

SUDAM DRH / PNUD. Diagnóstico e cenarização macrossocial da Amazônia Legal: cenários sociais para a Amazônia Legal 2000/2010. Belém: SUDAM, 2001

THÉRY, HERVÉ (org.) - Environment et Dévelopement en Amazonie Brésilienne, Belin, Paris, 1997

TRAVASSOS, M. Projeção Continental do Brasil, 4ํㅡ. Ed. Ed. Nacional, São Paulo, 1947

VESENTINI, José William. Novas geopolíticas. 2a ed. São Paulo: Contexto, 2003

VIEIRA, Jaci G. Missionários, fazendeiros e índios em Roraima: a disputa pela terra 1777 a 1980. Tese do Programa de pós-graduação em História da Universidade Federal de Pernambuco, Recife, 2003

WOOD, C.H. The Military and the environment in the Brazilian Amazon. Journal of Political and Military Sociology, 21,1. 1993

WORLD BANK. Amazônia sustentável: limitantes e oportunidades para o desenvolvimento rural. Imazon. Belém, 2000

WORLD BANK. Toward an environment strategy for the World Bank Group. Progress Report. Washington, 2000 
ANEXOS 


\section{ANEXO 1}

\section{PORTARIA № 020 - EME, DE 2 DE ABRIL DE 2003}

Aprova a Diretriz para o relacionamento do Exército Brasileiro com as comunidades indígenas.

O CHEFE DO ESTADO-MAIOR DO EXÉRCITO, no uso da competência que Ihe confere 0 art. 117, da Portaria n- 041, de 18 de fevereiro de 2002 (IG 10-42), resolve:

Art. 1․ Aprovar a Diretriz para o relacionamento do Exército Brasileiro com as comunidades indígenas.

Art. 2ㅇ Os Órgãos de Direção Setorial, os Comandos Militares de Área e os demais Órgãos envolvidos adotem, em seus setores de competência, as providências decorrentes. publicação.

Art. 3으 Estabelecer que esta Portaria entre em vigor na data de sua AS COMUNIDADES INDÍGENAS

DIRETRIZ PARA O RELACIONAMENTO DO EXÉRCITO BRASILEIRO COM

\section{FINALIDADE}

Orientar as atividades a serem desenvolvidas e os procedimentos adotados pelo Exército Brasileiro (EB) no relacionamento com as comunidades indígenas.

\section{REFERÊNCIAS}

- Constituição Federal (1988);

- Lei no 6001, de 19 de dezembro de 1973- Estatuto do Índio;

- Decreto Presidencial não numerado, de 22 de agosto de 2002, que criou o Parque Nacional Montanhas do Tumucumaque, no Estado do Amapá, e dá outras providências;

- Decreto n-4.411, de 7 de outubro de 2002, que dispõe sobre a atuação das Forças Armadas e da Polícia Federal nas unidades de conservação e dá outras providências;

- Decreto n-4.412, de 7 de outubro de 2002, que dispõe sobre a atuação das Forças Armadas e da Polícia Federal nas terras indígenas e dá outras providências; e

- Diretrizes Gerais do Comandante do Exército - 2003.

\section{PREMISSAS BÁSICAS}

a. O Exército Brasileiro reconhece os direitos dos índios e mantém, historicamente, um excelente relacionamento com as comunidades indígenas, tendo o Marechal Rondon como paradigma desse relacionamento.

b. É de interesse da Força Terrestre manter um estreito relacionamento com as comunidades indígenas em todo o território nacional, particularmente na Amazônia, para complementar a estratégia da presença na região. 
c. A cooperação mútua com as comunidades indígenas precede à formação do Exército Brasileiro. Brancos, negros e índios lutaram juntos em Guararapes pela libertação da terra, pela primeira vez identificada como Pátria.

\section{ORIENTAÇÃO GERAL}

a. É fundamental que todos os escalões da Força Terrestre compreendam que os índios são nativos da terra e que lhes são reconhecidos os costumes, sua organização social, a língua, as crenças e as tradições, além dos direitos originários sobre as terras que, tradicionalmente, ocupam. Cabe à União demarcá-las, protegê-las e fazer respeitar todos os seus bens, podendo o Exército Brasileiro sempre que possível, cooperar com a demarcação e estudar formas de participação e apoio destinadas a melhorar a sobrevivência e as condições de vida das comunidades indígenas.

b. É importante que todos os militares, especialmente aqueles que terão contato direto com as comunidades indígenas, conheçam e respeitem os hábitos, os costumes e as tradições, de forma a tornar harmônica e proveitosa para a Força Terrestre a convivência com os indígenas em o todo território nacional.

c. Por conhecer melhor a região onde vive e estar a ela perfeitamente adaptado, o índio pode constituir-se em um valioso aliado na obtenção de dados sobre a região, nas operações e nas ações rotineiras da tropa.

\section{ATRIBUIÇÕES PRINCIPAIS}

\section{a. Estado-Maior do Exército (EME)}

1) Coordenar as atividades dos órgãos de direção setorial e dos comandos militares de área que envolvam o relacionamento do Exército Brasileiro com as comunidades indígenas.

2) Acompanhar as ações e emitir pareceres referentes à atividade da Força Terrestre relacionada ao assunto.

3) Considerar, quando do estudo de instalação ou transferência de unidades para as Terras Indígenas ou áreas próximas, o constante da Política de Gestão Ambiental do Exército (PGAEB) e da Diretriz Estratégica de Gestão Ambiental (DEGAEB), visando a neutralizar ou minorar o impacto sócio-ambiental que tais instalações podem causar.

4) Após a definição dos locais para a instalação de Organização Militar(OM) em Terras Indígenas ou próximas delas, informar às comunidades indígenas, bem como suas instâncias representativas.

\section{b. Comando de Operacões Terrestres (COTER)}

Incluir, no Programa de Instrução Militar, orientações para as OM localizadas nas áreas onde exista populações indígenas, sobre o trato com a mesma, principalmente com aqueles ainda não totalmente integrados à comunidade.

\section{c. Departamento de Ensino e Pesquisa (DEP)}


1) Incluir nos currículos das Escolas de Formação e Aperfeiçoamento assuntos referentes à situação geral das comunidades indígenas no Brasil, à legislação e ao processo de demarcação e homologação das Terras Indígenas.

2) Incluir no currículo da Escola de Comando e Estado-Maior, assuntos referentes à política indigenista brasileira e suas interações com o direito humanitário e com a soberania nacional.

\section{d. Departamento de Engenharia de Construção (DEC)}

1) Quando solicitado, fornecer ao EME parecer da conveniência para a Força Terrestre, da demarcação de terras indígenas, sob a ótica patrimonial.

2) Quando da realização de obras ou serviços técnicos em áreas indígenas considerar as medidas necessárias para a minimização do impacto sócio-ambiental às comunidades indígenas.

\section{e. Departamento Geral do Pessoal (DGP)}

Estabelecer, quando conveniente para o EB, convênios com a FUNAI, visando a apoiar projetos de saúde para as populações indígenas, mediante utilização da Organização Militar de Saúde mais próxima.

\section{f. Secretaria de Tecnologia da Informação (STI)}

Quando da realização de serviços técnicos em Terras Indígenas considerar as medidas necessárias para a minimização do impacto sócio-ambiental às comunidades indígenas.

\section{g. Comandos Militares de Área (C Mil A)}

1) Estabelecer normas próprias de convivência, quando for o caso, com vistas a orientar a conduta de militares ao tratar com os silvícolas, considerando as características e diversidade de cada grupo indígena.

2) Programar estágios para todos os militares que possam vir a ter contato com as comunidades indígenas, sempre que possível, com a participação de antropólogos, representantes da FUNAI e de outras autoridades no assunto.

3) Quando da seleção para o serviço militar inicial, priorizar a incorporação de jovens oriundos das comunidades indígenas, desde que voluntários e aprovados no processo de seleção. 


\section{$\underline{\mathrm{ANEXO} 2}$}

\section{DECRETO № 4.412, DE 7 DE OUTUBRO DE 2002}

\section{Dispõe sobre a atuação das Forças Armadas e da Polícia Federal nas terras indígenas e dá outras providências.}

O PRESIDENTE DA REPÚBLICA, no uso da atribuição que lhe confere o art. 84, inciso IV, da Constituição, e tendo em vista o disposto na Lei oㅡ 6.001, de 19 de dezembro de 1973, no art. 15 da Lei Complementar no 97, de 9 de junho de 1999, e nos arts. 142 e 144, § 1, inciso III, da Constituição,

\section{DE C RET A :}

Art. 1 № exercício das atribuições constitucionais e legais das Forças Armadas e da Polícia Federal nas terras tradicionalmente ocupadas por indígenas estão compreendidas:

I - a liberdade de trânsito e acesso, por via aquática, aérea ou terrestre, de militares e policiais para a realização de deslocamentos, estacionamentos, patrulhamento, policiamento e demais operações ou atividades relacionadas à segurança e integridade do território nacional, à garantia da lei e da ordem e à segurança pública;

II - a instalação e manutenção de unidades militares e policiais, de equipamentos para fiscalização e apoio à navegação aérea e marítima, bem como das vias de acesso e demais medidas de infra-estrutura e logística necessárias;

fronteira.

III - a implantação de programas e projetos de controle e proteção da

Art. $2^{\circ}$ As Forças Armadas, por meio do Ministério da Defesa, e a Polícia Federal, por meio do Ministério da Justiça, deverão encaminhar previamente à SecretariaExecutiva do Conselho de Defesa Nacional plano de trabalho relativo à instalação de unidades militares e policiais, referidas no inciso II do art 1, com as especificações seguintes:

I - localização;

II - justificativa;

III - construções, com indicação da área a ser edificada;

IV - período, em se tratando de instalações temporárias;

$\mathrm{V}$ - contingente ou efetivo.

Parágrafo único. A Secretaria-Executiva do Conselho de Defesa Nacional poderá solicitar manifestação da Fundação Nacional do Índio - FUNAI acerca de eventuais impactos em relação às comunidades indígenas das localidades objeto das instalações militares ou policiais.

Art. $3^{\circ}$ As Forças Armadas e a Polícia Federal, quando da atuação em terras ocupadas por indígenas, adotarão, nos limites de suas competências e sem prejuízo das 
atribuições referidas no caput do art. 1, medidas de proteção da vida e do patrimônio do índio e de sua comunidade, de respeito aos usos, costumes e tradições indígenas e de superação de eventuais situações de conflito ou tensão envolvendo índios ou grupos indígenas.

Art. $4^{\circ}$ Este Decreto entra em vigor na data de sua publicação.

Brasília, 7 de outubro de 2002; 181ํ da Independência e 114º da República.

FERNANDO HENRIQUE CARDOSO

Geraldo Magela da Cruz Quintão

Paulo de Tarso Ramos Ribeiro

Alberto Mendes Cardoso 